\title{
TRANSURANIC CONTAMINATED WASTE CONTAINER CHARACTERIZATION AND DATA BASE
}

LAWRENCE LIVERMORE LABORATORY

MITER 


\title{
TRANSURANIC CONTAMINATED WASTE CONTAINER CHARACTERIZATION AND DATA BASE
}

\author{
Submitied io: \\ Mr. M. R. Eaton \\ Lawrence Livermore Loboratory \\ P.O. Box 808, 1-44́́ \\ Livermore, Colifornio 94550
}

Sutbmitted by:

B. G. Kniozewycz

May 1980 Revision!

Tera adVANCEO SERVICES CORPORATION

2150 Shattuck Avenue

Berkeley, Califomig $\$ 4704$

415.845 .5200

Berkeley. Colitornio

Dallas, Texos

Exthesco, Marvicno

Weshirigton. D.C

New Yerk, New Yerk

Cel Mar, Colito'nia

Bcion Rouge, Loulsionc 


\section{TABLE OF CONTENTS}

Section

PREFACE ................ i

EXECUTIVE SUMMARY . .............. I

1.0 INTRODUCTION ........................ 1.

1.1 Transuranic (TRU) Contaminated Wastes . . . . ..... 1-1

1.2 TRU Woste Management Program . . . . . . . . . . . 1-3

2.0 BACKGROUND. . . . . . . . . . . . . . . . 2.1

2.1 Source of TRU Contaminated Woste . . . . . . . . . 2-1

2.2 TFU Contaminated Waste Clossificotion . . . . . . . . . 2.8

2.3 TFiU Waste Forms. . . . . . . . . . . . . . . . 2-12

3.0 TRIJ YONTAMINATED WASTE CONTAINERS ....... 3. !

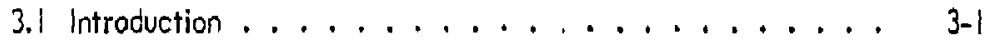

3.2 Regulatory Requirements ... . . . . . . . . . 3-2

3.3 Regulotions Designed to Ensure Adequate Contcinment

During Transportation . . . . . . . . . . 3-4

3.3.1 Type A Packaging . . . . . . . . . . . . 3-7

3.3.2 Type B Pockrging . . . . . . . . . . . . . 3-8

3.3.3 Proposet Thanges to Tronsportation Regulations . . . . 3-10

3.4 TRU Contaminured Woste Container Design . . . . . . . 3-10

4.0 TRU CONTAMINATED WASTE CONTAINER DATA BASE . . . . . 4-1

4.1 Waste Container Character istics and Description ..... . . 4-1

4.1.1 DOE Woste Contoiners. ............ 4-1

4.1.2 Commerciol TRU Woste Container ........ . 4-8

4.2 TRU Waste Container Specifications and Design Dota . . . . . 4-8

5.0 TRU CONTAMINATED WASTE CONTAINER CRITERIA . . . . 5- 5-

5.1 Waste Isolation Pilot Plant (WIPP) Woste-Acceptance Criterio , 5-1

5.2 Standard Containers for INEL TRU W'oste . . . . . . . 5-1

5.3 Mound TRU Woste Contoiner . . . . . . . . . . . . 5-5

5.3.1 Structural Design Developments . . . . . . . . 5-6

5.3.2 Design Life (Decomposition) . . . . . . . . . . . . 5-6́

5.3 .3 Materiols of Construction . . . . . . . . . . 5-6

5.3.4 Moximum Weight of Container and Contents . . . . . 5-7 


\section{TABLE OF CONTENTS}

(CONT.)

Section

Page

5.4 Suggested Waste Form and Pockage Criteria . . . . . . 5-9

5.4 .1 Woste Form Criteria . . . . . . . . . . . 5-9

5.4.2 Packoge Design Criteria . . . . . . . . . . . 5-10

6.0 REFERENCES . . . . . . . . . . . . . . . 6.1

APPENDIX A: GLOSSARY OF TERMS ANID DEFINITIONS

Glossary of Terms and Definitions. . . . . . . . . . . . A-I

Abbreviations .................. A.13

Symbols of the Elements. . . . . . . . . . . . . . . . . A. A.14

Factors for Converting Units to $\$ 1$ System Equivalents . . . . . . A A..16

APPENDIX B: TRANSURANIUM RADIONUCLIDES: AN OVERVIEW OF CHEMICAL, PHYSICAL AND RADIOLOGICAL PROPERTIES

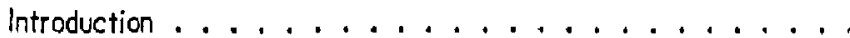

Physical Properties . . . . . . . . . . . . .

Chemicol Properties. . . . . . . . . . . . . . . . .

Criticulity Considerations . . . . . . . . . . . . . B B-16

APPENOIX C: WIPP ACCEPTANCE CRITERIA FOR DEFENSE LOW-LEVEL TRU WASTE

1.0 Introduction . . . . . . . . . . . . .

2.0 WIPP Acceptance Criteric for Defense Low-Level TRU Waste

3.0 Interim WIPP Acceptance Criteria . . . . . . . . . . .

4.0 Technical Support for GEIS - Volume 2: Commercial Waste Forms, Prackaging and Projection for Preconceptual

Fespository Design Studies . . . . . . . . . . . . . . .

APPENDIX D: TRU WASTE CONTAINER/GEOLOGIC MEDIA CORROSION STUDIES AND DATA BASE

1.0 Introduction . . . . . . . . . . . . . . .

2.0 Current DOE Canister Corrosion Programs and Results. . . . . D-6

APPENDIX E: MILD STEEL TRU WASTE CONTAINER CORROSION DUE TO INTEKACTION WITH DISPOSAL ENUVIRONMENT AND TRU WASTE FORM

1.0 Introduction $\ldots \ldots \ldots \ldots \ldots \ldots$ E-1

2.0 TRU Waste Container Corrosion in Soils ... . . . . . . E-2

3.0 Mild Steel Container Corrosion Due to TRU Waste

Form Interactions. . . . . . . . . . . . . E E-22 


\section{TABLE OF CONTENTS}

(CONT.)

Section

APPENDIX F: PROPOSED RECULATORY CHANGES: REQUIREMENTS FOR TRANSPORTATION OF RADIOACTIVE MATERIALS

1.0 International Regulatory Aspects ............ F- F-1

2.0 U.S. Regulatory Aspects . . . . . . . . . . . . . . F-5

3.0 Other Issues and Problems .................... Fo

4.0 Present Status of DOT/NRC Rulemaking Activities . . . , , F-I2

References. ................ F-13

APPENDIX G: DEPARTMENT OF TRANSPORTATION RECULATIONS (EXCERPTS) PERTAINING TO TYPE A WASTE CONTAINERS

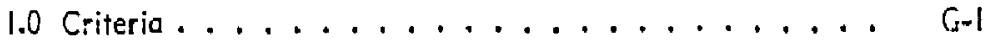

2.0173 .24 Standard Requirements For All Pockages. . . . . . . . G-2

$3.0173 .38 \%(j) \ldots \ldots$. . . . . . . . . . . . . . . . . . . . .

4.0 173.393 General Pockoging and Shipment Requirements . . . . G-7

$5.0173 .398(b) \ldots \ldots \ldots \ldots$ G-12 


\section{LIST OF TABLES}

Toble

Poge

I Results of Waste Container Survey of DOE Waste Cenerators . . . . 7

2 TRU Low-Level Waste Packoges in Use . . . . . . . . . . . . 10

3 TRU Woste Container Utilized by DOE Waste Generators . . . . . II

4 Defense Contact-itandled TRU Waste (Drum) . . . . . . . . . 13

5 Defense Contact-itandled TRU Waste (Box) . . . . . . . . . 14

6 Defense Remotely Handled TRU Woste . . . . . . . . . . . . 15

2-1 Cumulative Volume of DOE-Cenerated TRU-Contaminated Solid Woste Buried and/or Stored at DOE Sites . . . . . . . . . 2-3

2.2 DOE Focilities Generating TRU Contaminated Waste . . . . . . 2-4

2-3 Typical DOE TRU Contaminated Waste . . . . . . . . 2-5

2-4 Cumulative Waste Inventory at Commerciol Burial Sites. . . . . . 2-7

2-5 Cotegories of NRC Woste Disposal Clossification System . . . . . 2-11

2-6 Proposed Disposal Concentration Limits of TRU Rodioisotopes for Waste Classes $\left(u \mathrm{Ci} / \mathrm{cm}^{3}\right) \ldots \ldots$ 2-13

3-1 Type A and Type B Pockoge Quantity Limits . . . . . . . . . . 3-6́

3-2 Type B Packaging Permitted by DOT for Transport by 49 CFR 173.394

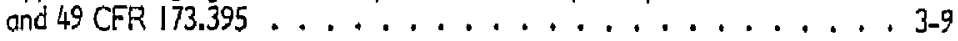

4-1 Results of Woste Container Survey of DOE Waste Generators . . . . . 4-2

4-2 DOE Waste Container Specificotions . . . . . . . . . . . . 4-4

4-3 TRU Low-Level Woste Pockages in L'se . . . . . . . . . . . . 4-5

4-4 Maximum Dimensions That Must be Considered for Waste Container Design. . . . . . . . . . . . . . 4-7

4-5 TRU Woste Contoiners Utilized by DOE Woste Generators . . . . . . . 4-9 


\section{LIST OF TABLES}

(CONT.)

Table

4-6 DOT Specification 68. . . . . . . . . . . . . 4-10

4-7 DoT Specification 6C . . . . . . . . . . . . 4-13

$4-8$, Dot Specification $6 \mathrm{~J}, \ldots \ldots$. . . . . . . . . . . . . 4-17

4-9 DOT Specificotion $6 \mathrm{~L} \ldots \ldots \ldots$. . . . . . . . . . . . 4-22

4-10 DOT Specificution $6 M \ldots \ldots \ldots \ldots$. . . . . . . . . . . . . . .

4-11 Requirements for DOT-7A Packoges . . . . . . . . . . . 4-29

4-12 DOT Specificotion 7A Steel Box . . . . . . . . . . . 4.30

4-13 DOT Specificotion 7A Steel Bin . . . . . . . . . . . . 4-33

4-14 DOT Specificotion 7A Steel Box . . . . . . . . . . . 4-36

4-15 DOT Specification 7A Concrete Vault. . . . . . . . . . . . 4-39

4-16 DOT Specification 7A Steel Drum . . . . . . . . . . . . 4-43

4-17 DOT Specification 7A Steel Drum . . . . . . . . . . . 4-46

4-18 DOT Specification 7A Shipping Container . . . . . . . . . . . 4-49

4-19 DOT Specification 7A Steel-Banded Wooden Shipping Container . . . 4-52

4-20 DOT Specification 7A (Fiberglass-Cooted Plywood Box) . . . . . . 4-59

4-21 DOT Specification I7C Steel Drum . . . . . . . . . . . 4-62

4-22 DOT Specification 17C . . . . . . . . . . . . 4-65

4-23 Dot Specification 17H Steel Drum . . . . . . . . . . . . 4668

4-24 DOT Specification 17H Steel Drum . . . . . . . . . . . . 4-71

4-25 DOT Specification 17H Steel Drum . . . . . . . . . . . 4-74

4-26 DOT Specification 15A - XXX Wooder Box . . . . . . . . 4-77

4-27 DOT Specification 15A - XXXX Wooden Box . . . . . . . . 4-81

4-28 DOT Specification 15A - 75 Wooden Box . . . . . . . . . . 4-84 


\section{LIST OF TABLES}

(CONT.)

Toble

4-29 DOT Specification 15A - 100 Wooden Box . . . . . . . . . 4-87

4-30 DOT Specificotion 19A - XXX Wooden Box . . . . . . . . . 4-90

4-31 DOT Specification 19.8-150 Wooden Box . . . . . . . . 4-93

4-32 DOT Specification 19B-150 Wooden Box. . . . . . . . . . 4-96

4-33 DOT Specification 198-75 Wooden Box . . . . . . . . . . . . 4-99

4-34 DOT Specification 2IC Fiberboard Drum . . . . . . . . . . 4-102

4-35 DOT Specification 42B 35-Gollon Aluminum Drum . . . . . 4-106

5-1 Deferse Contact-Handled TRU Waste (Orum) . . . . . . . . . 5-2

5-2 Defense Contact-Handled TRU Waste (Box) . . . . . . . . . 5-3

5-3 Defense Remotely Handled TRU Woste . . . . . . . . . . . 5-4 


\section{LIST OF FIGURES}

Figure

Page

I-1 TRU Waste Form Criteria Development Program . . . . . . . . 1-4

1-2 TRU Waste Form, Container and Porkage Criterio

Evaluation Methodology. . . . . . . . . . . . . 1-6

4-1 DOT Specification 6B Steel Drum (CFR49 178.98)

30 Gallons (114-Liters) .............. . 4-12

4-2 DOT Specification 6C Steel Urums (CFR49 178.99)

5 and 10 Gallon (19-Liter and 38-Liter) ........... 4-16

4-3 DOT Specification 6J Steel Drum (CFR 49 178.100)

55 Gallon (208-Liter) . . . . . . . . . . . 4-20

4-4 DOT Specification 6J Steel Drum (CFP 4: 178.100)

55 Gollon (208-Liter) . . . . . . . . . . . 4-21

4-5 DOT Specification . . . . . . . . . . . . . 4-24

4-6 DOT Specification 6M (CFR49 178.104) . . . . . . . . . . 4-27

4-7 DOT Specification 6M

Rocky Flats Model 1518. . . . . . . . . . . . . 4-28

4-8 DOT Specificotion 7A Steel Box (CFR49 178.350). . . . . . . . 4.32

4-9 DOT Specification 7A Steel Box (CFR49 178.350), . . . . . . . . . 4-35

4-10 DOT 5pecificotion 7A 5teel Box (CFR49 178.350). . . . . . . 4-38

4-!I DOT Specificotion 7A Concrete Voult (CFR49 178.350. . . . . . . 4-41

4-12 CJT Specification 7A Concrete Voult (CFR49 178.350) . . . . . 4-42

4-13 DOT Specificotion 7A Steul Drum (CFR49 178.350) . . . . . . 4-45

4-14 DOT Specification TA Steel Drum

(CFR49 178.350) - 4 gallon (l.IL). . . . . . . . . . . 4-48

4-15 DOT Specification 7A Shipping Container (CFR49 178.350) , . . . 4-51

4-16 DOT Specification 7A Steel-Eanded Wooden Shipping Container

N.L.O. Model G-4214 ............. . . 4-54 


\section{LIST OF FIGURES}

(CONT.)

Figure

Poge

4-17 DOT Specification 7A Steel-Banded Wooden Shipping Container

N.L.O. Model G-4245, . .............. 4-55

4-18 DOT Specification 7A Steel-Banded Wooden Shipping Container

N.L.O. Wodel G-4255 . . . . . . . . . . . 4-56

4-19 DOT Specification 7A Steel-Banded Wooden Shipping Contoiner

N.L.O. Model G-4273 . . . . . . . . . . . . . . . 4-57

4-20 DOT Specification 7A Steel-Bonded Wooden Shipping Container

N.L.O. Model G-4292, . . . . . . . . . . . . . . 4-58

4-21 DOT 7A Cleoted Plywood Box Assembly. . . . . . . . . . . . 4-60

4-22 DOT 7A Fiberglass-Cooted Plywood Box . . . . . . . . . 4-6́l

4-23 DOT Specification 17C Steel Drum

(CFR49 178.115) - 5 gallon $(1.3 L) \ldots \ldots$. . . . . . . . . . . .

4-24 DOT Specification 17C Steel Drum

(CFR49 178.115)- 55 gollon (208-L) , . . . . . . . 4-67

4-25 DOT Specification 17H Steel Drum

(CFR49 178.118) - 30 gallon $(114-1) \ldots . \ldots . \ldots 40$

4-26 DOT Specification 17H Steel Drum (30 gallon)

With 5-Gallon Polyethylene Carboy - (CFR49 178.118) . . . . . . 4-73

4-27 DOT Speciricotion 17H Steel Drum

(CFR49 178.1/8) - 55 gallon (208-L) . . . . . . . 4-76

4-28 DOT Specification I5A - XXX Wooden Box

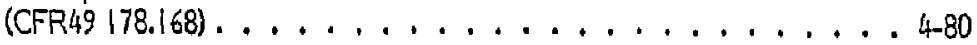

4-29 DOT Specification 15A - XXX Wooden Box

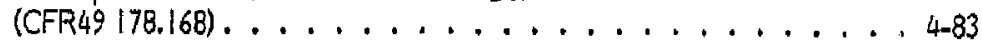

4-30 DOT Specificotion 15A-75 with Pipes/Screw Cops

115A - CFR49 178.168) ............... 4-86

4-31 DOT Specification 15A-100 Wooden Box

(CFR49 178.168) . . . . . . . . . . . . . 4-89

4-32 DOT Specification 19A - XXX Waaden Box

(CFR49 178.190) . . . . . . . . . . . . . 4-92

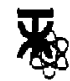




\section{LIST OF FIGURES}

(CONT.)

Figure

Page

4-33 DOT Srecification 198-150 Wooden Box

(CFR49 178.191) . . . . . . . . . . . . . . 4-95

4-34 DOT Specification 198-150 Wooden Box

(CFR49 178.191). . . . . . . . . . . . . 4 4-98

4-35 DOT Specification 15B-75 Wooden BCx

(CFR49178.191). . . . . . . . . . . . . . 4-101

4-36 DOT Specification 21C Fiberboard Drums

(CFR49 178.224) . . . . . . . . . . . . . 4-105

4-37 DOT Specification $42 B$ Aluminum Drum

(CFR49 178.107)-55 Gallon (28-L) . . . . . . . . . . . 4-108 


\section{PREFACE}

The Nuclear Regulatory Commission (ivRC) is developing regulations governing the management, handling and disposal of transuranium (TRU) radioisotope contaminated wastes as part of the NRC's overall waste management program. In the development of such regulations, numerous subtosks hove been identified which require completion before meaningful regulations can be proposed, their impact evaluated and the regulations implemented. This report was prepared by TERA Advanced Services Corporation to assist Lowrence Livermore Laborofory (LLL), prime controctor to the NRC, in the development of the technicol doto bose necessory to support rule-making octions dealing with TRU-contaminated wastes.

An earlier report, "Inventory and Sources of Tiansuranic Solid Waste," presented the waste sources, characteristics and inventory of both Department of Energy (DOE) generoted and commercially genercted TRU waste. In this report a wide variety of waste sources as well as a large TRU inventory were identified. In the report "Tronsuranic Contaminated Waste Form Charccterization and Data Base," the numerous woste scurces were defined in terms of their lodiologic, chemicol and physical form prior to disposol. The purpose of this report is to identify tha different packaging systems used and proposed for TRU woste and to document their charocteristics. This document then serves as port of the doto base necessary to complete preparation and initiate implementation of TRU waste container and packaging standards and criteria suitable for inclusion in the present TRU waste monagement program.

It is the pirpose of this report to serve as a working document which will be used as appropi iate in the TRU Waste Monagement Program. This report, and those following, will be compatible not only in formut, but also in reference material and direction. Comments, clarifications or improved data should be directed to B. G. kniozewycz ot TERA's Berke!ey office. 


\section{EXECUTIVE SUMMARY}

Until recently, radioactive waste manogement strotegies hove underestimated the significancu of the waste packoge by concentrating on the waste isolation (geologic) system. In the present tronsuranic (TRU) waste management program, an extensive dato base is being developed to identify TRU waste sources, and inventory waste forms and potential forms and the waste containers. This repcitt provides a data base for waste containers utilized or proposed for TRU contominateo waste. With this informotion a more systemotic evoluation of the waste package (waste, waste form and waste container) will be possible to ensure that all technological barrier designs to limit woste migration in geologic disposal sites are identified and evaluated.

Low-level radioactive waste containers, and those for TRU waste, evolved to fill a need os the need arose. Even with the creation of the Department of Transportation (DOT) in 1966, to regulate the radiocctive waste containers, at least 20 different waste containers have been or are being used to dispose of commercial and DOE-generated TRU waste.

Various criteria must be considered in the selection of a container for a variety of TRU waste materiols and pockage-related functions. In certain cases, the container may be used as a process vessel le.g., in solidifying wastes by using cements, urea-formaldehyde resins, bitumen or other similar materials). Container design is important in meeting the requirements for transportation of solidified waste packoges, interim handling, depository design for disposal and consideration for retrievability, if this is deemed necessary. The container should provide radiotion shielding, if required, and be of sufficient integrity to ninimize the probobility of conioiner breach due to handling or transportation accidents. The purpose of the container is to provide eose of handling and minimal personnel exposure, and to prevent loss of activity from the package prior to burial. The containe!'s may also provide a barrier to radionuclide release 
from the waste form in burial; though little credit hos been given to the container once the waste package is buried. This is the result of a lack of a proven long-lived engineered waste container design. Though these considerations moy be important for non-TRU low-level waste, the long holf-lives of some TRU radionuclides make such considerotions meoningless (except for woste retrievability considerations) over on extended time period. If retrievability is a requirement, the period of retrievability must be considered in the container design life.

Design guidance for waste containers is essentially limited to regulations published in 10CFR - Parts, 20, 70, 71 and 73, 49CFR - 173.391 through 173.395 (presently under revision), Regulatory Guide 7.4 "Leakoge Tests on Packoges for Shipment of Radioactive Materials;" Regulatory Guide 7.6 "Acceptable Structured Methods for Use in Designing Large Quantity Pockages;" Regulatory Guide 7.8 "Load Combinations for the Structural Analysis of Shipping Casks;" and, ANSSI N14.5 "Leokoge Tests on Pockoges for Shipping of Radioactive Mioterials." Other standards are under development by a N14 standords group sponsared by the American Insuronce Association concerned with various aspects of shipping rodiocctive moteriols.

The current DOE regulations concerning the handling of TRU contaminated dry wastes require pockaging and burial/storage in such a manner that the containers can be retrieved intact and contamination-free for a 20-year period.* This DOE requirement for a contamination-free storage period lafter which time the container will be shipped for disposal to a federal repository) establishes design criteric for material of construction and identifies the importance of ensuring waste form/waste contoiner compotibility. Also established are the requirements for additional handling during the tronsport to the repository, for subsequent handling, and for possible retrieval from the repository ot a later cate. With regard to hondling, the container design must consider the following:

\footnotetext{
* Presently proposed WIPP criterio only require a 10-year life. ${ }^{39}$
} 
- Damage to the contoiner

- Hiandling methods

- Rodiation dose to person.

- Transportation activities

- Storage-related activities

- Retrievability from interim storoge and possibly from the repository

- Contamination

- Repockaging of foiled contciners

Container integrity is the critical foctor for TRU waste centainers. Basically, three factors must be controlled:

- Internal container degradation

- External container degradation

- Container closure

Deterioration of the container, which occurs as a result of reactions with the contained wastes, must be limited to assure the survival of the waste container and packoge. Limiting deterioration can be accomplished by controlling detrimental interoctions between the wastes or their decomposition products and the total package (primary container plus liner or packcge coating). The processes that could couse deterioration include:

- Corrosion

- Radiolysis

- Pyrolysis

- Chemicol attack

- Biological interactions 
Due to the diverse materials in the waste matrix, assessment of potential interactions is complex; and the solutions ore currently uncertain. Appendix $E$ presents o detailed discussion of the limited data which have been identified.

Corrosion of the package from on internal source may be o major problem for some waste form types. If external moisture is prevented from entering the pockage, dry inert materials, such os some types of building debris and equipment, should require only structural strength and resistance to external corrosion in packaging to meet the requirement for interim storage, as well as during the retrieval period at the waste repository. Other waste materials, however, hove been shown to be incompatible with the containers which hove been previously used for storgge. At LASL, sludges from the liquid waste treatment plant hove acceleroted the internal corrosion of unprotected mildsteel drums to cause leakage within one year. Corrosion could also result from acid or other chemicals absorbed from the waste materiols.

Viveny internal corrosion problems could be elimingted, or at least moderated, by using some inner liner or chemical-resistont packog coating between the waste and the outer container. Several DOE sites employ some form of internal protection in on ottempt to limit corrosion of the primary container. An alternate solution migint be the use of a corrosion-resistant primary container, such as a polyethylene or fibergloss drum. Because of its potential combustijility, this type of container would probobly be restricted to uses involving roncombustible materials and might require a separate storage area from the combustible wastes. Alteration of corrosive wastes to a more inert form might be the most desirable solution, and indeed, ORNL has utilized stainless steel drums for certain TRU wastes.

The problem of interoction with the container is not limited to the wastes alone, but also encomposses the products of the degradation of these wastes. iviojor sources of decomposition include radiolysis and pyrolysis, though the extent of the potentiol problem from these processes cannot be fully assessed at this time. 
The products of radiolysis of materials (such os cellulosics, plastics, and water) are known; but the experiments were usually performed using gammo or neutron irradisiton. The effects of alpha radiotion, with its high energy and limited penetrability, on systems such os these hove not been well investigated.

The degree and rate of degradation of a packoging material will be dependent upun the material used, any auxiliary protection afforded by a protective coating, and the environment in the storoge iacility. Specifications selected for cny one of these three foctors moy decrease the need for limitation of the other two.

Selection of the actual packaging materiol must be carefully considered in relotion to the storage environment. For example, a wooden box in a damp environment may decompose rapidly, while the same box in a drier, controiled environment may lost for many years. On the other hand, if the environment of the box is too dry, cracking of the wood may occur. Similarly, an unprotected mild-steel drum will undergo rapid corrosion in a damp atmosphere. Unrelieved stress in the currently used steel drum has been shown to be an important foctor in the rote of corrosion of parts of this container. In this respect, any minor damage (such as denting of a steel container during handling, transport, or storage operations) may be significant to the survival of the pockage during the inter im storage period.

The tightness of the closure mechonism on a woste container is importont to the packoge integrity ouring handling and storoge of retrievul! 'e transuranic woste. Radiological health and sofety considerations during handling, transport, and storoge dictate containment of contamination. It is recognized that some containers are complex in design, with sealed inner containers to provide the contcinment bartier and with outer contoiners to serve as protection for the inner container. In any case, seal tightness should provide the pratection needed to prevent any spread of contamination during handling, transport, storage, and retrieval. 
Considerations requisite to an airtight seal would include eliminoting breathing of the pockoge which results in possible spread of contamination, moisture intake leading to corrosion, and possible escape of flammable gases.

iwany of the oforementioned probiems can be eliminated or controlled, depending upon the criteria established for the final TRU woste form.

Given t+ $\cdots$ general requirements, a woste container design should incorporate acceptable:

- Pcckoce identificotion methods

- Design criteria to reflect expected quantities of TRU isotopes and potential impoct of criticality, self-heoting, gas generation, etc.

- Miaterial of construction for the storage and finol disposal* environment úncluding external and internal environments)

- Leakage prevention requirements

- Shielding requirements (or capability to utilize overpack)

- Goskets and closure materials and design conditions

- Handling methods

Given an adequate design, thie fabrication, inspection, testing and quality control/quality assurance steps neceisary to implement the design must be established.

A survey of waste containers utilized by DOE contractors revealed the extensive number of containers/pockages utilized (see Table 1).

\footnotetext{
Retrievability should be considered, if required.
} 


\section{TABLE 1}

RESULTS OF WASTE CONTAINER SURVEY OF DOE WASTE GENERATORS

\section{Type A Pcckages}

I. Nietal Drums (DCT Regulation)

$$
\begin{aligned}
& \text { ipec. 5B (178.82) } \\
& \text { Spec. 5D (178.84) } \\
& \text { Spec. 6A (178.97) } \\
& \text { Spsc. 6B (178.98) } \\
& \text { Spec. 6C (178.99) }
\end{aligned}
$$

Spec. 6J $(178.100)$

Spec. $6 K(178.101)$

Spec. 6L (178.103)

Spec. 6il (178.104)

Spec. 17C (178.115)

Spec. $17 \mathrm{H}(178.118)$

5pec. 42B (178.107)

Spec. $42 \mathrm{C}(179.108)$

\section{Fiber Drums}

Spec. $21 \mathrm{C}(178.224)$

3. Wooden Boxes

$$
\text { ipec. } 14(178.165)
$$

Spec. I5A (178.168)

Spec. 15B (178.169)

Spec. 15C (178.170)

Spec. 15D (178.171)

Spec. 19A (178.190)

Spec. 19B (178.191)

4. Fiberboord Boxes

Any Spec. 12 Series

(178.205 to |78.212)

(9û $\mathrm{kg}$ test minimum)

Spec. 23F (178.214)

Spec, 23H (178.219)

\section{Number of Users}

$3(208-L)$

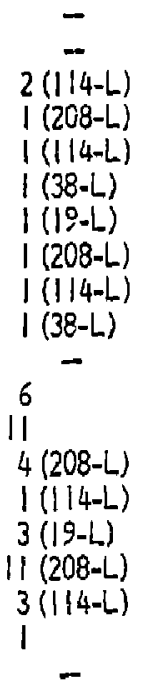

5

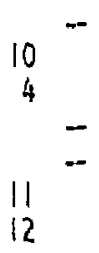

$1(12 A)$

$12(12 B)$ 


\section{TABLE I \\ (CONT.)}

\section{Type A Packages}

5. Cylinders

Any Spec. 3 Series

Any Spec. 4 Series

(178.47 to 178.58$)$

6. $\underline{\text { Spec. } 55(178.25)}$

7. 5 pec. $7 \mathrm{~A}(178.350)$
Number of Users

$$
2(3 A, 3 A A)
$$

?

NOTE: 17 packages were listed as being used by DOE contractors under the Spec. 7A classification.

1) Cylinders for $U F_{6}$

2) Strong Wozden Boxes

3) Steel Eoxes

4) Fiberboard Boxes

5) Steel Drums

6) Benelex Box (neutron sources)

7) Concrete Voults 
At present, more than 18 different packaging configurations are being used for interim storage of DOE low-level TRU wastes. Of these, only the DOT 17C steel drum and the $1.2 \mathrm{~m} \times 1.2 \mathrm{~m} \times 2.1 \mathrm{~m}$ DOT 7A plywood box are readily occeptable for direct shipment and isolation in the current design of WIPP. The proliferation of waste packages currently in use is a direct result of efforts of the various waste generators to pockoge their unique TRU wastes into containers able to meet the 20-year retrievability requirements under the differing conditions of on-site waste processing and storage. Completing the criterio, development of standardized TRU waste containers will be difficult without established parometers regording waste form and interim and find storage environment, In the selection of materials for construction of a porticular packaging system, it is important first to consider the charccteristics of the system, giving special ottention to extraneous factors that may influence decomposition. Since these factors would be peculiar to a particular system, it may be impracticul to offer hard and fost rules that would cover all situations. Tables 2 and 3 present a compilation and description of various TRU waste packages in use. Table 4 provides a list of DOE facilities and the principal container types used for TRU waste.

The commercial sector is expected to follow the gunerol leod of DOE on future woste containers. Due to the lack of data an previous TRU waste disposal practices from the commercial sector, it can only be postulated that DOT $7 \mathrm{~A}$ containers, primarily the $17 \mathrm{H}$ and $17 \mathrm{C}$ drums (both 208-liter and 1/4-liter) were utilized in conjunction with the DOT 7A plywood box $(1.2 \times 1.2 \times 2.1 \mathrm{~m})$.

The AGNS reprocessing plant has identified the use of three mild steel drums: 1/4-liter, 208-liter and 303-liter. Further, a 208-liter stainless steel drum wos identified as well as a cladding hulls container. It appears appropriate to assume that the AGNS TRU waste containers and the DOT 7A box should cover the contoiners expected to contain cammercially generated TRU waste in the future.

It is worth noting that the previous description of woste corirainers reflects recent practices. It is known that earlier practices (1950s and 1960s) utilized fiberboard and cardboard boxes for hondling until the waste was buried in shallow-land burial sites. Thus, much of the actual buried waste has breached its container and migroted into surrounding soil. 
TABLE 2

TRU LOW-LEVEL WASTE PACKAGES IN USE

\section{Package Description}

Volume

$\left(m^{3}\right) \quad\left(f t^{3}\right)$

208-L steel drum, DOT 17H, zinc dipped,

polyethylene (PE) bag liner

208-L steel drum, DOT I7H interior and

exter ior painted, PE bog li, ier

0.21

208-L stainless steel drum, COT 17H, PE bag liner

0.21

208-L steel drum, DOT 17C, interior and

exterior pointed, $P E$ bog lizer

0.21

208-L steel drum, DOT 17C interior and exterior pointed, $90 \mathrm{mil}$ high density polyethylene

(HDPE) liner; lead shielded (optional)

208-L steel drum, DOT $17 \mathrm{C}$ zinc dipped, $90 \mathrm{mil}$

HDPE liner

$0.21 \quad(7.42)$

114-L stainless steel drum, PE bag liner

0.11

1/4-L steel drum, interior and exterior pointed

$P E$ bog liner, 2 each inside concrete cask

Corrugated metai pipe, zinc dipped, $0.76 \mathrm{~m}$ diameter $\mathrm{x}$

$6 \mathrm{~m}$ long

208-L steel drum, zinc dipped, 90 mil HDPE liner, inside concrete culvert

Welded steel box, 3 mrn thick, PE bag liner, random sizes, will fit inside supertiger

Rondom

Fiberglass reinforced polyester (FRP) plywood box, $1.2 \mathrm{~m} \times 1.2 \mathrm{~m} \times 2.1 \mathrm{~m}, \mathrm{PE}$ bog liner

FRP plywood box, rondom sizes, PE bog liner

Steel bin, $1.2 \mathrm{~m} \times 1.5 \mathrm{~m} \times 1.8 \mathrm{~m}$, 12-gouge, ló6-L DOT $17 \mathrm{H}$ steel drums or I" thick plywood box placed inside

FRP plywood box, random, steel drums inside

Rendom

FRP plywood boxes, cold rolled steel boxes, inside concrete culvert

Random 
IAldL 3

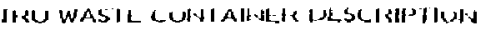

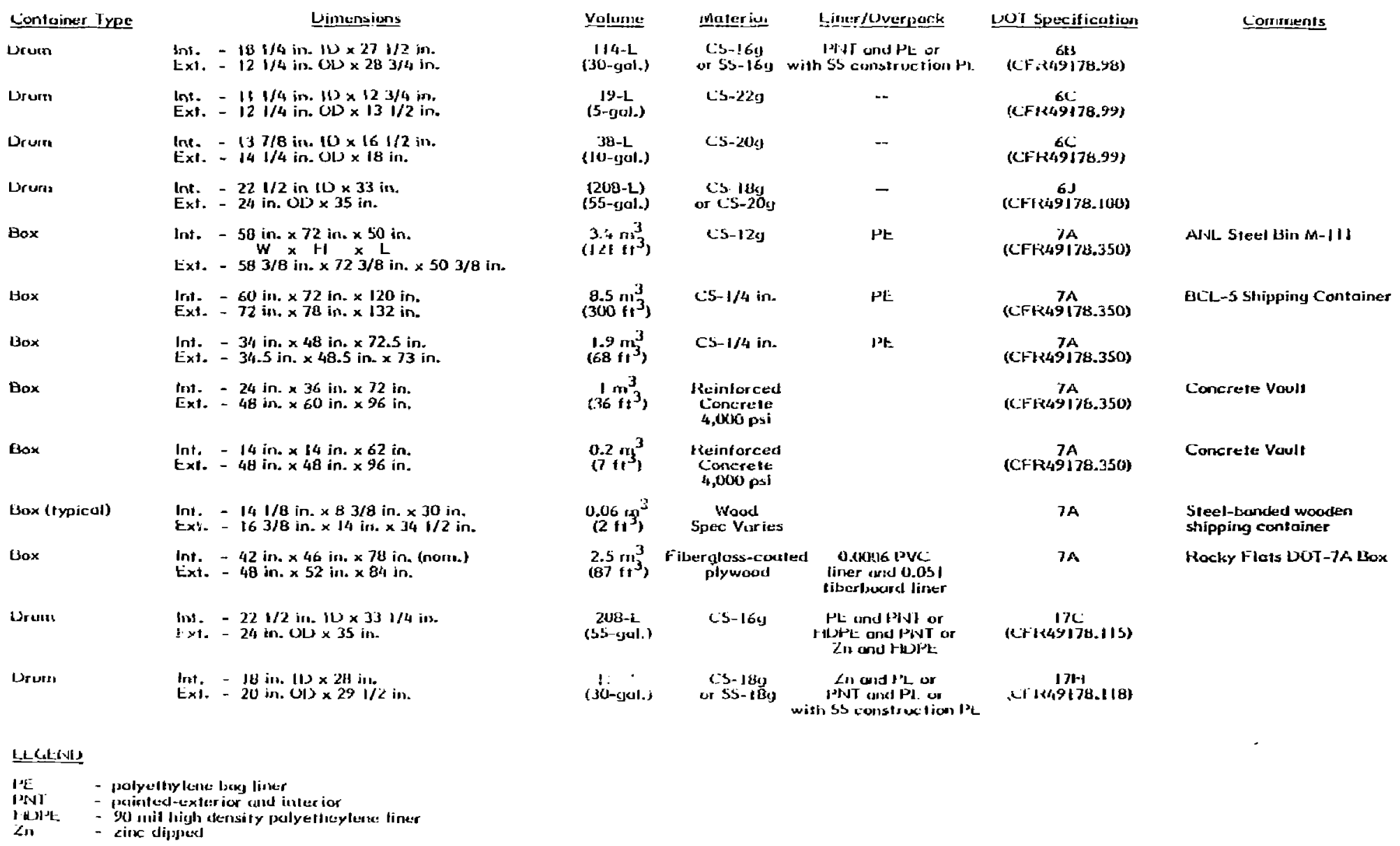


TABLE 4

TRU WASTE CONTAINER UTILIZED BY DOE WASTE GENERATORS

\begin{tabular}{|c|c|}
\hline Waste Generator & Contoiner \\
\hline Rocky Flots Plant & $\begin{array}{l}\text { 17C Drum } \\
\text { Plywood Box }\end{array}$ \\
\hline Hanford & $\begin{array}{l}\text { 17C Drum } \\
\text { Plywood Box }\end{array}$ \\
\hline Miound Facility & $\begin{array}{l}\text { 17C Drum } \\
\text { Plywood Box }\end{array}$ \\
\hline Los Alamos Scientific Loboratory & $\begin{array}{l}\text { 114-L Drum } \\
17 C \text { Drum } \\
\text { Corrugated Mietal Pipe } \\
\text { Plywood Box }\end{array}$ \\
\hline Sovannah River Plant & $\begin{array}{l}\text { 17C Drum } \\
\text { Plywood Box } \\
\text { Steel Box }\end{array}$ \\
\hline Oak Ridge National Laboratory & $\begin{array}{l}\text { 114-L Stainless Steel Drum } \\
\text { 17H (Stain'ess Steel) }\end{array}$ \\
\hline Argonne National Laboratory - East & $\begin{array}{l}\text { Steel Bin } \\
\text { 17H Drum } \\
\text { Plywood Box }\end{array}$ \\
\hline Lawrence Livermore Laborctory & $\begin{array}{l}\text { 17H Drum } \\
\text { Welded Steel Box }\end{array}$ \\
\hline Lawrence Berkeley Laboratory & 17H Drum \\
\hline Battelle Nemorial Institute & $17 \mathrm{HDrum}$ \\
\hline Atomics International & 17H Drum \\
\hline EGaG Idaho & 17C Drum \\
\hline
\end{tabular}


Appendix D presents the preliminary waste-occeptance criteria for the WIPP focility. These criterio include the July 1, 197\%, version (Section 2.0) and the updated version utilized in the Draft EIS for M/PP (Section 3.0). The criteria recognize two levels of TRU waste: contoct-hondled and remotely-handled (established by surface rediation dose of the waste coniainers); and they address combustibility, gas generation, immobilization, expiosives, pyrophorics, and hazardous materials as they inipart the waste form. The waste containers have G 10 year design life requirement to allow retrievability and are required to be LiOT Type A struciures. The waste package criteria establish design limits for waste pacisage, structure, handling, weight, dimensions, thermal power, criticclity and radiation surface-dose rate and contamination level. Tables 5 through 7 present the design waste containers anticipoted at WIPP.

A waste container is considered to be the drum, box, or conister which immediately surrounds the ifU waste, including any associated hardware (such as liners or spacers internal to the container). A proper container and pockaging design are the foundations of TRU waste material shipping and handling. The waste contuiner and/or prikage must meet the requirements of the Department of Transportation and the NRC for transport to the burial facilities. These requirements are met either throu-', containel design (woll thickness) or protective overpacks. Thu reguiations specify the mechanical properties of the woste packoge relative to applicable transport conditions, wherein the severity of these conditions is reluted to the quantity of the spesific rodionuclides contained. The regulations also specify thermal behovior of the waste packoge under normal transport, and hypothetical accident situations for packages containing an excess of type A quantities. Normal conditions exist at ambient temperatures of $-40^{\circ} \mathrm{C}$ to $54^{\circ} \mathrm{C}$, while accident conditions exist when the package is exposed to $802^{\circ} \mathrm{C}$ for 30 minutes. It is worth noting that both the SOT and NRC criteria dealing with radioactive waste transportation are under revision as discussed in Appendix $F$. These revisions may impuct final container design and/or waste form for TRU waste. 
TABLE 5

DEFEINSE CONTACT-HANDLED TRU WASTE (DRUWI)

Remarks

\begin{tabular}{|c|c|c|}
\hline $\begin{array}{l}\text { Type of } \\
\text { contoiner }\end{array}$ & $\begin{array}{l}\text { DOT-17C 55-gallon (208-lite:i } \\
\text { steel drum }\end{array}$ & $\begin{array}{l}\text { Rocky Flats Plant } \\
\text { Standard } 5 X-200\end{array}$ \\
\hline $\begin{array}{l}\text { Liner } \\
\text { (if used) }\end{array}$ & $\begin{array}{l}0.09 \text {-in }(2.3 \mathrm{~mm}) \text { thick, rigid- } \\
\text { polyethylene inner iners }\end{array}$ & $\begin{array}{l}\text { Rocky Flats Plant } \\
\text { Standard } 5 X-202\end{array}$ \\
\hline $\begin{array}{l}\text { Weight of } \\
\text { contoiner }\end{array}$ & $640 \mathrm{lb}(290 \mathrm{~kg})$ & \\
\hline $\begin{array}{l}\text { Surface- } \\
\text { dose rate }\end{array}$ & $\leq 200 \mathrm{mrem} / \mathrm{hr}$ & $\begin{array}{l}\text { Interim waste- } \\
\text { acceptance criterion }\end{array}$ \\
\hline $\begin{array}{l}\text { Surface } \\
\text { contamination }\end{array}$ & Limits in 49 CFR 173.397 & $\begin{array}{l}\text { Interim waste- } \\
\text { occeptance criterion }\end{array}$ \\
\hline \multirow[t]{2}{*}{$\begin{array}{l}\text { Waste } \\
\text { properties }\end{array}$} & $\begin{array}{l}\text { Combustible: paper, cardboard } \\
\text { boxes, wooden boxes, plastic bags, } \\
\text { rubber scrop, rags, surgical } \\
\text { glowes. . 'othing, etc. }\end{array}$ & \\
\hline & $\begin{array}{l}\text { Noncombustible: residues or } \\
\text { solutions from chemical process- } \\
\text { ing, building rubble, metal, } \\
\text { glosswore, sludges, and ocids }\end{array}$ & \\
\hline
\end{tabular}




\section{TAELE 6}

DEFENSE CONTACT-HANDLED TFU WASTE (BOX)

\begin{tabular}{|c|c|c|}
\hline & & Remorks \\
\hline $\begin{array}{l}\text { Type of } \\
\text { containe: }\end{array}$ & $\begin{array}{l}\text { DOT-7A } 4 \times 4 \times 7-\mathrm{ft}(1.2 \mathrm{~m} \times 1.2 \mathrm{~m} \\
\times 2.1 \mathrm{~m}) \text { plywood box }\end{array}$ & $\begin{array}{l}\text { Rocky Flats Plont } \\
\text { Standards } 5 X-2 ! 1 \text { (ply- } \\
\text { wood box) and } 5 X-207 \\
\text { (fiberglass-reinforced- } \\
\text { polyester coating) }\end{array}$ \\
\hline $\begin{array}{l}\text { Veight of } \\
\text { container }\end{array}$ & $\begin{array}{l}\text { Vioximum } 10,000 \mathrm{lb}(4,500 \mathrm{~kg}) ; \\
\text { typicol } 3,000 \mathrm{lb}(1,360 \mathrm{~kg})\end{array}$ & \\
\hline $\begin{array}{l}\text { Surface- } \\
\text { dose rate }\end{array}$ & $\leq 200 \mathrm{mrem} / \mathrm{hr}$ & $\begin{array}{l}\text { Interim waste- } \\
\text { occeptance criteriinn }\end{array}$ \\
\hline $\begin{array}{l}\text { Surface } \\
\text { contamination }\end{array}$ & Limits in 49 CFR 173.397 & $\begin{array}{l}\text { Interim waste- } \\
\text { acceptance criterion }\end{array}$ \\
\hline \multirow[t]{3}{*}{$\begin{array}{l}\text { Woste } \\
\text { properties }\end{array}$} & $\begin{array}{l}\text { Combustible: paper, cardboard } \\
\text { boxes, wooden boxes, plastic bags, } \\
\text { rubber scrap, rags, surgical gioves, } \\
\text { clothing, etc. }\end{array}$ & \\
\hline & $\begin{array}{l}\text { Noncombustible: residues or solu- } \\
\text { tions from chemical processing, } \\
\text { building rubble, metal, glosswore, } \\
\text { sludges, and acids }\end{array}$ & \\
\hline & $\begin{array}{l}\text { Equipment and mater ials too large } \\
\text { for } 55 \text {-gallon drums }\end{array}$ & \\
\hline
\end{tabular}




\section{TABLE 7}

DEFENSE REIVIOTELY HANDLED TRU WASTE

Remarks

Type of container Steel conister (I200-liter internal volume)

Proposed for WIPP

Weight of

contain:s

$10,000 \mathrm{lb}(4,500 \mathrm{~kg})$

Surface-

$\leq 100 \mathrm{rem} / \mathrm{hr}$

reference repository

dose rote

Limits in 49 CFR 173.397

contamination

Woste

properties

Primarily noncombustible: concrete, steel, process sludges, etc.

Proposed wasteacceptance criterion

Proposed wasteacceptance criterion 


\subsection{NTRODUCTION}

The disposal of any type of hazardous material, whether nuclear ar nonnuclear, should involve the permonent removal of the material from man's biosphere. This can be accomplished either by converting the hazordous material to $n e$ hazardous material or by disposing of the material in such a way that it carnot affect man's environment. The present state-of-the-art technology is based upon a "defense-in-depth" philosophy wherein the waste, waste form (including pretreotment and immobilization), and the woste centainer make up a waste package which is isolated from man and his biosphere by the surrounding geologic media and other, engineered barriers. Currently, solidified transurenium (TRU) contaminated wostes are contained and stored/buried in a myriad of containers ranging from 1/4-liter carbon steel drums and larger drums constructed of different materials, to metal bins and large plywood boxes.

In the past, no credit has been given to the containers once they have been buried, ${ }^{3}$ even though some proponents of advanced container designs advarate engineered containers as a means of ensuring the satisfactory performance of shollow land buriol grounds. 55 The purpose of a container is to provide ease of handling, minimize personnel exposure ond prevent loss of radiocctivity from the waste package prior to storage/burial. ${ }^{4}$

In the present TRU waste management program, the waste container will be evaluated as part of the overall "waste package." Thus, it is important to identify the different waste pockaging systems utilized and proposed for TRU waste, and to document their cherocteristics in a doto base for use in future studies.

\subsection{TRANSURANIC (TRU) CONTAMINATED WASTES ${ }^{2}$}

The transuranic contaminated wastes include isotopes of americiurn (Am), berkelium (Bk), californium (Cf), curium ( $\mathrm{Cm}$ ), einsteinium ( $(\mathrm{ss})$, neptunium (Np) and plutonium ( $\mathrm{Fu}$ ). Some TRU waste generators also include one or more uranium $(U)$ isotopes in the classification of a waste TRU-contaminated. 
Transurcnic wastes are especially significant becouse they have long half-lives and because some ore rother radiotoxic. Transuranic radionuclides exhibit both of these properties and are primarily produced by the U-238 copture of single or of multiple neutrons curing the operation of a nuclear reactor. Spent fuel elements are reprocessed in on oftempt to remove plutonium, but because the seporation is not complete, the resulting high-cctivity liquids still contain some plutonium as well as other transuronics. Similarly, transuranic contamination of low-octivity wastes occurs when the transuranic materials ore handled or processed, which is primorily of federol facilities involved in research and development and nuclear weapons production.

Transuranics ore persistent in the environment and, as a general rule, are strongly retained by soils. They are not eosily transported through most food chains, altinough some reconcentration does tcke place in the aquatic food chain. They pose only a slight biological hozord to humons upon ingestion becouse the $i$ are only weakly absorbed through the gastrointestinal tract. A greater hazard results from inhalation since they behave like normal dust and fractionate cccordingly. Adverse heolth effects in the lung or elsewhere, depend on the particle size and the solubility of the inhaled contaminated dust. Upon entering the bloodstream (either by ingestion or inhalation), TRUs readily accumulate in bone and liver tissue, and can significantly increose the risk of cancer. Appendix $B$ presents o more complete overview of TRU radivisotopes.

In 1970, the Atomic Energy Commission (AEC) directed that all AEC (now Department of Energy, DOE) facility-generated wastes contaminated with 10 nanccuries per gram $(\mathrm{nCi} / \mathrm{g})$ of TRU radionuclides be segregated from other rodioactive waste. As a result, it is required that these trarisuranic wastes be stored in a readily retrievable manner ensuring that the waste packoges remain infact and contaminatian-free for an interim storage period if at least 20 years. ${ }^{6}$ When o federal repository becomes operational, this waste must be retrieved and transported to the facility for deep geologic disposal. ' (A similar requirement was proposed for commercially-genercted TRU Woste in the September 12, 1974 Federal Register.) 


\subsection{TRU WASTE NIANAGEMEINT RROGRAW!}

The development of the NRC's TRU Waste ivianggement Frogram by Lawrence Livermore Loboratory requires shat extensive information and ato bose be established for developing waste classification, form and container requirements os they pertain to transuranic contominotec (non high-level) waste which requires cisposal in o deep geologic repository.

Figure 1-1 presents a proposed scheme for the TRU woste form criterio development progrom. As con be seen from this figure, TRU wostes are generated from military and Department of Energy (DOE) activities, the commercial sector and ather miscellaneous sources. In developing the TRU coto bose and initioting the subsequent work, it is first necessory to identify the sources of TRU waste, develop the inventory, and identify the various forms of this wasie. This information will characterize the waste. From the characterization and the development of a waste classificotion scheme for TRU waste, it then becomes possible to iejentify the TRU wostes which require deep geologic disposol.

After the initial work, general criteria selection studies would be initiated and the data base would be revised to develop the base case scenarios to be used for all initial studies and program evaluation.

Utilizing the various categories defined in the waste elassification stuay, (recently revised from three $(3)^{25}$ to five $\left.(5)^{56}\right)$, it is necessory to examine and evaluate the treatment technologies avoilable for processing the as-generated TRU wastes. Such evaluations should primarily review the generated waste form of the contaminated material to determine whether or not the means of reducing the volume or the combustibility possibilities, or other similar technical considerotions, are appropriate. Simultaneously, various means shouid be examined for immobilizing the residue that results from such treatment technologies or the unprocessed waste material. It is noted that not only new generated wastes but old buried wostes should be considered. As new technologies and residueimmobilization methods are identified, the waste container can be defined. 


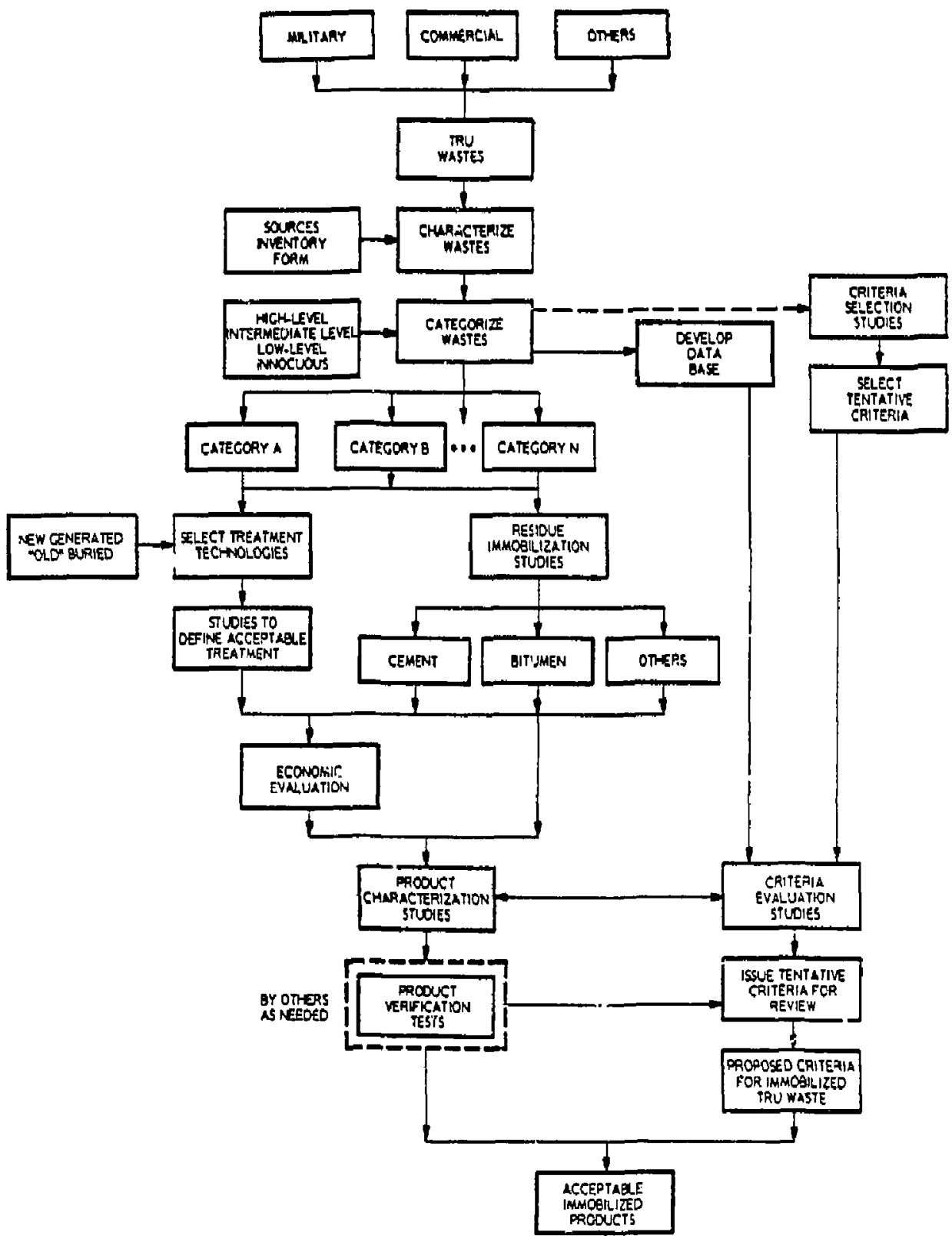

FIGURE I-I

TRU WASTE FORM CRITERIA

DEVELOPMENT PROGRAM 
Bosed upon extensive modeling and other evaluations, tentative criterio could then be developed for the waste form in the final immiobilized matrix. Such criterio might be either qualitative or quontitative in nature and would reflect the currently available technology as well as the means for determining the applicability of new technologies as they are developed.

With the identification of these technologies and the evaluation of the opplicability of such technologies, an economic analysis could be performed to determine the cost impact of the criterid. While Figure $1-1$ indicates the general outline and approach of the program, the problem of defining the TRL waste form and potential package options is more complicated in that the number of parameters being evaluoted is quite large. Figure 1.2 presents a schematic diogram of the varicus major parameters of this progrom, as well as the interactions which must be considered in the development of eriteria conceming proposed technical solutions to TRU' waste handling and o method for evaluating the impact of this criterio. 


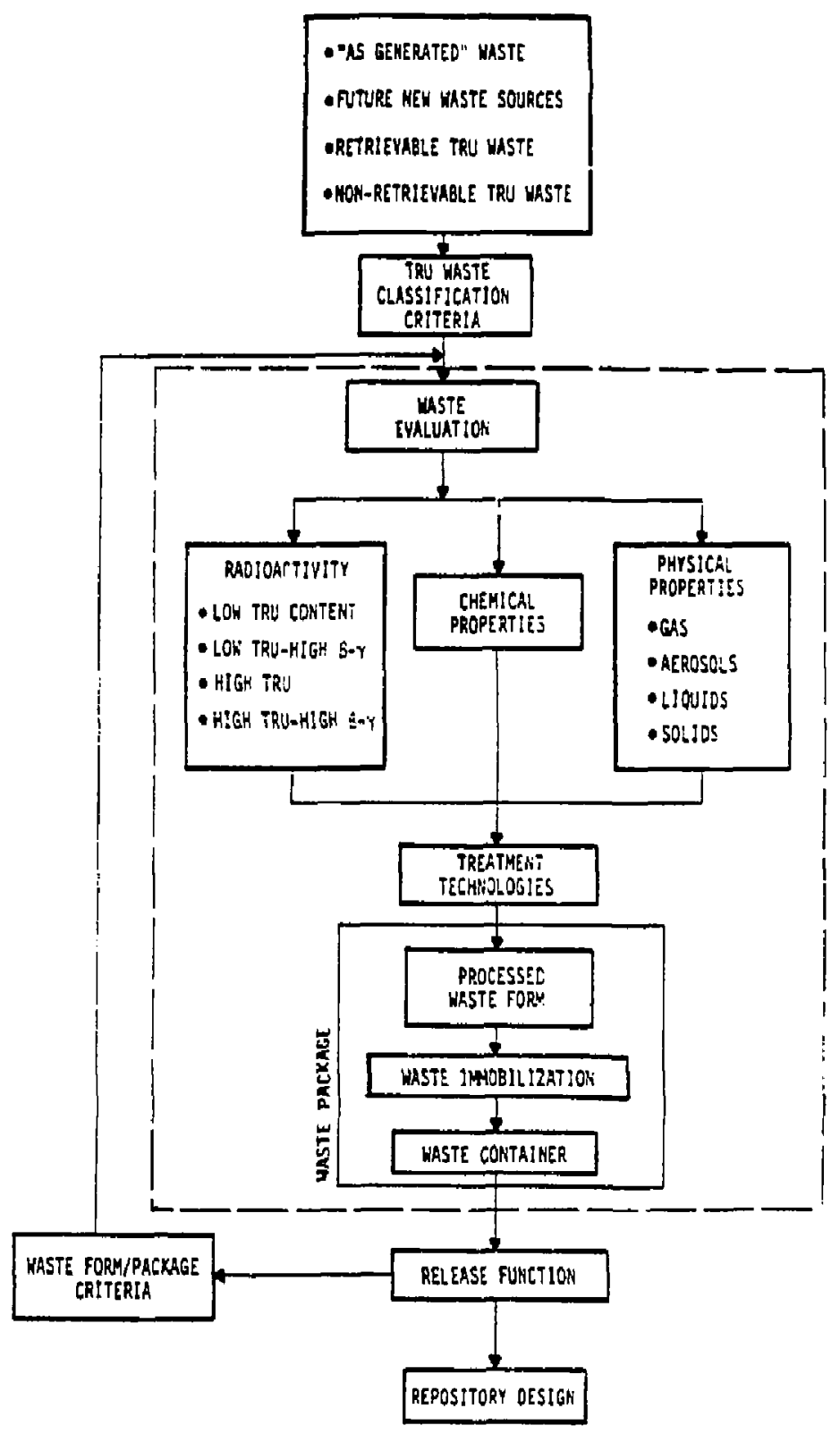

FIGURE $1-2$

TRU WASTE FORM, CONTAINIER AND PACKAGE

CRITERIA EVALUATION METHODOLOGY 


\subsection{BACKGROUND}

The purpose of this section is to provide a brief overview of the TRU contaminated waste problem and to establish the necessary background iata for the development of the TRU waste container characterization dato base. This section will briefly review TRU contarninated waste sources, inventory, and form.

In the early days of the nuclear age, little thought was given to the disposal of radioactive contaminated material since it was secondary to the main task at hand. Incleed, the present proctice of shallow land burial seems to have evolved from the practice of using sanitary landfill buriol techniques to dispese of various wastes near where they were generated. Later, os it became opparent that the national laboratories would became permanent federally supported facilities, increosed attern: in was paid to waste disposal problems, especially those related to land buriki. As research, development and production programs were expanded and macified, the waste moterials and used equipment to be buried became much more varied and more difficult to manage. Solia radiocctive waste had usually been buried in the most accessible and convenient vacant place, without a great deal of thought concerning long-term consequences. Fortunately, the amount of rodioactive material was not large at that time. Inceed, the tronsuranium (TRU) elements were very strictly conserved and, at first, solid waste-containing separated fission products did not present a serious land burial problem. Wartime pressures for production, combined with lack of knowledge or understanding, led to siting and operational practices that, in many situotions, are unsatisfactory by present-day standards. ${ }^{5}$

\subsection{SOURCE OF TRU CONTAMINATED WASTE}

Nearly all operations that produce or use nuclear materials generate radioactive waste. Most of this waste comes from the Department of Energy's reactors and facilities, commercial nuclear power plants, and federal (military) and commercial nuclear fuel cycle activities-mainly fuel fabrication and reprocessing facilities. Though commercial reprocessing facilities are currently aperating, the DOE hos four reprocessing facilities either in operation or on standby. 
High-level liquid waste contains many fission products and small amounts of transuranics (such as plutonium) which are not recovered during the reprocessing operation. Besides being found in high-level waste, transuranic (TRU) materials in various concentrations ore also found in other waste such os is generated by plutonium fuel fabrication and fuel reprocessing focilities, and by laboratories which use transuranic elements. This waste generally consists of expendable iterns such os absortent paper, clothing, gloves, plastic bags and equipment; ion exchange resins or filters from effluent treatment systems; and fuel clodding hulls which remain ofter reprocessing. ${ }^{5}$

To adequately define the sources of TRU waste in the U.S., it is necessary to identify oll current inventories of such wastes, as well as the focilities which generate or may generate such wastes in the future. In many cases, it is difficult to clearly define the TRU wastes generated without identifying the overall radioactive woste gen:eration rates and characteristics of the waste handled at each facility.

At present, only eight DOE facilities are burying or storing TRU contaminated waste. A list of these sites and the quantity of waste buried or stored is provided $\mathrm{i}: 1$ Table 2-1. The list of DOE facilities generoting TRU waste is substontialiy larger and is presented in Toble 2-2. This waste can and does include almest anything used in the reprocessing of spent fuel from the fabrication of nuclear weapons, and a myriad of research and deve opment (R\&D) activities. Toble 2-3 presents a typical partial list of TRU-contaminated waste generated by DOE facilities.

TRU waste has been disposed of at five of the six commercial burial sites. ${ }^{*}$ This waste was generated by the commercial LWR industry, as well as by the Department of Energy (DOE) and its predecessor ERDA, and AEC. These sites

\footnotetext{
*Beotty, NV; West Valley, NY; Maxey Flats, KY; Richlond, WA; Sheffield, IL; Barnwell, SC (no transuraric waste except small quantities of Am-2:4! of Barnwell). TRU is defined as concentrations greater than or equal. . $10 \mathrm{nCi} / \mathrm{g}$.
} 
TABLE 2-1

CUMULATIVE VOLUME OF DOE-GENERATED TRU-CONTAMINATED SOLID WASTE* BURIED AND/OR STORED AT DOE SITE $5^{5}$

\begin{tabular}{|c|c|c|}
\hline \multirow[b]{2}{*}{ Site for Burial/Storoge } & \multicolumn{2}{|c|}{$\begin{array}{l}\text { Cumulative Volume } \\
\text { TRU-Cubic Meters } \\
\text { (kg TRU isotopes) }\end{array}$} \\
\hline & Retrievable & Non-Retrievable \\
\hline Honford Reservation & $\begin{array}{c}7,300 \pm 10 \% \\
(83.2)\end{array}$ & $\begin{array}{c}155,000+200 \% \\
(365)\end{array}$ \\
\hline Idaho National Engineering Laboratory & $\begin{array}{c}36,000 \pm 10 \% \\
(296.9)\end{array}$ & $\begin{array}{c}60,000 \pm 30 \% \\
(361)\end{array}$ \\
\hline Los Alamos Scientific Laboratory & $\begin{array}{c}2,000 \pm 5 \% \\
(35.3)\end{array}$ & $\begin{array}{c}16,000 \pm 50 \% \\
(15)\end{array}$ \\
\hline Nevada Test Site & $173 \pm 10 \%$ & $\begin{array}{l}(0) \\
(0)\end{array}$ \\
\hline Oak Ridge National Laboratory & $\begin{array}{c}1,000 \pm 5 \% \\
(18.1)\end{array}$ & $\begin{array}{c}6,000 \pm 6 \% \\
(13)\end{array}$ \\
\hline Pantex & $\begin{array}{c}1.1 \pm 10 \% \\
(2.4 ?)\end{array}$ & $\begin{array}{c}32 \pm 10 \% \\
(\sim 0)\end{array}$ \\
\hline Sandia Loboratory - Albuquerque & $\begin{array}{l}(0) \\
(0)\end{array}$ & $\begin{array}{c}2 \pm 10 \% \\
(\sim 0)\end{array}$ \\
\hline Sovonnah River Plant & $\begin{array}{c}1,700 \pm 5 \% \\
(58.6)\end{array}$ & $\begin{array}{c}31,000 \pm 5 \% \\
\text { (7) }\end{array}$ \\
\hline TOTAL & 268,0 & $\begin{array}{l}+125 \% \\
-40 \% \\
59)\end{array}$ \\
\hline Stored & $\begin{array}{r}48,000 \\
(L\end{array}$ & $\begin{array}{l}(5-10 \%) \\
4.3)\end{array}$ \\
\hline Contaminated Soil & $1,2 \mid B$ & $\begin{array}{l}0+200 \% \\
0)\end{array}$ \\
\hline
\end{tabular}

\footnotetext{
These values are waste generation rates by various DOE facilities and do not reflect inventory accumulations/reductions of TRU at the waste generator facilities. Volumes ore giver, to two significant figures or nearest thousand cubic meters.
} 
TABLE 2-2

DOE FACILITIES GENERATING TRU CONTAMINATED WASTE ${ }^{5}$

Los Alamos Scientific Loboratory

Lovelace Inhalotion Toxicology Research Instifute inound Focility

Pantex Plant

Ames Laboratory

Rocky Flats Plant

Atomics International (Santa Susana, CA)

Sandia Laboratory (Albuquerque)

Lawrence Livermore Labcrotory

Lawrence Berkeley Laborotory

Argonne National Loboratory (Eost, West)

Brookhaven National Laborotory

Battelle Miemoriol Institute

EG\&G Idaho, Inc.

Nevada Test Site (Mercury Naeg Soils Loboratory)

Oak Ridge National Laboratory

Poducah Gaseous Diffusion Plant

Bettis Atomic Power Laboratory

Noval Reactors Facility

Battelle Pacific Northwest Labaratory

Rockwell Hanford Company

United Nuclear Industries

Westinghouse Hanford Company

Savannah River Plent 
TABLE 2-3

TYPICAL DOE TRU-CONTAMINATED WASTE 29

$\begin{array}{ll}\text { First Stage Sludge (Reprocessing) } & \text { Grit } \\ \text { Second Stage Sludge (Reprocessing) } & \text { Blacktop Concrete Dirt \& Sand } \\ \text { Organic Set ('ps (Oil Solids) } & \text { Cement Insulation \& Filter Media } \\ \text { Special Set Ups (Cement) } & \text { Sand, Slag and Crucibles } \\ \text { Evaporated Salts } & \text { Electrorefining Solt } \\ \begin{array}{l}\text { Combustibles (Paper, Rags, } \\ \text { Gloves, Pol,; }\end{array} & \text { Resin } \\ \begin{array}{l}\text { Non-Compressible, Non- } \\ \text { Combustibles }\end{array} & \text { Raschig Rings } \\ \text { Dirt } & \text { Metal Scrap } \\ \text { Sludge } & \text { Equipment Boxes } \\ \text { Hot Cell Waste } & \text { High-Level Acid } \\ \text { Americium Process Residue } & \text { Hi Level Caustic } \\ \text { Graphite Wiastes } & \text { High-Level Sludge/Cement } \\ \text { Baneiex ond Plexiglas } & \text { Contaminated Soil } \\ \text { HEPA Filters } & \text { Wood } \\ \text { Plastics, Teflan, PVC } & \text { Laundry Sludge } \\ \text { Leaded Rubber Gloves \& Aprons } & \text { Miscellaneous Equipment } \\ \text { Brick, Fire } & \end{array}$


have accepted wastes generated in the fuel cycle, primorily in fuel fabrication and spent fuel reprocessing, as well as numerous miscellaneous R\&D activities and small commercial uses of TRU radioisotopes. The present inventory of TRUcontominared waste is limited primorily to DOE-cenerated waste (though shipments hove now been terminated) and R\&D fuel fabrication activities involving plutonium. The NRC does not have records on the volume of commercial transuranic contamirated waste buried at commercial shallow land burial sites, but estimates that about 123.4 kilograms of plutonium were buried at five of the six sites through $1977^{5}$ (see Table 2-4). The best available information indicates that the cumulative DOE-generated TRU waste (through 1970) shipped to these commercial burial grounds contained obout $7.6 \mathrm{~kg}$ of TRU isotopes.

The present (as of October 1, 1978) TRU inventory of contaminated wastes, soils and sediment is as fallows: ${ }^{5}$

$\begin{array}{llr}\text { Retrievably stored - DOE } & 494 \mathrm{~kg} \text { TRU } & \sim 48,000 \mathrm{~m}^{3} \\ \text { Previously buried - DOE } & 759 \mathrm{~kg} \text { TRU } & \sim 268,000 \mathrm{~m}^{3} \\ \begin{array}{l}\text { Contaminated soils and sediments - } \\ \text { DOE }\end{array} & 190 \mathrm{~kg} \text { TRU } & \sim 1,218,000 \mathrm{~m}^{3} \\ \text { Previously buried - Commercial } & 123 \mathrm{~kg} \text { TRU } & \text { unknown }\end{array}$

In oddition to an inventory of presently buried/stored TRU-contaminated waste, it is important to project future woste generation rates and radioactivity levels so that policy-makers can determine the impoct of any proposed rulemaking change. As indicated above, a total of 316,000 cubic meters of FRU solid waste was in storage at DOE sites os of October 1978. By October 1984, it is anticipoted that the retrievable inventory will increase by a factor of nearly two, while the total waste in burial sites will remain unchanged. Consequently, the change in total inventory up to 1984 represents an increase of about I5 percent. It is not expected that the commercial TRU waste inventory will increase significantly unless reprocessing of spent fuel becomes national policy. A DOE analysis assumed only $280 \mathrm{~m}^{3} / \mathrm{yr}$ of commercial woste in the future. 5 This analysis presumed that no commercial fuel reprocessing would be undertaken. 


\section{TABLE 2-4}

CUMULATIVE WASTE INVENTORY AT COMNMERCIAL BURIAL SITES 5

\begin{tabular}{|c|c|c|c|c|}
\hline Site & $\begin{array}{c}\text { Total } \\
\text { Voiume Buried } \\
\left(10^{3} \mathrm{~m}^{3}\right) \\
\end{array}$ & $\begin{array}{l}\text { SNivi } \\
(\mathrm{kg})\end{array}$ & $\begin{array}{l}19.74 \\
\text { TRU } \\
(1 \mathrm{~kg})\end{array}$ & $\begin{array}{l}\text { TRU } \\
(\mathrm{kg})\end{array}$ \\
\hline Beoity & 58.054 & 698.247 & 14.3 & 14.3 \\
\hline Wiest Volley & 66.726 & 56.003 & 3.6 & 3.6 \\
\hline Worehead & 135.016 & 31.260 & 69.1 & 69.1 \\
\hline Richiand & 16.238 & 83.235 & 12.7 & 23 \\
\hline Sheffieid & 86.634 & 53.962 & 13.4 & 13.4 \\
\hline Bornwell & 142.873 & $456.863 *$ & - & - \\
\hline
\end{tabular}

* Cumulative through 1976 
TRU woste sources for both commercially- and DOE-generated woste are adoressed in detoil in Reference 5.

\subsection{TRU CONTAMirINATED WASTE CLASSIFICATION}

Within the regulations governing the manogement and disposal of radionctive waste, the NRC is developing o rodioactive waste classification system. The classificotion system is not intended to replace existing proctices, criterio, or regulations relating to the generation, packaging, handling, or transport of radioactive material; but rather, it will provide guidelines regording the ultimate disposition of waste containing specific concentrations of individual radionuclides including transuranic rodionuclides. As stated previously, the current regulatory position (as well as definition of TRU waste sources and inventory) is bosed upon a requirement for retrievable storage of all waste with a TRU content of 10 nanocuries per gram or above.

Ouring the regulatory process, issue was taken with some proctical considerations regarding implementation of the 1974 AEC rule--porticularly the 10 nanocurie per gram guideline. The general opinion wos that the 10 nanocuries per grom limit was not justified, and further, that the proposed rule shou:d be supported by an economic impact analysis demonstrating a positive cost-benefit ratio. Further, it was noted that no practicable, nondestructive assay method existed for the guideline. Other foctors identified included the difficulty, expense, and personnel exposures in performing assays. Additionally, it was feit that the forms, volumes and categories of wastes subject to federal manogement under the proposed rule posed significant logistical problems. viodifications or alternatives to the 10 nanocurie per gran' guideline were also suggested.

Upon review of the proposed rule and the comments received, the NRC staff determinec that the proposed rule was unworkable and initiated develiopment of regulations to govern the disposal of all radiacctive woste--not just TRUcontaminated waste. The stoff further initiated a study upon which to base o woste disposal classification system and provide a foundation for the fortheoming regulations and occompanying environmentol impoct statements. 25,56 
In an earlier report, the clossification system was examined for application strictly to TRU waste. ${ }^{7}$ The TRU functionai definition is intended to provide on interpretation of the basic NPPC waste manasement criterio in accordance with TRU woste requirements. The objectives of this system are:

- To clossify wastes according to requirements for their safe disposal

- To address the concerns of the public

- To implement the system without undue burcen on mose directly affected by it

A methodology, Rodioactive Waste Disposal Clossification System (RWDCS), ${ }^{56}$ was developed to provide an acceptable means of determining levels of ThU concentration requiring deep geologic disposal, engineered containment, e.g., shallow-land burial, and disposol os nonradioactive waste. ${ }^{50}$ In this clossification system wostes are categorized according to characteristics relating to their dispasal ano classes are defined by a consistent application of sofety criteria.

Becouse the potential hozard to the public is directly related to the radioactive moterials in the waste, quantified definitions for the classes are given in terms of the maximum average concentration (MAC) of rodioactive materials allowed in the class. For a specified level of safety, woste disposal concentration guides (DCG) can be specified and wastes can be classified to ensure the safe disposal of the woste. Similorly, a disposal facility can be designated to occept various classes of waste according to the existence of potentiol pathwoys to man and other conditions specified in the RWDCS. If the radionuclide concentrotions in the waste are less than the DCGs for Closs $C$ woste, the waste can be safely disposed of in a focility licensed to handle Class $C$ waste. Similarly, waste with higher concentrations might be classified as Class $\mathrm{B}$ woste and must be disposed of in a more restrictive facility licensed for Class $B$ waste. In this morner, the public is protected against potential hazards from the Class $B$ waste of least to the same extent as they are protecied fram the Class $C$ waste. Quantifying the desired degree of safety for the public and specifying DCGs for each class allows for a consistent treatment of all radioactive woste. 
The waste disposal classification system which hos been developed is given in Toule 2-5. The disposol clossificotion system is not directly concerned with disposol methods as such. Rather, it is the existence of potentiol pathways and the existence of o period of restricted land use which is postuloted. Class $E$ waste is derived from onalyses using no odministrative control and reody occess to the waste by c reclaimer (e.g., municipal sanitary landfill). The DCGs for this class are the lowest of the set.

The Class $\mathrm{C}$ waste cotegory is siritilar to the Class $E$ cotegory except a per iod of administrative control must be in effect at the disposal site and concitions of cisposal are defined better (e.g.; shallow land burial). Therefore, DCGs for Class $D$ ore higher than for Class $E$.

Closs $C$ waste is appropriate for waste disposed of in such a monner that ready access by on unsuspecting reclaimer is unlikely le.g., intermediate depth lano burial). However, no administrotive control is applied. The disposol is postulated to be such that the well water event limits the concentrations.

Some waste can be disposed of at facilities providing addisional cover over the woste (intermediate depth burial), but for which there is no present potential for contaminating a well (no potoble oquifer). This waste is Closs $B$. There is still some limitation that should be ploced upon Class B waste. Although based upon the well woter event, this limitation also serves to limit the consequence of other unanticipated intrusion events that could occur witiout administrative control. Therefore, we have postulated that for focilities handling this waste, the hydrolocy cauld change after 150 years making the well woter scenario operable. The DCGs for this class ore just the DCGs for Class $C$ modified by opplying the 150-yeor decoy foctor.

Class $A$ has no upper coricentration limit. It is the defoult closs. The concentration limits provided for Class $A$ are the cctivity density of the pure isotope. Wastes with radioisotopic concentrations exceeding Class $B$ are outomatically categorized as Class A. Class A wastes should be oisposed of in facilities providing a high degree of isolotion. 
TALBLE 2-5

CATFGURIES OF NIRC WASTE DISPOSAL CLASSIFICATION SYSTLM ${ }^{36}$

CLASSE

CLASS D

CLASS C

CLASS BS

CLASS A
NO ADMINIS TRATIVE CONTROL

WOK\}KKER/RECLAIMER ACCESS

ADMIIVISTRATIVE CONTIKOL_ FOLLOWED BY RECLAIMER ACCESS

INO ADMINISTRATIVE CONTROL AFTEFS DISPOSAL OPERATIUNS WO RECLAINER ACCESS EXCEPT WELL WATER

ALMINISTRATIVE CONTIROL

INO RECLAIMER ACCESS EXCEPT WELL WATER AF TLIR ISO YEARS

"ISULATIGN"

(HEPOSITOKY) 
Based upon the current evaluation, the limits suggested in Table 2-6 cppeor oppropriote os guides for future work. These limits, when compored with the TRU isotope detection capobility, appear within the working ronge for various methoos or combinations of detection methoos. ${ }^{7}$

\subsection{TRU WASTE FORMS}

The management of TRU waste is complicated not only becouse of its physical cid chemical characteristics, but also becouse of the level of radioactivity and, due to its long half-life, the necessity for long-term containment.

TRU-contaminated wostes pose a significant problem to the regulatory ogencies becouse the variety of waste requiring disposal in geologic repositories is immense; there ore not only various :adioisotopes and radiation fields, but also o nearly infinite combination of physical forms and conditions and chemical constituents.

The four temporal groupings of TRU-contaminated wastes inciude the currently generated waste, future waste sources, readily retrievable TRU waste (currently at locitions such os INEL, Sovannah River, etc.) and non-retrievable TRU wostes. The volume of eoch of these sources cepends upon the mearis of disposal required at eoch level of contarnination. Thus, for the deep geolocic disposal of TRU-contaminated material, it is necessary to indicate some minimal cutoff point (as suggested by Class $A$ in Tobles 2-5 and 2-ó) above which all material would require disposal at a federal repository.

The first point of clorificotion is whether this definition will be applied to the "os generated" waste or to the "treated" final woste form. The problern with these two distinct locations in the process stream is the impact of future treatment technology. The use of volume reduction technology would not only reduce the volume of material to be disposed of in a geologic repository but also increase the concentration of the TRU isotopes of this waste package. It is possibly to the advantage of the waste generator to ensure that the generated waste is not processed to the extent that the waste content woult reguire 


\section{TABLE 2-6́}

PROPOSED NRC DISPOSAL CONCENTRATION LIMITS OF TRU RADIOISOTOPES FOR WASTE CLASSES $\left(: \mathrm{Ci} / \mathrm{cm}^{3}\right)^{56}$

\begin{tabular}{lccccc} 
& \multicolumn{5}{c}{ W ASTE CLASS } \\
Isotope & $E$ & & $D$ & $C$ & $B$ \\
Np-237 & $5.4-4$ & 0.02 & 0.3 & 0.3 \\
Du-238 & $3.4-4$ & 0.4 & $*$ & $*$ \\
Pu-239 & $3.0-4$ & 0.1 & 90 & 90 \\
Pu-240 & $3.0-4$ & 0.1 & 810 & 810 \\
Pu-241 & 0.015 & $5.9+3$ & $*$ & $*$ \\
Pun-242 & $3.1-4$ & 0.1 & 13 & 13 \\
Am-241 & $9.2-4$ & 0.4 & $*$ & $*$ \\
Am-243 & $9.2-4$ & 0.3 & 600 & $*$ \\
$C m-242$ & 0.024 & $*$ & $*$ & $*$ \\
$C m-244$ & $1.5-3$ & 130 & $*$ & $*$
\end{tabular}

Specific activity of the isotope 
geologic disposal. Unless the regulatory criterio are such that either the sconomic incentives are positive, thus making it to the advantage of the waste generator to reduce the waste regordless of TRU concentration, or the use of stote-of-the-art technologies is required, there is no incentive to further process the waste. Additional waste processing will potentially reduce not only the overall risk to the general public but also the occupotional risks to personnal involved in all aspects of the processing and handling of this waste.

Given that some regulatory development wil! ensure use of state-of-the-art technology, the four waste streams are then subject to further subciassification. Basically, there are three areas of classification: radicactive, chemical and physical.

Though defining TRU waste classification criterio will indicate which wastes require deep geologic disposal, several other subclassifications must be considered. The redioactivity characteristics of the waste material could be broken down into the following:

- Low-level TRU waste with no significant rodiation field

- Low-level TRJ waste with high beta-gammo radiotion field

- High TRU content waste with no significant radiation field

- High TRU content waste with high beto-gamma radiation field

These four subclosses should adequately cover oll wastes currently being considered in the TRU program. The uses of the terms "Jow" and "high" are all relative and refer basically to the extremes of the TRU contamination handled in the repository. The "low" TRU waste is that minimum quantity of TRU contamination defined by the regulations as requiring geologic disposal; the "high" content is the largest TRU level of contamination, exclusive of high-level waste, which can be generated from various sources in either commercial or government focilities. The potential of high beta-garnma radiotion fields must 
be considered in all aspects of the design. The problem with such jadiation fields is basically short-term (less ttun 1,000 yearsi, 'ut the impacts upon the waste generator, transporter and repository operator are quite significant in terms of occupational exposure, the requirements for stielding, possible heat dissipation, and off-gassing. Further, if retrievability is of concern, the cansequent occupationol hazards must also be considered. The high TRU content is only of potential concern when either a criticality problem develops or substantial offgases ore generoted, causing consequent problems.

The chemical properties of concern ore numerous. Not only is there the concern fcr potential rodiolysis auve to radiation fields, but olso for the large number of chemical forms in which TRU wastes might be generated. The problems with combustibility are self-evident, but other concerns, s'ich as pyrogenic behovior of chemicals, impact upon variuss waste forms, leachability and migration rates of nuclides, must also be considered. Thus, the final form of the waste as well as the final chemical species of the contominating TRU isotope are of importance.

The physical ond distribution characteristics of the waste include gases, liquids, cerosols, siurries and solids. Ecch of these requires unique handling and treatment, though the major concern in the physical areo is that of the final wasie form, and potential problems due to interaction of the waste form with the geologic media.

It is necessary not clly to identify waste sources, but also to analyze the composition of wiste from various points of generation in order to determine changes at the suircs and in subsequent handing methods that would reduce the waste generotion rote. Treatment, identification and development of processes and equipment for treatment to alter the waste form and provide suitable containment, as well as address operational and sofety ospects of waste management operation, would also stem from such an analysis.

Generically, three major categories of solid TRU-contarinated woste exist: combustible wostes, liquid and sludge wastes, and non-combustible wostes. The treatment of wostes, once generated, involves designing a system for sorting and 
classifying appropriate to volume reduction, and passivation treatment to mirimize the aciverse reaction potenticl of the waste during handling and storoge.

Combustible waste is one of the largest volumes of waste generated throughout any fuel cycle activity. It is generally accepted that this waste should be incinerated, and the volume thereby reduced, for three reasons:

1) Radiolysis of the hycrocarbons can release hydrogen during storage

2) The waste represents a large combustible fuel loading and, therefore, a fire hazard

3) The waste represents a large volume of moterial that could be reduced $90-95$ volume percent

By reducing the volume, disposal costs and consequent risks would be suistcitially reouced. Numerous different incineration concepts have been proposed, including such systems as fluidized bed, acid digestion, molten solt, pyrolysis, and controlled air incineration, and are subjects of a separate report.

A large percentage of solid waste results from the conversion of liquid wastes to solid form. Low-level liquid waste is processed through a typical waste disposal facility bosed upon clariflocculation, filtration and evaporation technology. Approximately 99 percent of the rodiooctivity is removed during such processes, and the resultant sludge can be either dried to a solid or mixed with an appropriate agent to form a solid matrix.

The gerierol policies governing the treatment of liquid wastes and sludges are that sludges/liquids should be converted to a solid low-leachable form and thot the waste should be converted to a form acceptable for dispasal since, once solidified, further treatment is difficult, if not nearly impossible. Various DOE programs are underway for the treatment of this waste to reduce the generation and volume of the waste, decontominate the liquid waste, remove radioactivity where proctical, and convert the waste to a solid form. 10,57 
Noncombustible waste has the potential for significant resource recovery volue; not for recovery of the octinide material, but rather, for the recovery of the metals. Typically, the metals include materials used during construction and processing and in shielding. Further, contaminated material waste olso results from the nuclear fuel cycle fabrication and, in particular, the cladding hulls. Various programs ore in the process of developing technologies to treat contarr.inated metal wastes. Such programs include decontamination by either chemical or physical means (such as smeiting) as well as aqueous and molten salt decontamination and melt slagging processes. 10,57

Given the "os generatea" waste sources, it is then necessary first to develop a methadology for evaluating the final waste form characteristics which are desirable and then to develop a means of achieving them. Technologies to be considered will include those which can convert "as-generated" raw waste to an acceptable waste form, and those which can provide a means of immobilizing this waste form. Thus, volume reduction techniques would be considered for solids and liquids, and as a means to immobilize this material.

It is necessary to evaluate these treatment technologies and thus develop a waste form which will be acceptable to the waste repository. In addition to the waste form, it is necessory to evaluate the woste conteiner and thus the entire waste package. The waste container designed must be compatible with the final waste form as well as with any criterio developed by the repository concerning size, configuration, handling, etc., of the container into which the waste is placed. Transportation and personnel handling risk must also be evoluated.

The overall methodology must consider the various interactions between the desirable features of an ideal waste form and the practical problems of a nearly infinite number of potential waste materials which must be hondled, and the practicalities of utilizing advanced technologies to treat such waste. Further, the waste container (and package) must be clearly defined to ensure the possibility of retrieval if this is deemed one of the criteria. 


\subsection{TRU CONTAMINATED WASTE CONTAINERS}

The purpose of this section is to provide an overview of the waste containers being used to dispose of TRU contaminated waste. This section will briefly review container design, regulations governing containers, and identification of waste form factors affecting a TRU waste container. Section 4 will provide the detailed dato base for these containers.

\subsection{INTRODUCTION}

TRU waste containers and radioactive woste containers hove evolved to fill a need ss the need arises. Indeed, only with the creation of the Department of Transportation (DOT) in 1966 has the waste containers testing, certification, and licensing effort stabilized. Even with DOT regulating rodiooctive waste containers, at least 20 different waste containers hove been or are being used to dispose of commercial and DOE-generated TRU woste. The current DOE regulations concerning the handling of TRU contaminated dry wastes require packaging and burial/storage that the containers can be retrieved intoct and contamination-free for a 20 -year period.*

Vorious criterio must be considered in the selection of a container for a variety of TRU waste materials and runctions. In certoin cases, the container may be used as a process vesse! (e.g., in solidifying wastes by using cements, ureaformaldehyde resins, bitumen or other similar materials). Container design is important in meeting the requirements for transportotion of solidified waste packages, interim handling, depository design for disposal and consideration for retrievability, if this is deemed necessary. The container should provide radiation shielding, if required. and be of sufficient integrity to minimize the probability of container breach due to hondling or transportation accidents. The

\footnotetext{
* Presently proposed WIPP criterio only require o 10-year life. ${ }^{39}$
} 
purpose of the container is to provide ease of handling and minimal personnel expciure, and to prevent loss of activity from the pockage prior to burial. The containers may also provice a turrier to radionuclide release from the waste form in burial; though little credit has been given to the contciner once the woste package is buried. This is the result of a lack of a proven long-lived engine .ed waste container design. Though these considerctions may be imporunt for non-JRU low-level waste, the long half-lives of some TRU radionucliaes make such considerations meaningless over on extended time period. If retrievability is o requirement, the period of retrievability must be considered in the contoiner design life.

Design guidance for woste containers is essentially limited to regulations published in 10CFR - Parts, 20,70,71 and 73, 49CFR - 173.391 through 173.3.5, Fogulotory Guide 7.4 "Leakoge Tests on Packoges for Shipment of Raciocctive Miaterials:" Regulatory Guide 7.6 "Acceptable Structured inlethods for Use in Designing Large Quantity Packoges;" Regulatory Guide 7.8 "Laad Combinations for the Structural Analysis of Shipping Casks;" ano, ANSI N14.5 "Leakage Tests on Pockoges for Shipping of Radionctive Niaterials." Other standards ore under development by a NI4 standards group sponsored by the American Insurance Association concerned with various aspects af shipping rodioactive materials.

\subsection{REGULATORY REGUIREMIENTS 41,42}

The transportation within the United States of radiogctive byproduct, source and special nuclear materials, including TRU contaminated woste, is regulated by the Nuclear Regulatory Commission. The Department of Tronsportation regulates all radioactive materials in interstate commerce. International shipments, in micst coses, are consistent with the stondords of the Internotionol Atomic Energy Agency (IAEA), with the DOT serving as the "competent outhority" for the U.S. Shipments that are neither in interstate or foreign commerce nor in oir transportation, as defined in the Federal Aviction Act of 1958, are controllect by the NRC and by various state agencies. 41 
Chapier I of Title 10 of the Code of Federal Regulations contains the rules and regulotions of the NRC, including rules and definitions relating to the issuance of generol and specific licenses for receiving, ocquiring, owning, possessing, using, and transferring byproduct material, source materiol, and speciol nuclear moteria'.

The ports of Title 10, Chapter I that most directly pertain to radioactive material transportation are Parts 20,70,71, and 73, which deal with "Standards for Protection Against Radiation," "Special Nuclear Material," "Packoging of Rodioactive Materiol for Transport and Transportotion of Radioactive ivloterial under Certain Conditions," and "Physical Protection of Plonts and Materials," respectively.

The NRC, through formal agreements with certain "ogreement states," tronsferred to those states the regulatory authority over byproduct material, source moterial, and subcritical quantities of special nuclear material. These agreement states are Alabomo, Arizono, Arikansos, Colifornia, Coloredo, Florido, Georgia, Idaho, Kansas, Kentucky, Louisiano, Maryland, Mississippi, Nebruska, Nevoda, New Hompshire, New Mexico, New York, North Carolina, North Dakota, Oregon, South Carolina, Tennessee, Texos, and Washington. These states hove adopted a uniform set of rules requiring an intrastate shipper of radioactive materials to conform to the DOT requirements for packoging, labeling, and marking.

The DOT, uniter the Department of Transportation Act of 1966, the Transpoitation of Explosives Act, the Dongerous Cargo Act, the Federal Aviation Act of 1958, and the Transportation Sofety Act of 1974, has regulatory responsibility for sofety in tronsportotion. The DOT regulations governing carriage of radioactive materials by rail and by common, contract, or private carriers by public highwoy are found in 49 CFR $171-179^{*}$ The DOT regulations

\footnotetext{
* Presently being revised as illustrated by DOT proposed reçulation 49 CFR Parts 127, 171-177, Federal Register, Vol. 44, No. 5, January 8, 1979, and Vol. 44, No. 160, August 16, 1979, and No. 161, August 17, 1979 (see Appendix F).
} 
regarding porkaging of radjooctive materials are found in 49 CFR 173, "Shippers--General Requirements for Shipments and Pockagings," and 178 . "Shipping Contoiner Specifications;" they are consistent with the APR guidelines in 10 CFR 71. The DOT regulations governing the carrioge of rodiooctive materials by air ore in 49 CFF 175, "Corricge by Aircratt." The LOT regulations in $49 \mathrm{CFR}$ lió, "Corriage by Vessel," apply to the corriage of radioactive and other hazardous materials by barge or ship.

In order to ccrry out their respective regulatory functions for the safe transport of rodioactive materials with os little duplication of effort as possible, the Interstate Commerce Commission (ICC) and the $A E C$ (now the NRC) signed a "memorandum of understanding" in 1960. It has been superseded by a revised memorondum: of understanding between DOT and AEC signed on Niarch 22, 1973. Accoroing to the memorandum, the DOT regulations (49 CFR $171-179$ ) concerning packaging, marking, and labeling apply to shippers, and the regulations concerning vehicle placarding, loading, storage, monitoring, and accident reporting apply to carriers. All packagings for shipment of fissile materiol or for Type $B$ or large quantities of radioactive material require approval by the NP.C. In case of a tronsportation accident, incident, or suspected leakage from a package of radiooctive material discovered while in tronsit, the DOT investigotes the occurrence and prepares an investigation report. If, however, an occicient or incident occurs, or suspected leakage is discovered other than during fronsit, the occurrence is investigated by the NRC.

\subsection{REGULATIONS DESIGNED TO ENSURE ADEQUATE CONTAINMENT DURING TRANSPORTATION}

The regulations to be discussed below provide standards for pockaging and define limits for the packoge contents. The terms "package" ana "packaging" are defined in 10 CFR 71.4 , "Definitions," os follows:

(k) "Packoge" means pockoging and its rodiooctive contents; 
(I) "Packoging" means one or more receptocles and wroppers and their contents, excluding fissile ma.eriol and other radioactive material, but including obsorbent material, spacing structures, thermol insulation, rodiation shielding, devices for cooling and for absorbing mechanicol shock, external fittings, neutron moderators, nonfissible neutron obsorbers, and other supplementory equipment.

The present criteria provide assurance that packoging designed to meet such standards can be carried on all modes of tronsport and will withstand the conditions likely to be encountered in accidents. As developed, the criterio spe -ify tests of pockaging which can be corried out either in the laboratory or in the ield with conventionol and reodily avoilable equipment and facilities. The criter 1 were bosed on a detailed analysis of normal and accident conditions in transpart and nearly 30 yeors of experience in shipping many types of rodiooctive materiols. See Appendix G.

To meet the regulatory standards, packeging must be designed and constructer to provide lwo and, in some coses, three levels of protection. The pockoging must function in the normal tronsportation environment with a high degree of reliability. Systems selected to achieve the basic design functions (i.e., containment, shielding, heat dissipation, and nuclear criticality safety) must provide a high degree of inherent safety under normal conditions and have a high folerance for malfunctions, off-normal conditions, and ascidents, should they occur. Each shipping container is checked routinely to assure that the "as built" high quolity is maintained throughout its lifetime.

The type of pockoging is specified in DOT regulations, 49 CFR 173, occoraing to the type and quantity of rodiooctive material. Rodjooctive materials are divided into two broad closses: (I) "special form" which is a massive, non-friable, solid material or moterial confined in a high integrity copsule of inert moterial, and (2) "normal form" which applies to all radiogctive materiols which ore not "specinl form." Normol form rodionctive materials cre clossified into seven groups of rodionuclides bosed primarily on radiotoxicity of the rodionuclides. Pockage limits for the seven transport groups and "special form" ore shown in Table 3-1. 
TABLE 3-1

TYPE A AND TYPE B PACKAGE QUANTITY LINITS

\begin{tabular}{ccc} 
TRANSPORT GROUP & $\begin{array}{c}\text { TYPE A QUANTITY } \\
\text { (Curies) }\end{array}$ & $\begin{array}{c}\text { TYPE B QUANTITY* } \\
\text { (CURies) }\end{array}$ \\
\hline I & 0.0001 & 20 \\
II & 0.05 & 20 \\
III & 3 & 200 \\
IV & 20 & 200 \\
V & 20 & 5,000 \\
VI, VII & 1,000 & 50,000 \\
SPECIAL FORM & $20 * *$ & 5,000
\end{tabular}

"Quantities exceeding Type B are "large quantities (large racioactive source).

** Except for Californium-252, wherein the limit is z curies. 
inuch of the moterial that is TRU wastes is sufficiently innocuous to be classifiec as low-specific-cctivity (ISA) niaterial. ${ }^{5}$ If the rodioactivity is essentiolly uniformly distributed, with a concentroticn of no: more thon 0.1 $\mu \mathrm{Ci} / \mathrm{g}$ of Group I material (such as plutonium), or $5 \mu \mathrm{Ci} / \mathrm{g}$ of Group II material (such as strontium-50), or $30 \mathrm{\mu Cl} / \mathrm{g}$ of Group III or IV materiol (such os cesium137 , the moteriol qualifies as LSA waste. Also included ore objects with a sinall specified amount of externol radioactive contamination.

For tronsport by non-exclusive-use venicles, such motericls must be contcined in pockoging meeting Type A requirements. For exclusive-use vehicles, bulx shipment is permitted if the activify is less thon a specified small fraction of the LSA linit or otherwise in strong, tight pockenes that will not leak in normal tronsport. Ordinary drums ana boxes generolly qualify as strong, tight pockages thot will not leak in normal tronsports. Disposoble concrete containers are also used.

If the total number of curies in a pockoge exceeds a Type A quantity or if more than a specified small omount of fissile moterial is present Type $\Delta$ paciroging requirements moy be applicable.

\subsubsection{TYPE A PACKAGING}

To quolify for tronsport, any packcging used to contoin rodiooctive material must meet the general requirements of 49 CRF 173.3\%3, "Cenercl Pockaging and Shipment Requirements." These requirements stote, omong other things, that the packaging must be adequate to prevent loss of dispersal of the rodioactive contents and mointain the radiotion shielding properties for the normal conditions encountered during transport. Tests to simulate normal transport conditions ore outlined in 49CFR 173.398 (b), "Stondords for Type A Pockoging," ano in Appendix A to 10 CFR 71 , "Normal Concitions of Transport."

In 49CFR!78 there are descriptions of various DOT-approved containers for Type A pockoging, including carboys, fiberboard boxes, steel drums, etc., that moy be used without specific regulatory approvol. hewever, in a recent regulotion, DOT 
eliminated the various "hardwore-oriented" specifications for the Type A package coniciners listed in 4.CFI. 173.394, "Rodiooctive woterial in Speciol Form," and 4.CFP.173.395, "Radiooctive Material in Normal Form," and ruled that each Type A packoge presented for shipment must be certified accorcing to the Type $A$ "Specitication 7A" design with a supporting safety anolysis. The requirements for this design ore specified in 49CFR/78.350, "Specification 7A; General Pockaging, Type A." The use of existing Specification 55 (as described in the former $49 \mathrm{CFR}$ (78.250) contoiners is also outhorizeo for Type A shipments, but the construction of adoitional Specificotion is containers after irarch 31 , 1975 , has been prohibited. Foreign-made pockagings, properly lobeled as Type $A_{1}{ }^{\prime \prime}$ are also acceptable by DOT for use in domestic tronsport (49CFR $173.394(0)(4)$ and $173.395(0)(4)) .^{41}$

\subsubsection{TYPE B PACKAGING}

Qucntities of radioactive rioterial greater than the Type $A$ limits can de transported only in Type $B$ packoging. A Type $B$ pockaging is ciesigned to meet more stringent standards and hence is considerably more accident resistont then a Type A pockaging. In addition to meeting the standards for a Type A packoge, a Type $B$ packcge must also be oble to survive certoin hypothetical accident conditions with essentiolly no loss of containment and limited loss of stielding copability. The NRC pockaging stondards are given in Subpart $C$, "Pockage Standards," of 1OCFR7I, and the tests to simulate accident conditions are found in Appendix 9 to IOCFR7I, "Hypotheticol Accident Conditions." A Type $B$ pockaging design requires NRC approval before it can be used for shipping radiocctive moterial.

The Type $B$ quantity limits are somewhat artificial in that the regulcitions permit shipments of quontities greoter thon these limits as "lorge quantity" sniprrents in Type $B$ containers. Like the Type A limits, Type $B$ limits hove their origin in the earlier IAEA regulations.

The types of packaging occeptable to DOT for Type $B$ quantities, listed in $49 \mathrm{CFRI} 73,394$ and 49CFRI73.395, are summarized in Table 3-2. 
TABLE 3.2

TYPE B PACKAGING PERMITTED BY DOT FOR TRANSPORT BY 49 CFR 173.394 AND 49 CFR 173.395

\section{Special Form}

1. 5 peec 55 (300 Ci imox.) (49 CFR 179.250)

2. Spec 6 in ( 49 CFR 178.104)

3. NRC (AEC) approved per 10 CFR 71.

4. Type B pockoging meeting 1967 IAEA regulations for which foreign competent outhority certificote has been revalidated by DOT.

5. Spec 20WC (49 CFR 178.194) outer jacket with snug-fitting Spec 7A (49 CFR 178.350) or existing Spec 55 inner contoiner.

b. Spec 2I WC overpack with single inner Spec 2R (49 CFR 178.34) or existing Spec 55 inner package securely positioned and centered.

\section{Normal Form}

1. Spec 6M (for solid or gas only which does not decompose up to $250^{\circ} \mathrm{F}$ ).

2. NRC (AEC) approved per 10 CFR 71 .

3. Type $B$ packaging meeting 1967 IAEA regulations for which foreign competent outharity certificate has been revalidated by DOT.

4. Spec 20WC jacket with snugfitting inner Spec $2 R$ or existing Spec 55 inner package. For liquid, 173.393(g) must also be met for the inner pockoge. 
Certain types of sources, particularly irradiated reactor fuel elements, irrodiator and teletherapy sources, and most plutonium shipments, contain quantities of radioactive materials in excsss of the Type $B$ limits. Pockaging for lorge sources is subject to the requirements for Type $B$ pockoging plus odditional requirements related primorily to decay heat dissipation (49CFR/73.393(e)). The DOT packaging requirements for lorge quantities of normal-form moterial ore stated in 49 CFR $173.395(\mathrm{c})$.

\subsubsection{PROPOSED CHANGES TO TRANSPORTATION REGULATIONS}

As discussed in Appendix F, proposed changes to 49 CFR 127, 171-177, and similar proposed changes to 10 CFR 71 will eliminate the seven transport groups and establish curie limits on each radionuclide based on its own toxicity. In Appendix $F$ where these changes are discussed it is stated that one of the effects of this change will be to increase the quantity of less toxic members that con be snipged in a given container. Other changes are a revised definition of LSA material and a new classification called "low level solids (LLS)." The changes to the LSA definition will essentially eliminate bulk liquid shipments os LSA materiol. For both the LSA and the LLS categories the specific activity limits ore tied to the individual isotopic curie limits. Furthermore, the LLS definition considers the leachability characteristics of the: solidification agent used to immobilize thr radioactive waste. Under these revised regulations most of the LLS material would be shipped as Type A moterial rather than LSA os in the past.

These changes may impact the transportation of TRU wastes and thus the packoges must reflect not only the disposol requirements but also any unique restrictions imposed by woste tronsportation.

\subsection{TRU CONTAMINATED WASTE CONTAINER DESIGN $42-44$}

In addition to regulations concerning transportation and handling during transportation discussed briefly above, ather factors must be cinsidereo in the design and develapment of a waste contoiner for TRU waste. 
The DOE requirements for a 20 -year contamination-free storage period (ofter which time the container will be snipped for disposal to a federal repasitory) establisin design criterio for material of construction ond identify the importance of ensuring waste form/waste container compotibility. Also established are the requirements for additional handling during the tronsport to the repository, for subsequent handling, and for possible retrieval from the repository at a later date. With regard to hondling, the container design must consider the follov ing:

- Damage to the container

- Handling methoo's

- Radiation dose to personnel

- Transportation activities

- Storage-related activities

- Retrievability from interim storoge and possioly from the repository

- Contamination

- Repackaging of failed containers

Container integrity is the critical factor for TRU woste containers. Basically, three factors must be controlled:

- Internal container degradation

- External container degradation

- Container closure

Deterioration of the container, which occurs as a result of reactions with the contained wastes, must be limited to assure the survival of the waste container and pockoge. Limiting deterioration con be accomplished by controlling detrimental interactions between the wastes or their decomposition products and the total package (primary container plus liner or pnckage coating). The processes that could cause deterioration include: 
- Corrosion

- Radiolysis

- Pyrolysis

- Chemical attock

- Biological interactions

Due to the diverse materials in the waste matrix, assessment of potential interactions is complex; und the solutions are currently uncertoin. Appenoix $\tilde{E}$ presents a detailed discussion of the limited data which have been identified.

Corrosion of the pockoge from an internal source may be a major proolem for some waste form $t /$ pes. If external moisture is prevented from entering the package, dry inert materials, such as some types of building debris an.t equipment, should require only structural strength and resistance to external corrosion in packaging to meet the requirement for interim storage, os well os during the retrieval period ot the waste repository. Other woste moterials, however, have been shown to be incompatible with the containers which hove been previousiy used for storage. At LASL, sludges from the liquid waste treatment plant have accelerated the in: errial corrosion of unprotected mildsteel drums to cause leakage within one year. ${ }^{44}$ Corrosion could also result from ocid or other chemicals absorbed from the waste materials. $47-49$

Many internal corrosion problems could be eliminated, or at least moderated, by using some inner liner or chemical-resistant packoge coating between the waste and the outer contciner. Several DOE sites employ some form of internal protection in an attempt to limit corrosion of the primary container. An alternate solution might be the use of a corrosion-resistant primary container, such as a polyethylene or fiberglass drum. Because of its potential comoustibility, this type of contoiner would probobly be restricted to uses involving noncombustible materials and might require a separate starag? area from the combustible wastes. Alteration of corrosive wastes to a more inert form might be the most desiroble solution, and indeed, ORINL has utilized stainless steel drums for certain TRU wastes. 
The problem of interaction with the container is not limited to the wastes alone, but also encompasses the products of the degradation of these wostes. Major sources of decomposition include radiolysis and pyrolysis, though the extent of the potential problem from .hese processes connot be fully assessed at this time. The products of radiolysis of materials (such as cellulosics, plastics, and water) are known; but the experiments were usually performed using gammo or neutron irrodiation. The effects of alpho rodiation, with its high energy disposition and limited penetrability, on systems such as these have not been well investigoted. 4,45

Studies of pyrolysis have demonstrated the production of gases and smoke at temperotures above $150^{\circ} \mathrm{C}$ for typical combustible waste materiols (cheesecloth, latex, polyvinyl chloride, polyethylene). ${ }^{44}$ Problems of heating may arise from self-heating of the transuranic contaminants, particularly Pu-238.

The products of both radiolysis and pyrolysis may include toxic, corrosive, and flammable gases. Polyvinyl chloride produces $\mathrm{HCl}$. Polyethylene produces predominantly hydrogen during radiolytic degrodation, while cellulosics produce various combinations of flammable hydrocarbons and organic acids. Whether these products ore produced in sufficient quantities to prove hormful is uncertain, but will depend upon the waste material present. A potential problem associated with such decomposition is the possibility of a breach in the pockage due to pressurizotion through gas production. In particular, the possibility of pressurization hoving occurred must be considered at the time of retrieval, whether or not breaching occurs; and coution must be exercised to ovoid spread of contamination, expecially if the waste material is to be repackaged or processed at that time.

The packaging system must inen be selected for the porticular woste type, based upon the potentially detrimental components of the waste matrix and the possible decomposition products. Other guidelines require exclusion of certain materials (such os acids, oxidants, and corrosive chemicals) from the waste matrix to decrease the chances of unfavorable interactions with the package. While the initial specifications derived to assure compliance with this guideline are likely to be based upon existing woste types, packaging materials, and 
processing techniques, consideration must be given to the development of new processing techniques which could produce other types of woste with different corrosive properties.

If the waste container and package are to survive the interim storage period, both before and after disposal in the waste repository, steps miust be aken to protect the package from external influences (including corrosion of metals, aging of plostics, or the decomposition of materials such as fiberboard and wood) which might couse deterioration.

The inability of certain combinations of package and storage environment to meet retrievable storoge requirements has been demonstrated. For example, 208-liter mild-steel drums in shallow earth burial have been breached by the corrosive oction of the soil in less than 20 years. ${ }^{47-49}$ Predictions of drum lifetimes in such an environment have been given as 3-7 years. Information on the effects of earth burial as a storage environment upon wooden or plostic packaging materials is not currently available, but on untreated wooden package would not be expected to survive under such conditions in many environments.

The degree and rate of degradation of a packaging material will be dependent upon the material used, any auxiliary protection offorded by a protective cooting, and the environment in the storage focility. Specifications selected for any one of these three foctors moy decrease the need for limitation of the other two.

Selection of the actual packaging material must be carefully considered in relation to the storage environment. For example, a wooden box in a damp environment may decompose rapidly, while the same box in a drier, controlled environment may last for many years. On the other hand, if the environment of the box is too dry, cracking of the wood may occur. Similarly, an unprotected mild-steel drum will undergo rapid corrosion in a damp atmosphere. Unrelieved stress in the currently used steel drum has been shown to be an important factor in the rate of corrosion of parts of this contciner. 44 In this respect, any minor damage (such as denting of a steel container during hondling, transport, or 
storage operations) may be significant to the survival of the pockoge during the interim storoge period.

In the situations described above, some degree of protection may be obtained by using preservatives for woods and points or other coatings for any container materiais. In fact, the steel drums used today for waste containment do have on outer cooting of corrosion-resistant paint, though the paint is often badly chipped or scrotched during drum handling. When the coating is undamaged, it has been found to give good long-term protection, even in the more corrosive environment of earth burial. Wooden boxes, used by Rocky Flats for storoge of retrievable wastes of $\mathbb{N E L}$, are provided with a fiber glass outer coating as o mecns of protection from externally-coused pockage degrodation. Under conditions where a completely undamaged outer coating of known corrosion resistance could be guaranteed, less emphasis would need to be placed on the construction of the contailier and on control of the storoge environment.

The tightness of the closure mechanism on o waste container is important to the package integrity uring handling and storage of retrievable transuranic waste. Radiological health and safety considerotions during handling, transport, and storage distate containment of contamination. It is recognized that some contoiners $r e$ complex in design, with sealed inner containers to provide the containment barrier and with outer contoiners to serve as protection for the inner container. In any case, seal tightness should provide the protection needed to prevent any spread of contamination during handling, transport, storoge, and retrieval.

Considerations requisite to on airtight seal would include eliminating breathing of the pockage which results in possible spread of contamination, moisture intake leoding to corrosion, und possible escape of flammable gases.

During temporary storoge and tronsport, variations in temperature and elevation can couse pressurization and depressurization of container by as much os $\pm 14 \mathrm{kPo}$ under certain possible conditions. Gosketed closures on currently used DOT $17 \mathrm{C}$ or $17 \mathrm{H}$ mild steel drums will not hold on internal pressure of $34 \mathrm{kPa}$ for 
any significont period of time. Tinus, pockoge breathing does present the potential spread of contamiration by contamination ascoping during the "exhale" cycle. During storage with relatively constont pressure and temperature, one would expect a minimal breathing effect. Degrodation of cellulosics and plastics, however, might produce sufficient volumes of gas to provide a potential vehicle for contamination to escape from the contoiner.

In the cose of moisture intake from a humid environment by breathing tnrough o closure, corrosion could vory with different container designs, depending on the relationship between the outer container and the inner liner. In the case of the mild-steel drum with a heavy liner, condensation in the annular space could provide a condition for crevice corrosion. Although the heavy liner moy be considered the primary contoiner in this case, retrieval of packages with a badly corroded outer container could be difficult.

The most complex consideration relotes to gas formotion in storoge containers. Regordless of exclusions of certain chemicals and waste types (such os pyrophorics), there will be some chemical contamination of the bosic waste types. Decomposition of waste materials, in particulor the combustibles, through mechanisms such as pyrolysis, rudiolysis, and chemical attack, can result in gas formation. The quantity of transuranic elements, packing density of the waste material, waste matrix, . Jture of chemical contaminants, and ambient temperature will have an effect on the type and rate of such gas formation.

If the container is to be tightly sealed (cirtight), then it would have to be designed to hold whatever pressure develops during the total storage and retrieval period. Because of the variables stated obove, this pressure is difficult to determine. As a related problem, should an external fire develop neor pressurized drums, even greater pressures developed by the heoting would increase the probability of rupture, adding flammable gases as well os the contents of the pockoge, if combustible, to the existing fire. This resulting increase in fire-looding external to the package could significantly increose the potential for fire spread. If the container is not airtight, gases could leak into the storage area environinent, producing a potential fire condition from flammoble or explosive gases. Depending on the rates of gas formation, ventilotion 
of the storage facility may be required. The conflicting orguments provide odditional support for the elimination of combustibles in storage, but further studies ore needed to more clearly define these problems.

From a practical standpoint, attoinment of an airtight container design appears difficult by any means other than a welded closure. Even with improved gasket designs, a seal that will hold required pressures now will not necessarily survive the -toroge and retrieval period. Further, the quality control program required to assure the seal on each package could be excessive, if not impossible.

Many of the oforementioned problems can be eliminated or cuntrolled, depending upon the criterio established for the final TRU waste form.

Given these general requirements, a waste container design should incorporate acceptoble:

- Pockoge identification methods

- Design criterio to reflect expected quantities of TRU isotopes and potentiol impact of criticality, self-heating, gas generation, etc.

- Material of construction for the storage and final disposal* environment (including external and internal environments)

- Leakage prevention requirements

- Shieking requirements (or capability to utilize overpack)

- Goskets and closure materials and design conditions

- Handling methods

Given an adequate design, tha fabrication, inspection, testing and quality control/quality assurance steps necessar" to implement the design must be established.

* Retrievability should be considered, if required. 


\subsection{TRU CONTANIINATED WASTE CONTAINER DATA BASE}

The purpose of this section is to establish o contciner charocterizotion data bose for UOE and commercial TRU waste containers.

\subsection{WASTE CONTAINER CHARACTERISTICS AND DESCRIPTIUW}

\subsubsection{DOE WASTE CONTANNERS}

A survey of waste containers utilized by DOE controctors revealed the extensive number of contoiners/packoges utilizeo (see Tobles $4-1$ and 4-2).

At present, more than 18 different packaging configurations are being used for interim storoge of DOE low-level TRU wostes. 1,45 Of these, onty the DOT I7C steel drum and the $1.2 \mathrm{~m} \times 1.2 \mathrm{~m} \times 2.1 \mathrm{~m}-4 i 7 \mathrm{~A}$ plywood box ore recolily acceptable for direct shipment and isolation in the current design of WIPP, 39,40 The proliferation of waste packages currently in use is a cirect result of efforts of the various waste generators to package their unique TRU wastes into containers able to meet the 20-year retrievaivility requirements under the differing consitions of on-site waste processing and storage. Completing the criteria, development of standardized TRU woste containers will be difficult without established parameters regarding waste form anc interim and final storage environment. In the selection of materials for construction of a porticular packoging system, it is important first to consider the characteristics of the system, giving special attention to extroneous foctors that may influence decomposition. Since these foctors would be peculiar to a particular system, it may be impractical to offer hard and fast rules that would cover all situations. Table 4-3 presents a compilation of various TRU waste pockages in use."

The containers currently in use at vorious DOE and commerciol fucilities fall into three general categories: 118 -liter (30 gallon) and 208-iiter ( 55 gollon) steel drums; large fiberglass reinforced polyester (FRP) plywood boxes; and large carbon steel boxes. These latter containers have capacities in the range of 0.23 $43 \mathrm{~m}^{3}\left(8-1500 \mathrm{ft}^{3}\right)$. Depending on the materials being shipped (i.e., the types of 
TABLE 4-1

RESLLTS OF WASTE CONTALIVER SLRVEY OF DOE WASTE GEIVEFATORS ${ }^{45}$

Type Á Pcckcges

1. Hietal Drums (DOT Regulation)

Spec. 5B (178.82)

Spec. 50 (178.84)

5pec. бa (178.87)

Spec. ó 6 (178.98)

Spec. 6C (178.95)

Spec. ód $(178.100)$

Spec. ók (178.101)

Spec. ól (178.103)

Spec. ódi (178.104)

Spec. $17 \mathrm{C}(178.115)$

Spec. $17 \mathrm{H}(178.118)$

Spec. 42B (178.107)

Spec. $42 \mathrm{C}$ (179.108)

2. Fiber Drums

Spec. $21 C(178.224)$

3. Wooden Eoxes

Spec. 14 (178.165)

Spec. I5A (I78.1 6́)

Spec. 15E (178.169)

Spec. 15C (178.170)

Spec. 150 (178.171)

Spec. 19A (178.150)

Spec. 19日 (178.191)

4. Fiberbocrd Boxes

Any Spec. 12 Series

(178.205 to 178.212)

(90 kg test minimum)

Spec. 23F (178.214)

Spec. 23H (178.219)
Vumber of Users

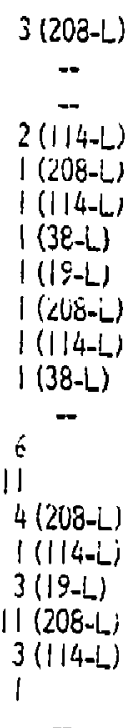

5

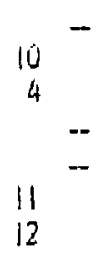

$1(12 A)$

$12(128)$ 


\section{TÁÉLE 4-1 \\ (COivi.)}

Iype A Pocrages

Iumber of Users

5. Cylinders

Any Spec. 3 Series

i) (SF, SARA)

Any Spec. $\$$ Series

(178.47 to 176.58)

o. Spec. $55(175.25)$

?

7. Spec. 7A (178.350)

iNOTE: 17 packages were listed as being used by DOE controctors under the Spec. 7 A classification.

1) Cylinders for UF,

(five sizes)

2) Strong Wooden Boxes

3) Steel Boxes

4) Fiberboard Boxes

5) Steel Drums

b) Benelex Box (neutron sources)

i) Concrete Voults 


\section{TABDiE 4-2}

DOE WASTE CUNTALVER SPECIFILATHUNS 45

\section{Contoiner Type}

I) Steel Cylincer (UF $F_{0}$ ) (five styles)

2) Brookhoven's Concrete Voults

3) Argonne's Steel Zox

4) OPINL's 7A Pockoge

5) Eattelle Columbus Steel Eox

6) Wooden Eox

\section{DUT Specificoticn}

Spec. 7 A

Spec. iA

Spec. IA

Spec. $7 \mathrm{~A}$

Spec. TA

Spec. $198-150$

lone size $5|\times 5|$

$x 51 \mathrm{~cm}$.)

(Note: Comments

in Phose II Summary

Report)

Spec. $6 \mathrm{M}$

Spec. oL (208-liter)

Spec. $42 E$ (208-liter)

Spec. 6.J (208-liter)

Spec. 17C (208-liter)

Spec. 17H (208-liter) 
TABLE 4-3

TRU LOW-LEVEL WASTE PACKACES IN USE ${ }^{\prime \prime}$

\section{Package Description}

208-L stee' drum, DOT 17H, zinc dipped, polyethylene (PE) bog liner

exterio: painted, PE bog liner

208-L steel d: um, DOT $17 \mathrm{C}$ interior and exterior painted, 90 mil high density polyethylene (HDPE) liner; lead shielded (aptional)

PE bag liner, 2 each inside concrete cosk

Corruggoted metcl pipe, zinc dipped, $0.76 \mathrm{~m}$ diameter $\mathrm{x}$

$6 \mathrm{~m}$ long

0.21

208-L steel arum, DOT I7C zine dipped, $90 \mathrm{mil}$

114- L stainless steel drum, $P E$ bog liner

208-L steel drum, zinc dipped, 90 mil HDPE liner, inside concrete culvert

Welded steel box, $3 \mathrm{~mm}$ thick, PE bag liner, random sizes, will fit inside supertiger

Random

Fibergloss reinforced polyester (FRP) plywood box, $1.2 \mathrm{~m} \times 1.2 \mathrm{~m} \times 2.1 \mathrm{~m}, \mathrm{PE}$ bog liner

FRP plywood box, random sizes, PE bag liner

Steel bin, $1.2 \mathrm{~m} \times 1.5 \mathrm{~m} \times 1.8 \mathrm{~m}, 12$-gouge, $166-\mathrm{L}$ DOT $17 \mathrm{H}$ steel drums or I" thick plywood box placed inside

FRP plywood box, rondom, steel drums inside

Random

FRP plywaod boxes, cold rolled steel boxes, inside concrete culvert 
radionuclides and their gross activities/ transportation regulations may require thot these containers be shipped with either overpceks or inner liners to provicie additional mechanical integrity and/or rodiation shielding.

In addition to the woste contoiners themselves, it is necessary to consider other aspects of transportation and handling, particularly container limitations estoblished by the U. 5. transportotion system and potential limits at the federal waste repository, Table 4-4 presents certoin physical limitations which have been identified.

There are currently three predominant methods of transporting TRU cantaminoted waste to o waste repository:

- ATNIX Roilcors - 500 and 600 series

- Super Tigers

- Poly Ponthers

Both the AiviTX 500- and 600-series roilcars are mossive, oovible-wolled steel railcars which provide the equivolent protection of a DOT Type d pockoge.

The AivTX-600 achieves ropid looding and unlooding of the $2.7 \times 2.7 \times 15.2 \mathrm{~m}$ cargo space by pre-packaging the TRU woste into stondard $6 \mathrm{~m}$ steel cargo containers. The AT ivX-600 roilcar will hold two cargo containers, each carrying seventy 208-liter drums and up to 20,364 kg gross weight. The AinTX-500 is a railcar which does not use inner cargo containers. The ATiWX-500 is divided into three inside boys hoving dimensions of $4.9(1) \times 2.8(w) \times 1.9(\mathrm{~h})$ meters. Drums are typically polletized to fccilitate loading and unloading. A typical load consists of 128208 -liter arums (however, spoce can occommodate 192 drums), twelve fiberglass boxes $(1.2 \times 1.2 \times 2.1 \mathrm{~m})$, or a combination of palletized drums and boxes.

A Super Tiger is on overpock authorized for Type A, Type B, and "Lorge Quantities" or radiooctive materials hoving outside dimensions of $2.4 \times 2.4 \times 6 \mathrm{~m}$. iviaximum poylood is approximately $13,045 \mathrm{~kg}$ with o gross weight of $20,455 \mathrm{~kg}$. 
TABLE 4-4

MAXIMUM DIMENSIONS THAT MUST BE CONSIDEREO FOR WASTE CONTAINER DESIGN"

Dirnension

Inside Length

Inside Width

Inside Height

Door Width

Door Height

\begin{tabular}{l}
$\frac{c}{\text { ATMX }}$ Railcar \\
\hline $600 \mathrm{in.}(5.24 \mathrm{~m})$ \\
$108 \mathrm{in.}(2.74 \mathrm{~m})$ \\
$108 \mathrm{in.}(2.74 \mathrm{~m})$ \\
Top Load \\
Top Load
\end{tabular}

Top Load

\begin{tabular}{c}
$\begin{array}{c}\text { Super } \\
\text { Tiger }\end{array}$ \\
\hline $172 \mathrm{in.}(4.37 \mathrm{~m})$ \\
$76 \mathrm{in.}(1.93 \mathrm{~m})$ \\
$76 \mathrm{in.}(1.93 \mathrm{~m})$ \\
$76 \mathrm{in.}(1.93 \mathrm{~m})$ \\
$76 \mathrm{in.}(1.93 \mathrm{~m})$
\end{tabular}

228 in. $(5.79 \mathrm{~m})$

93 in. (2.36 m)

$91.5 \mathrm{in} .(2.32 \mathrm{~m})$

$90 \mathrm{in.}(2.29 \mathrm{~m})$

$89.5 \mathrm{in.}(2.27 \mathrm{~m})$

$\begin{gathered}\text { WIPP } \\ \text { Hoist Cage }\end{gathered}$
$144 \mathrm{in} .(3.66 \mathrm{~m})$
$96 \mathrm{in} .(2.44 \mathrm{~m})$
$108 \mathrm{in} .(2.74 \mathrm{~m})$
$96 \mathrm{in} .(2.44 \mathrm{~m})$
$108 \mathrm{in} .(2.74 \mathrm{~m})$


The Poly Ponther is o rectongular overpock out - vrized for Type A and Type $B$ rodioactive materials having outside dimensions of approximately $1.9(1) \times 1.7(\mathrm{w})$ $\times 2.3$ (h) meters, ilaximum poyload is opproximately $1500 \mathrm{~kg}$ with a gross weight of $2773 \mathrm{~kg}$.

\subsubsection{COMMERCIAL TRU WASTE CONTAINER}

The commercial sector is expected to follow the general lead of DOE on future waste containers. Due to the lock of data on previous TRU woste disposal proctices from the commercial sector, it con only be postulated that DOT $7 \mathrm{~A}$ containers, primarily the $17 \mathrm{H}$ and $17 \mathrm{C}$ drums (both 208-liter and $1 / 4$-liter) were utilized in conjunction with the DOT 7A plywood box $(1.2 \times 1.2 \times 2.1 \mathrm{~m})$.

The AGNS reprocessing plant hos identified the use of three mild steel drums: 114-liter, 208-liter and 303-liter. Further, a 208-liter stainless steel drum was identified os well as a clodding hulls container (doto being sought).

It appears appropriate to assume that the AGNS TFU waste containers and the DOT 7A box should cover the contairers expected to contain commercially generated TRU waste in the future.

\subsection{TRU WASTE CONTAINER SPECIFICATIONS AND DESIGN DATA}

The following doto sheets and figures hove Deen obtained from a number of sources. $8,11,21,38,43,45,48-55$

Toble 4-5 provides o list of DOE focilities and the principol container types used for TRU woste.

Tables 4-6 through 4-35 and Figures 4-1 through 4-37 present dato sheets and other information on waste containers. Appendix $G$ provides the regulations covering the tests required for these containers. 


\section{TABLE 4-5}

TRU WASTE CONTAINERS UTILIZED BY DOE WASTE GENERATORS $"$ "

\section{Waste Generotor}

Rocky Flots Plant

Honford

Mound Focility

Los Alamos Scientific Laboratory

Savonnah River Plant

Oak Ridge National Laboratory

Argonne Notional Laboratory - East

Lowrence Livermore Loboratory

Lowrence Berkeley Laboratory

Bottelle Memorial Institute

Atomics International

EG\&G Idoho

\section{Containes}

17C Drum

Plywood Box

17C Drum

Plywood Box

17C Drum

Plywood Box

114-L Drin

$17 C$ Drum

Corrugated Metal Pipe

Plywood Box

17C Drum

Plywood Bax

Steel Box

[14-L Stainless Steel Drum 17H (Stoinless Steel)

Steel Bin

I7H Drum

Plywood Box

17H Drum

Welded Steel Box

I7H Drum

17H Drum

I7H Drum

17C Drum! 


\section{DOT SPECIFICATION ÓB}

1) Common Name of Container:

Spec 68 30-Gallon (114-Liter) Steel Drum

2) Authorized Contents:

Type "A" quantities of solid radioactive moterial in normal or special form.

3) Dimensions:

Interior - 18\%/4 in. i.d. $\times 27 / 2$ in. usable height

Exterior - 19\%/2 in. 0.d. $\times$ 28-3/4 in. outside height

4) Description of Container:

Spec 6B 30-gallon (I/4-liter) open-heod steel drum

16 gauge body and head sheet

12 gouge bolt ring

$5 / 8$ in. bolt

Gasket required (see item 5)

5) Specifications and Restrictions:

Authorized Gross Weight - $600 \mathrm{lb}(272 \mathrm{~kg})$

Any bulky equipment with sharp corners, protrusions, etc., must be secusely positioned within drum.

Gosket material must have minimum operating range of $-40^{\circ} \mathrm{F}$ to $+130^{\circ} \mathrm{F}$, If sponge rubber gaskets are used, minimum of $k_{2}$-in. is required.

6) Tesi Results:

Test Results Discussion and/or Reference

\section{Environmental Conditions}

a) Heat, $+130^{\circ} \mathrm{F}$ Poss Engineering Analysis (EA) - Temperoture is within normol operating range for moterials of construction.

b) Cold, $-40^{\circ} \mathrm{F}$ Pass EA - Temperature is within normal operating range for materials of construction.

c) Reduced

Pressure

Pass

$6 \mathrm{~B}$ specificotions require passing $15 \mathrm{psig}$ leak test. CFR49 |78.98-12. 
TABLE 4-6

(CONT.)

Test Results Discussion and/or Reference

d) Vibrotion Pass Containers have withstood years of transport with no occurrences of significant damage due to normal vibration.

Test Conditions
e) Woter Sproy
Not
CFR49 173.398 (b) (3) (i)
Required
f) Free Drop
Pass
(4 ft.)
Tested with gross weight of $613 \mathrm{lb}$. "Spec 68 30-Gallon Steel Drumi:' Tech- nical Support Document - Type A Study, MILM 2229 (1975).
g) Corner Drop Not
Required
As long as packoge is Fissile Closs l or exempt. CFR49 173.398 (b) (3) (iii).
h) Penetration Pass
"Spec 68 30-Gallon Steel Drum," Tech- nical Support Document - Type A Study, MLM 2229 (1975).
i) Compression Pass
Tested with 3500-lb load. "Spec 6B 30-Gallon Steel Drum," Technical Support Document - Type A Study, MLM-2229 (1975). 


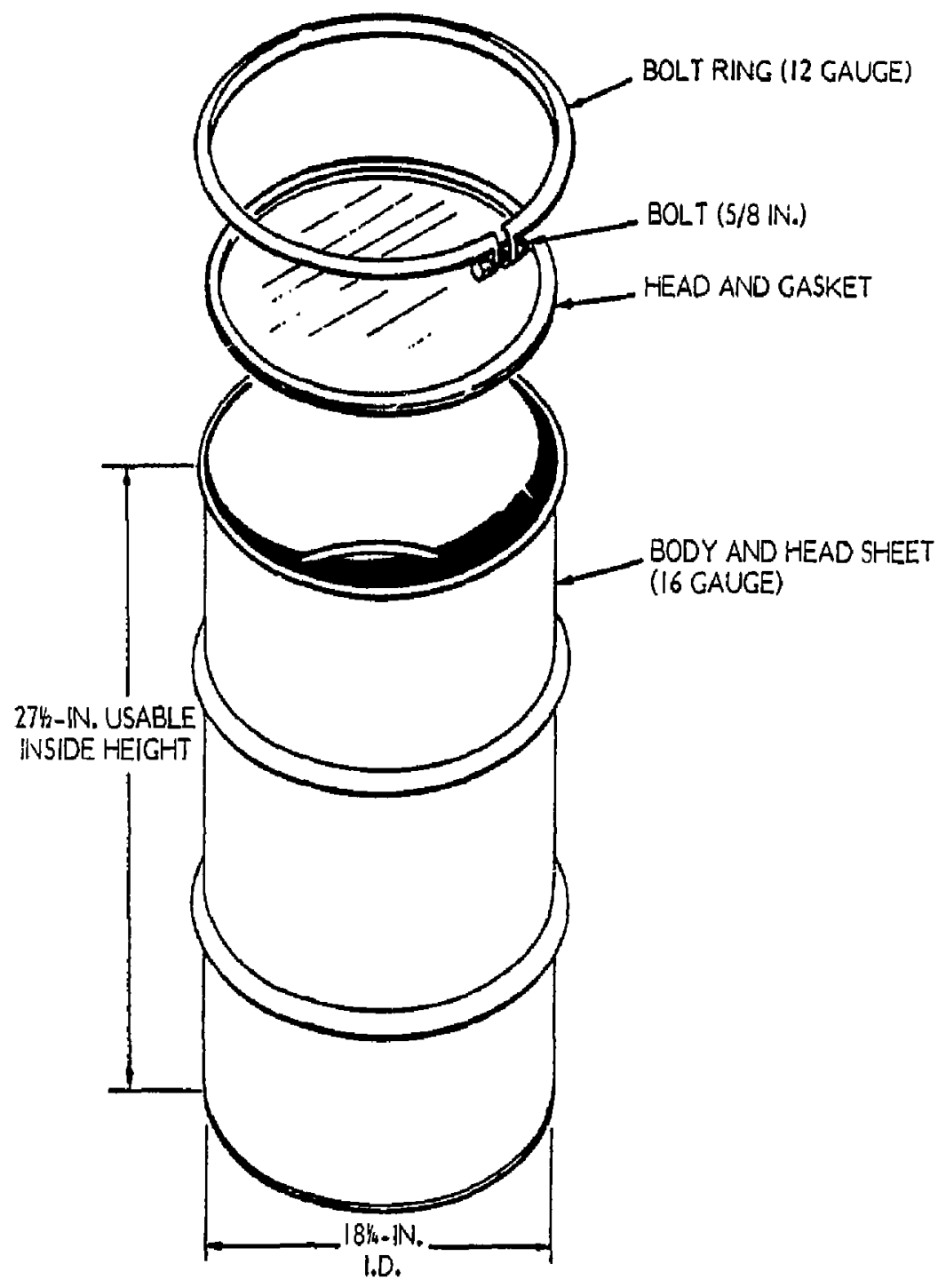

FIGURE 4-1

DOT SPECIFICATION 6B STEEL DRUM (CFR49 |78.98) 30 GALLONS (114-LITERS) 
TABLE 4-7

DOT SPECIFICATION 6C

1. COMMON NAME OF CONTAINER:

Spec. 6C Open-Head Steel Drums - 5 and 10 gollon (19-liter and 38liter)

\section{AUTHORIZED CONTENTS:}

Type "A" quantities of solid radiooctive material in normal of special form.

3. DIMENSIONS:

5 Gollon

Interior - $11 / 4 \mathrm{in.}$ i.d. $\times 123 / 4 \mathrm{in}$. inside height

Exterior - $12 y_{4}$ in. o.d. $\times 13 z_{2}$ in. overall height

10 gollon
Interior - $137 / 8 \mathrm{in.} \mathrm{i.d.} \times 16 \% \mathrm{~s}$ in. inside height
Exterior - $14.14 \mathrm{in.} 0 . \mathrm{d} . \times 18 \mathrm{in}$. overall height

4. DESCRIPTION OF CONTAINER:

5 gollons Spec 6C steel drums

22 gouge body and head sheet

20 gouge sealing ring

$7 / 32$ in. bolt

gasket required

10 gallon Spec 6C steel drums

20 gauge body and head sheet

16 gauge sealing ring

$5 / 16$ in. bolt

ga:ket required

5. SPECIFICATIONS AND RESTRICTIONS:

Authorized Gross Weight

5 gallon $-80 \mathrm{lb}(36 \mathrm{~kg})$

10 gallon - $160 \mathrm{lb}(72 \mathrm{~kg})$ 


\section{TABLE 4-7}

(CONT.)

Any bulky equipment with sharp corners, protrusions, etc., must be securely positioned within drum

Cosket material must have minimum operating range of $-40^{\circ} \mathrm{F}$ to $+130^{\circ} \mathrm{F}$.

\section{TEST RESULTS:}

\section{Environmentol Conditions}

Test

o) Heat, $+130^{\circ} \mathrm{F}$

b) Cold, $-40^{\circ} \mathrm{F}$

c) Reduced Pressure

d) Vibration

Poss
Results

Pass

Pass

Poss

\section{Discussion ond/ar Reference}

Engineering Analysis (EA) Temperature is within normal operoting range for materials of construction.

EA - Temperature is within normal operating range for materials of construction.

6C Specification requires possing 15 psig leak test - CFR49 178.99-12.

EA - Similar containers have withstood years of transport with no accurrences of significant damage due to normal vibrotion.

\section{Test Conditions}
e) Water Sproy
Not
Required
f) Free Drop (4 ft)
Poss
CFR49 173.398(b) (3) (i)
Tested with gross weights of $80 \mathrm{lb}$ and $160 \mathrm{lb}$, respectively. "Spec. 6C Open-Head Steel Drums - 5 and 10 Gallon," Technical Suppor $\bar{t}$ Document - Type A Study, MLM- 2229 (1975). 
TABLE 4-7

(CONT.)

g) Corner Drop

Not

As long as packoges are Fissile

Required Class I or exempt. CFR49 173.398 (b) (3) (iii)

h) Penetrction

Pass

"Spec 6C Open-Head Steel Drums -5 and 10 Gallon," Technical Support Document - Type A Study MLM-2229 (1975).

1) Compression

Pass

Treated with 400 and $800 \mathrm{lb}$ loads respectively. "Spec 6C OpenHead Steel Drums - 5 and 10 Gallon," Technical Support Document - Type A Study, MLM-2225 (1975). 


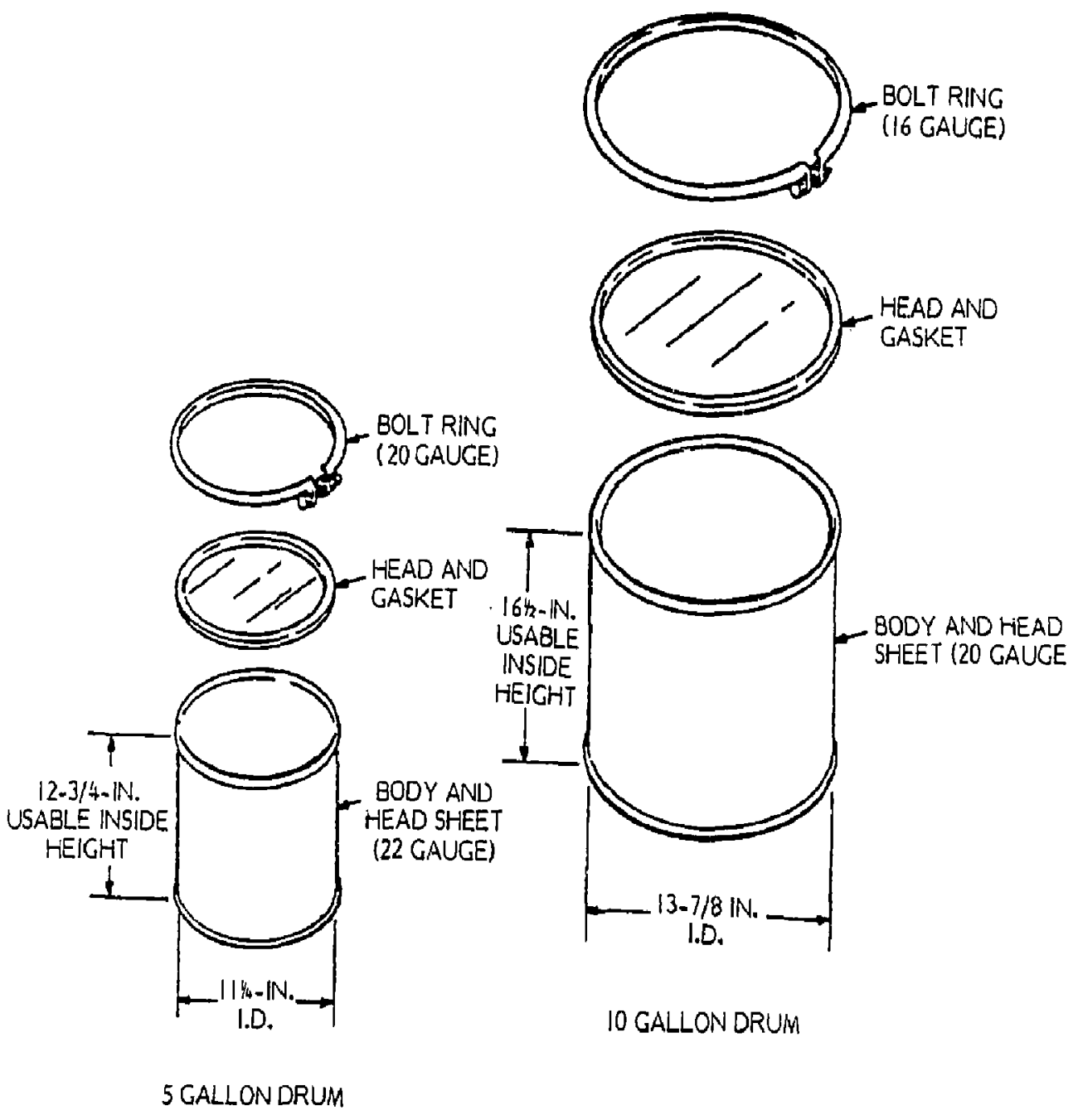

FIGURE 4-2

DOT SPECIFICATION 6C STEEL DRUMS (CFR49 178.99)

5 AND 10 GALLON (19-LITER AND 38-1TER) 
TAZLE 4-8

DOT SPECIFICATION ǴJ

1) Common Nome of Container:

Spec 6J 55-Gallon (208-Liter) Jłeel Drum

2) Authorized Contents:

Type "A" quantities of solid rodiocctive materials in normol or speciol form.

3) Dimensions:

Interior - 22k in. i.d, $\times 33$ in. usoble height

Exterior -24 in. $0.0 . \times 35$ in. outside height

4) Description of Contuiner:

55-gallon 5pec. 6J apen heod steel drum

Gosket required (see item 5)

Configuration "A" - 18 gauge head and body

- rolled or swedged in hoops

- bolt ring 14 gouge and $3 / 8$ in. bolt*

- bolt ring 12 gouge and $5 / 8 \mathrm{in.bolt*}$

Configuration "B" - 16 gouge head and body

- U-type, 14 gouge rolling hoops or 1-bor type rolling hoops (3/4 in. $x$ / $/ 4$ in.)

- sealing ring, 12 gauge and minimum of $3 / 8 \mathrm{in}$. bo!t.

5) Specifications and Restrictions:

Configuration "A" - $570 \mathrm{lb}(259 \mathrm{~kg})$ gross weight

Configurotion "B" - $880 \mathrm{lb}(440 \mathrm{~kg})$ gross weight

Any buiky equipment with shorp corners, protrusions, etc., must be securely positioned within drum.

Gasket material must have minimum operating range of $-40^{\circ} \mathrm{F}$ to $+130^{\circ} \mathrm{F}$. If sponge rubber gasket is used, a minimum diameter of $k_{2}$-in. is required.

Not outhorized for air transport unless sealed inner container capoble of meetinn reduced pressure criteria - CFR49 173.398(b) (2) (iii) is used.

\footnotetext{
Either outhorized.
} 
TABLE 4-8

(CONT.)

6) Test Results:

\section{Environmental Conditions}

Test Results Discussion and/or Reference

\section{Configuration "A"}

a) Heat, $+130^{\circ} \mathrm{F}$ Pass Engineering Analysis (EA)-Temperature is within normal operating range for materials of construction.

b) Cold, $-40^{\circ} \mathrm{F}$ Poss $5 \mathrm{~A}$ - Temperature is within normal operating range for materials of construction,

c) Reduced Not EA - Structurally, the packaging would Pressure Tested pass; however, since no air leak test is required by the DOT specification, the restriction on cir transport - item 5 was added.

d) Vibration Pass EA - Container has withstood years of transport with no occurrence of significant domage due to normal vibration.

\section{Test Conditions}
e) Woter Spray
Not
Required
f) Free Drop Poss

\section{CFR49 $173.398(b)(3)(i)$}

Tested to equivalent of $575 \mathrm{lb}$. "Supplemental Impact Tests on ICC 6-J and ICC 2-R Containers (BofE 1736), H. E. Noyes, LAMS-2983 Supplement, April 19,1965 .

g) Corner Drop Not

As long as packages are Fissile Class I or

Required exempt. CFR49 173.398 (b)(3)(iii)

h) Penetration Pass

EA - Saine gauge drums ( $17 \mathrm{H}$ ) have consistently passed this test.

i) Compression Pass EA - Similar $17 \mathrm{H}$ drum passed cornpression test with lood of $4570 \mathrm{lb}$ for $24 \mathrm{hr}$. "Spec 17H Steel Drum (55 Gallon)," Technical Support Document - Type A Study, MLM-2229 (1975). 
TABLE 4-8

(CONT.)

\section{Environmentol Conditions}

Test Results Discussion ond/or Reference

Configuration "E"

a) Heat, $+130^{\circ} \mathrm{F}$ Pass EA - Temperature is within normal operoting range for moterials of construction.

b) Cold, $-40^{\circ} \mathrm{F}$ Pass $\quad \mathrm{EA}$ - Temperature is within normal operating range for moterials of construction.

c) Reduced Not EA - Structurally, the pockoging would Pressure Tested pass; however, since no air leak test is required by the DOT specification, the restriction on oir tronsport - itern 5 . was added.

d) Vibration Pass EA - Containers hove withstood years of transport with no occurrence of significant damage due to normal vibration.

\section{Test Conditions}

e) Water Spray Not

CFR49 173.398(b)(3)(i)

Required

f) Free Drop Poss $(4 \mathrm{ft})$

CFR49 78.100-11 (o)(1) require tho Configuraition B, $6 \mathrm{~J}$ drums pass a orow test at $880 \mathrm{lb}$ - gross weight

g) Corner Drop Not

Required

As long as packages are Fissile Clajs I or exempt. CFR49 173.398(b)(3)(iii)

h) Penetrotion Poss

EA - Same gauge drums (17C) have : onsistently passed this test. "Spec 6 B Steel Drum (30 Gallon)," Technical Support Document - Type A Study, iviLM-222 (1975).

i) Compression Pass

EA - 17H drum with smaller gouge wolls and head sheet passed compression test with lood of $4570 \mathrm{lb}$. "Spec 17H Stee! Drum (55 Gallon)," Technical Support Document - Type A Study, MiLM-2229 (19ा5). 


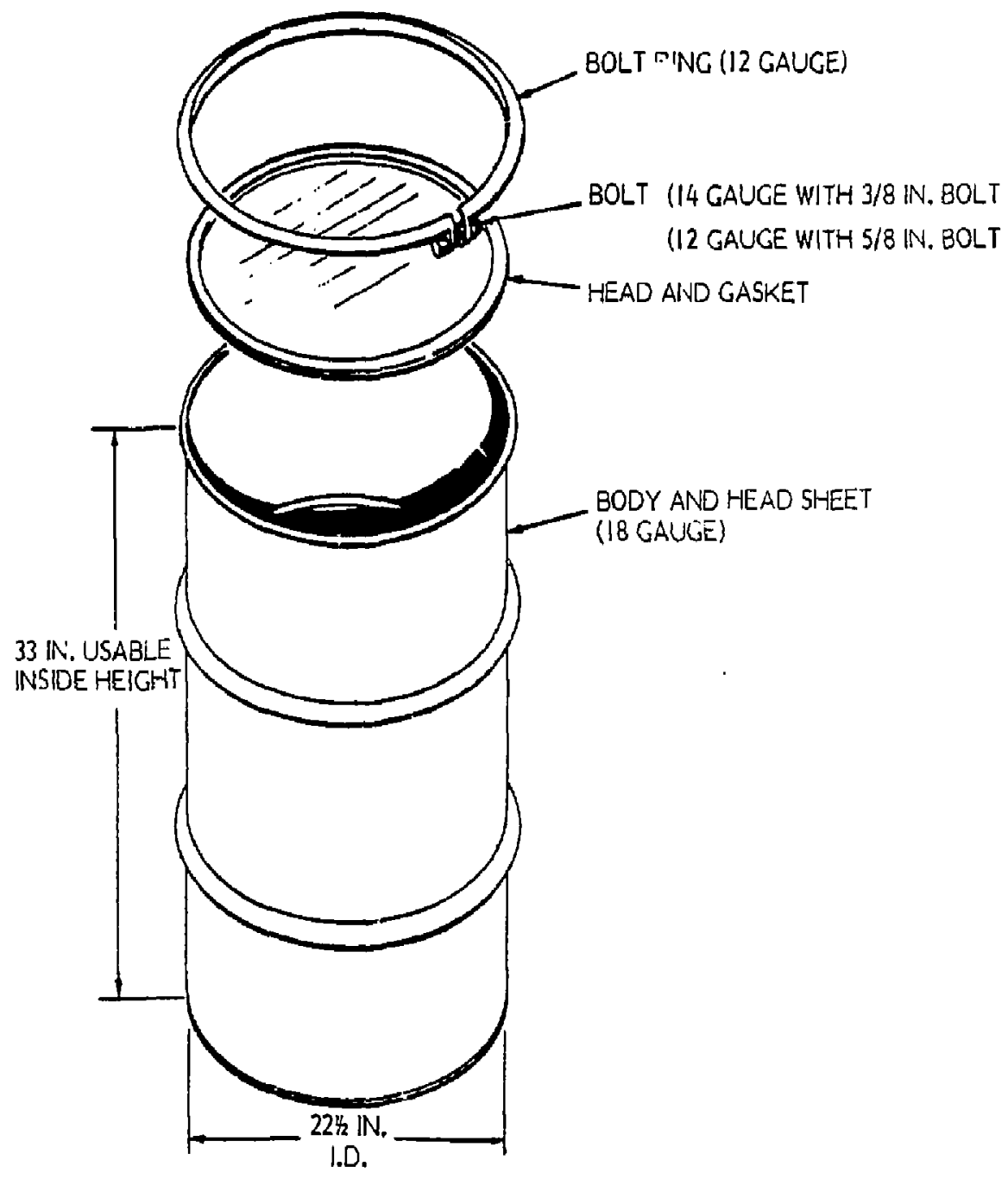

CONFIGURATION "A"

FIGURE 43

DOT SPECIFICATION 6J STEEL DRUM (CFR 49 178.100)

55 GALLON (208LITER) 


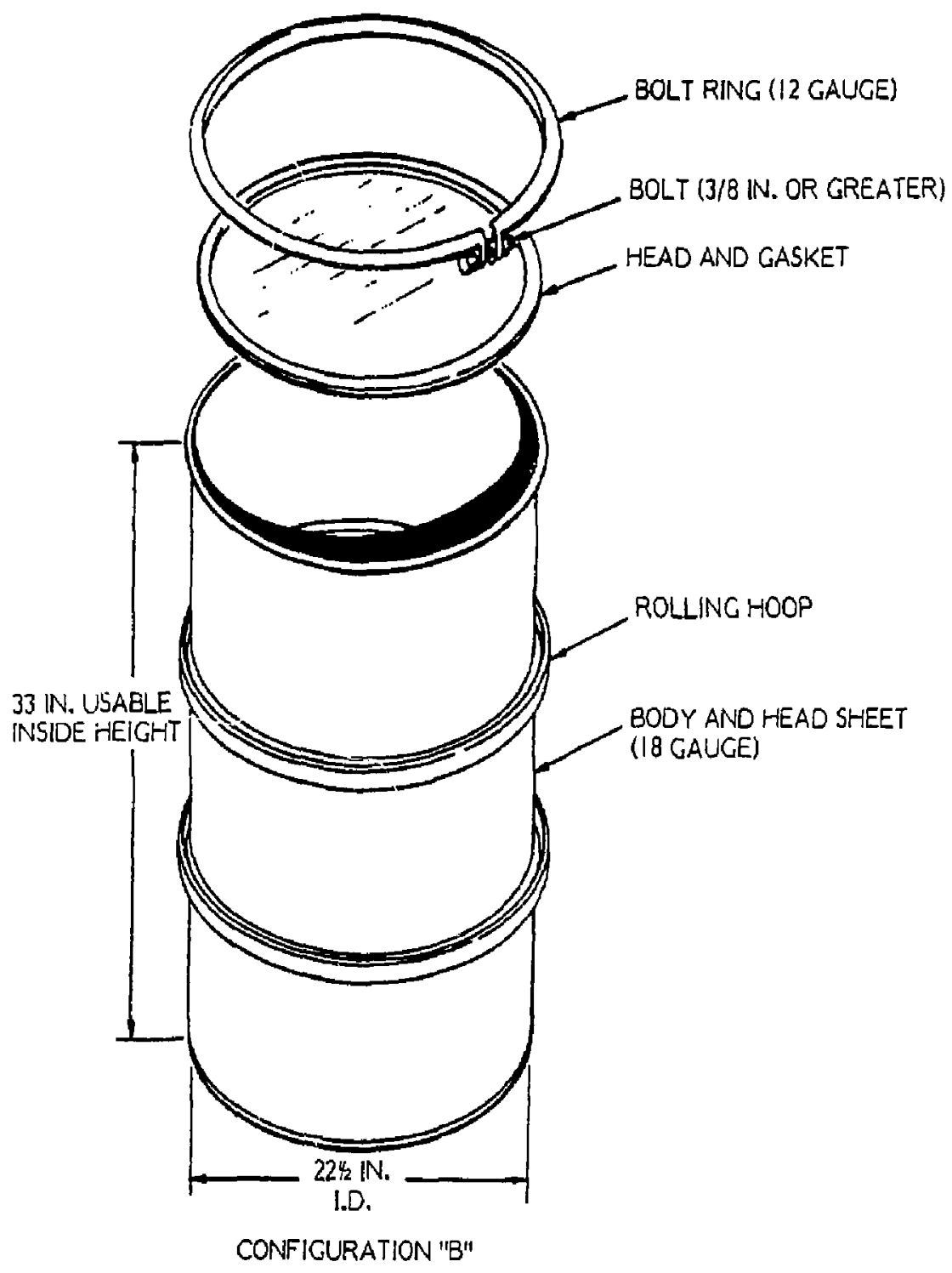

FIGURE 4-4

DOT SPECIFICATION 6J STEEL DRUM (CFR 49 178.100) 55 GALLON (208-LITER) 
TABLE 4-9

DOT SPECIFICATION GL

i) Common Nome of Container:

Spec ól

2) Authorized Contents:

Type "A" quantities of radioactive materials in normal or special form.

3) Dimensions:

$2 R$ Inner Contoiner when outer container is 5.5 -gallon (208-liter) drum 5.25 in. i.d. $x 26$ in. moximum length

$2 R$ Inner Container when outer container is 110 -gollon $(416$-liter) drum 5.25 in. i.d. $x 50$ in. maximum length

4) Qescription of Contoiner:

Inner steel container with luted thread, Spec. 2R (CFR49 178.34) held within outer shell of 18 gouge minimum body and bottom headsheets and 14 or 16 (see CFR49 178.103-3(0)) gauge removable head sheets.

Void space filled with bogged or tamped vermiculite.

Closure - 12 gouge bolt ring with minimum of $5 / 8$ in. diometer steel bolt.

- Minimum diameter of $22.5 \mathrm{in}$. required for outer container.

Inner container fixed in ploce by one of methods given in HM- $1 \mid$, 178.103-3c(1), (2) or (3). Loose, untomped vermiculite not outhorized - H-M-111 173.103-3(j).

5) Specificotions and Restrictions:

Rodioactive moterials which will not decompose of temperatures up to $750^{\circ} \mathrm{F}$.

Authorized Gross Weight - 55 gallon - $350 \mathrm{lb}(159 \mathrm{~kg})$

110 gallon $-480 \mathrm{lb}(218 \mathrm{~kg})$ 
TABLE 4-9

(CONT.)

6) Test Results:

\section{Environmental Conditions}

Test Results Discussion and/or Reference

d) Heat, $+130^{\circ} \mathrm{F}$ Pass Docket No. HiM-111, published 12-31-74

b) Cold, $-40^{\circ} \mathrm{F}$ Poss Docket No. FiMi-III, published $|2-3|-74$

c) Reduced Pass Docket No. HiM-111, published 12-31-74 pressure

d) Vibrotion Pass Docket No. HM-111, published 12-31-74

Test Conditions

e) Woter sprcy Pass Docket No. HM-111, published 12-31-74

f) Free drop Pass Docket No. HM-1I1, published 12-31-74 $(4 \mathrm{ft})$

g) Corner drop Pass Docket No. HM- III, published 12-31-74

h) Penetration Poss Docket No. HM- |l|, published |2-3|-74

i) Compression Pass Docket No. HM- |1 I, putlished I2-3!-74 


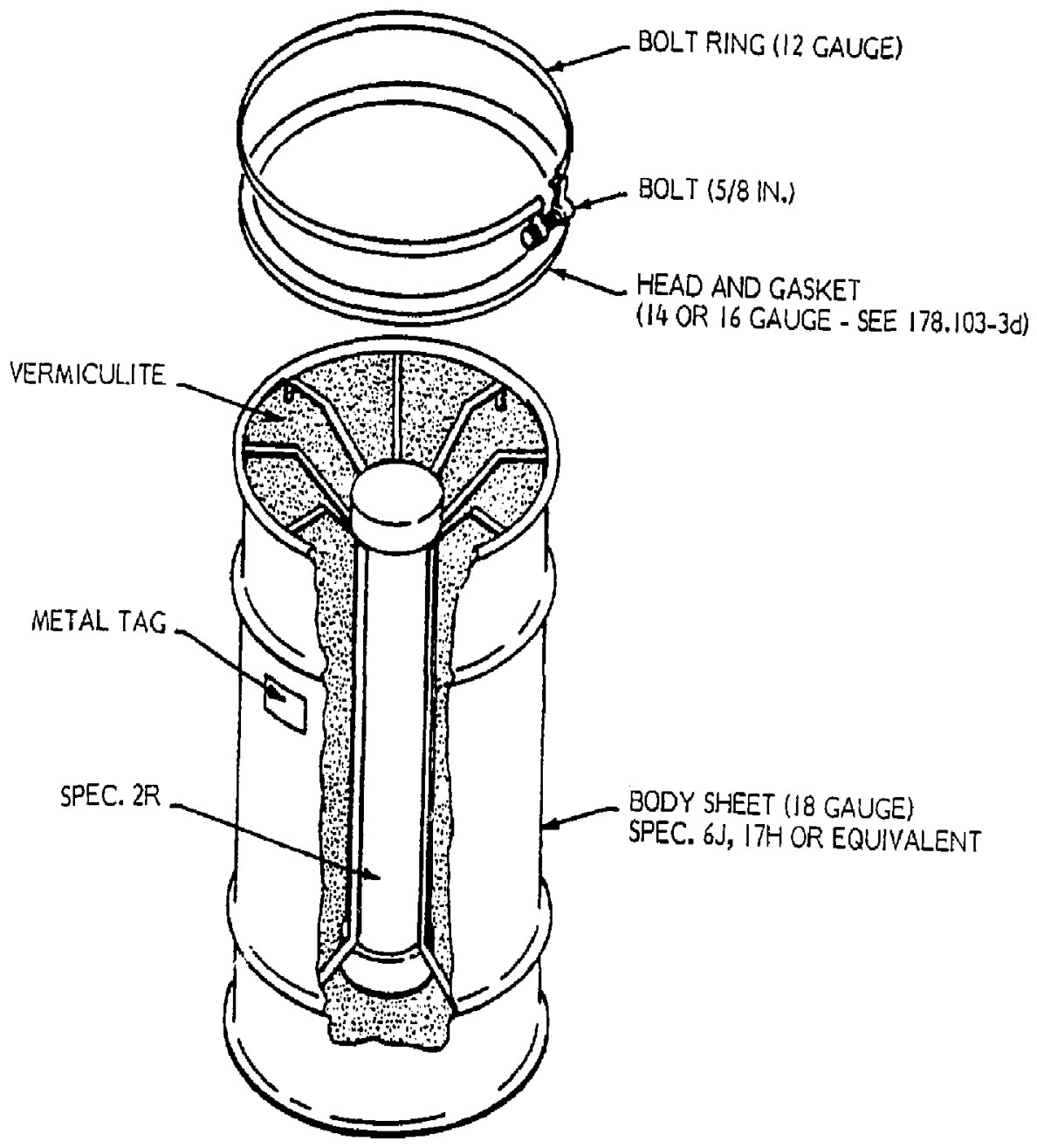

FIGURE $4-5$

DOT SPECIFICATION 6L (CFR49 |78.103) 


\section{TABLE 4-10}

\section{DOT SPECIFICATION GM}

1) Common Name of Container:

Spec $6 \mathrm{in}$

2) Authorized Contents:

Type A quantities of solid radioactive materials in normal or special form.

3) Dimensions:

Inner Contoiner - Maximum 5 in. o.d.

Duter Container - Depends on size of outer drum chosen - minimum of 10 gallon, maximum of 110 gallon container.

4) Description of Container:

5pec. $6 \mathrm{C}$ or $17 \mathrm{C}$ steel drum or equivalent havifig fiberboard, etc. [CFR49 178.104-3c(1) or (2)] insulation, centering o Spec 2R (CFR49 178.34) container

5) Specifications and Restrictions:

Authorized only for solid radjoactive materiols which do not decompose of temperatures up to $250^{\circ} \mathrm{F}$.

\begin{tabular}{|c|c|c|c|c|c|}
\hline Marked Capacity & \multicolumn{2}{|c|}{$\begin{array}{c}\text { Maximum } \\
\text { Authorized } \\
\text { Gross } \\
\text { Weight }\end{array}$} & \multirow[t]{2}{*}{$\begin{array}{l}\text { Minimum } \\
\text { Thickness } \\
\text { of Uncooted } \\
\text { Sheets } \\
\text { and Heod } \\
\text { (gauge) }\end{array}$} & \multicolumn{2}{|c|}{$\begin{array}{l}\text { Minimum } \\
\text { Thickness } \\
\text { of End } \\
\text { Insulotion }\end{array}$} \\
\hline (gal) (Jiters) & (lb) & $(k y)$ & & (in.) & $6 \mathrm{~cm}$ \\
\hline $\begin{array}{r}57 \\
114 \\
210 \\
420\end{array}$ & $\begin{array}{l}160 \\
480 \\
640 \\
640\end{array}$ & $\begin{array}{r}73 \\
219 \\
292 \\
292\end{array}$ & $\begin{array}{l}20 \\
18 \\
16 \\
16\end{array}$ & $\begin{array}{l}1.88 \\
3.75 \\
3.75 \\
3.75\end{array}$ & $\begin{array}{l}4.7 \\
9.5 \\
9.5 \\
9.5\end{array}$ \\
\hline
\end{tabular}




\section{TABLE 4-10}

(CONT.)

6) Test Results:

\section{Environmental Conditions}

Test Results Discussion and/or Reference

a) Heat, $+130^{\circ} \mathrm{F}$ Pass Docket No. HM-111, published 12-31-74

b) Coid, $-40^{\circ} \mathrm{F}$ Poss Docket No. Him-111, published 12-31-74

c) Reduced Dacket No. HM-111, published |2-j|-74 Pressure

d) Vibrotion Pass Docket No. HM-111, published 12-31-74

\section{Test Conditions}

e) Water sproy Pass Docket No. HM-111, published 12-31-74

f) Free drop Pass Docket No. HM-111, published 12-31-74 $(4 \mathrm{ft})$

g) Corner drop Pass Docket No. HM-1I!, published |2-31-i4

h) Penetration Poss Docket No. Hin-11!, published 12.31-74

i) Compression Pass Oocket No. Hiv-111, published 12-31-74 


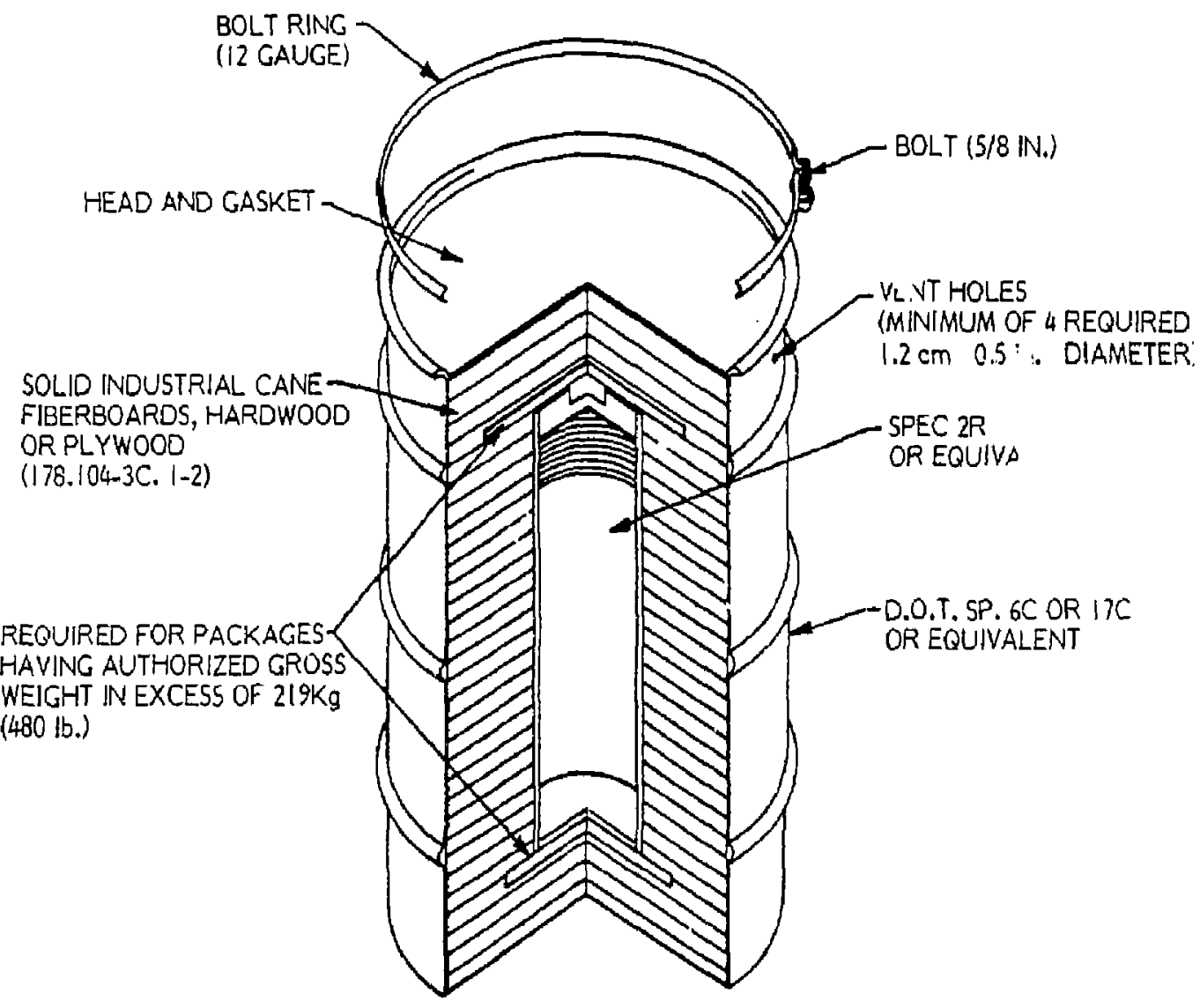

FIGURE 4-6

DOT SPECIFICATION GM

(CFR49 178.104) 


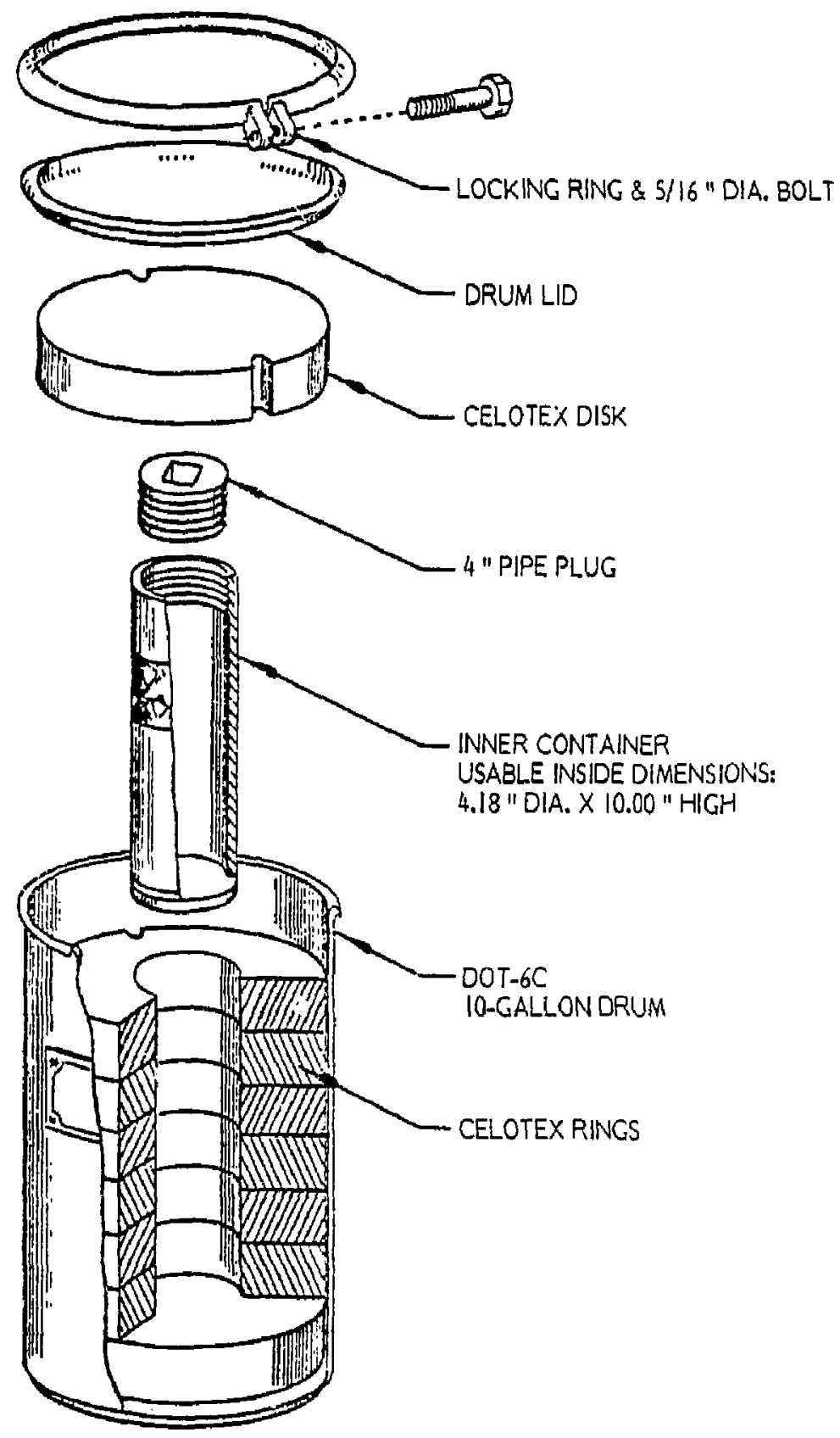

FIGURE 47

DOT SPECIFICATION 6M

ROCKY FLATS MODEL 1518 


\section{REQUIREMENTS FOR DOT-7A PACKAGES}

1. Title 49 Code of Federol Reguiation Requirements:

- 178.350 Specification 7A; general packaging, Type A.

- 178.350-1 General requirements. (o) Each packoging must meet all applicable requirements of pora. 173.24 .

- 178.350-2 Specific requirements. (o) Each packaging must be so designed and constructed thot it meets the stondards for Type A pockaging (see parc. 173.389(j) and 173.398(b)).

- 178.350-3 Morking. (o) Morking on the outside of each packaging as follows: "USA DOT-7A Type A" and "Radioactive Material." (b) Marking to conform with paro. 173.24.

2. Directly or by reference, DOT-7A pockaging rnust comply with the following Title 49 CFR paragrophs:

173.24 Standard Requirements for All Pockages

173.389(j) Type A Packaging

173.393 General Pockaging and Shipping Requirements

173.395(o)(1) Rodicactive Materiol in Normol Form Specification 7A

173.398(b) Standards for Type A Pockaging 
1) Common Name of Container:

Arganne National Laboratory's Steel Bin (M- III Bin)

2) Authorized Contents:

Type A quantities of solid rodioactive moterials in normal or special form.

3) Dimensions:

Interior - Width - 58 ina, height - 72 in., length - 50 in.

Exterior - Width-58 $3 / 8$ in., height $-723 / 8$ in., length $-503 / 8$ in.

4. Description of Container:

Bin constructed of 12 gauge low carbon steel with continuous bead welds at all bin wall joints

Volume - $121 \mathrm{ft}^{3}\left(3.4 \mathrm{~m}^{3}\right)$

Closure consists of 12 gauge cover, bloted to bin flanges by eight bolts, with weother stripping or equivalent gasket moteriol.

2 lifting devices.

5) Specifications and Restrictions:

- Authorized Net Weight - $2500 \mathrm{lb}$ (1136 kg)

- Authorized Gross Weight - $3200 \mathrm{lb}(1454 \mathrm{~kg})$

- Shielding - 0.1 in. (2.54 mm) steel

- Not to exceed Fissile Closs 1

- Not authorized for air transport - See item 6(C)

6) Test Results:

\section{Environmental Conditions}

Test

o) Heat, $+130^{\circ} \mathrm{F}$

Pass

b) Cold, $-40^{\circ} \mathrm{F}$

Poss

c) Reduced Pressure

Not

Tested

\section{Discussion and/or Reference}

Engineering Analysis (EA) - Temperature is within normal operating range for materials of construction.

EA - Temperature is within normal operaving range for moterials of construction.

This test wos not conducted; hence, the restriction from air transport. 
TABLE 4-12

(CONT.)
Test Results Discussion and/or Reference
d) Vibrotion
Pass
Containers have withstood years of tronsport with no occurrence of signifi- cont domage due to normal vibration.

\section{Test Conditions}

e) Water Sproy

Not

CFR49 173.398 (b) (3) (i)

Required

f) Free Drop (4 ft.) Poss

Letter - W. H. Kline to B. Devine dated 12-26-67. "ANL's Steel Bin," Technical Support Document - Type A Study, MLM-2229, (1975).

g) Corner Drop

Not

Required

As long as packnge is Fissile Closs I or exempt. CFR49 173.398 (b) (3) (iii).

h) Penetration

Poss

Letter - W. H. Kline to B. Devine dated 12-26-67. "ANL's Steel Bin," Technical Support Document - Type A Study, MLM-2229, (1975).

i) Compression

Pass

Letter - W. H. Kline to B. Devine dated 12-26-67. "ANL's Steel Bin," Technical Support Document - Type A Study, MLM-2229, (1975). 


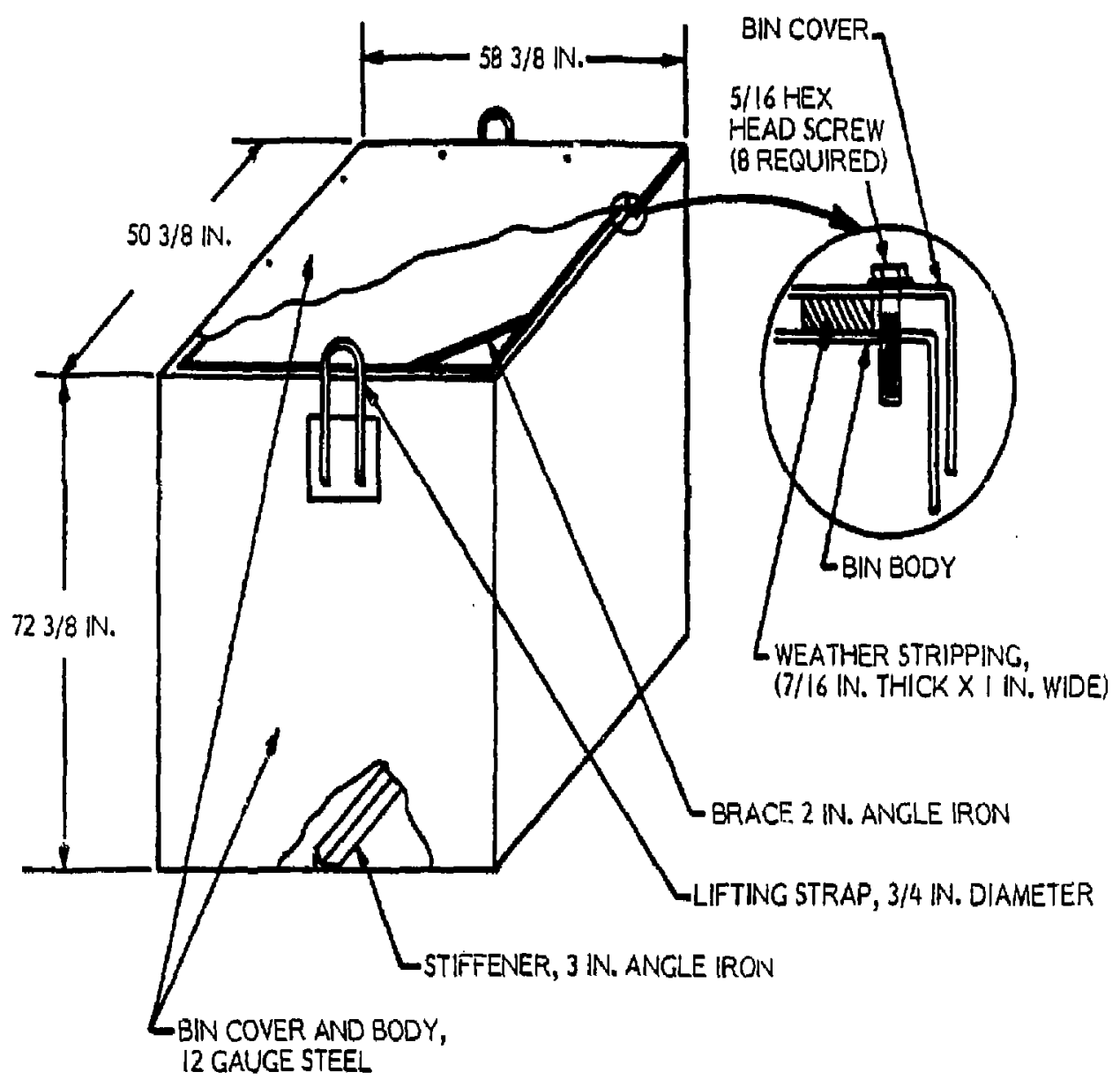

FIGURE 4-8

DOT SPECIFICATION 7A STEEL BOX

(CFR49 178.350) 
TABLE $4-13$

\section{DOT SPECIFICATION TA STEEL BIN}

1) Common Name of Container:

BCL-5 Shipping Container

2) Authorized Contents:

Type "A" quantities of solid radioactive material in nermal or special form. Rodionctive material to be prepackaged in strong urums, wooden boxes, or equivalent containment.

3) Dimensions:

Interior - Width - 60 in., length - 120 in., height -72 in.

Exterior - Width - 72 in., length - 132 in., height - 78 in.

4. Description of Container:

Constructed of $1 / 4 \mathrm{in}$. mild steel plote with continuous welded seams and reinforced with tubing and channel. Closure is provided by 28 each $3 / 4$ in. Hex Head Boits. Lid rests on continuous band of $1 / 4$ in. $x$ 2 in. neoprene gasket material. Container serves as, outer packages and is reusable. The internal volume is $300 \mathrm{ft}^{3}\left(8.5 \mathrm{~m}^{3} \%\right.$.

5) Specifications and Restrictions:

- Authorized Net Weight - $6000 \mathrm{lb}(2727 \mathrm{~kg})$

- Authorized Gross Weight - 13,000 lb (5909 kg)

- All joints sealed against water in-leakage

- Shielding - 1/4 in. $(6.35 \mathrm{~mm})$ steel walls

- Lifting and Tie-down devices - see referenced drowings

- Single stacking only authorized because compression test or engineering onalysis not conducted

- Not to exceed Fissile Class 1

- Not authorized for air transport - see item $6(C)$

6) Test Results:

\section{Environmental Conditions}

\section{Test}

d) Heat, $+130^{\circ} \mathrm{F}$

b) Cold, $-40^{\circ} \mathrm{F}$

Poss

\section{Discussion and/or Reference}

Engineering Anclysis (EA) - Temperature is within normal operating range for materials of construction.

EA - Temperature is within normal operating range for materials of construction. 
TABLE $4-13$

(CONT.)
Test Results Discussion and/or Reference
c) Reduced Pressure Not Not tested bosed on use considerations, Tested hence, the restriction on oir tronsport.
d) Vibration Pass
EA - Container hos withstood years of transport with no occurrence of signifi- cant damage due to normal vibration.

\section{Test Conditions}
e) Water Sproy
Not
CFR49 173.398 (b) (3) (i)
Required
f) Free Drop (4 ft.) Poss
"BCL-5 Shipping Container," Tectnical Support Document. Type A Study,

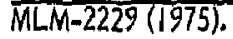

g) Corner Drop

Not

Required

As long as pockage is Fissile Class / or exempt. CFR49 173.398 (b) (3) (iii).

h) Penetrotion

Pass

"BCL-5 Shipping Container," Technical Support Document - Type A Study, MLM2229 (1975).

i) Compression Not

Not tested, hence stacking not Tested authorized. 
TABLE 4-14

DOT SPECIFICATION 7A STEEL BOX

1) Common Name of Container:

Type A Steel Box

2) Authorized Contents:

Type "A" quantities of solid rodiooctive material in normal or speciol form.

3) Dimensions:

Interior - Width - $34 \mathrm{in.}$, length - $72.5 \mathrm{in}$, height - 48 in.

Exterior - Width -34.5 in., length -73 in., height -48.5 in.

\section{Description of Container:}

Steel box constructed of 1/4 in. steel plate (cold rolled steel or equivalent) with all segams, including finol closure, welded. Volume of box tested was $68 \mathrm{ft}^{3}\left(1.9 \mathrm{~m}^{3}\right)$. Two $3 / 4$ in, eye-bolts are welded in place for lifting and o vent pipe is installed in the top with threads for a cap or plug. Four inch casters were welded to each corner; however, this is optional.

5) Specificotions and Restrictions:

- Authorized Maximum Net Weight - $4000 \mathrm{lb}(1818 \mathrm{~kg})$

- Authorized Gross Weight - $5000 \mathrm{lb}(2272 \mathrm{~kg})$

- Shielding - $1 / 4$ in. $(6.35 \mathrm{~mm})$ steel

- Vent pipe must be left open during final sealing weld to allow for escope of heoted air inside and sealed after final welding completed.

- Not authorized for oir shipments.

- Stacking not authorized.

6) Test Results:

\section{Environmental Conditions}

Test

Results

Discussion and/or Reference

a) Heat, $+130^{\circ} \mathrm{F}$ Pass

Engineering Analysis (EA) - Temperature is within normal operating range for materials of construction.

b) Cold, $-40^{\circ} \mathrm{F}$ Pass $\mathrm{EA}$ - Temperature is within normal operating range for materials of construction. 



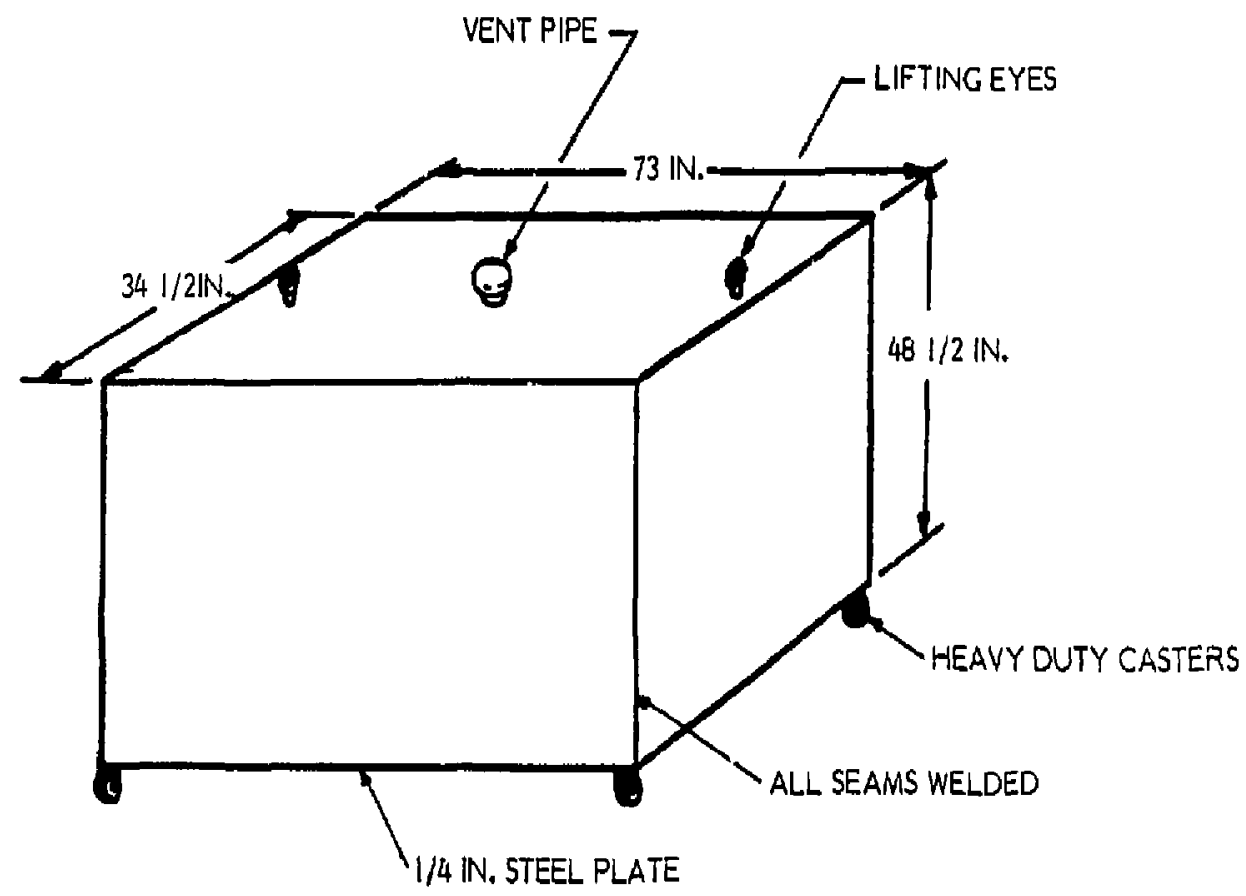

FIGURE $4-10$

DOT SPECIFICATION 7A STEEL BOX

(CFR49 178.350) 



\section{TABLE 4-15}

(CONT.)

\section{Configurotion $B$}

Authorized Gross Weight - 20,000 lb $(9090 \mathrm{~kg})$

Shielding - 17 in of concrete

Fissile Class - Not to exceed Fissile Class I

6) Iest Results:

\section{Environmental Conditions}

Test

Rosults

Discussion ond/or Reference

a) Heat, $+130^{\circ} \mathrm{F}$

Poss

Engineering Anolysis (EA) - Temperature is within normal operating ronge for materials of construction.

b) Cold, $-40^{\circ} \mathrm{F}$

Poss

EA - Temperature is within normal operating range for moteriols of construction.

c) Reduced Pressure

Not

Not evoluated; hence pockage restricted

Tested from air tronsport.

d) Vibration

Pass

Container has withstiood years of tronsport with no occurrence of significant damage due to normal vibration.

\section{Test Conditions}

e) Woter Spray

Not

Required

f) Free Drop (4 ft.) Pass

CFR49 173.398 (b) (3) (i)

Internal Letter (Brookhoven National Laboratory), F. Edward to P. Colsmann dated May 14, 1974. "Concrete Voult," Technicci Support Document Type A Study, MLM-2229 (1975).

g) Corner Drop Not

Required

As long os packoge is Fissile Class I or exempt. CFR49 173.398 (b) (3) (iii).

h) Penetration Pass

EA - Packoging would easily poss the penetration test.

i) Compression Not

Not tested since cover lid is actually sloped to provide water drainage, thus precluding stacking (Not shown on drawirigs). 


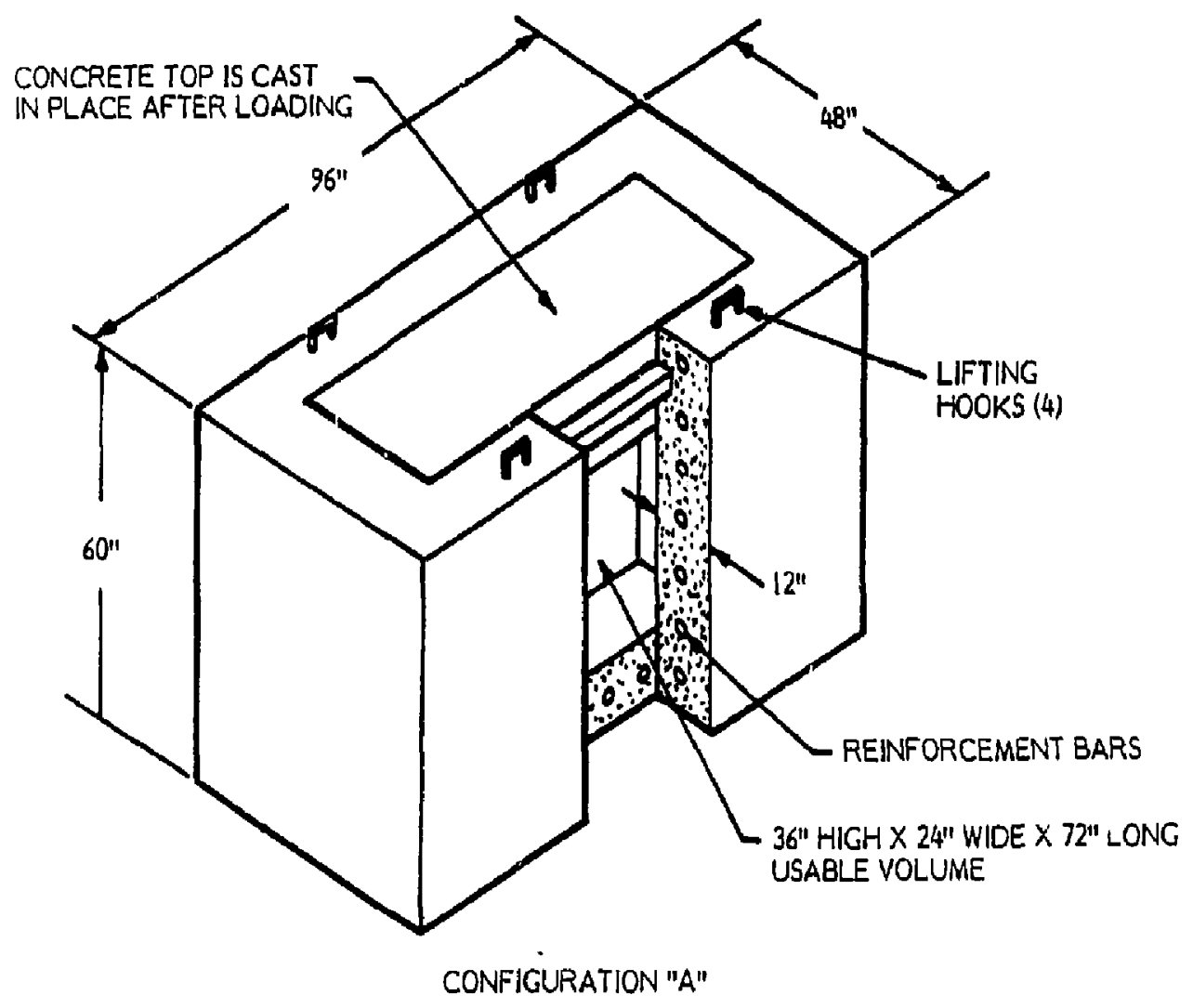

FIGURE $4-11$

DOT SPECIFICATION 7A CONCRETE VAULT

(CFR49 |78.350) 


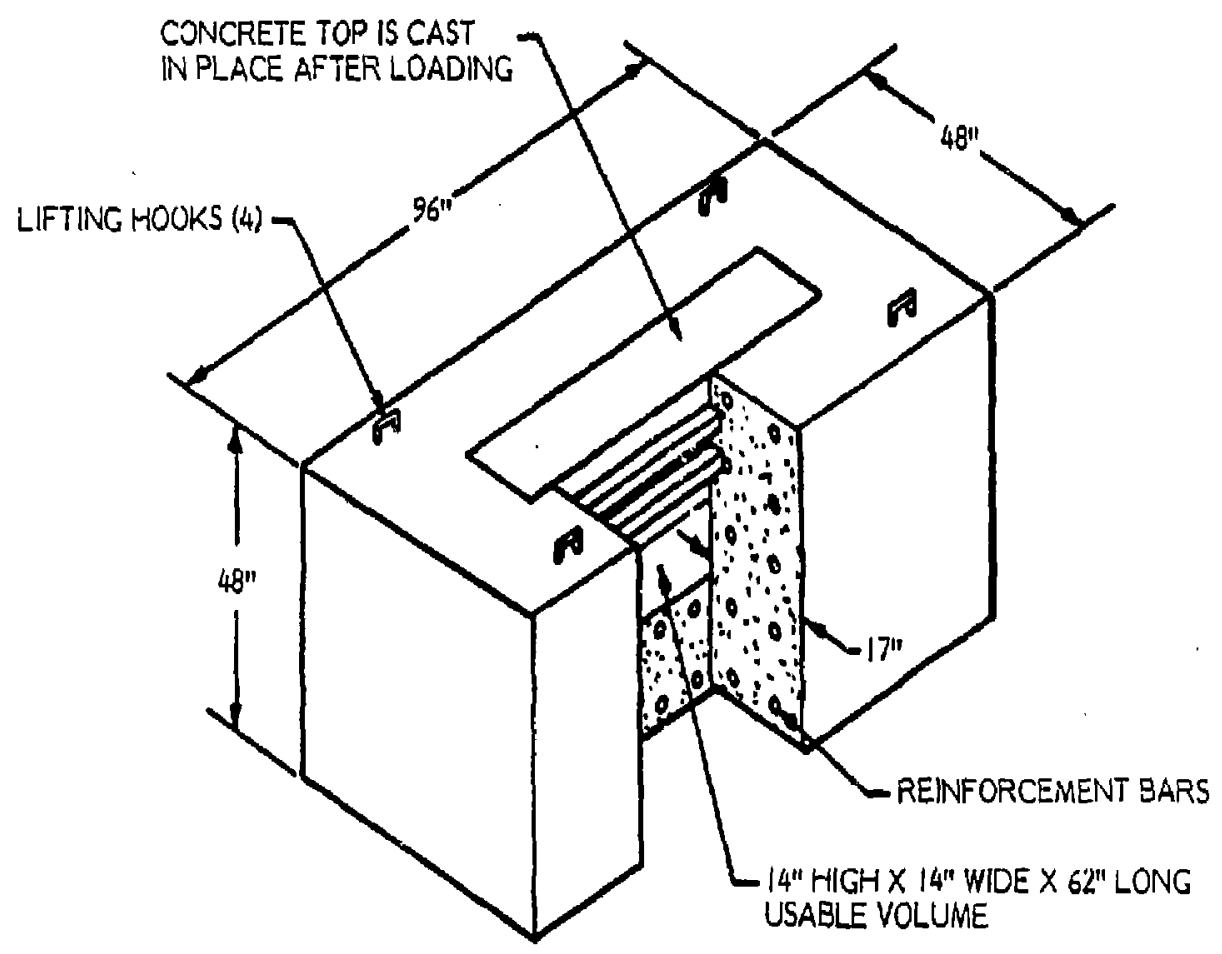

CONFIGURATION "B"

FIGURE $4-12$

DOT SPECIFICATION TA CONCRETE VAULT

(CFR49 (78.350) 


\section{TABLE 4-16}

DOT SPECIFICATION 7A STEEL DRUM

1) Common Name of Container:

Follansbee Drum = MS 24347-2

2) Authorized Contents:

Type "A" quantities of solid radioactive moterial in normal of special form.

3) Dimensions:

Interior - 5 in. i,d, $\times 8 \mid / 2$ in. usable inside height

Exterior -6 in. o.d. $\times 9$ in, overall outside height

4. Description of Container:

0.7 gallon (approximaiely) steel drum - MS $24347-2$

16 gouge top, bottom and sides

Gosket

5) Specifications ond Restrictions:

- Authurized Gross Weight - $25 \mathrm{lb}(\mathrm{ll} \mathrm{kg})$

- Any bulky equipment with sharp corners, protrusions, etc., must be securely positioned within drum.

- Gasket material must have minimum operating range of $-40^{\circ} \mathrm{F}$ to $+130^{\circ} \mathrm{F}$.

6) Test Results:

\section{Environmental Conditions}

Test

a) Heat, $+130^{\circ} \mathrm{F}$

Pass

b) Cold, $-40^{\circ} \mathrm{F}$

Pass

c) Reduced Fressure Pass

\section{Discussion and/or Reference}

Engineering Anolysis (EA) - Temperature is within normal operating range for materials of construction.

EA - Temperature is within normal operating range for moterials of construction.

Tested. "Follansbee Drum - MS 24347. 2," Technical Support Document - Type A Study, MLM-2229 (1975). 


\section{TABLE 4-16}

(CONT.)
Test Results Discussion and or Reference
d) Vibration
Pass
Containers have withstood years of transport with no occurrences of signifi- cont damoge due to normal vibrotion.

\section{Test Conditions}
e) Water Sproy
Not
CFR49 173.398 (b) (3) (i)
Required
f) Free Drop (4 ft.) Poss
Tested with gross weight of $25 \mathrm{lb}$ "Fol- lansbee Drum - MS 24347-2," Technical Support Document - Type A Study, MLM-2229 (1975).

g) Corner Drop

Not

Required

As long as packoge is Fissile Class I or exempt. CFR49 173.398 (b) (3) (iii).

h) Penetrotion

Peiss

Tested. "Follonsbee Drum -MS 24347-2," Technical Support Document - Type A Study, MLM-2229 (197.).

i) Compression

Foss

Tested with gross weight of 200 lb locd. "Follansbee Drum - MS 24347-2," Technical Support Document - Type A Study, MLM-2229 (1975). 


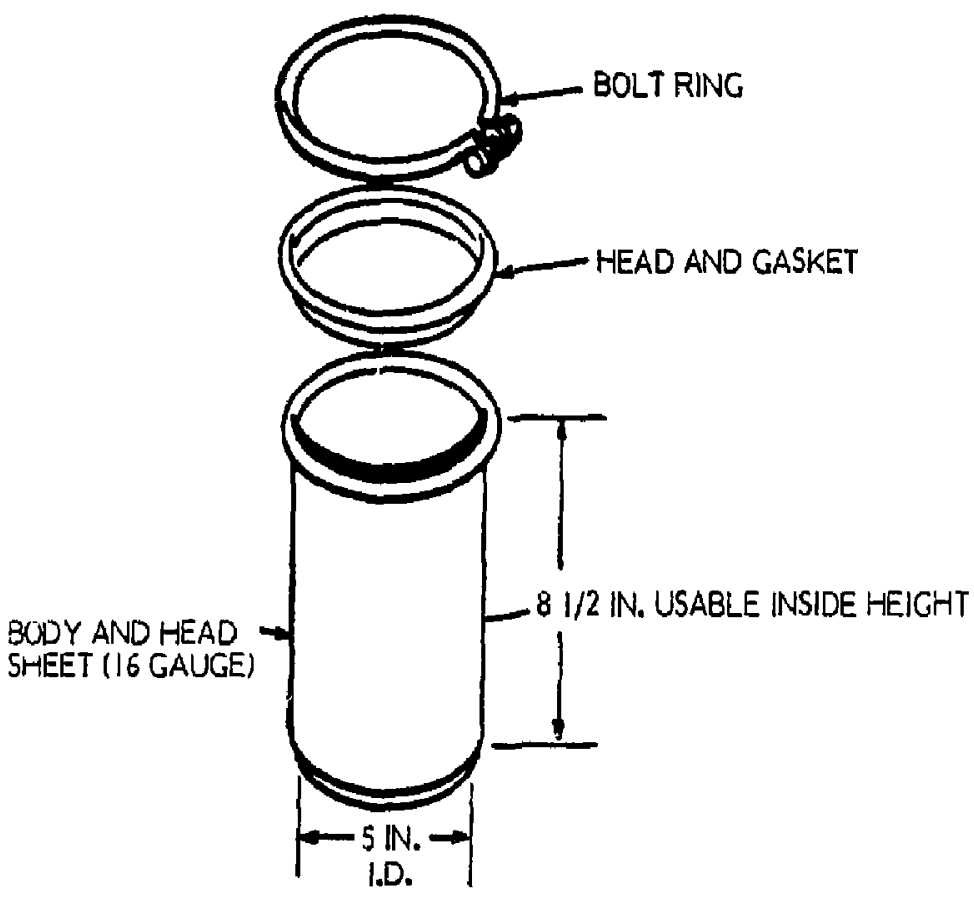

FIGURE 4-13

DOT SPECIFICATION TA STEEL DRUM

(CFR49 (78.350) 
1) Common Nome of Contoiner:

4 Gallon Steel Drum - MS 27684-2

2) Authorized Contents:

Type "A" quantities of solid rodiactive material in normal or special form.

3) Dimensions:

Interior - 10 1/2 in. i.d. $\times 13$ //2 in. usable inside height

Exterior - 12 in. 0.d. $\times 143 / 4$ in, overall outside height

4. Description of Container:

4 gallon steal drum (1.1 L), MS 27684-2

20 gouge top, bottom and side

Gasket (see iter 5)

5) Specifications and Restrictions:

- Authorized Gross Weight - $69 \mathrm{lb}(31 \mathrm{~kg})$

- Any bulky equipment with sharp corners, protrusions, etc., must be securely positioned within drum.

- Gosket material must hove minimum operating ronge of $-40^{\circ} \mathrm{F}$ to $+130^{\circ} \mathrm{F}$.

6) Test Results:

\section{Environmental Conditions}

Test Results Discussion and'... Reference

a) Heut, $+130^{\circ} \mathrm{F}$ Pass Engineering Analysis (EA) - Temperoture is within normal operating range for materials of construction.

b) Cold $-40^{\circ} \mathrm{F}$ Pass EA - Temperoture is within normal operating ronge for materials of construction.

c) Reduced Pressure Pass " "4 Gallon Steel Drum - MS 27684-2," Technical Support Document - Type A Study, MLM-2229 (1975).

d) Vibrotion Poss Containers have withstood years of transport with no occurrences of significant damage due to normal vibration. 
TABLE 4-17

(CONT.)

\section{Test Conditions}

\begin{tabular}{|c|c|c|c|}
\hline & Test & Results & Discussion and/or Reference \\
\hline e) & Water Spray & $\begin{array}{l}\text { Not } \\
\text { Required }\end{array}$ & CFR49 173.398 (b) (3) (i) \\
\hline f) & Free Drop (4 ft.) & Pass & $\begin{array}{l}\text { Tested with gross weight of } 69 \mathrm{lb} \text {. "4 } \\
\text { Gallon Steel Drum - MS } 27684-2 \text { ", } \\
\text { Technical Support Docunent -Type A } \\
\text { Study, MLM-2229 (1975). }\end{array}$ \\
\hline g) & Corner Drop & $\begin{array}{l}\text { Not } \\
\text { Required }\end{array}$ & $\begin{array}{l}\text { As long as package is Fissile Class I or } \\
\text { exempt. CFR49 173.398 (b) (3) (iii). }\end{array}$ \\
\hline h) & Penetration & Pass & $\begin{array}{l}\text { "4 Gallon Steel Drum - MS 27684-2," } \\
\text { Technical Support Document - Type A } \\
\text { Study, MLM-2229 (1975). }\end{array}$ \\
\hline i) & Compression & Puss & $\begin{array}{l}\text { Tested with } 400 \text { lb loord. "4 Gallon Steel } \\
\text { Drum - MS } 27684-2, " \text { Tcchnical Support } \\
\text { Document - Type A Study, MLM-2229 } \\
\text { (1975). }\end{array}$ \\
\hline
\end{tabular}




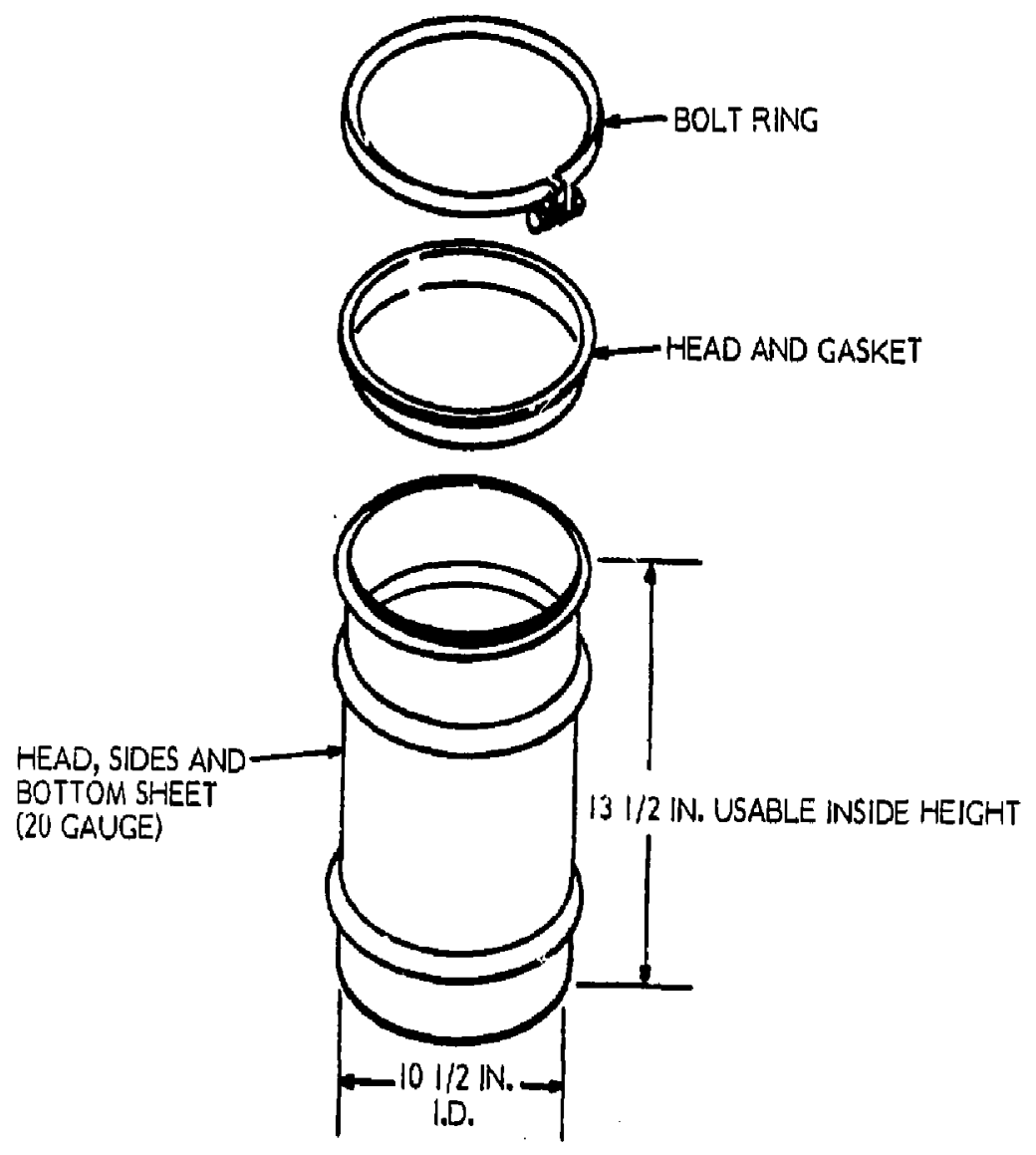

FIGURE 4-14

DOT SPECIFICATION 7A STEEL DRUM

(CFR49 178.350) - 4 gallon (I.IL) 


\section{TABLE 4-18}

\section{LOT SPECIFICATION 7A SHIPPING CONTAINER}

1) Common Name of Container:

ORNL's Spec 7A Contoiner

2) Authorized Contents:

Type A quantities of liquid and solid radioactive materials in normal $\alpha$ special form.

3) Dimensiori:

Interior Cavity (for placement of Spec 6D steel pack) -

$123 / 4$ in. i.d. $x 151 / 8$ in. high

Exterior (dimension of $17 \mathrm{H}$ - 55 gollon steel drum) 22 //2 in. 0.d. $\times 35$ in. high

4. Description of Container:

The packoge is a 55 gallon (208-L) drum (DOT Spec. 17H) lined with Foomglas insulation. The inner cavity is capable of accepting o 5-gal polyethylene drum (5pec 25) with screw cap closure contained in a 24 gouge steel pail (Spec 6D).

5) Specifications and Restrictions:

- Authorized Gross Weight - $120 \mathrm{lb}(54 \mathrm{~kg})$

- Gasket material must have minimum operating range of $-40^{\circ} \mathrm{F}$ to $+130^{\circ} \mathrm{F}$.

6) Test Results:

\section{Environmental Conditions}

$\begin{array}{lll}\text { Test } & \text { Results } & \text { Discussion and/or Refererice } \\ \text { a) Heat, }+130^{\circ} \mathrm{F} & \text { Poss } & 1\end{array}$

* This packoge was given the $30 \mathrm{ft}$ drop test and no liquid was released from the primary container (25 polyethylene drum) and the DOT Spec $17 \mathrm{H} 55-$ Gallon Steel Drum meets the requirements of $\mathrm{HM}-11 \mathrm{I}, 173.393(\mathrm{~g})(3)$.

\footnotetext{
DOT Specification of a container designed for use by Chemical Technology
} Division, ORNL-TM-2731 (Nov. 1969) Drawing No. M-121-66-CD-038-D. 


\section{TABLE 4-18}

(CONT.)
Test
Results Discussion and/ar Reference
b) Cold, $-40^{\circ} \mathrm{F}$
Pass
c) Reduced Pressure
Pass
d) Vibrotion
Puss

Test Conditions
e) Water Spray
Not
CFR49 173.398 (b) (3) (i)
Required
f) Free Drop (4 ft.) Pass
g) Corner Drop
Not
As long as package is Fissile Class 1 or Required exempt. CFR49 173.39B (b) (3) (iii).
h) Penetration
Pass
i) Compression
Pass

DOT Specification of a container designed for use by Chemical Technology Division, ORNL-TM-273! (Nov. 1969) Drawing No. M-121-66-CD-038-D. 


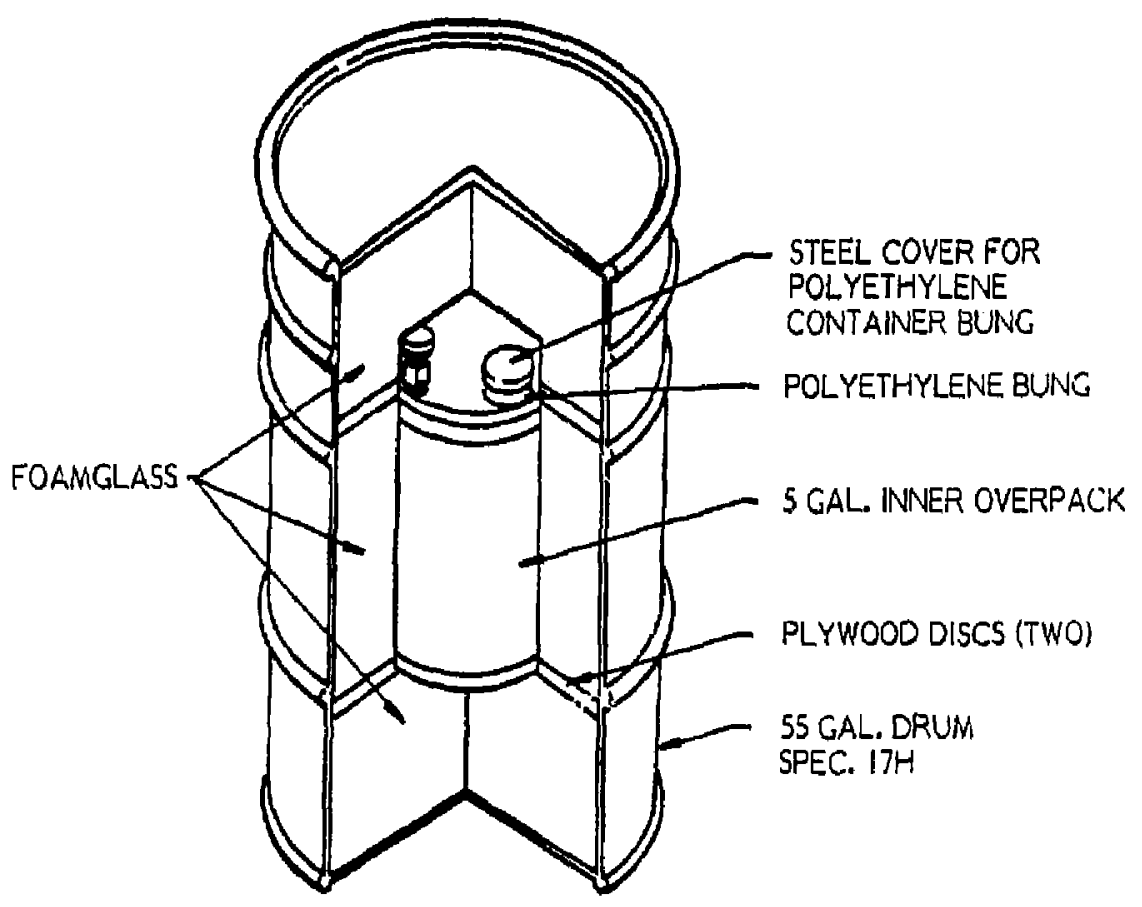

FIGURE 4-15

DOT SPECIFICATION 7A SHIPPING CONTAINER

(CFR49 178.350)

4-51

TERACORPORATION 
TABLE 4-19

\section{DOT SPECIFICATION TA \\ STEEL-BANDED WOODEN SHIPPINO CONTAINER}

1) Common Name of Container:

Spec 7A Steel-Banded Wooden Shipping Container

2) Authorized Contents:

Type "A" quantities of various depleted, normal and enriched uronium in quantities ranging from $10 \mathrm{ing}$ to spproximotely $1600 \mathrm{lb}$ net weights.

3) Dimensions:

See Drowings.

4. Description of Container:

A family of steel banded woaden shipping curritainers is described in detail in "Sofety Analysis Report for Packaging Steel Banded Wooden Shipping Containers for Slightly Enriched Uranium Metal," D. L. Dunoway, NLCO-1107 Cater̨ory: UC-71, July 1974.

5) Specifications and Restrictions:

- Stacking is not outhorized.

- See NLCO-1107 for other specifications and restrictions.

6) Test Results:

\section{Environmental Conditions}

\begin{tabular}{lll}
\multicolumn{1}{c}{ Test } & Results & Discussion and/0: Fieference \\
a) Heat, $+130^{\circ} \mathrm{F}$ & Pass & 1 \\
b) Cold, $-40^{\circ} \mathrm{F}$ & Pass & 1 \\
c) Reduced Pressure & Pass & 1 \\
d) Vibration & Poss & 1
\end{tabular}

\section{Test Conditions}

e) Water Sproy

Poss

f) Free Drop (4 ft.) Pass

"Safety Analysis Report for Pockaging Steel Banded Wooden Shipping Contoiner for Slightly Enriched Uronium Metal," D. L. Dunoway, NLCO-1107 Category: UC-71, July 1974. 


\section{TABLE 4-19 \\ (CONT.)}
Test Results Discussion ond/or Reference
g) Corner Drop
Pass
Letter: D L. Dunaway to C. E. Block dated $3 / 27 / 75$. Technical Support
Document - Type A Study, MLM-2229 (1975).
h) Penetration
Results
Need
Qualification
i) Compression
Not
Evaluoted
Hence, the restriction on stacking (see item 5) 


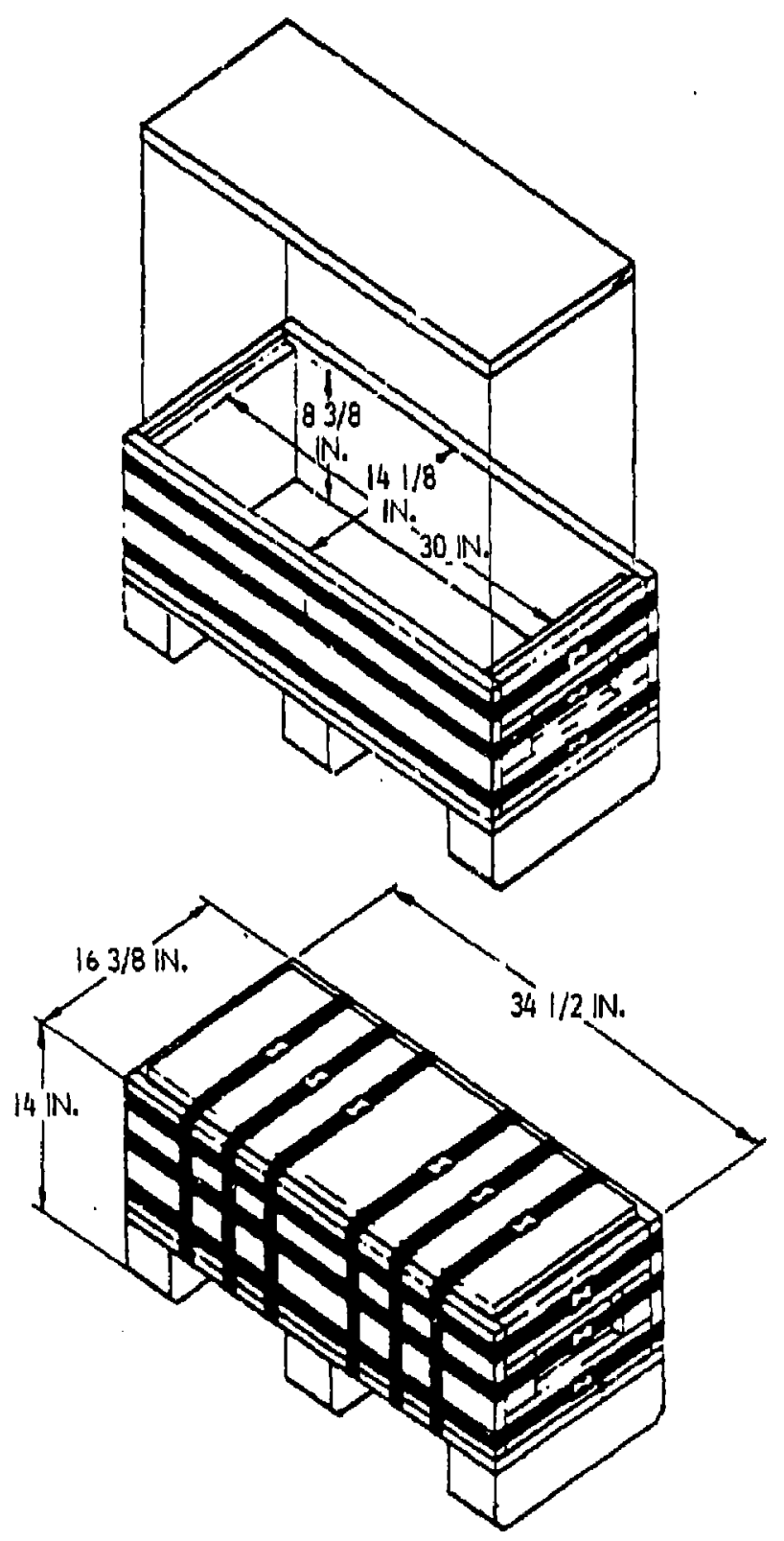

FIGURE $4-16$

DOT SPECIFICATION 7A STEEL-BANDED

WOODEN SHIPPING CONTAINER

N.L.O. MODEL G-4214 


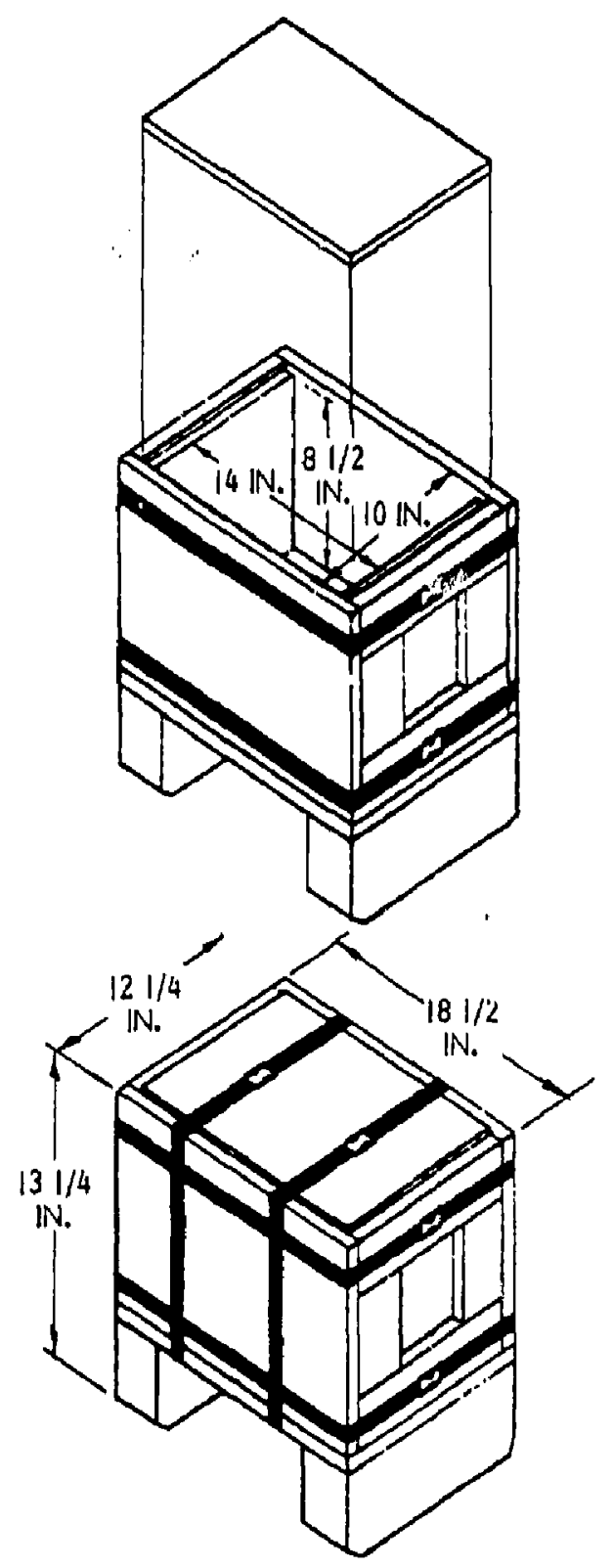

I

I

FIGURE 4-17

DOT SPECIFICATION 7A STEEL-BANDED WOODEN SHIPPING CONTAINER

$$
\text { N.L.O. MODEL G-4245 }
$$



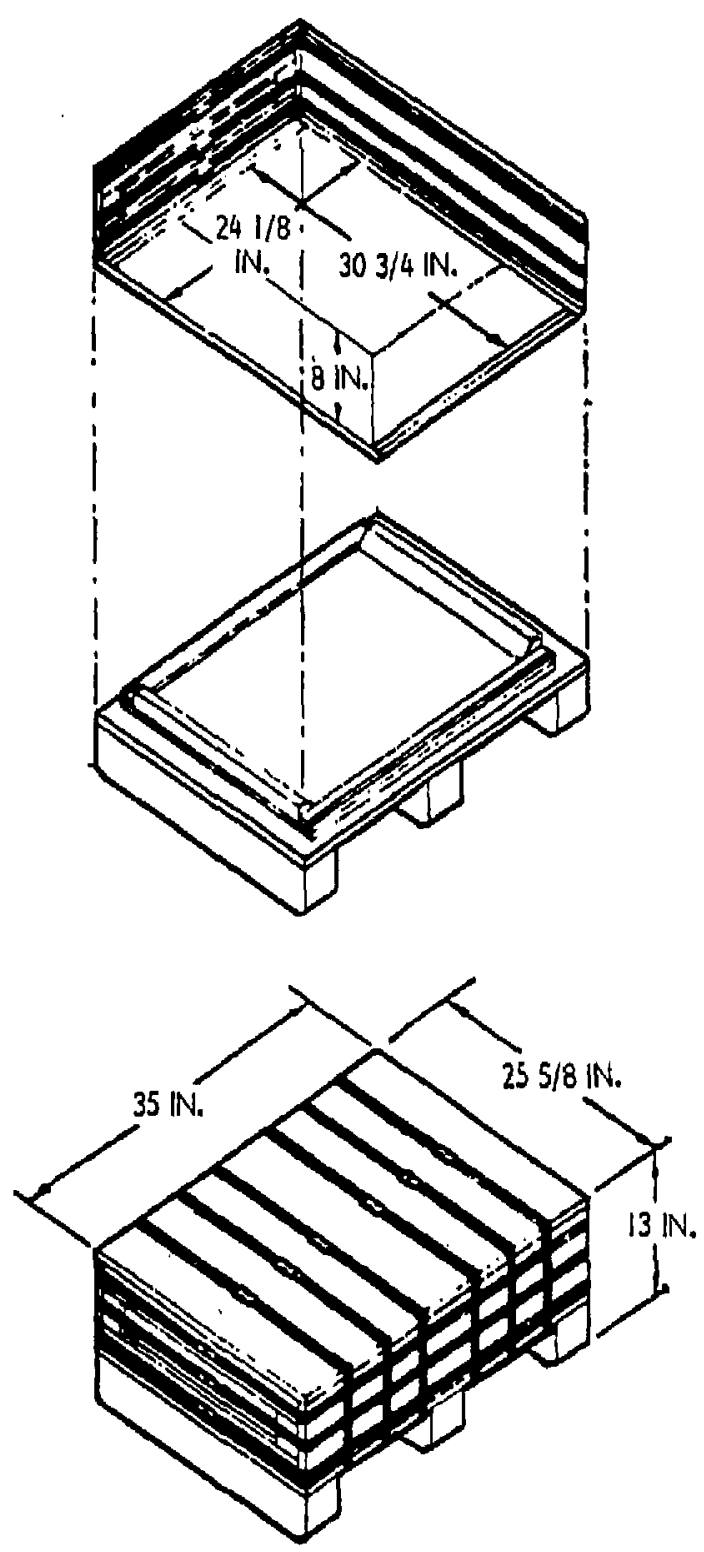

FICURE 4-18

DOT SPECIFICATION 7A STEEL-BANDED WOODEN SHIPPING CONTAINER N.L.O. MODEL G-4255 


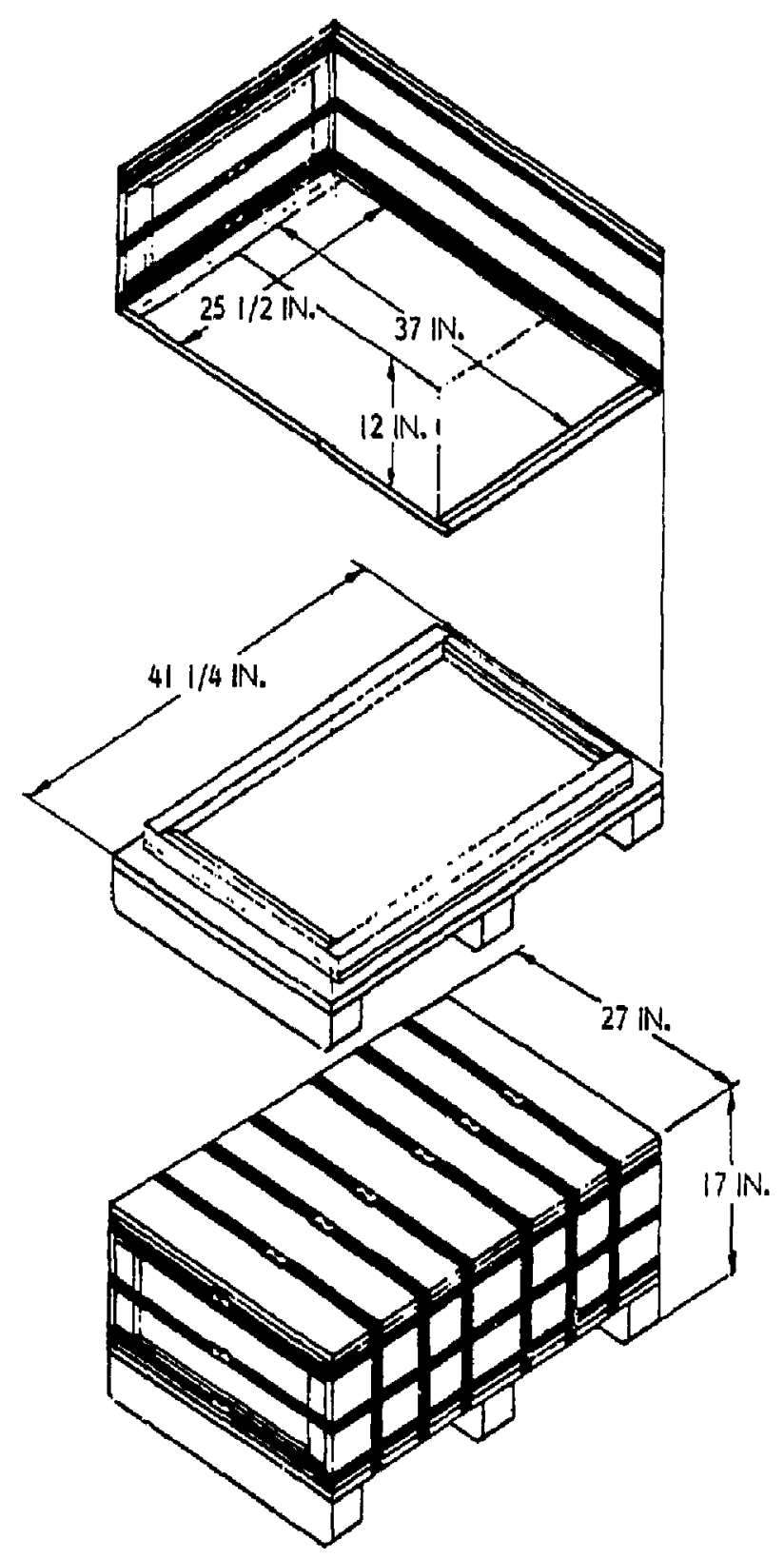

FIGURE 4-19

DOT SPECIFICATION 7A STEEL-BANDED WOODEN SHIPPING CONTAINER N.L.O. MODEL G-4273 


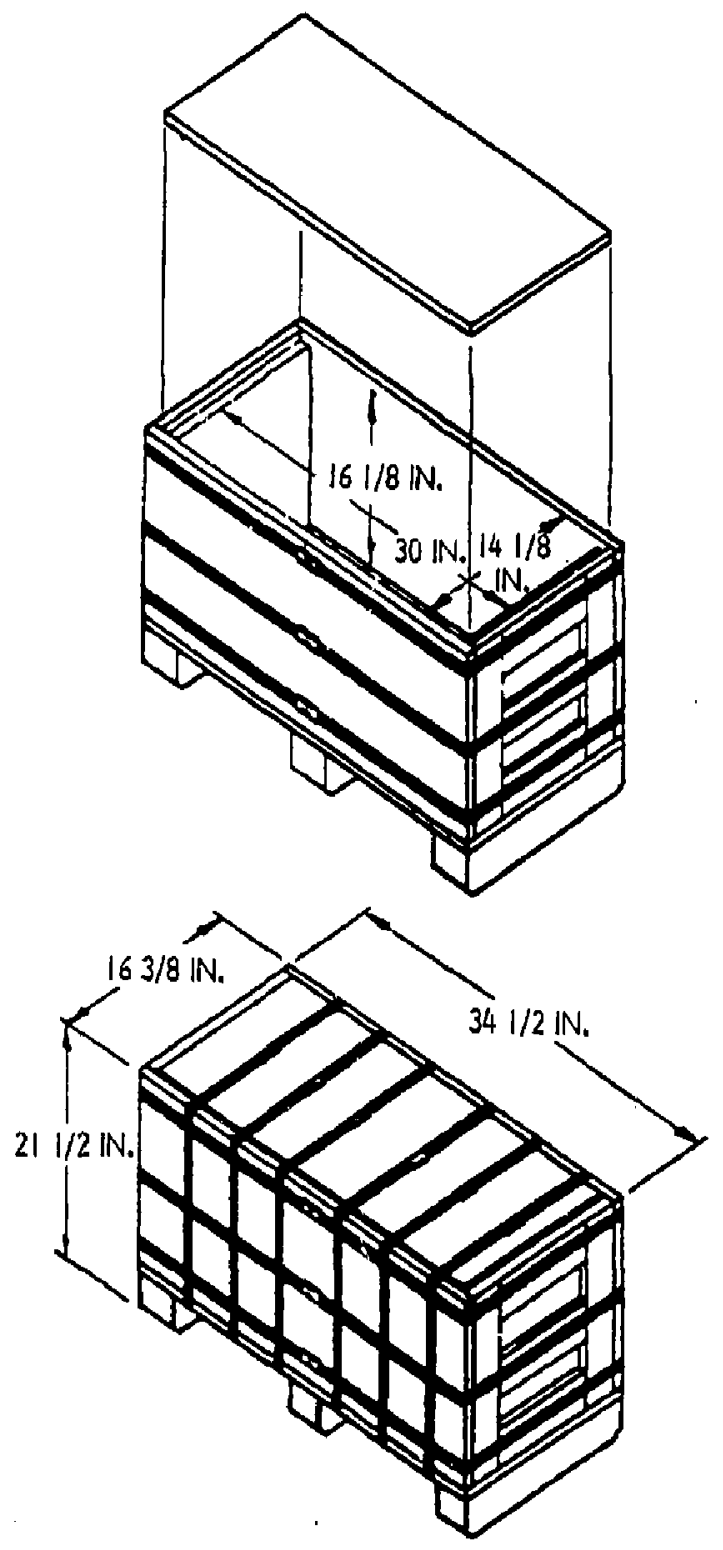

FIGURE $4-20$

DOT SPECIFICATION 7A STEEL-BANDED

WOODEN SHIPPING CONTAINER

N.L.O. MODEL G-4292 


\title{
TABLE 4-20
}

DOT SPECIFICATION 7A (FIBERGLASS-COATED PLYWOOD BOX)

\author{
1) COMMON NAME OF CONTANER \\ Rocky Flats DOT-7A box \\ 2) DIMENSIONS \\ See drowings following
}

3) MATERIALS OF CONSTRUCTION

The following materials ore specified for construction:

Plywood - Exterior type, unsanded, grade C-C or better, 3/4-inch thick.

Framing Members - 2- by 4-inch 545 (sanded four sides), seasoned, select to be free of bark and loose knots.

Adhesive - White, woter-fesistant resin give

Fasteners - Cement-cooted box noils ( 16 penny, 10 penny and 6 penny)

Resin - Flame-resistant polyester resin

Fiberglass - Continuous strand roving chopped in 2-inch lengths during spray-up opplication. 


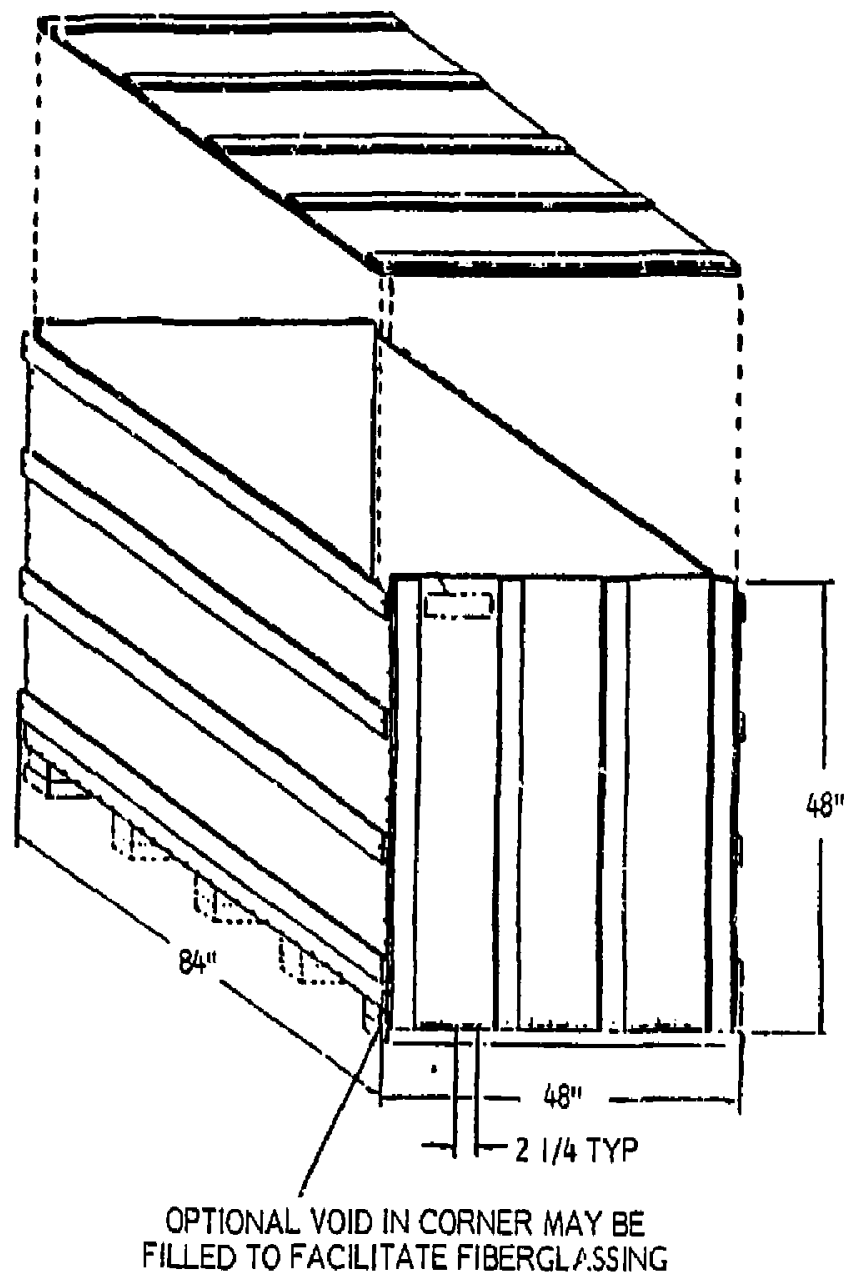

FIGURE 4-21

DOT 7A CLEATED PLYWOOD BOX ASSEMBLY 


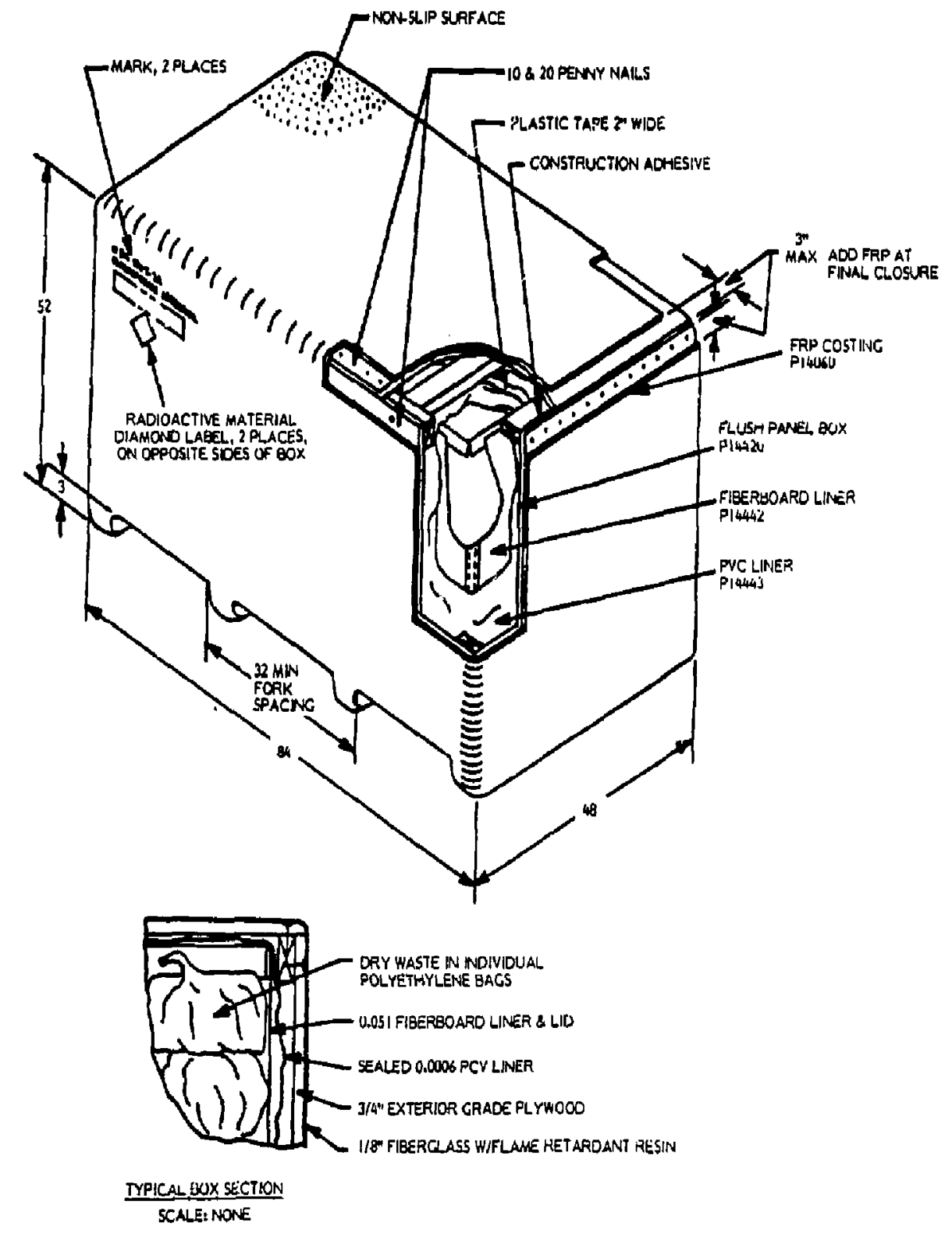

FIGURE 4-22

DOT-7A FIBERGLASS-COATED PLYWOOD BOX 
TABLE 4-21

DOT SPECIFICATION 17C STEEL DRUM

1) Common Name of Contoiner:

Spec I7C 5-Gallon (1.3 L) Poil

2) Authorized Contents:

Type "A" quantities of solid radioactive materiol in normal or special form.

3) Dimensions:

Interior - $11-1 / 4$ in. i.d. $\times 12-1 / 2$ in. usable height

Exterior - 12 in. o.d. $x 13$ in, outside height

4. Description of Container:

Spec 17C, 5-gallon steel pail

Body, top and bottom sheet - 24 gauge

Bolt ring - 18 gouge

Bolt - $1 / 4$ in.

Gasket required

5) Specifications and Restrictions:

- Authorized Gross Weight - $100 \mathrm{lb}(45 \mathrm{~kg})$

- Any bulky equipment with sharp corners, protrusions, etc., must be securely positioned within drum.

- Gosket material must have minimum operating range of $-40^{\circ} \mathrm{F}$ to $+130^{\circ} \mathrm{F}$.

6) Test Results:

Environmental Conditions

Test Results Discussion and/or Reference

a) Heot, $+130^{\circ} \mathrm{F} \quad$ Poss Engineering Analysis (EA) - Tempernture is within normal operating range for materials of construction.

b) Cold, $-40^{\circ} \mathrm{F}$ Pass - Temperoture is within normal operating range for materials of construction.

c) Reduced Pressure Pass $17 \mathrm{C}$ Specification requires passing 15 psig leak test - CFR49 178,115-13. 


\section{TABLE 4-21}

(CONT.)
Test
Results
Discussion and/or Reference
d) Vibration
Pass
Containers have withstood years of transport with no occurrences of signifi- cant damage due to normal vibration.

\section{Test Conditions}
e) Water Sproy
Not
CFR49 173.398 (b) (3) (i)
Required
f) Free Drop (4 ft.) Pass
"Spec 17C 5-Callon Pail," Technical Support Document - Type A Study, MLM-2229 (1975).

g) Corner Drop

Not

As long as package is Fissile Class I or

Required exempt. CFR49 173.398 (b) (3) (iii).

h) Penetration

Pass

"Spec 17C 5-Gallon Pail," Iechnical Support Document - Type A Study, MLM2229 (1975).

i) Compression Pass

Tested with load of $500 \mathrm{lb}$ applied for 24 hr. "Spec 17C 5-Gallon Pail," Jechnical Support Document - Type A Study, MLM-2229(1975). 


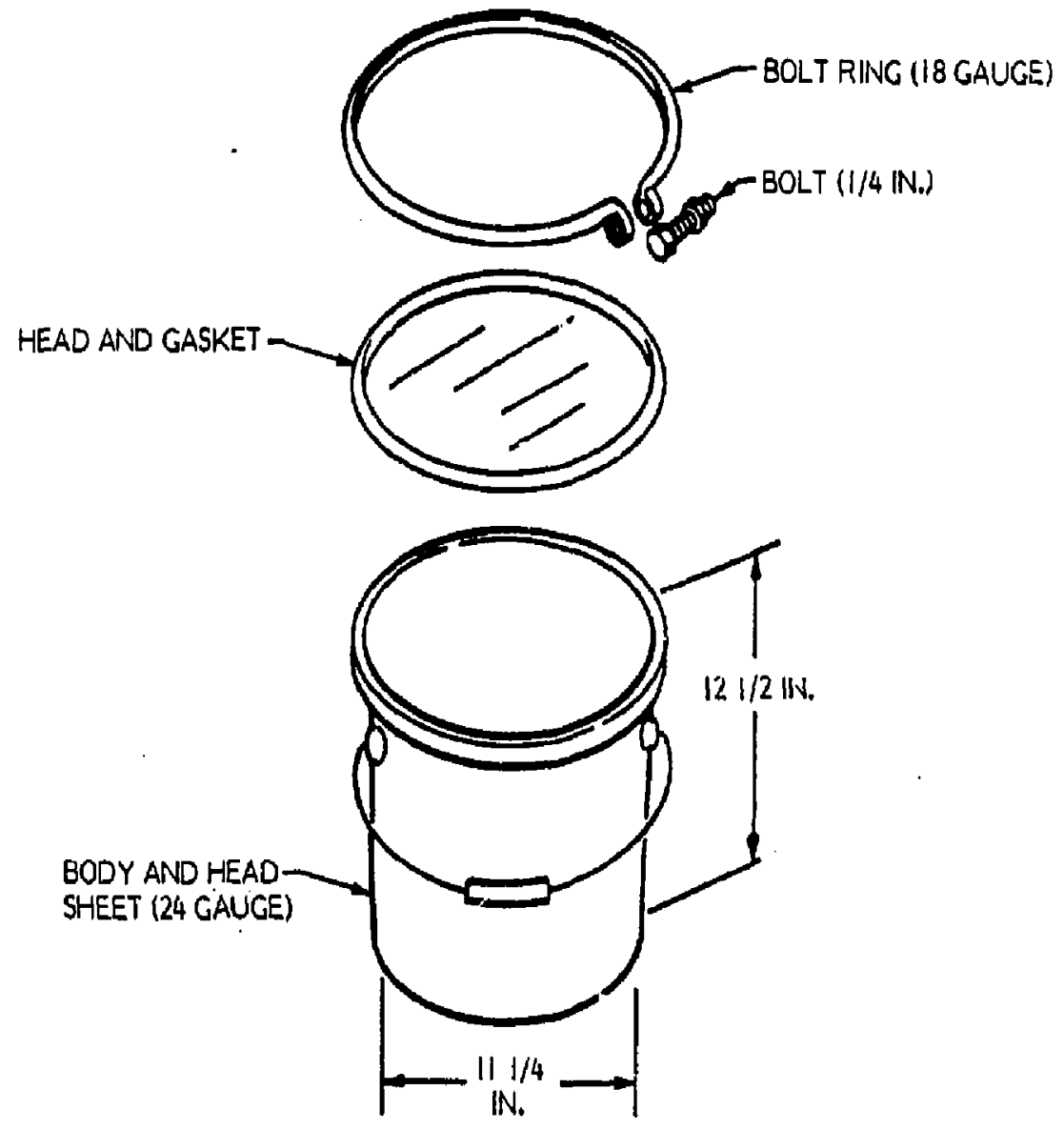

FIGURE 4-23

DOT SPECIFICATION ITC STEEL DRUM (CFR49 178.115) - 5 gallon (1.3L) 
TABLE 4-22

DOT SPECIFICATION I7C

1) Common iName of Container:

Spec 17C 55 Gollon Steel Drum (208-liter)

2) Authorized Contents:

Type "A" quantities of solid radioactive moterial in normal or special form.

3) Dimensions:

Interior $-22 \psi_{2}$ in. ID $\times 33 \psi_{4}$ in. usoble inside height

Exterior -24 in. OD $\times 35$ in. outside height

4. Description of Container:

$55 \mathrm{gol}$ Spec $17 \mathrm{C}$ steel drum

16 gauge body and head sheets

Gaskets (see item 5)

5) Specificotions and Restrictions:

- Authorized Gross Weight - 840 ib

- Any bulky equipment with sharp corners, protrusions, etc., must be securely positioned within drum.

- Gasket material must have minimum aperating range of $-40^{\circ} \mathrm{F}$ to $+130^{\circ} \mathrm{F}$. If sponge rubber gaskets ore used, minimum of $k \mathrm{in}$. required.

6) Test Results:

\section{Environmental Conditions}

Test

Results

Discussion ond/or Reference

a) Heat, $+130^{\circ} \mathrm{F}$ Pass

Engineering Analysis (EA) - Temperoture is within normal operating ronge for materials of construction.

b) Cold, $-40^{\circ} \mathrm{F} \quad$ Poss

EA - Temperature is within normal operating range for materiols of construction.

d) Vibration Pass

Containers have withstood years of tronsport with no occurrence of significant damage due to normal vibration. 
TABLE 4-22

(CONT.)

Test Results Discussion and/or Reference

Test Conditions
e) Water Sproy
Not
Required
f) Free Drop ( $4 \mathrm{ft}$.$) Pass$
$E A-17 H-55 \mathrm{gal}$ drum of lesser wall thickness successfully passed this test, of $843 \mathrm{lb}$; hence, $17 \mathrm{C}$ would poss.
g) Corner Drop
Pass
I Not required unless packoge is shipped as Fissile Class 11. CFR49 173.398(b)(3)(iii). Although $17 \mathrm{C}$ drum (gross wt. $500 \mathrm{lb}$ was tested and found to pass per letfer W. F. Romine to G. Rousseau, Feb. !, 1968. "Spec 17C 55-Gollon Steel Drum," Technical Support Document - Type A Study, MLMA-2229 (1975).
h) Penetrotion Pass
Letter W. F. Romine to G. Rousseau, Feb. I, 1968. "Spec. 17C 55-Gollon Steel Drum," Technical Support Document - Type A Study, MLM-2229(1975).
i) Compression Pass
Letter W.F. Romine to G. Rousseay, Feb. 1, 1968. "Spec 17C 55-Gollon Steel Drum," Technical Support Document - Type A Study, MLM-2229 (1975). 


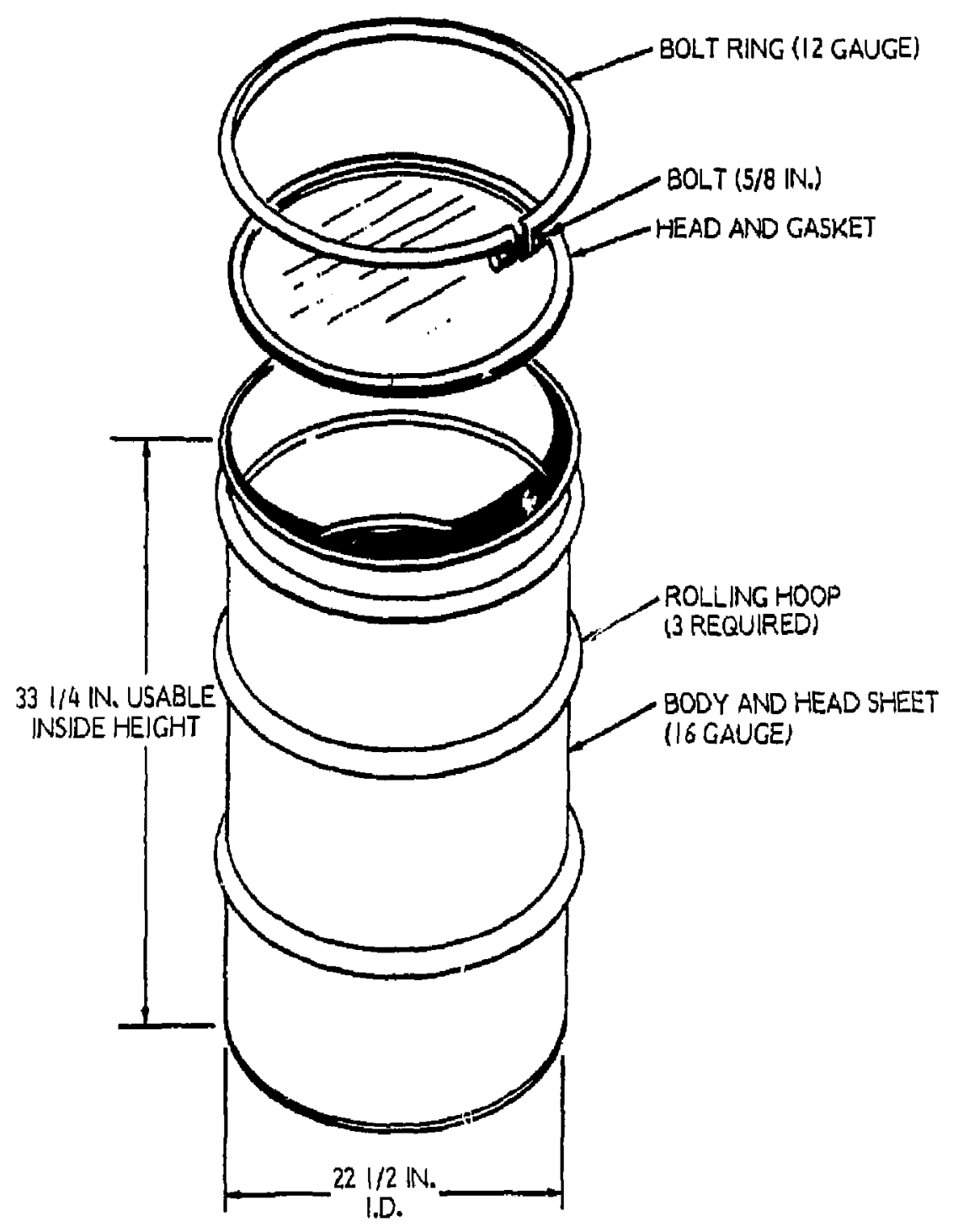

FIGURE 4-24

DOT SPECIFICATION I7C STEEL DRUM (CFR49 (78.1 15) - 55 gallon (208-L) 
TABLE 4-23

DOT SPECIFICATION I7H STEEL ORUM

1) Common Name of Container:

Spec 17H 30 Gallon (14-Liter) Steel Drum

2) Authorized Cont: nts:

Type "A." quantities of salid radioactive material in normal or special form

3) Dimensions:

Interior - 18 in. 1.d. $\times 28$ in. usoble inside height

Exterior - $20 \mathrm{in}$. 0.d. $\times 29 \%$ in. outside height

4. Description of Contoiner:

30-gallon Spec. I7H steel drum

18 gouge wall, bottom ond top head sheet

Cosket reruired (see item 5).

5) Specifications und Restrictions:

- Authorized Gross Weight - 500 ib (227 kg)

- Any bulky equipment wit'- sharp corners, protrusions, etc., must be securely positioned within drum.

- Gasket material must have minimum operating range of $-40^{\circ} \mathrm{F}$ to $+130^{\circ} \mathrm{F}$. If sponge rubber goskets are used, minimum of $k_{2}$-in. required.

6) Test Results:

\section{Environmental Conditions}

Test Results Discussion and/or Reference

a) Heat, $+130^{\circ} \mathrm{F}$ Pass Engineering Analysis (EA)-Temperature is within normal operoting ronge for materials of construction.

b) Cold, $-40^{\circ} \mathrm{F} \quad$ Pass

EA - Tempergture is within normal operating range for moterials of construction.

c) Reduced Pressure Pass

"Spee 17H 30-Gollon Steel Drum," Technical Support Document - Type A Study, MLM-2229 (1975):

d) Vibrotion Pass

Containers hove withstood years of tronsport with no occurrences of significont damoge due to normol vibrotion. 
TABLE 4-23

(CONT.)

\section{Test Conditions}

\begin{tabular}{|c|c|c|}
\hline Iest & Results & Discussion and/or Reference \\
\hline e) Woter Sproy & $\begin{array}{l}\text { Not } \\
\text { Required }\end{array}$ & CFR49 173.398 (b) (3) (i) \\
\hline f) Free Drop & Pass & $\begin{array}{l}\text { Tested with gross weight of } 500 \mathrm{lb} \text {. } \\
\text { "Spec 17H 30-Gollon Steel Drum," Tech- } \\
\text { nical Support Document - Type A Study, } \\
\text { MLM-29225(1975). }\end{array}$ \\
\hline g) Corner Drop & $\begin{array}{l}\text { Not } \\
\text { Required }\end{array}$ & $\begin{array}{l}\text { As long as packuge is Fissile Class I or } \\
\text { exempt. CFR49 } 173.398 \text { (b) (3) (iii). }\end{array}$ \\
\hline h) Penetration & Poss & $\begin{array}{l}\text { EA - Drums of equal gouge have consist- } \\
\text { ently possed this test. ORNL-TM-3468, } \\
\text { December, } 1972, P .77 \text {. }\end{array}$ \\
\hline i) Compression & Pass & $\begin{array}{l}\text { Tested with } 2600-1 \mathrm{~b} \text { "Spec } 17 \mathrm{H} \\
\text { 30-Gallon Steel Drum," } \\
\text { Support Document - Type A Study; } \\
\text { MLM-2229(1975). }\end{array}$ \\
\hline
\end{tabular}




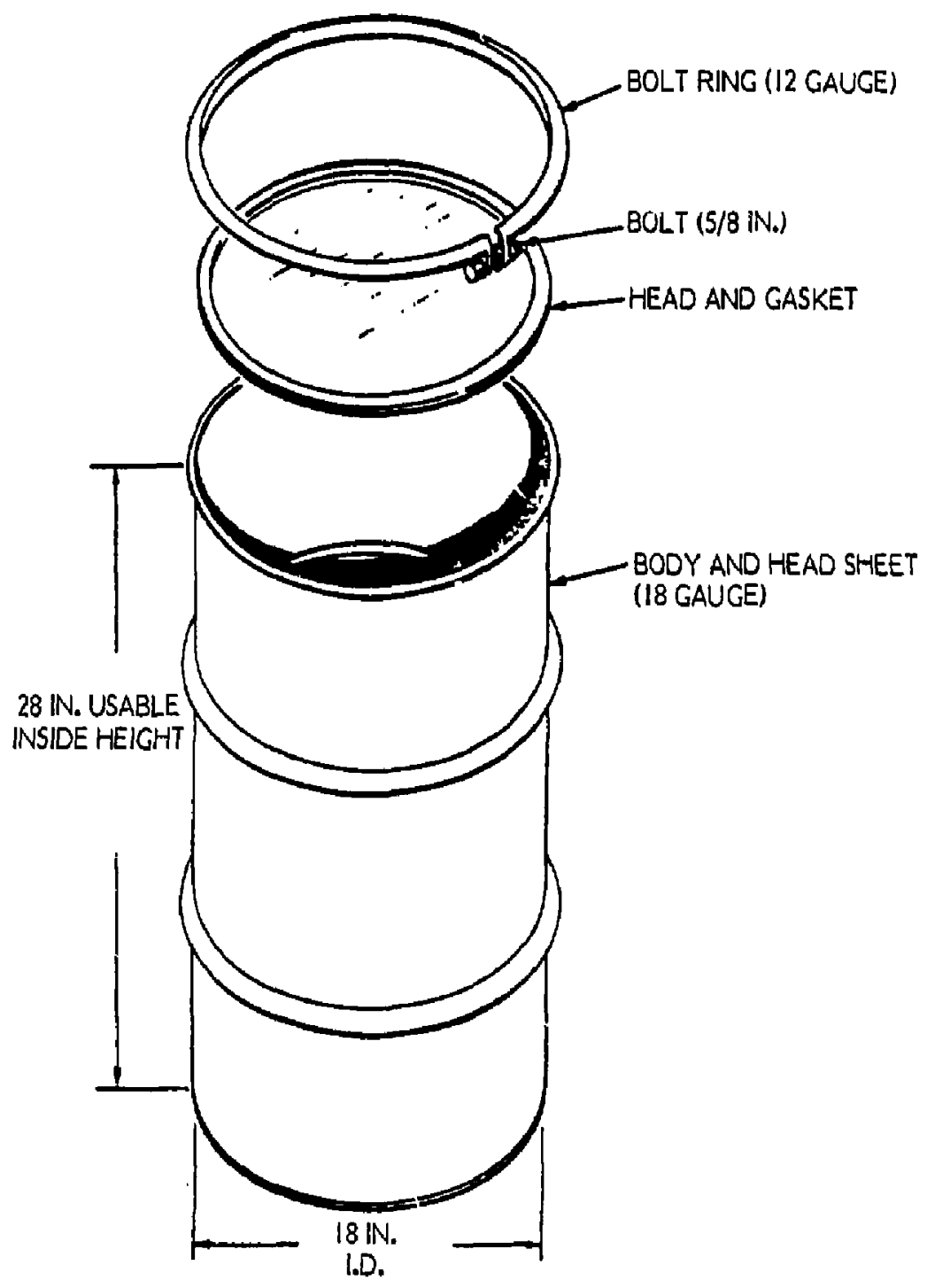

FIGURE 4-25

DOT SPECIFICATION I7H STEEL DRUM

(CFR49 178.118) - 30 gallon (114-L) 


\section{TABLE 424}

\section{DOT SPECIFICATION I7H STEEL DRUM}

1) Common Nome of Container:

New Brunswick's Spec 7A Shipping Containers

2) Authorized Contents:

Type "A" quantities of solid or liquid" radioactive moteriol in normat or special form.

3) Dimensions:

I7H

Interior - 30-gallon (I14-liter) steel drum: 18 in, i.d. $\times 28$ in. usable height

Exterior -20 in. 0.d. $\times 29 \mathrm{k}$ in. outside height

5-gallon polyethylene corboy

Exterior - approximately $\|$ in. o.d. $x$ approximately 20 in. overall height including cap

4. Description of Container:

30 gallon $17 \mathrm{H}$ open-head steel drum with a 5-gal polyethylene carboy positioned/centered with absorbent material - vermiculite or equivolent.

$17 \mathrm{H}$ steel drum

- 18 gauge side, head and bottom sheets.

- $5 / 8$ in. bolt and 12 gouge ring.

- Casket required.

5-gollon polyethylene carboy - Nalgene Co. or equivalent.

- Screw cap with $2 k$ in. i.d. opening

- Catalogue No. 2238-0050

- $\quad 1 / 8$ in. minimum wall thickness

5) Specifications and Restrictions:

- Authorized gross weight - $102 \mathrm{lb}$.

- Gasket material must have minimum operating range of $-40^{\circ} \mathrm{F}$ to $+130^{\circ} \mathrm{F}$. If sponge rubber gosket is used, minimum of $\mathrm{z}_{2}-\mathrm{in}$. required.

- Absorbent material capable of absorbing twice the quantity of liquid required.

- Secure tightening of carboy cap. Tape or equivalent recommended around outside of cop.

This package was given the 30-ft drop test and no liquid was released frem the primary container (polyethylene corboy; the absorbent meets the requirements of $\mathrm{HM}-11 \mathrm{I}, 173.393 \mathrm{ig})(2)$ and the $17 \mathrm{H}$ steel drum meets the requirements of $H M-111,173.393(g)(3)$. 
TABLE 4-24

(CONT.)

\section{Test Results Discussion and/or Reference}

6) Test Results:

\section{Environmental Conditions}

Test

a) Heat, $+130^{\circ} \mathrm{F}$

b) Cold, $-40^{\circ} \mathrm{F}$

c) Reduced Pressure

Pass

d) Vibration

Poss

\section{Discussion anf/or Reference}

Engineering Analysis (EA) - Temperature is within normal ronge for moterials of construction.

EA - Temperature is within normal ronge for moterials of construction.

"New Brunswick's Spec 7A Shipping Contoiners," Technical Support Docu= ment - Type A Study, MLM-2229 (1975).

Containers hove withstood years of transport with no occurrence of significont damage due to normal vibrotion.

\section{Test Conditions}

e) Water Sproy

Not

Required

f) Free Drop (4 ft.) Poss

$17 \mathrm{H}$ (30 gal). Tested with gross weight of $513 \mathrm{lb}$. "New Brunswick's Spec 7A Shipping Contoiners," Technical Support Document - Type A Study, MLM-2229 (1975).

$(30 \mathrm{ft})$

Poss

Tested with gross weight of $102 \mathrm{lb}$. "New Brunswick's Spec 7A Shipping Contoiners," Technical Support Document Type A Study, MLM-2229 (1975).

g) Corner Drop

Not

Required

As long as package is Fissile Class I or exempt. CFR49 173.398 (b) (3) (iii).

h) Penetration Pass

EA - Equivalent gouge metol tested for $55 \mathrm{gal} 17 \mathrm{H}$.

17H (30 gal). Tested with $2600 \mathrm{lb}$ load. "Spec 17H 30-Golion Steel Drum," Technical Support Document - Type A Study, MLM-2229 (1575). 


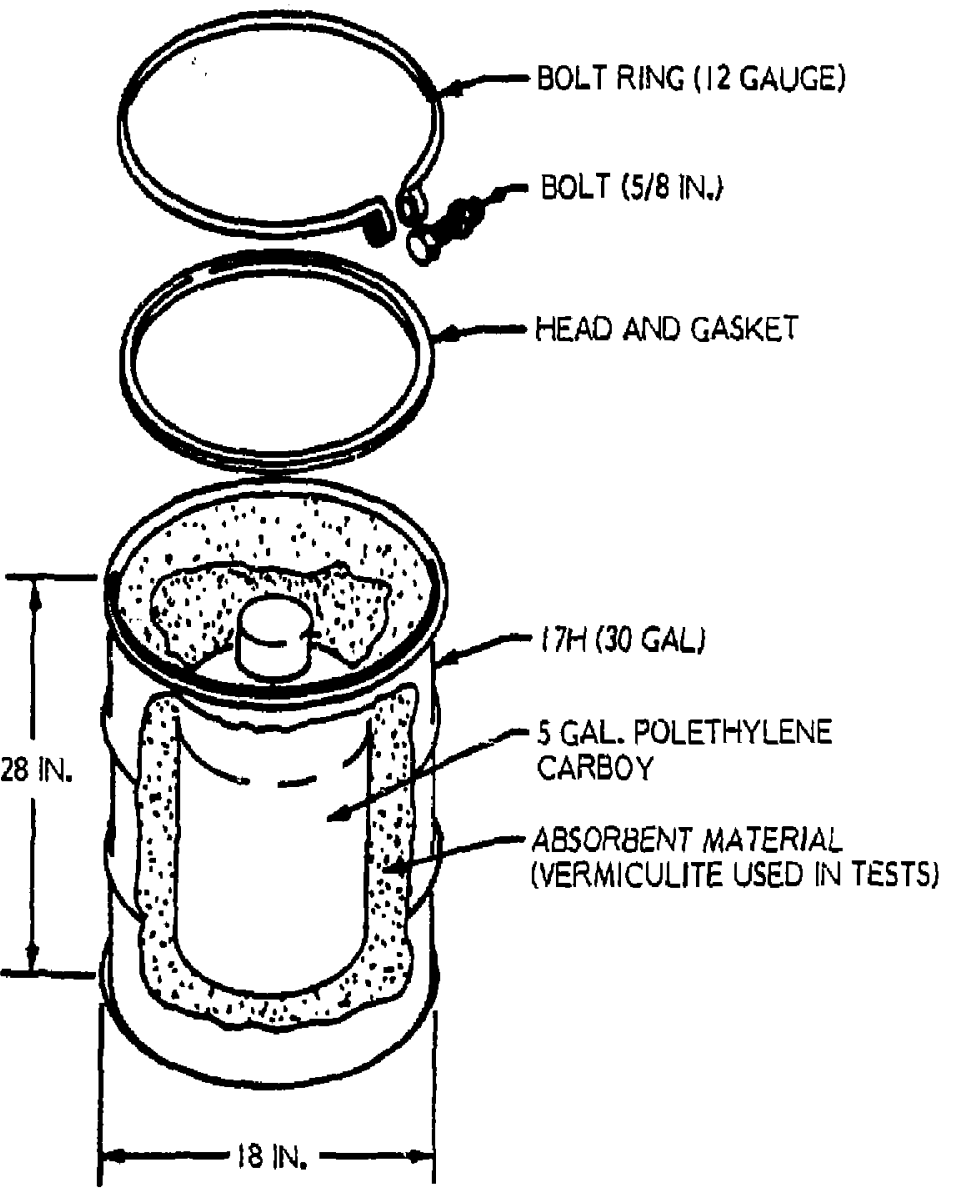

FIGURE 4-26

DOT SPECIFICATION I7H STEEL DRUM (30 gallon) WITH 5-GALLON POLYETHYLENE CARBOY - (CFR49 178.118) 


\section{TABLE 4-25}

DOT SPECIFICATION I7H STEEL DRUN.

I. Common Name of Container:

Spec 17H 55-Gallon (208-L) Steel Drum

2. Authorized Contents:

Type "A" quantities of solid radioactive moterial in normal or special form.

3. Dimensions:

Interior: 22-1/2 in. i.d. $\times 33-1 / 4$ in. usable inside height

Exterior: 24 in. 0,d. $\times 35$ in, outside height

4. Description of Container:

55-gal Spec 17.4 stee! drum

18 gouge sides and bottom head sheet

14 or 16 gauge removable head sheet (16 gauge authorized provided there are one or more corrugations in, the cover near the periphery) Gasket (see item 5)

5. Specifications and Restrictions:

- Authorized Gross Weight - $840 \mathrm{lb}(38 \mathrm{l} \mathrm{kg})$

- Any bulky equipment with shorp corners, protrusions, etc. must be secur ely positioned within drum.

- Casket material must have minimum operating range of $-40^{\circ} \mathrm{F}$ to $+130^{\circ} \mathrm{F}$. If sponge rubber gasket is used, minimum of 1,2 in. required.

6. Test Results:

\section{Environmental Conditi.jns}

Test

Results

Discussion and/or Reference

a) Heat, $+130^{\circ} \mathrm{F}$

Pass Engineering Analysis (EA) - Temperoture is within normal operating range for materials of construction.

b) Cold, $-40^{\circ} \mathrm{F}$

Pass

EA - Temperature is within normal operating range for materials of construction. 
TABLE 4-25

(CONT.)

Test

c) Reduced Pressure

d) Vibrotion

e) Water Spray

f) Free Drop (4 ft.!

g) Corner Drop

h) Penetration

i) Compression
Results Discussion und/or Reference

Pass $\quad$ "Spec 17H 55-Gallon Steel Drum," Technical Support Document - Type A Study, MLM-2229 (1975).

Poss Containers have withstood years of tronsport with no occurrense of significant damage due to normal vibration.

\section{Test Conditions}

Not CFR49 fara. 173.398 (b) (3) (i)

Required

Pass Tested with $843 \mathrm{Ih}$ gross weight. "Spec $17 \mathrm{H}$ 55-Gallon Steel Drum," Tecinicol Support Document - Type A Study, MLNi-2229 (1975).

Not As long os packages are Fissile Closs I or Required exempt. CFR49 para. 173.358 (b) (3) (iii).

Pass "Spec 17H 55-Galion Steel Drum," Technical Support Document - Type A Study, MLM-2229 (1975). ORNL-TM-3468, December 1972, poge 77.

Pass Tested with $4600 \mathrm{lb}$ load. "Spec 17H 55-Gollon Steel Drum," Technical Support Document Type A Study, MLM-2229 (1975). 


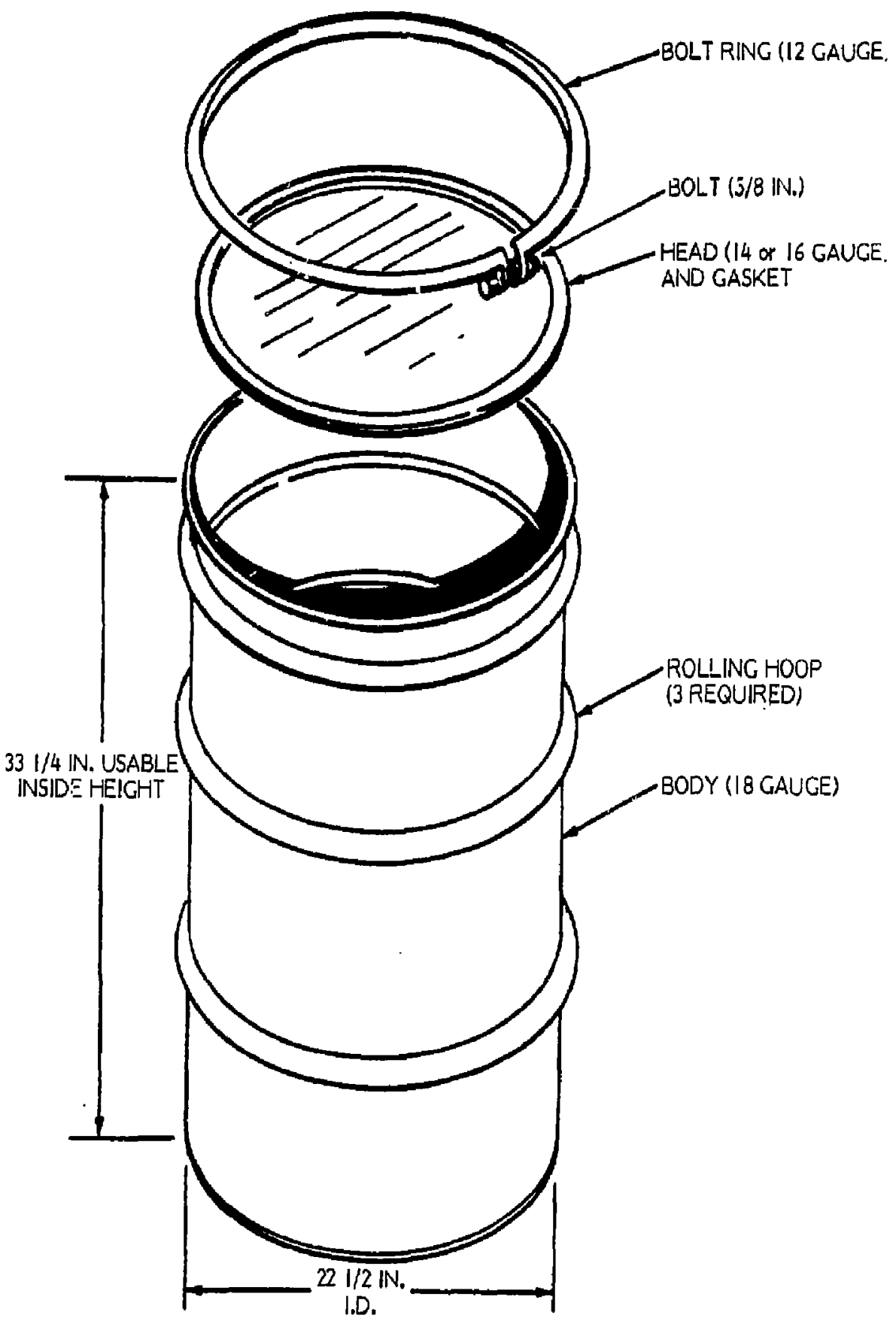

FIGURE 4-27

DOT SPECIFICATION I7H STEEL DRUM

(CFR49 178.IIB) - 55 gallon (208-L) 


\section{TABLE 4-26}

\section{DOT SPECIFICATION I5A - XXX WOODEN BOX}

1) Common Name of Container:

Spec 15.A - XXX Wooden Box'

2) Authorized Contents:

Type "A" quantities of solid radioactive materials in normol or special form.

3) Dimensions:

Box sizes tested and determined to meet Spec 7A criterio.

\begin{tabular}{|c|c|c|}
\hline $\begin{array}{l}\text { Width } \\
\text { (in.) }\end{array}$ & $\begin{array}{c}\text { Height } \\
\text { (includes } \\
\text { thickness } \\
\text { of cover) } \\
\text { (in.) }\end{array}$ & $\begin{array}{l}\text { Length } \\
(\text { in. }\end{array}$ \\
\hline $\begin{array}{c}8 \\
24 \\
13-1 / 2 \\
5\end{array}$ & $\begin{array}{r}8 \\
24 \\
13 \\
5\end{array}$ & $\begin{array}{l}8 \\
24 \\
21-1 / 4 \\
20\end{array}$ \\
\hline
\end{tabular}

4) Description of Container:

Spec 15A - XXX Wooden Box ${ }^{\top}$ - styles 2, 2 I/2, 3 (CFR49 178.168-12 (d))

Fully cleated ends/double cleated

All joints except lid closure glued with woterproof recorsinal glue or equivolent

Lid closure by \#IOFHS screw $\times 2$ in. - Naximum spacing 3 in. all around, but equivalent nailed closure is acceptable

Sides, top and bottom - 3/4 in. A/C Exierior Plywood

Finds and cisotes -1 in. thick clear white pine

Tw' s'rids - 2 in. $x 4$ in. - No. I construction

Nailing frequency - $13 / 4$ in. moximum separation

5) Specifications and Restrictions:

\begin{tabular}{lc}
$\begin{array}{l}\text { Box Size } \\
\text { (in.) }\end{array}$ & $\begin{array}{c}\text { Gross Weight } \\
(\text { (b) })\end{array}$ \\
\cline { 2 - 2 } $\begin{array}{c}8 \times 8 \times 8 \\
24 \times 24 \times 24\end{array}$ & 44 \\
$131 / 2 \times 13 \times 211 / 4$ & 335 \\
$5 \times 5 \times 20$ & 220 \\
& 47
\end{tabular}

INote: $X X X$ to be replaced by outhorized gross weight for package. 


\section{TABLE 4-26}

(CONT.)

- Materiols must be securely positioned within the box

- Not authorized for air transport unless sealed inner container, copoble of meting reduced pressure criteria CFR49 173.398 (b) (2) (iii) is used

- All joints glued with waterproof recorsinal glue or equivalent

\section{6) Test Results:}

\section{Environmental Conditions}

\section{Test}

a) Heat, $+130^{\circ} \mathrm{F}$

b) Cold, $-40^{\circ} \mathrm{F}$

c) Reduced Pressure

d) Vibration

g) Corner Drop

h) Penetrotion

Pass

\section{Discussion and/or Reference}

Engineering Analysis (EA) - Temperature is within normal operating ronge for materials of construction.

EA - Temperoture is within normal operoting range for materials of construction.

Packaging expected to "breathe," therefore, restricted from air transport unless certain provisions mode. See item 5.

Containers have withstood years of transport with no occurrences of significant damoge due to normal vibration.

\section{Test Conditions}
e) Water Spray
Not
CFR49 173.398 (b) (3) (j)
Required
f) Free Drop $(4 \mathrm{ft}$.$) Poss$
Tested with gross weight outhorized, "Spec 15A - Wooden Box, Technical Support Document - Type A Study, MLM- 2225 (1975).

Treated with load of $110 \mathrm{lb}$ or greater. "Spec 15A - Wooden Box," Technical Support Document - Type A Study, MLM-2229 (1975).

"Spec 15A - Wooden 8ox," Technical Support Document - Type A Study, MLM-2229 (1975). 


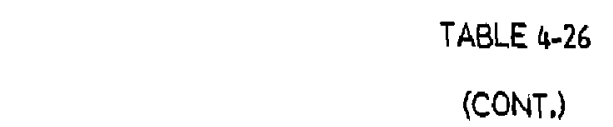

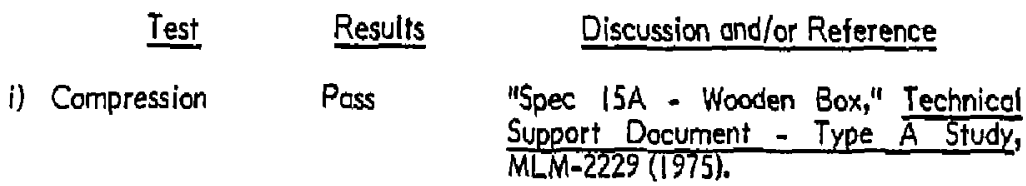

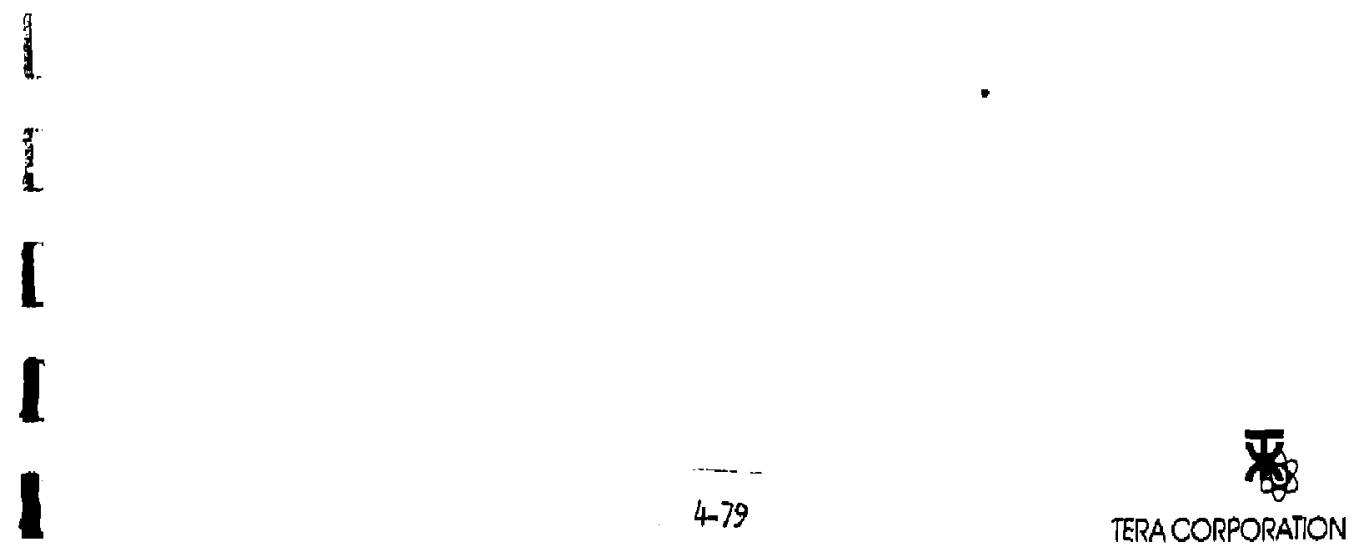




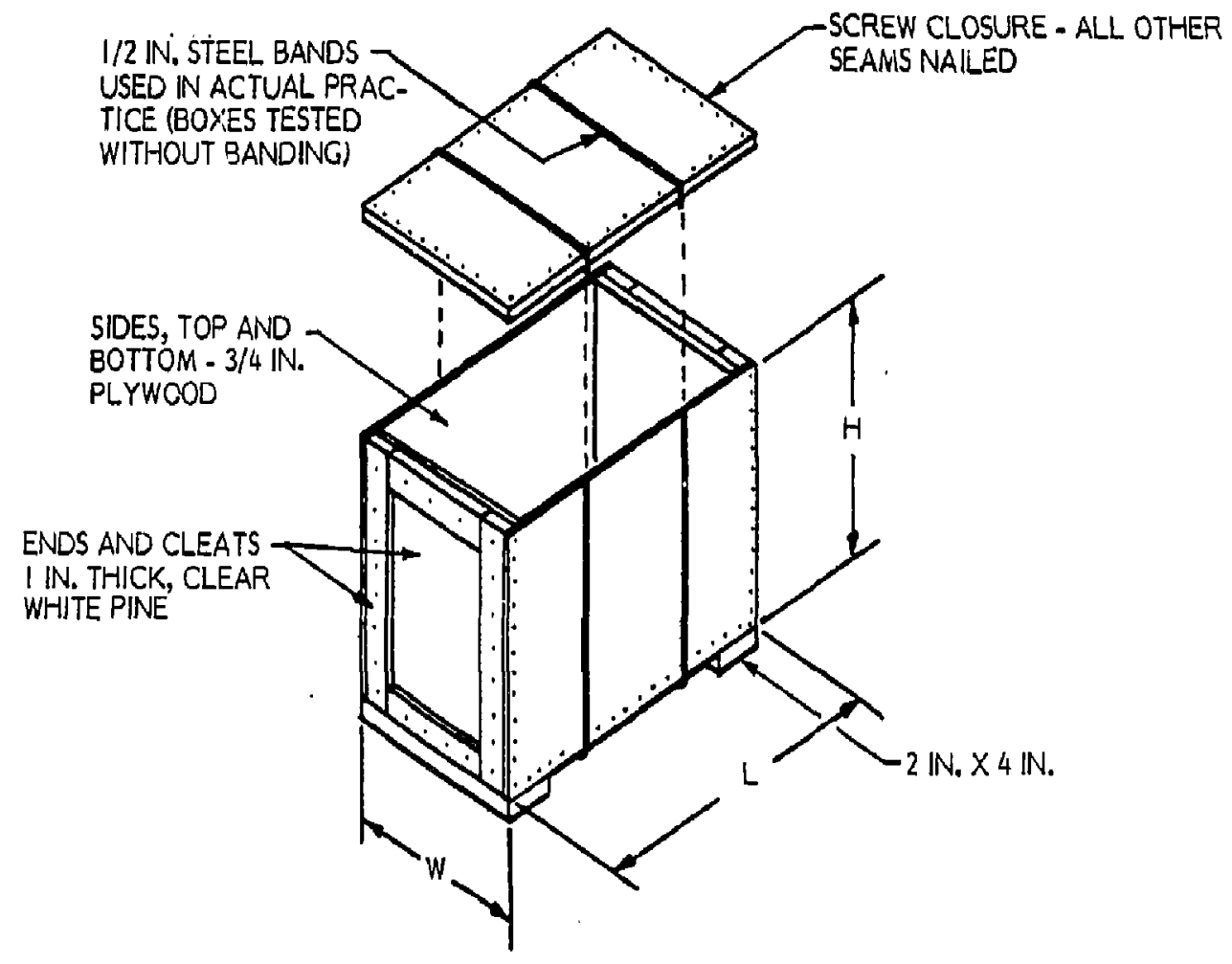

FIGURE 4-28

DOT SPECIFICATION I5A - XXX WOODEN BOX

(CFR49 178.168) 
TABLE 4-2/

DOT SPECIFICATION I5A - XXX WOODEN BOX

1) Common Name of Contairis:

Spec 15A - XXX Wooden Boxes', Style I

2) Authorized Contents:

Type "A" quantities of solid radiooctive material in normol or special form.

3) Dimensions:

Exterior dimensions of box sizes tested and determined to meet Spec 7A criteria.

\begin{tabular}{|c|c|c|}
\hline$W($ in.) & $H\left(i_{0}\right)$ & $L\left(\right.$ in. $\left._{0}\right)$ \\
\hline $\begin{array}{c}3(1 / 2 \text { in. white pine) } \\
8(3 / 4 \text { in. plywood) } \\
12 \text { (3/4 in. plywood) } \\
8 \text { (3/4 in. plywood) } \\
4(3 / 4 \text { in. plywood) }\end{array}$ & $\begin{array}{c}8(1 / 2 \text { in. white pine) } \\
8(3 / 4 \text { in. plywood) } \\
12(3 / 4 \text { in. plywood) } \\
8(3 / 4 \text { in. plywood) } \\
4(3 / 4 \text { in. plywood) }\end{array}$ & $\begin{array}{c}32 \text { (1/2 in. white pine } \\
8 \text { (3/4 in. plywood) } \\
12(3 / 4 \mathrm{in} \text {. plywood) } \\
32 \text { (3/4 in. plywood) } \\
16 \text { (3/4 in. plywood) }\end{array}$ \\
\hline
\end{tabular}

4. Description of Container:

Spec I5A - XXX, Style I

Nailed boxes (including closure), not cleated.

All construction of $3 / 4$ in. plywood with the ex: aption of the 8 in. $\times 8$ in. $\times 32$ in. box of white pine.

5) Specifications and Restrictions:

$$
\begin{gathered}
\text { Box Size } \\
\text { (in.) } \\
\hline
\end{gathered}
$$

$8 \times 8 \times 8(3 / 4$ in. plywood)

$4 \times 4 \times 16(3 / 4$ in. plywood)

$12 \times 12 \times 12$ (3/4 in. plywood)

$8 \times 8 \times 32$ (white pine)

$8 \times 8 \times 32$ (3/4 in. plywood)
Authorized Gross Weight

(ib)

21

100

40

100

- Any bulky equipment with sharp corners, protrusions, etc., must be securely positioned within box.

- Not outhorized for air tronsport unless sealed inner contoiner, capable of meeting reduced pressure criteria is used.

Note: $X X X$ to be replaced by outhorized gross weight for package. 
6) Iest Results:

\section{Environmentcl Conditions}
Test
Results
Discussion ond/or Reference
a) Heat, $+130^{\circ} \mathrm{F}$
Poss
Engineering Anolysis (EA) - Temperature is within normal operoting range for materials of construction.
b) Cold, $-40^{\circ} \mathrm{F} \quad$ Pass
EA - Temperature is within normal operating range for materials of con- struction.
c) Reduced Pressure
Not
Packaging expected to "breathe," there-
Tested fore, restricted from oir transport unless certain provisions made. See item 5.
d) Vibration Pass
Containers have withstood years of transport with no occurrences of signifi- cant damage due to normal vibration.

\section{Test Conditions}
e) Water Spray
Not
CFR49 173.398 (b) (3) (i)
Required

f) Free Drop ( $4 \mathrm{ft}$.$) Pass$

Tested with outhorized gross weights. "Spec 15A - XXX Wooden Boxes, Style 1," Technical Support Document - Type A study, MLM-22229(1375).

g) Corner Drop Pass

Tested with authorized gross weights. "Spec 15A - XXX Wooden Boxes, Style $1_{1}$ "Technical Support Document - Type A Study, MLM-2229 (1975).

h) Penetration Poss Tested. "Spec 15A - XXX Wooden Boxes, Style 1," Technical Support Document -Type A Study, MLM-2229 (1975).

i) Compression Poss Tested, "Spec I5A - XXX Wooden Boxes, Style 1," Technical Support Document - Type A Study, MLM-2229 (1975).

7) For Additional Information Contact:

D. A. Edling

Monsanto Research Corporation Mound Laboratory

P. O. Box 32

Miamisburg, Ohio 45342 


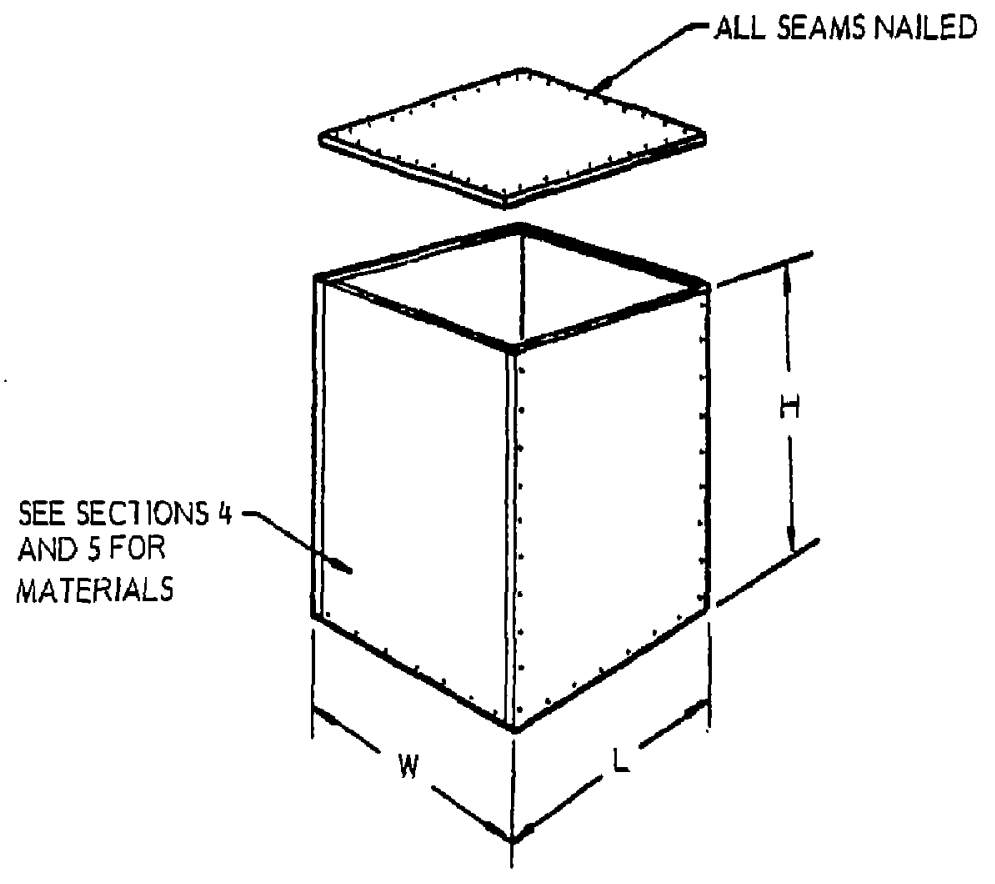

FIGURE $4-29$

DOT SPECIFICATION ISA - XXX WOODEN BOX

(CFR49 (78.168)

I

I 
1) Common Name of Contoiner:

Spec |5A-75, Style I

2) Authorized Contents:

Type "A" quantities of liquid" or solid radiooctive matericls in normal or special form.

3) Dimensions:

Box

Imtarior $-32-1 / 2$ in. length $\times 6-1 / 2$ in, width $\times 3-1 / 2$ in. height

Exterior $-35-1 / 2$ in. length $\times 8$ in, width $\times 5$ in. height

Pipes with Cops $-3-1 / 2$ in. i.d. $\times 30$ in. length

4) Description of Container:

Spec |5A-75, Style |

Sides, top and bottom - $11 / 16$ in, yellow pine or equivalent

Ends -2 in. $x 4$ in. - No. I construetion

Closure by No. 8, 1-1/2 in. wood screws - three evenly spaced per side and enc', but equivalert nailed closure is acceptable

Two Schedule 80 pipes with screw caps placed inside box

Teflon tape or equivolent placed on pipe threods

Pipe nipple wropped in $1 / 4$ in. polyfoam

Boxes banded with $3 / 4$ in. glass filament tape** or equivalent.

5) Specifications and Restrictions:

- Authorized Gross Weight - $75 \mathrm{lb}$

- Abosorbent material placed within pipe nipple cepable of obsorbing twice the volume of liquid contained

- Not authorized for air transport

6) Test Results;

\section{Environmental Conditions}
Test
Results
Discussion and/or Reference
a) Heat, $+130^{\circ} \mathrm{F}$
Pass
Engineering Analysis (EA) - Temperature is within normal operoting range for materials of construction.

\footnotetext{
* This packoge wos given the 30-ft drop test and no liquid wos released from the primory container (pipe nipple with screw caps).

* The tape was used in the 30-ft drop test but not in the 4-ft drop test.
} 
TABLE 4-28

(CONT.)
Test
Results
Discussion and/or Reference
b) Cold, $-40^{\circ} \mathrm{F}$
Pass
EA - Temperature is within normal operating range for materials of con- struction.
c) Reduced Pressure Not
Tested
15A wood box is expected to "breothe" and there is some question os to ability of pipe/cop to retain gas leak-tightness. Hence, the restriction on oir transport.
d) Vibration
Poss
Containers have withstood yeors of tronsport with no occurrences of signifi- cont damage due to normal vibration.

\section{Test Conditions}
e) Woter Sproy
Not
Required
CFR49 173.398 (b) (3) (i)
f) Free Drop (4 ft.) Poss
Test with 75 lb gross weight. "Spec I5A- 75, Style 1," Technical Support Document - Type A Study, MLM 2229 (1975).

g) Corner Drop

Poss

Tested with $75 \mathrm{lb}$ gross weight. "Spec 15A-75, Style 1," Technical Support Document - Type A Study, MLM 2229 (1975).

h) Penetration Pass

"Spec 15A-75, Style 1," Technical Support Document - Type A Study, MLM 2229 (1975).

i) Compression Pass

"Spec 15A-75, Style 1," Technical Support Document - Type A Study, MLM 2229 (1975).

7) For Additional Information Contact:

D. A. Edling Monsonto Research Corporation Mound Loboratory

P. O. Box 32

Miamisburg, Ohio 45342 


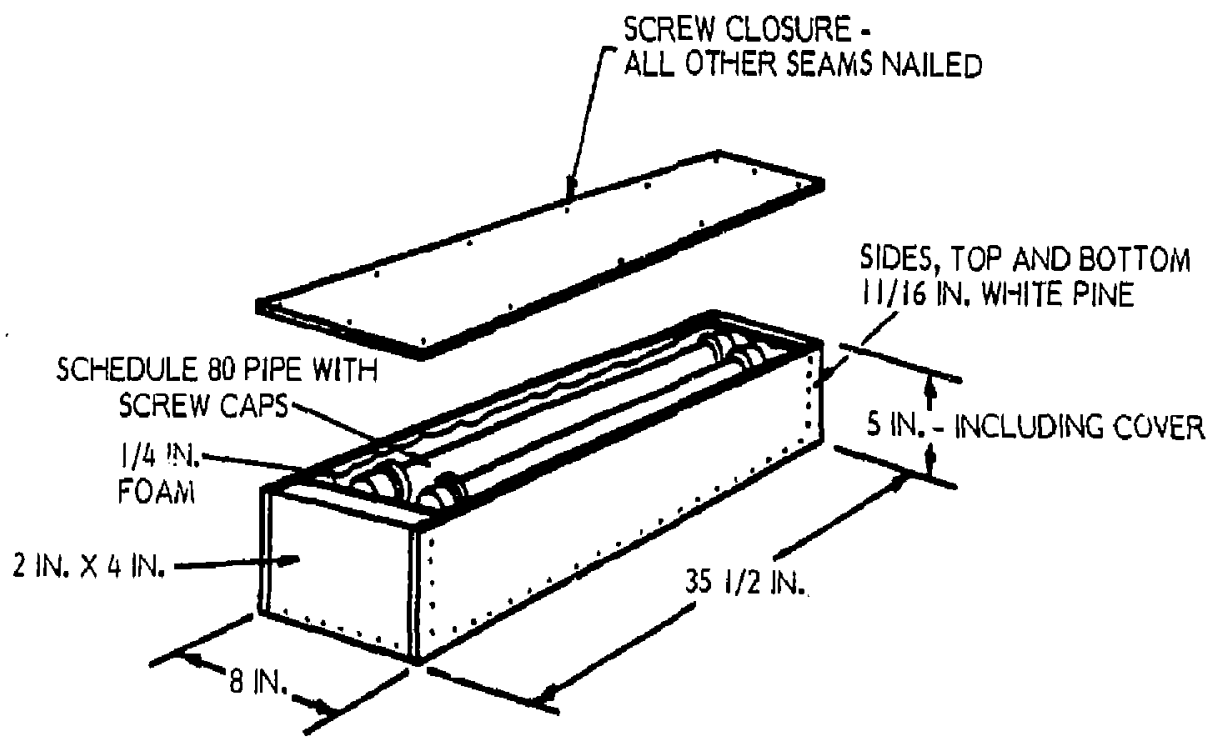

FIGURE 4-30

DOT SPECIFICATION I5A-75 WITH PIPES/SCREW CAPS

(15A - CFR49 178.168) 


\section{DOT SPECIFICATION ISA-100 WOODEN BOX}

1) Common Nome of Container:

2) Authorized Contents:

Type "A" quantities of solid radioactive material in normal or special form.

3) Dimensions:

Exterior -8 in. width $\times 6$ in. height $\times 62$ in. length

4) Description of Container:

Epec 15A wooden box with plywood interior lining on sides, top and bottom.

Sides, top and bottom - 3/4 in. pine with 1/4 in. plywrood liner

Ends - solid - two pieces, $3 / 4$ in, pine

Lid fastened with wood screws - No. 10, 2 in. FHS, but equivalent nailed closure is acceptable

Normally bonded with two $1 / 2$ in. steel bonds. However, tests were conducted without the bands.

All joints except closure, nailed and glued.

5) Specifications ond Restrictions:

- Authorized Gross Weight - $100 \mathrm{lb}$

- Not authorized for air transport unless sealed inner container capable of meeting reduced pressure criterio is used.

- Any bulky equipment with sharp corners, protrusions, etc., inust be securely positioned within box.

6) Test Results:

\section{Environmental Conditions}
Test
Results
Discussion and/or Reference
a) Heat, $+130^{\circ} \mathrm{F}$
Pass
Engineering Analysis (EA) - Temperature is within normal operaing range for moteriols of construction.
b) Cold, $-40^{\circ} \mathrm{F}$
Pass
EA - Temperature is within normal operating range for materials of con- struction.




\section{TABLE 4-29}

(CONT.)
Test
Results
Discussion ond/or Reference
$\begin{array}{ll}\text { c) Reduced Pressure } & \text { Not } \\ & \text { Tested }\end{array}$
Packaging expected tu "breothe," there- fore, restricted from oir tronsport unless certain provisions made. See item 5.
d) Vibration
Pass
Containers have withstood years of tronsport with no occurrences of signifi- cant damage due to normal vibration.

\section{Test Conditions}

e) Water Sproy

Not

Required

CFR49173.398 (b) (3) (i)

f) Free Orop ( $4 \mathrm{ft}$.)

Pass

Tested with gross weight of $100 \mathrm{lb}$. "Spec 15A-100 Wooden Box," Technical Support Document - Type A Study, MLM-2229 (1975).

g) Corner Drop

Pass

Tested with gross weight of $100 \mathrm{lb}$. "Spec 15A-100 Wooden Box," Technicol Support Document - Type A Study, MLM-2229 (1975).

h) Penetration

Puss

"Spec 15A-100 Wooden Box," Technical Support Document - Type A Study, MLM-22229(1975).

i) Compression

Poss

Tested with weight of $1000 \mathrm{lb}$ load. "Spec 15A-100 Wooden Box," Technical Support Document - Type A Study, MLM-2229 (1975). 


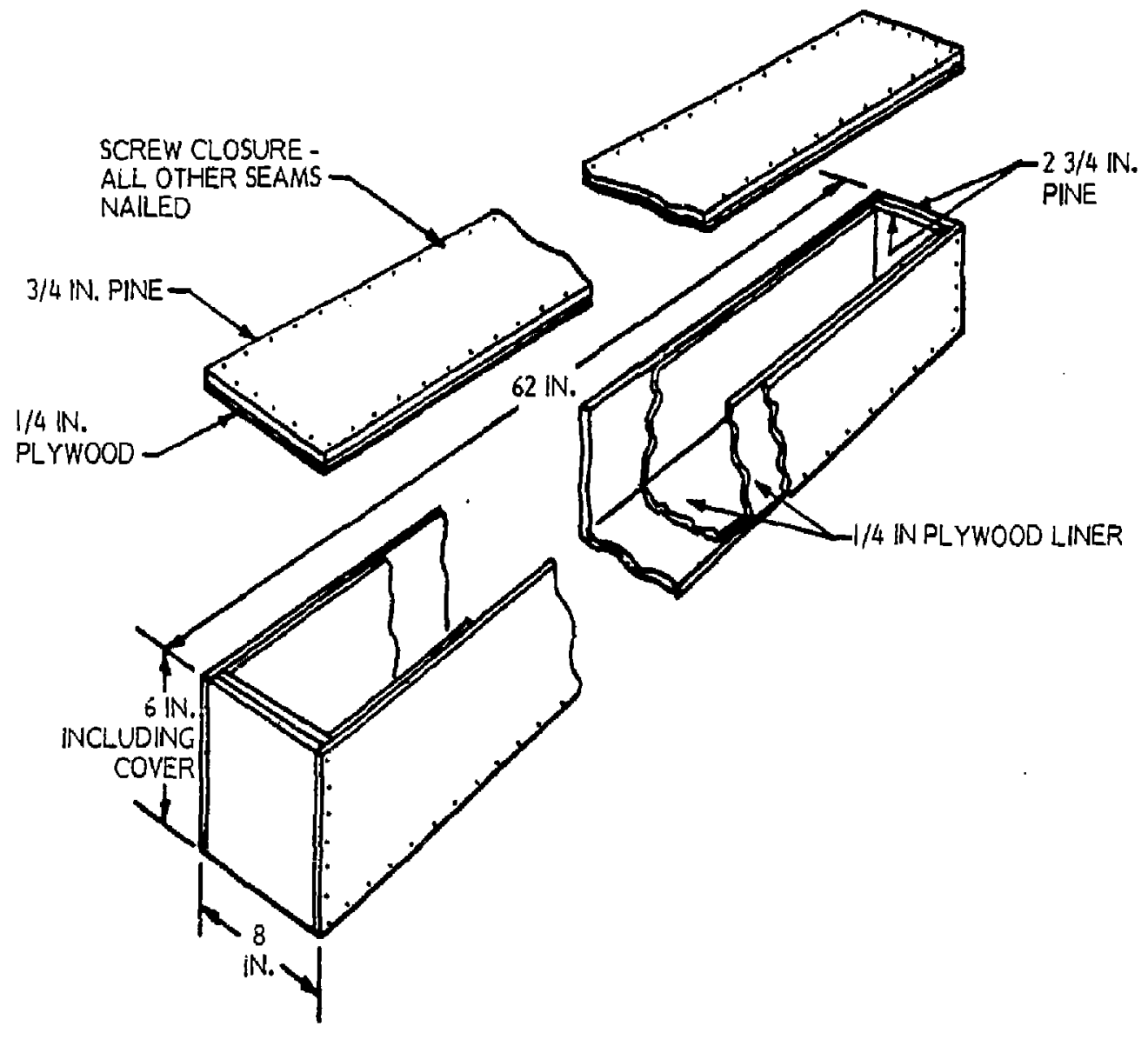

1

FIGURE 431

DOT SPECIFICATION ISA-100 WOODEN BOX

(CFP.49 178.168) 


\section{DOT SPECIFICATION 19A-XXX WOODEN BOX}

1) Common Nome of Container:

Spec 19A-XXX Wooden Boxes I

2) Authorized Contents:

Type "A" quantities of solid radioactive moterial in normal or special form.

3) Dimensions: ${ }^{2}$

Exterior dimensions of box sizes tested and determined to meet Spec 7A criterio:

\begin{tabular}{|c|c|c|}
\hline $\begin{array}{c}W \\
\text { (in.) }\end{array}$ & $\begin{array}{c}\mathrm{H} \\
\text { (in.) }\end{array}$ & $\stackrel{\mathrm{L}}{\text { (in.) }}$ \\
\hline $\begin{array}{r}12 \\
24 \\
8 \\
12\end{array}$ & $\begin{array}{r}12 \\
24 \\
8 \\
12\end{array}$ & $\begin{array}{l}\text { 12-3/4 in. plywood - screw closure } \\
24-3 / 4 \text { in. plywoad - screw clorure } \\
32-3 / 4 \text { in. plywoad - screw closure } \\
48-3 / 4 \text { in. plywood - screw closure }\end{array}$ \\
\hline
\end{tabular}

4. Description of Contoiner:

Spec 19A wooden box

3-way corners

Top, bottom and sides mode of $3 / 4$ in. plywood with noiled seams

Cleats - dimensions dependent on materials used and size of box. See CFR49 178,190-8.

NOTE: White pine cleats used for boxes tested in this report.

Screw closure but equivalent nail closure is also acceptoble.

All seams except closure nailed.

5) Specifications and Restrictions:

Box Size

(in.)

$12 \times 12 \times 12$ (3/4 in. plywood)

$24 \times 24 \times 24$ (3/4 in. plywood)

$8 \times 8 \times 32$ (3/4 in. plywood)

$12 \times 12 \times 48$ (3/4 in. plywood)
Authorized

Gross Weight

(lb)

150

400

$145^{*}$

250

* Opened slightly on one end ofter 4-ft drop test; hence, adequate inner container required, efc.

1 To be filled in with outhorized gross weight.

2 All dimensions are outside dimensions. 
- Any bulky equipment with shorp corners, protrusions, etc., must be securely positioned within box.

- Not authorized for air tronsport unless sealed inner container capoble of meeting reduced pressure criteriu (CFR49 178.398 (b) (2) (iii).

6) Test Results:

\section{Environmental Conditions}

Tast Results Discussion and/or Reference

a) Heot, $+130^{\circ} \mathrm{F} \quad$ Pass

Engineering Anolysis (EA) - Temperoture is within normal operating range for materials of construction.

b) Cold, $-40^{\circ} \mathrm{F} \quad$ Poss

EA - Temperature is within normal operating range for materials of construction.

c) Reduced Pressure Not

Pockoging expected to "breothe" thereTested fore, restricted from oir transport unless certain provisions mode. See item 5.

d) Vibration Pass

Containers have withstood years of tronsport with no occurrences of significont damage due to normal vibration.

Test Conditions

e) Woter Sproy

Not

Required

f) Free Drop ( $4 \mathrm{ft}$.$) Poss$

All packaging tested at gross weight authorized. "Spec 19A XXX Wooden Boxes," Technical Support Document Type A Sfudy, MLM-2229 (1975).

g) Corner Drop Poss

Tested of authorized gross weights. "Spec I9A XXX Wooden Boxes," Technical Support Document - Type A 5fudy, MLM-2229 (1975).

h) Penetration Pass EA - 3/4 in. plywood has consistently passed this test.

i) Compression Poss "Spec 19A XXX Wooden Boxes," Technical Support Document - Type A \$tudy, MLM-2229(1975). 


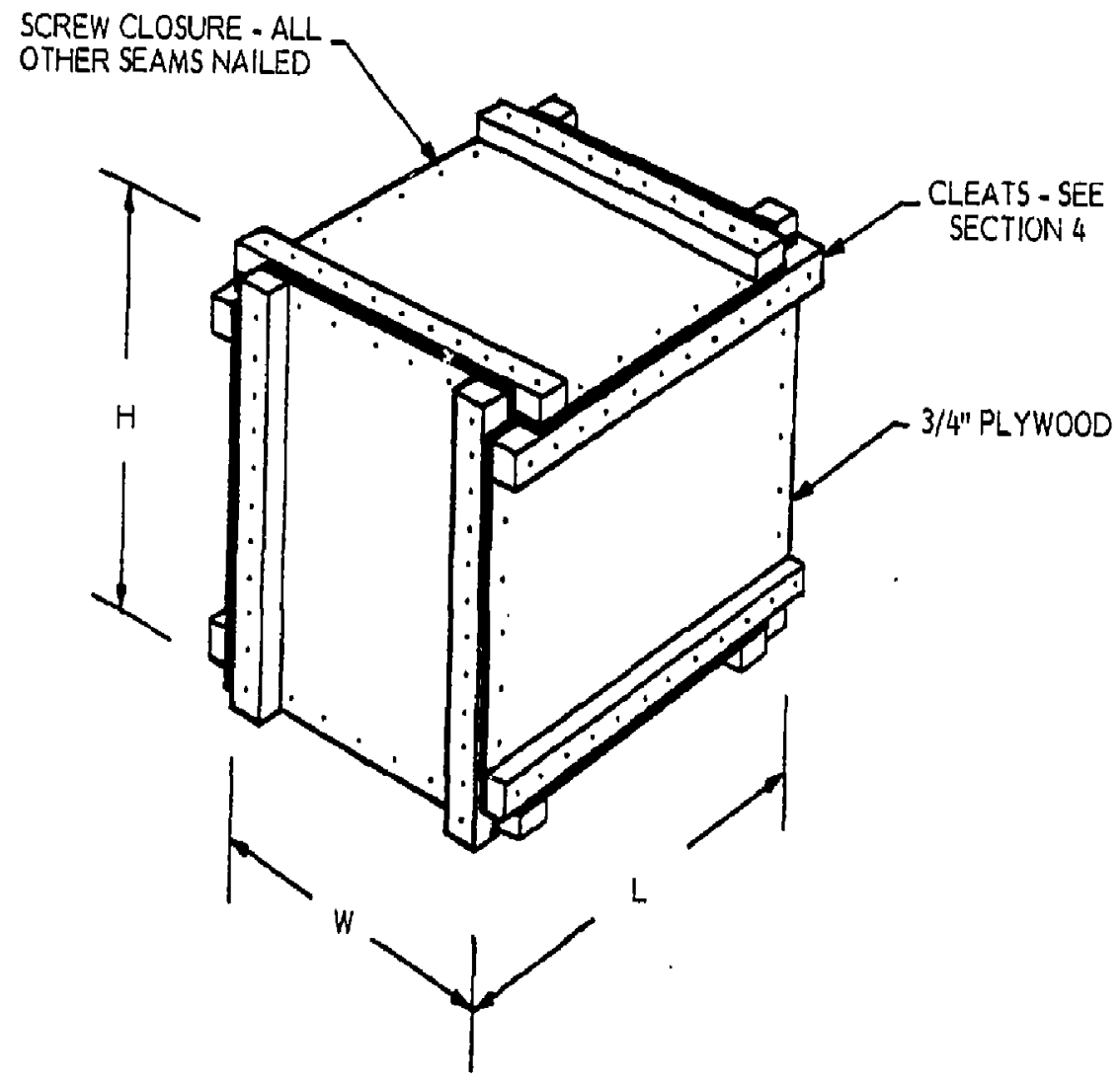

FIGURE 4-32

DOT SPECIFICATION I9A - XXX WOODEN BOX

(CFR49 178. I90) 
TABLE 4-31

DOT SPECIFICATION 19.8-150 WOODEN BOX

1) Common Name of Contoiner:

Spec 198-150 Wooden Box

2) Authorized Contents:

Type A quantities of solid radiogctive material in normal or special form

3) Dimensions:

Interior - Approximately 18 in. $\times 18$ in. $\times 18$ in.

Exterior -20 in. $\times 20$ in. $\times 20$ in.

4) Description of Container:

Spec 198-150 wooden box

Four I/2 in. steel bands with crimped cilip fasteners are used

$1 / 4$ in. plywood, minimum of 5 ply with opproximotely $3 / 4$ in, $x 2$ in. cleats - nailed closure

5) Specifications and Restrictions:

- Net Weight - Ápproximately $30 \mathrm{lb}$

- Authorized Gross Weight - $150 \mathrm{lb}$

- Material must be securely positioned within the box

- Not authorized for oir transport unless sealed inner contoiner, copoble of meeting reduced pressure criteria is used.

- Inner containment required copoble of withstanding penetration test (CFR49 173.398 (b) (3) (iv)) or use of suitable packaging materials to protect inner containment is required (See item $6(h))$.

6) Test Results:

\section{Environmental Conditions}

Test

Results

Discussion and/or Reference

a) Heot, $+130^{\circ} \mathrm{F}$

Poss

Engineering Analysis (EA) - Temperature is within normal operoting range for materials of construction.

b) Coid, $-40^{\circ} \mathrm{F} \quad$ Poss

$E A$ - Tempercture is within normal operating range for materials of construction. 
TABLE 4-31

(CONT.)

$\begin{array}{lll}\text { cest } & \text { Results } & \begin{array}{l}\text { Discussion and/or Reference } \\ \text { c) Reduced Pressure }\end{array} \\ \begin{array}{l}\text { Not } \\ \text { Tested }\end{array} & \begin{array}{l}\text { Packaging expected to "breathe" there- } \\ \text { fore, restricted from air transport unless } \\ \text { certain provisions made - See item } 5 .\end{array} \\ \text { d) Vibrotion } & \text { Pass } & \begin{array}{l}\text { Containers have withstood years of } \\ \text { tronsport with no occurrences of signifi- } \\ \text { cont damage due to normal vibration. }\end{array}\end{array}$

\section{Test Conditions}

2) Water Sproy Not CFR49 173.398 (b) (3) (i)

f) Free Drop (4 ft.) Pass "Impact Tests on 20-inch Cube Bird Cage - Type Tronsport Containers," LA-3203. MS, H. Noyes.

g) Corner Drop Pass "Impact Tests on 20-inch Cube Bird Cage - Type Transport Containers," LA-3203MS, H. Noyes.

h) Penetration Results Penetration of the 1/4 in. ply wood is Need expected bosed on tests on similar Qualifi- pockagings tested using 1/4 in. plywood. cotion "19B-150 Wooden box," Technical Support Document - Type A Study, MLM2229 (1975). Therefore, suitable inside packoging, capoble of withstonding the penetrotion test or suitable materiols to protect the inner pockoging must be used.

i) Compression Pass EA-Similor packaging passed compression test with $2100 \mathrm{lb}$. "19B- 150 Wooden Box," Technical Support Document Type A Study, MLM-2229(1975). 


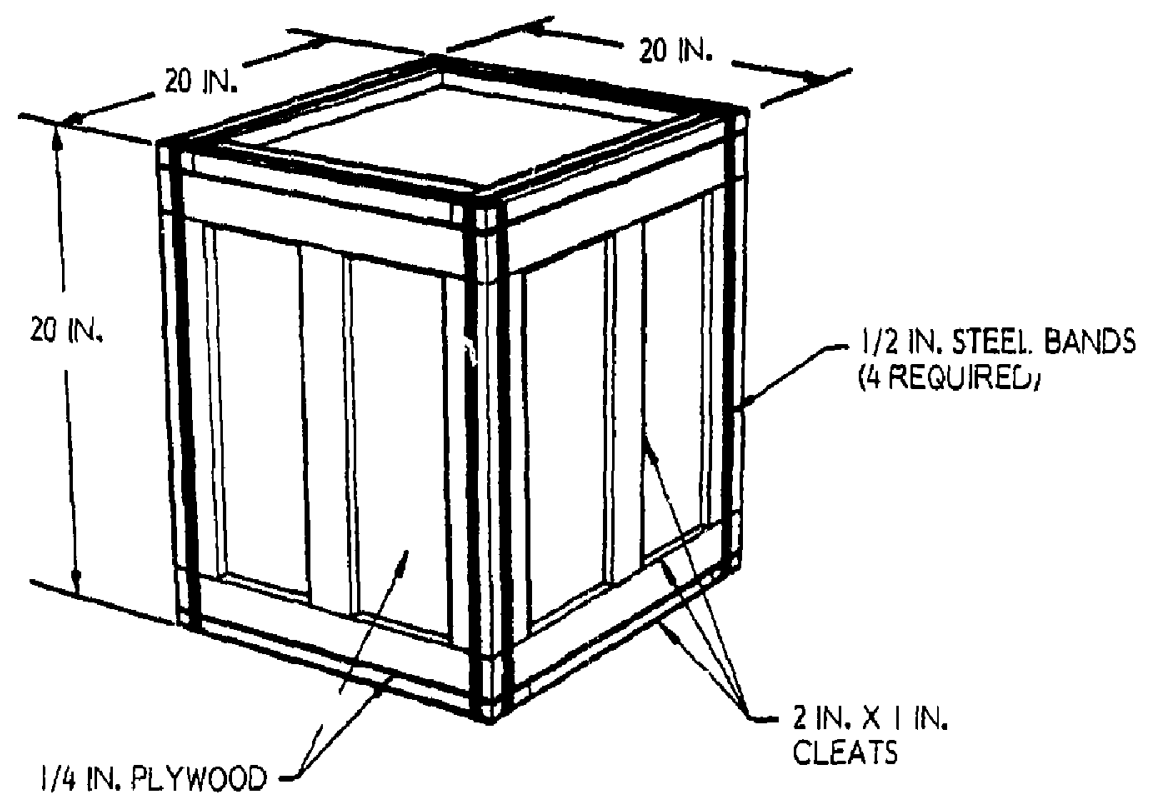

FIGURE 4-33

DOT SPECIFICATION 198-150 WOODEN BOX

(CFR49 178.191) 
TABLE $4-32$

\section{DOT SPECIFICATION 198.150 WOODEN BOX}

1) Common Name of Contoiner:

Spec 198 - 150 Wooden Box - Corner post construction

2) Authorized Contents:

Type "A" quantities of solid radiooctive material in normal or special form

3) Dimensions: *

Box sizes fested and determined to meet Spec 7A uriteria:

$\begin{array}{rrrr}\text { Width } & \text { Height } & \text { Length } \\ 12 \mathrm{in.} & 12 \mathrm{in.} & 12 \mathrm{in.} \\ 24 \mathrm{in.} & 24 \mathrm{in.} & 24 \mathrm{in.} \\ 8 \mathrm{in.} & 8 \mathrm{in.} & 32 \mathrm{in.} \\ 12 \mathrm{in.} & 12 \mathrm{in.} & 24 \mathrm{in.}\end{array}$

4) Description of Container:

Spec $19 B$ wooden box with corner post construction

Top, bottom and sides $=3 / 4$ in. A/C exterior grade plywood

Nailed closure

Corner posts -2 in. $\times 4$ in. No. I construction

5) Specifications and Restrictions:

- Authorized gross weight - $150 \mathrm{lb}$

- Any bulky equipment with sharp corners, protrusions, etc., must be securely positioned within box

- Not authorized for air transport unless seoled inner container, copoble of meeting reduced pressure criterio is used

6) Test Resulys:

\section{Environmental Conditions}
Test
Results
Discussion and/or Reference

a) Heat, $+130^{\circ} \mathrm{F}$

Pass

Engineering Anolysis (EA) - Temperature is within normal operating range for materials of construction.

* Given dimensions are for container exterior.

* The 12 in. $\times 12$ in. $\times 12$ in. size passed the $4 \mathrm{ft}$ drop test without seari.3 opening, only after $1 / 2$ in. steel bands were applied, one on each edge. 
TABLE 4-32

(CONT.)
Test
Results
Discussion and /or reference
b) Cold, $-40^{\circ} \mathrm{F}$
Pass
EA - Temperoture is within normal operating range for materials of con- struction.
c) Reduced Pressure $\quad \begin{aligned} & \text { Not } \\ & \text { Tested }\end{aligned}$
Pockoging expected to "breothe," there- fore, restricted from air transport unless certain provisions mode - See item 5 .
d) Vibrotion
Poss
Contginers hove withstood years of transport with no occurrences of signifi- cant damage due to normal vibrotion.

\section{Test Conditions}

e) Woter Sproy

Not

CFR49 173.398 (b) (3) (i)

Required

f) Free Drop (4ft.) Poss

All configurotions tested with $150 \mathrm{lb}$. "Spec 198-150 Wooden Box - Corner Post Construction," Technical Support Document - Type A Study, MLM-2229 (1975).

g) Corner Drop Pass

All configurotions tested with $150 \mathrm{lb}$. "Spec 198-150 Wooden Box - Corner Post Construction," Technical Support Document - Type A SFudy, MLM-2229 (1975).

h) Penetration Pass

"Spec 19日-150 Wooden Box - Corner Post Construction," Technical Support Document - Type A Study, MLM-2229 (1975).

i) Compression Poss

"Spec 198-150 Wooden Box - Corner Post Construction," Technicol Support Document - Type A Study, MLM-2229 (T975).

7) For Additional Information Contoct:

D. A. Edling

Monsanto Research Corporation

Mound Laboratory

P. O. Box 32

Miamisburg, Ohio 45342 


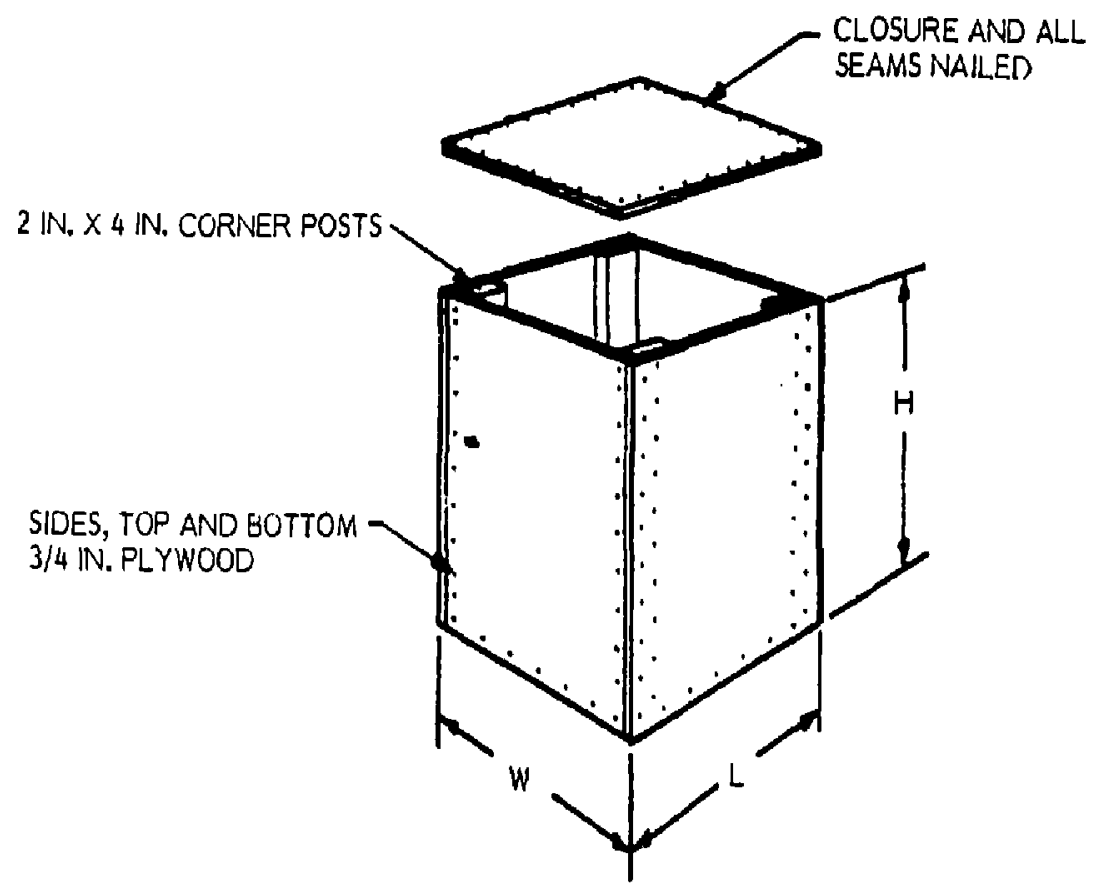

FIGURE 4-34

DOT SPECIFICATION 19B-150 WOODEN BOX

(CFR49 178.191) 
DOT SPECIFICATION I9B-75 WOODEN BOX

1) Common Name of Contuiner:

Spec 198-75 Wooden Box

2) Authorized Contents:

Type "A" quantities of solid radiooctive material in normal or special form

3) Dimensions:

Exterior -9 in. wice $\times 9$ in. high $\times 55$ in. long

4) Description of Container:

Spec 198-75 wooden box

Walls, top, bottom and ends of 1/2 in. plywood

All surfaces fully cleated (see drawing for dimension)

All joints, except closure, noiled

Screw closure - \#10 FHS

5) Specificotions and Restrictions:

- Authorized gross weight - $75 \mathrm{lb}$

- Any bulky equipment with shorp corners, protrusions, etc., must be securely positioned within drum

- Not outhorized for oir transporf unless sealed inner contoiner capable of meeting reduced pressure criterio is used

6) Test Results:

\section{Environmental Conditions}

$\begin{array}{lll}\text { dest Heat, }+130^{\circ} \mathrm{F} & \text { Rass } & \begin{array}{l}\text { Discussion and/or Reference } \\ \text { Engineering Analysis (EA) - Temperature } \\ \text { is within normol operating range for } \\ \text { matet ials of construction. }\end{array} \\ \text { b) Cold, }-40^{\circ} \mathrm{F} & \text { Pass } & \begin{array}{l}\text { EA - Temperature is within normal } \\ \text { operating range for materials of can- } \\ \text { struction. }\end{array} \\ \text { c) Reduced Pressure } & \begin{array}{l}\text { Not } \\ \text { Tested }\end{array} & \begin{array}{l}\text { Packaging expected to "breathe," there- } \\ \text { fore, restricted from air transport unless } \\ \text { certain provisions made. See item } 5 .\end{array}\end{array}$


TABLEE 4-33

(CONT.)
Test Results Discussion and/or Reference
d) Vibration
Pass
Containers have withstood years of transport with no occurrences of signifi- cont damage due to normal vibration.

\section{Test Conditions}

e) Woter Sproy

Not

CFR49 173.398 (b) (3) (i)

Required

f) Free Drop (4ft.) Pass

Tested with gross weight of $75 \mathrm{lb}$. "Spec 198-75 Wooden Box," Technical Support Document - Type A Study, MLM-2229 (1975).

g) Corner Drop

Poss

Tested with gross weight of $75 \mathrm{lb}$. "Spec 198-75 Wooden Box," Technical Support Document - Type A Study, MLM-2229 (1975).

h) Penetration

Poss

"Spec 198-75 Wooden Box," Technical Support Document - Type A Study, MLM-2229(1975).

i) Compression

Poss

Tested with weight of $1000 \mathrm{lb}$. "Spec 198-75 Wooden Box," Tectinical Support Document - Type A Study, MLM-2229 (1975).

7) For Additional Information Contact:

D. A. Edling

Monsonto Research Corporotion

Mound Loboratory

P. 0. Box 32

Miomisburg, Ohio 45342
A. W. DelMerschmar, Manager Sofeguords \& Matericls Monagement Hanford Engineering Develop. Lab. P. $0.80 \times 1970$

Richland, Woshington 99352 


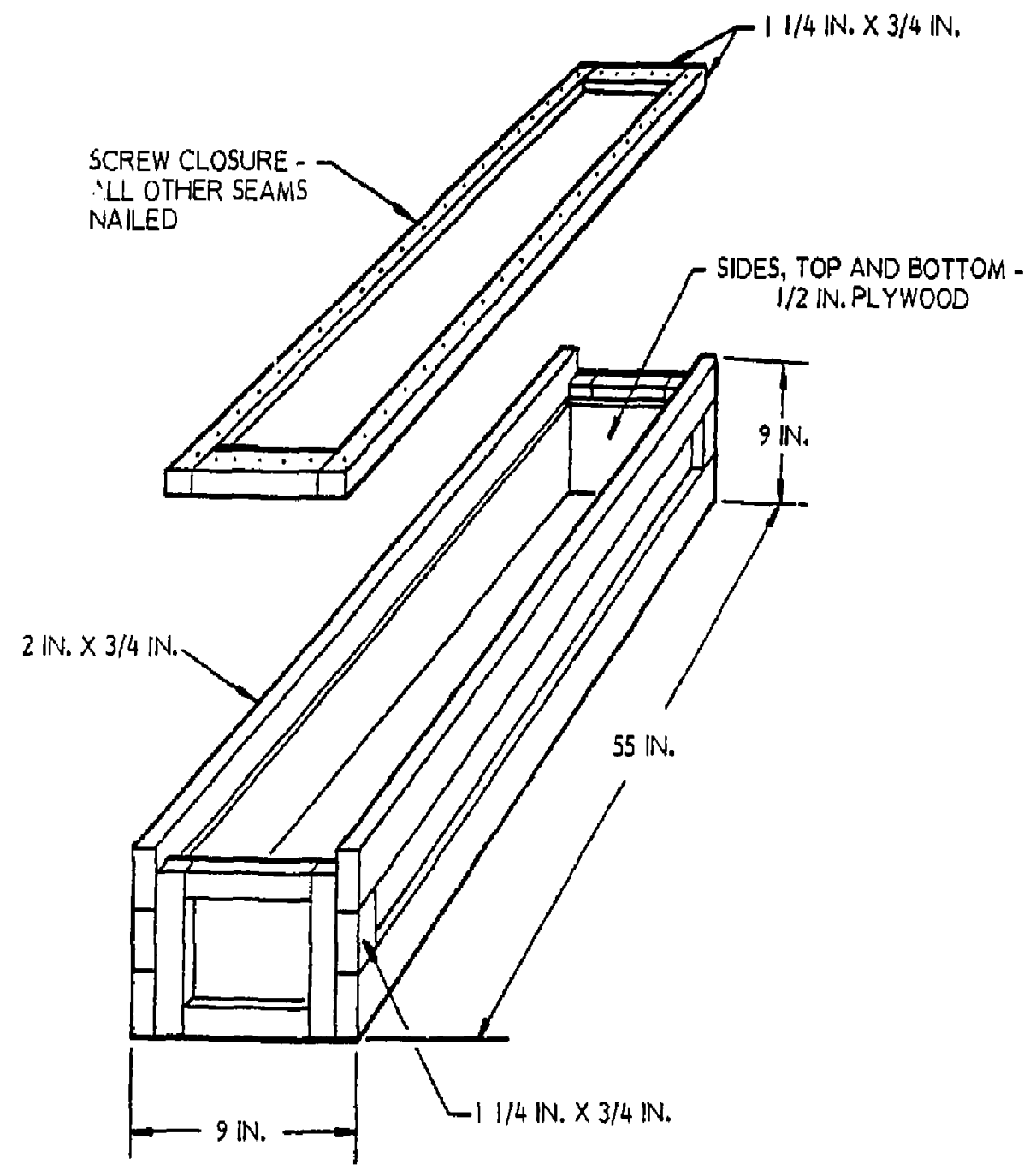

FIGURE 4-35

DOT SPECIFICATION 198-75 WOODEN BOX

(CFR49 178.191) 
TABLE 4-34

\section{DOT SPECIFICATION 2IC FIBERBOARD DRUM}

\section{1) Common Name of Contoiner:}

Spec $21 \mathrm{C}$ Fiberboord Drums

2) Authorized Contents:

Type "A" quantities of solid rodioactive materials in normal or special form. Not powders, ores, materials with significant reodily dispersible contaminotion, etc., unless contained in inner packaging capable of withstonding the penetration test CFR 49173.398 (b) (3) (iv) or unless suitable pockaging materials are used to protect the inner contrinment. (See item $6(h)$ ).

3) Dimensions:

See sketches for this information.

4) Description of Container:

Configuration 1 - 20 gollon fiberboard drum with fiberboard teieFiberpack* scoping lid

- Sidewall strength - $700 \mathrm{lb**}$

- Top - fiberboord, 0.12 in., strength $800 \mathrm{lb}$

- Bottom - fiber, thickness - 0.120 in.; strength $800 \mathrm{lb} * *$

Configurotion 2 - 15 gallon fiberboord drum with steel top and lever Leverpok* ring seal

- Sidewall strength - $600 \mathrm{lb**}$

- Top - steel, 28 gauge min.

- Bottom - fiber, thickness - 0.120 in.; strength $800 \mathrm{lb}^{* *}$

Configuration 3 - 15 gallon fiberboard drum with steel top and lever Leverpak/ ring seal

Weatherpak* - Sidewall strength - $600 \mathrm{lb} * *$

- Top - steel, 28 gauge minimum

- Bottom - fiber, thickness - 0.120 in.; strength 800 lb**

Configuration 4 - 30 gallon fiberboord drum with steel top and lever Leverpak* ring seal

- Sidewall strength - $800 \mathrm{lb**}$

- Top - steel, 26 gouge minimum

- Bottom - fiber, thickness - 0.160 in.; strength $1100 \mathrm{lb} * *$

\footnotetext{
* Trade name of Continental Con Compeny

* Mullen or Cady Test
} 
TABLE 4-34

(CONT.)

Configuration 5 - 30 gallon fiberboard drum with steef top and lever Leverpak/ ring seal

Weotherpok* - Sidewall strength $-800 \mathrm{lb}$

- Top - steel, 26 gauge minimum

- Bottom - fiber, thickness - 0.160 in.; strength $1100 \mathrm{lb} * *$

Configuration 6 - 55 gallon fiberboard drum with steel top and lever Leverpak/ ring seal

Weatherpak* - Sidewoll strength - $1000 \mathrm{lb}^{* *}$

- Top - steel, 24 gauge minimum

- Bottom - if fiber, thickness - 0.220 in.; strength $1200 \mathrm{lb}^{* *}$

5) Specifications and Restrictions:

- Authorized Gross Weight(s) - Configuration I - $115 \mathrm{lb}$ Configuration 2 - $60 \mathrm{lb}$

Canfiguration 3 - $60 \mathrm{lb}$

Configuration $4-115 \mathrm{lb}$

Configuration $5-115 \mathrm{lb}$

Configuration $6-400 \mathrm{lb}$

- Any bulky equipment with sharp corners, protrusions, etc., must be securely positioned within drums.

- All configurations - Not outhorized for air transport unless inner containment used capable of withstanding reduced pressure test CFR49 173.398 (b) (2) (iii).

- All configurations require inner containment capable of withstonding the penetration test (CFR49 173.398 (b) (3) (iv)) or use of suitable pockoging materials to protect the inner containment. This restriction is added because the penetrotion test results did not prove conclusively that the fiberboard side wolls and bottoms of the drums tested would consistently resist penetration. In oll cases, the metol tops passed the penetration test.

6) Test Results:

\section{Environmental Conditions}
Test
Results
Discussion and/or Reference
a) Heat, $+130^{\circ} \mathrm{F}$
Pass
Engineering Analysis (EA) - Temperature is within normol operating ronge for materials of construction.

* Trade name of Continental Can Company

** Mullen or Cody Test 
TABLE 4-34

(CONT.)
Test
Results
Discussion and/or Reference
b) Cold, $-40^{\circ} \mathrm{F}$
Poss
$E A$ - Temperature is within normal operating range for materials of con- struction.
c) Reduced Pressure Not
Packaging expected to "breathe," there- Tested fore, restricted from air transport unless certoin provisions mode. See item 5.
d) Vibrotion
POSS
EA - Contoiners hove withstood yeors of tronsport with no occurrence of signifi- cont damage due to normal vibration.

\section{Test Conditions}

e) Woter Spray

Not

CFR49 173.398 (b) (3) (i)

Required

f) Free Drop (4 ft.) Poss

"Spec 2IC Fiberboard Drums," Technical Support Document - Type A Study, MLM-2229 (1975).

g) Corner Drop

Pass

Corner drop completed on all pockages to authorize them for use af less thon 110 lb. "Spec 2IC Fiberboard Orums," Techilical Support Document - Type A Study, MLM-2225 (1975).

h) Penętrotion

Results

Need

Altiough a great mojority of the conQualifi- the side, some of the test results were cation not consistent, hence, the restriction given in item 5 . All metal tops passed the penetration fest.

i) Compression Poss Tested with five times the authorized gross weight. "Spec 21C Fiberboard Drums," Technical Support Document Type A Study, MLM-2229 (1975). 


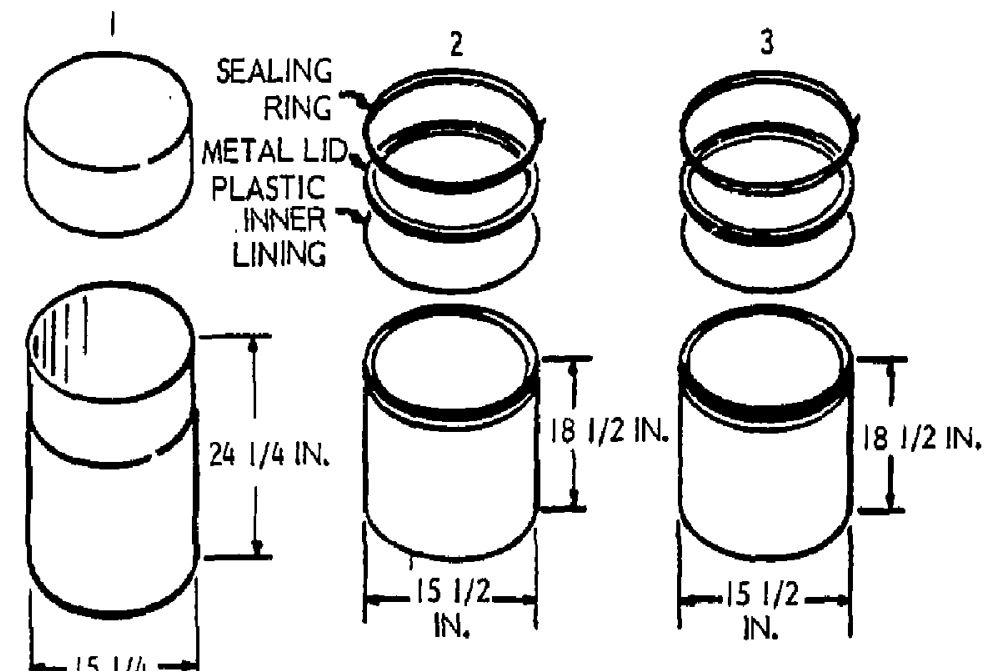
IN.
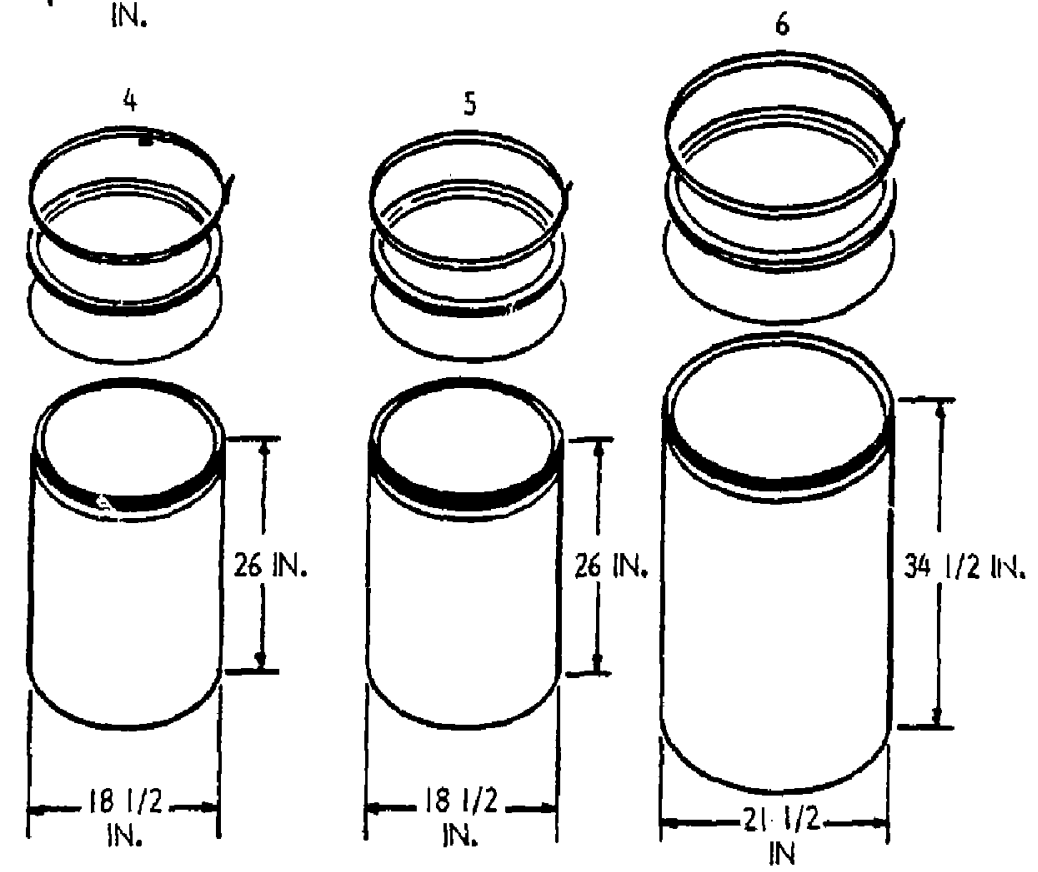

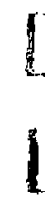

FIGURE 436

DOT SPECIFICATION 2IC FIBERBOARD DRUMS (CFR49 178.224) 


\section{DOT SPECIFICATION 42B 35-GALLON ALUMINUM DRUM}

1) Common Name of Container:

5pec 42B 35-Gollon Aluminum Drum

2) Authorized Contents:

Type "A" quantities of radioactive material as liquids* or solids in normal or special form

3) Dimensions:

See drawings

4) Description of Contoiner:

Spec 42B aluminum drum, 55 gollon

Stroight side or bilge configurotion authorized

5) Specifications and Restrictions:

- Authorized Gross Weight - $550 \mathrm{lb}$

- For shipments of tritioted heavy water, temperotures of $45^{\circ} \mathrm{F}$ or above must be maintained

- See note below for odditional requirements for shipping liquids.*

6) Test Results:

\section{Environmental Conditions}

Test Results Discussion and/or Reference

a) Hent, $+130^{\circ} \mathrm{F} \quad$ Pass

Engineering Analysis (EA) - Temperature is within normal operating range for moterials of construction. Note that for liquids other than tritiated heovy water, prior to shipping, an individuol anolysis must be mode concerning pressure buildup, compotibility etc. for that particular shipment to assure regulatory compliance.

* The 42B, 55-gallon drum passed the $30 \mathrm{ft}$ drop test; however, the CFR49 173.393 (g) (2) or (3) still requires that (2) "Enough absorbent material must be provided to absorb at least twice the volume of the radiocctive liquid contents..., or (3) A' secondary leak-resistant and corrosion-resistant containment vessel must be provided to retain the radiocctive contents under normal conditions of transport... 173.398 (b), assuming the foilure of the inner primary containment vessel." 


\section{TABLE 4-35}

(CONT.)
Test
Results
Discussion and/or Reference
b) Cold, $-40^{\circ} \mathrm{F}$
Pass
c) Reduced Pressure
Poss
$E A$ - Temperature is within normal operating range for materials of con- struction. See item 5 regarding contents.
"Safety Summory Report, Tritiated Heavy Water shipments - Under special conditions Final Report," R. A. Scoggs, February 1971, DPSPU 71-124-2, page 18.
d) Vibration
Poss
$E A$ - Containers hove withstrod years of transport with no occurrence of signifi- callif domage due to normal vibration.

\section{Test Conditions}
e) Water Spray
Not
CFR49 173.398 (b) (3) (i)
Required
f) Free Drop (4 ft.) Pass
DPSPU $71-124-2$, page 18
g) Corner Drop
Not
Required
As long as package is Fissile Class I or
h) Penetration
Pass exempt. CFR49 173.398 (b) (3) (iii).
i) Compression
Pass
DPSPU 71-124-2, page 18
DPSPU 71-124-2, page 18

7) For Additional Information Contact:

D. A. Edling

Monsanto Research Corporation

Mound Laboratory

P. 0. Box 32

Miamisburg, Ohio 45342
G. H. Hair

704- Building

Sovannah River Plant

Aiken, South Corolino 29801 


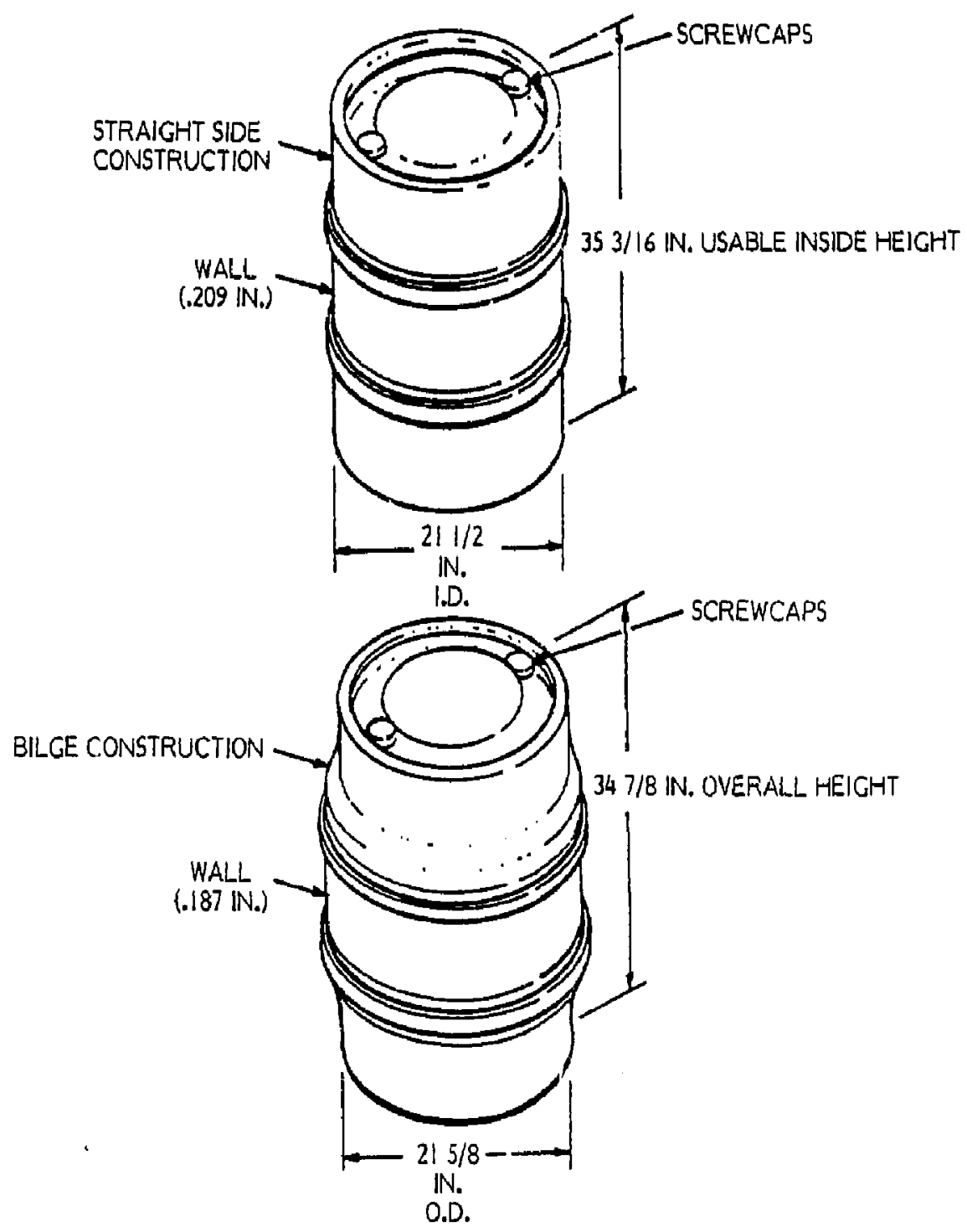

FIGURE 4-37

DOT SPECIFICATION 428 ALUMINUM DRUM

(CFR $4 \% 178.107$ ) - 55 gallon (208-L) 
It is important to note that many other disposal containers have been utilized in the 1950-1960 time period for TRU contaminated waste. Retrieval studies and progroms indicate that steel containers, wood boxes, cardboard and fiberboard boxes and other miscellaneous containers have typically failed in shallow land burial grounds at DOE facilities evaluated. 46,47 


\subsection{TRU CONTAMINATED WASTE CONTAINER CRITERIA}

The purpose of this section is to briefly review postulate criteria for TRU waste containers.

\section{5.) WASTE ISOLATION PILOT \\ PLANT (WIPP) WASTE-ACCEPTANCE CRITERIA $39,40,58$}

Appendix C, Sections 2.0 and 3.0 present the preliminary waste-acceptance criteria for the WIPP focility. These criterio include the July I, 1977 version (Section 2.0) and the updated version utilized in the Draft EIS for WIPP (Section 3.0) The criterio are established based upon a DOE steering committee mode up of waste generators and organizations responsible for WPP. The criteria recognize two levels of TRU waste: contact-handled and remotely-handled (established by surface radiation dose of the waste containers); and they address combustibility, gos generation, immobilization, explosives, pyrophorics, and hozardous materials os they impact the waste form. The waste containers have - 10 year design life requirement to allow retrievability and are required to be DOT Type A structures. The waste pockoge criterio establish design limits for waste package, structure, handling, weight, dimensions, thermol power, criticality and radiation surface-dose rate and contaminction level. Tables 5-1 through 5-3 present the design woste containers anticipated at WIPP. ${ }^{39}$ Additional information developed by the Office of Waste Isolation on various TRU Waste forms and contoiner types is also included in Appendix C, Secrion 4.0.

\subsection{STANDARD CONTAINERS FOR INEL TRU WASTE ${ }^{40,39}$}

Standardized containers are used at the INEL Radioactive Waste Mariagement Complex. These containers are designed to provide safety, integrity, and improved space utilization of the RWilC. The following containers are approved by the Department of Transportation (DOT) and by DOE-Idaho for use of INEL.

(1) The DOT 17C 55-gollon (208-liter) drum, per procurements specificotion, is a standard steel drum, constructed of 16-gauge moterials, with o removable heod. 


\section{TABLE 5-1}

DEFENSE CONTACT-HANDLED TRU WASTE (DRUM) $)^{39}$

\section{Remarks}

Type of container

Lins

(if usad)

Weir it of container

Surfoce-

dose rate

Surface contominotion

Waste properties
DOT-17C 55-gallon (208-liter) steel drum

0.09 -in $(2.3 \mathrm{~mm})$ thick, rigidpolyethylene inner liners

$640 \mathrm{lb}(290 \mathrm{~kg})$

$\leq 200 \mathrm{mrem} / \mathrm{hr}$

Limits in 49 CFR 173.397

Combustible: paper, cordboard boxes, wooden boxes, plost ic bags, rubber scrap, rags, surgical gloves, clothing, etc.

Noncombustible: residues or solutions from chemical processing, building rubble, metal, glossware, sludges, and acids
Rocky Flats Plant Stondard SX-200

Rocky Flats Plant Stondord SX-202

Interim wasteacceptance criterion

Interim wasteacceptance criterion

\section{Padionctive \\ isotope}

\section{Pu-238}

Pu-239

Pu-240

Pu-24l (beta emitter)

Am-24!

TOTAL

Totol fissile content

Total Pu
Expected activity

(Ci/drum)

4. $1-2^{*}$

4.8.1

$1.2-1$

2.9

7.8-3

3.5

$7.8 \mathrm{~g}$

$8 \mathrm{~g}$
Surfoce contominotion (Ci/drum)

1.28-8

$1.49-7$

3.63-8

2.00-6

2.45-9

$2.20-6$

${ }^{*} 4.1-2=4.1 \times 1 x^{-2}$. 
TABLE 5-2

DEFENSE CONTACT-HANDLED TRU WASTE $(B O X)^{39}$

\section{Remarks}

\begin{tabular}{|c|c|}
\hline $\begin{array}{l}\text { Type of } \\
\text { contoiner }\end{array}$ & $\begin{array}{l}\text { DOT-7A } 4 \times 4 \times 7-f t(1.2 \mathrm{~m} \times 1.2 \mathrm{~m} \\
\times 2.1 \mathrm{~m}) \text { plywood box }\end{array}$ \\
\hline $\begin{array}{l}\text { Weight of } \\
\text { contoiner }\end{array}$ & $\begin{array}{l}\text { Moximum } 10,000 \mathrm{lb}(4,500 \mathrm{~kg}) \text {; } \\
\text { typical } 3,000 \mathrm{lb}(1,360 \mathrm{~kg})\end{array}$ \\
\hline $\begin{array}{l}\text { Surfoce- } \\
\text { dose rote }\end{array}$ & $\leq 200 \mathrm{mrem} / \mathrm{hr}$ \\
\hline $\begin{array}{l}\text { Surface } \\
\text { contamination }\end{array}$ & Limits in 49 CFR 173.397 \\
\hline $\begin{array}{l}\text { Waste } \\
\text { properties }\end{array}$ & $\begin{array}{l}\text { Combust ible: poper, cardboord } \\
\text { boxes, wooden boxes, plostic bags, } \\
\text { rubber scrap, rogs, surgical gloves, } \\
\text { clathing, etc. }\end{array}$ \\
\hline & $\begin{array}{l}\text { Noncombustible: residues or solu- } \\
\text { tions from chemical processing, } \\
\text { building rubble, metal, glassware, } \\
\text { siudges, and ocids }\end{array}$ \\
\hline
\end{tabular}

Rocky Flats Plant

Standards $5 X-211$ (plywood box) and $5 x-207$

(fibergloss-reinforcedpolyester coating)

Interim wosteocceptonce criterion Interim wosteacceptance criterion

Equipment and materials too large for 55-gallon drums

\begin{tabular}{|c|c|c|}
\hline $\begin{array}{l}\text { Radicactive } \\
\text { isotope }\end{array}$ & $\begin{array}{l}\text { Expected } \\
\text { activity } \\
\text { (Ci,box) }\end{array}$ & $\begin{array}{c}\text { Surfoce } \\
\text { contaminotion } \\
\text { (Ci/box) }\end{array}$ \\
\hline $\begin{array}{l}P u-238 \\
P u-239 \\
P u-240 \\
P u-241 \text { (beto ennitter) } \\
\text { Am-241 }\end{array}$ & $\begin{array}{l}6.5-2^{*} \\
7.5-1 \\
1.8-1 \\
4.6 \\
1.2-2\end{array}$ & $\begin{array}{l}8.66-8 \\
9.94-7 \\
2.41-7 \\
1.34-5 \\
1.63-8 \\
\end{array}$ \\
\hline TOTAL & 5.6 & $1 . \overline{47-5}$ \\
\hline Total fissile content & $12.2 \mathrm{~g}$ & \\
\hline Total Pu & 139 & \\
\hline
\end{tabular}

* $6.5-2=6.5 \times 10^{-2}$ 
TABLE 5-3

DEFENSE RENOTEL Y HANDLEO TRU WASTE ${ }^{39}$

\section{Remorks}

$\begin{array}{ll}\begin{array}{l}\text { Type of } \\ \text { container }\end{array} & \begin{array}{l}\text { Steel conister (1200-liter internal } \\ \text { volume })\end{array} \\ \begin{array}{l}\text { Weight of } \\ \text { container }\end{array} & 10,000 \mathrm{lb}(4,500 \mathrm{~kg}) \\ \begin{array}{l}\text { Surfoce- } \\ \text { dose rate }\end{array} & \leq 100 \mathrm{rem} / \mathrm{hr} \\ \begin{array}{l}\text { Surface } \\ \text { contamination }\end{array} & \text { Limits in } 49 \mathrm{CFR} 173.397 \\ \begin{array}{l}\text { Waste } \\ \text { properties }\end{array} & \begin{array}{l}\text { Primarily noncombustible: concrete, } \\ \text { steel, process sludges, etc. }\end{array}\end{array}$

Proposed for WIPP reference redository

Proposed wasteocceptance criterior

Proposed wosteacceptance criterion

\begin{tabular}{lcc}
$\begin{array}{c}\text { Rodiooctive } \\
\text { isotope }\end{array}$ & $\begin{array}{c}\text { Activity } \\
\text { level } \\
\text { (Ci/conister) }\end{array}$ & $\begin{array}{c}\text { Surfoce } \\
\text { contamination } \\
\text { (Ci/conister) }\end{array}$ \\
\cline { 2 - 3 } SR-90/Y-90 & $4.2+2^{*}$ & $8.94-6$ \\
Co-60 & 2.6 & $5.59-8$ \\
Ru-10E/Rh-106 & 3.7 & $7.82-8$ \\
Cs-137/Ba-137m & 2.1 & $4.48-8$ \\
Eu-152 & $5.3-1$ & $1.12-8$ \\
Eu-154 & 2.1 & $4.48-8$ \\
Th-232 & $1.2-3$ & $1.64-10$ \\
U-234 & $9.7-6$ & $1.30-12$ \\
U-235 & $4.1-4$ & $5.51-11$ \\
U-238 & $8.9-3$ & $1.19-9$ \\
Pu-238 & $1.1-1$ & $1.40-8$ \\
Pu-239 & 1.3 & $1.69-7$ \\
Pu-240 & $3.0-1$ & $4.07-8$ \\
Pu-241 & 7.8 & $1.64-7$ \\
Am-241 & $2.1-2$ & $2.81-9$ \\
Cm-244 & 5.3 & $7.04-7$ \\
TOTAL & $4.5+2$ & $1.03-5$ \\
Total fissile content & $211.8 \mathrm{~g}$ & \\
Fissile density & $0.177 \mathrm{gil}$ & \\
& &
\end{tabular}

$4.2+2=4.2 \times 10^{2}$. 
(2) The DOT 6ivi pockoging consists of a DOT 17C 55-gollon (208. liter) drum with fiberboard ceniering media and a DOT spec $2 R$ inner containment vessel. DOT ólli pockcging is ccceptable at the INEL for storage only when the drums have no mechanism for venting. This requires the waste generator to obtain opproval for modification to the DOT 6M pockaging which may be obtained when the 6IV package is shipped inside another DOT approved transport device.

The DOT specification $2 R$, or equivolent, containment vessel must be made of stainless steel, malleable iron, bross or other moterial having equivalent strength. The vessel must have a maximum length of $65.4 \mathrm{~cm}$ and have a maximum outside vessel diameter of $12.7 \mathrm{~cm}$. Ends of the vessel must be fitted with a screw-type closure, flanges of welded or brozed plate.

(3) The DOT 1/H 1/4-liter drum is a standard steel drum constructed of 18 gouge material with o removable heod.

(4) Two styles of DOT 7A boxes are acceptoble

(a) The DOT 7A wooden box is an externally cleated plywood box, normally $1.2 \mathrm{~m} \times 1.2 \mathrm{~m} \times 2.1 \mathrm{~m}$.

(b) The DOT 7A wooden box, per procurement specification 57201l, is a plywood box with internal stiffeners, normally $1.2 \mathrm{~m} \times 1.2 \mathrm{~m} \times 2.1 \mathrm{~m}$.

(5) The DOT 7A steel box is a rectangular steel box of dimensions $1.28 \mathrm{~m} \times 1.48 \mathrm{~m} \times 1.84 \mathrm{~m}$. When used os an overpock it will hold eight (8) $17 \mathrm{C} 208$-ilter drums in two (2) layers of four (4) drums each or twelve (12) $17 \mathrm{M} 114$ liter druns in two (2) layers of six (6) drums each. This box does not require a security seal when it is used as an overpack, provided each of the DOT approved inner containers is properly sealed.

\subsection{MOUND TRU WASTE CONTARNER ${ }^{49,11}$}

Extensive work at the DOE Mound Facility in the area of conceptual design criteria for defense TRU waste packaging led to the following proposed criterio. 


\subsection{1}

The structural design of all low-level TRU waste containers must meet the minimum requirements of a Type A package as outlined in 49CFR173.398(b). Low-level TRU waste is any solid waste material, other than high-level waste, which is contaminated with long-lived alpha emitters to the extent that, under the provisions of DOE ivianual Chapter 0511 , it is not suitable for surfece burial; but which exhibits sufficiently low rodiation levels ( $s 500 \mathrm{mrem} / \mathrm{hr}$ ) that it is amenable to handling by "contact" methods. This minimum structurol design requirement shall apply to all TRU waste pockoges to assure sofety to personnel during handting, loading and unloading operations. During shipment, the DOT Type A containers may be placed inside a reusable DOT Type B overpack.

\section{3 .2 DESIGN LIFE (DECOMPOSITION)}

The design life of all TRU low-level waste containers for contamination-free retrieval shall be 10 yr minimum when stored in a noncorrosive atmosphere $(\mathrm{pH} 7-8)$, álo relative humidity, and $38^{\circ} \mathrm{C}$. The design life parameters racy suggest a change in DOE manual 0511 from a $20-y r$ intact contamination-free retrievability to a 10-yr intact contamination-free retrievability concept. Life of the shipping container will start from the time the container is manufactured until backfilled in the federal repository. The 10-yr life is based upon the forecast that the WIPP will be fully oparational for TRU woste containers in 1988. Life cycle of the contoiner will include manufocturing, delivery, stor...

transmittal into the WIPP, analysis and backfilling. This life cycle shoule we approximately $5 \mathrm{yr}$; however, it could approach $10 \mathrm{yr}$ becouse the backlog of interim stored wostes will be in disect competition with freshly pockoged wase for isolation space in the Isolation Focility. All filled waste containers must be protected from environmental condition: that could significontiy reduce the design life of the waste containers to less than $10 \mathrm{yr}$.

\subsubsection{MATERIALS OF CONSTRUCTION}

Consideration for materials of construction are based on design life and structural design requirements. Ferrous and nonferrous metals, fiberglass, 
plostics, reinforced plastics, fiberboard, corrugated fibers, wood, and concrete hove been considered for contoiner moteriols. All these muteriols can meet the requirements for hazardous moterials tronsportation and are ccceptable in the WIPP in limifed quantities. Therefore, the choice of materials, or combinotions thereof, con be made from the above group. However, ch :e will be influenced by the waste form, container design, economics, and, most important, final WIPP TRU Waste Acceptonce Criteria.

\subsubsection{MAXIMUM WEIGHT OF CONTAINER AND CONTENTS}

The weight of a single container filled to $98 \%$ capacity is limited to $11,400 \mathrm{~kg}$ based on a contents density of $2000 \mathrm{~kg} / \mathrm{m}^{3}$. This design weight is bosed on the 11,400 moximum copacity of the WIPP low-level hoist coge.

\section{SHAPE}

The container family should be modular, hoving a shope which will provide maximum pocking efficiency in storage. The cylindrical container has a packing efficiency of $\sim 0.69$.

\section{DIMENSIONS}

Waste container dimensions should be bosed on criteria to provide flexibility in mode of transportation.

\section{CLOSURES}

Contoiner closures should be gasketed to assure tightness under all loads imposed during handling. The closures should be designed to prevelit distortion of the joints by the imposed loads. Where personnel access to the contanner is restricted becouse of high radiation levels or other hozords, the closures should be designed for remote operation. 


\section{VENTS}

Burial contoiners should be provided with vents if there is a requirement that they be protected ogainst variotions in internal pressures until they have been placed in fincl burial location. Such vents, which should be discharged through high efficiency particulate oir (HEPA) filters, should be closed or covered before backfilling.

\section{PANITING AND COATINIG}

Sufficient area of the external surfaces of one side and the lid of the container should be pointed with o corrosion-resistant paint.

\section{INFORMATION}

The container design should include the following weight informotion: weight of container, weight of lid, maximum allowable weight of contents, gross total allowable weight. The gross weights should be pointed on the lid and side in letters no less thon three inches high.

\section{HANDLING APPURTENANCES}

All low-level TRU waste containers must be provided with cleats, offsets, or chimes which permit handling by fork lift.

\section{SECURITY SEAL}

The outside of each woste container must incorporate a feature such as a seal that is not readily breakable and that, while intact, will be evidence that the pockage has not been illicitly opened. 


\subsection{SUGGESTED WASTE FORM AND PACKAGE CRITERIA}

The coriceptuol design of facilities to accept TRU waste at the WIPP has been completed and documented in a formal report. The WIPP criteria, to the extent documented and approprinte, have been reviewed and incorporated into these suggested criterio.

\subsubsection{WASTE FORM CRITERIA}

Waste to be eventually disposed of a federal repository will meet the following waste form criterio:

(1) Combustibles and Orgonics

Combust ibles and organics will be incinerated or similarly treated and the resultant product fixed in a solid medium (matrix) prior to receipt ot the repository.

(2) Liquids

Liquids and sludges will be fixed in homogenous solids possessing low leachability in saturated solt brine or pure water.

(3) Heot Generotian

Maximum thermal power per canister will be $300 \mathrm{w}$.

(4) Free Liquids

The waste shall contain no free liquid. Free liquids are defined os those not treated to eliminate the charocteristics of fluidity, dispersibility or freedom of movement within the packoging.

(5) Pyraphoric or Explosive Materials

Pyrophoric or explosive materiols shall not be permitted unless converted to a nonreactive form before packinging.

(6) Spontaneous Combustion

Materials shall not be combined within a waste container which could lead to spontaneous combustion or production of internal container pressure through chemicol or bocterioiogical reactions. 
(7) Toxic Moterials

Highly toxic materials contaminated with TRU nuclides shall be identified. Their handling will be resolved on an individual bosis.

(8) Nuclear Sofety

Amounts of fissile materials shall be limited so an infinite array of such packages will remain subcritical based on $a$ "worst cose" analysis.

(9) Alphe Radiolysis

TRU materials shall be limited to prevent production of unacceptable quantities of alpho radiolysis products during storage. Such praducts may result in internal pressures exceeding the sealing copobilities of the container or may result in the formation of an explosive gas mixture.

\subsubsection{PACKAGE DESIGN CRITERIA}

(1) Generol

All waste shall be stcre retrievably (minimum of 25 years)* and shall be contained by of least two independent barriers throughout tronsport, hondling, and interim storoge.

(2) Container Size

All waste containers shall be small enough in volume, light enough in weight, and of uniform shape in order to be compatible with the repository design, transportation methods, and handling methods. The woste containers shall exhibit good volumetric efficiency in terms of waste containment and storage of the containers. The following criterio estoblish minima and maximg for the woste container size.

\section{(a) Container Dimensions}

To be compotible with the repository focility, contoiners shall have a minimum outside diameter that precludes two or more containers from wedging in the disposal vault. The container's outside diameter must, therefore, be greoter than one-half the inside diameter of the storage vault to be utilized. The maximum outside diameter of the container will be approximately $51 \mathrm{~mm}$ (2 in.) less than the inside

\footnotetext{
* This sriterion is more stringent than present DOE criteria indicated in Section 5.3.2. Resolution of this and other differences should be bosed upon additional analysis and review.
} 
diameter of the storage vaults. The mroximum length of a waste container shall be such that the container will fit in a retrievable storage vault and still allow space for a shield plug if necessary.

The woste will be packaged in canisters $0.61 \mathrm{~m}(2 \mathrm{ft})$ in diameter $\times 4.6 \mathrm{~m}$ ( $15 \mathrm{ft}$ ) long or a similar size. Domoged canisters received will be placed in overpack containers $0.66 \mathrm{~m}$ (26 in.) in diameter $\times 4.9 \mathrm{~m}$ $(16 \mathrm{ft})$ long. These volues are token from the WIPP design ana are arbitrary relative to regulatory impact.

(b) Container Weight (looded)

The weight allowable for a loaded woste container is decendent on the hondling method used for placement and retrieval of the container in the disposal voult. The WIPP design criteria estobiish a moximum weight per canister of $4,550 \mathrm{~kg}$ and 5,050 $\mathrm{kg}$ with overpack. These values are taken from the WIPP design and ore arbitrory relative to regulatory impoct.

(c) Container Shape

All waste containers stored at the repository in shielded oreas shall be right circulor cylinders. In addition, there shall be no sharp, pointed edges on the waste contoiner that could couse difficulty during plocement of the waste in the vaults.

Wostes stored in non-shielded oreas may have other physical configurations subject to restrictions by tronsporation criteria and the repository design.

(d) Large ltems

Large process vessels, piping, concrete, etc., will be reauced in size to fit into the containers defined ouove. Where the size, weight, and contamination are appropriate, the object may be welded shut to form its own container.

\section{(3) Container Strength}

The woste container shall have sufficient strength to withstand stacking in the storage vault to a maximum height allowed by the design. 


\section{(4) Container Closure}

Each container shall be sealed by the waste generotor with a numbered seal so as to preclude removal of the lid without destroying the seal.

\section{(5) Corrosion Protection}

Waste package surfaces constructed from moterials subject to corrosion shall be cooted with corrosion inhibitors or otherwise protected. 


\subsection{REFERENCES}

I. National Academy of Sciences, National Research Council, Commission on Natural Resources, Committee on Rodiocctive Waste Monagrement, Panel on Land Burial 1976. The Shollow Lond Burial of Low-Level Rodiooctively Contaminoted Solid Waste, Woshington, D. C.

2. Battelle Northwest Laboratory, "Transuronium Radionuclides--A Manul of Good Practice," BNWL-SA-3075, January 1970.

3. U. S. Atomic Energy Commission, 1974, Environmental Survey of the Uranium Fuel Cycle, WASH- 1284, April, T974.

4. Colombo, P., and Neilson, R. M., 1976, "Critical Review of the Properties of Solidified Rodionctive Waste Packages Generoted at Nucleor Power Reactors," BNL-NUREG-50591, December, 1976.

5. TERA Advanced jervices Corporation, "liventory and Sources of Transuranic Solid Wastes," prepared for Lowrence Livermore Loboratory, Revision 1, May 1979.

6. DOE Manual Chapter 05:i, "Radioactive Waste Manogement," DOEM-0511-01, September $19,1973$.

7. TERA Advanced Services Corporation, "Transuranic Contaminated Waste Functional Definition and Implementation" prepared for Lowrence Livermore Laboratory, June, 1979.

8. Los Alamos Scientific Laboratory, "Guidelines for the Interim Storages of AEC-Generoted Solid Transuranic Wastes," LA-5645, June 1974.

9. U. S. Department of Energy, "Report of Task Force for Review of Nuclear Waste Management," Draft DOE/ER-0004, February 1978.

10. U. S. Energy Research and Development Administration, 1976, Alternotives for Managing Wastes from Reactors and Post-Fission Operation in the [WR Fuel Cycles, ERDA 76-43, Vols. 1-5, May 1976.

11. Doty, J. W., and Peterson, J.8. "Acceptable TRU Pockaging for Interim Storage and/or Terminal isolation: FY 1977 Final Report," MLM-2489, Februory 17, 1978.

12. Jumps, J. J., "Current Practices for Dispasal of Solid Low-Level Radioactive Woste," Radioactive Waste from the Nuclear Fuel Cycles, AIChE Symposium Series $\sqrt{0.154, \text { Vol. } 12 ., 1976 .}$

13. U. 5. Atomic Energy Commission, Division of Reactor Developmert and Technology, "Land Burial of Solid Radiooctive Wastes: Study if Commercial Operations and Facilities," WASH 1/43, Washington, D. C. 1968 . 
14. Battelle Pacific Northwest Laboratories, "High-Level Radioactive Woste Management Alternatives," BNWL-1900, Vols. 1-4, Richland, Washington, May 1974.

15. U. S. Environmental Protection Agency, "Criteria for Radioactive Wastes," Federal Register, Vol. 43, No. 221, November 15, 1978.

16. Smyrl, W. B., et al, "Behovior of Condidate Canister Materials in Deep Ocean Environments," Paper No. 85 presented at the Annual NACE Meeting, San Francisco, Colifornia, March 1977.

17. Slate, S. C., "Corrosion Experience in Nuclear Waste Processing at BattelieNorthwest," Poper 81 presented of the NACE Meeting, San Froncisco, Colifornio, March 1977.

18. Angerman, C. L., and Rankin, W. N., "Durability of Containers for Storing Solidified Radioactive Wastes," Materials Performance 17 (4), April, 1978.

19. MocMillan, N. H.y and Roy, R., "Corrosion of Metals in o Hot, High Pressure Brine Environment," Poper AF4 published in the proceedings of "Symposium on Science Underlying Rodioactive Waste Manogement," Materials Research Society, Boston, Massachusetts, November, 1979.

20. Mattsson, E., "Corrosion Resistance of Canisters for Find Disposal of Nuclear Fuel," Poper AF2 presentef at and published in the proce of the "Symposium on Science Underlying Radionctive Waste M: ment," Materials Research Society, Boston, Mossachusetts, 1978.

21. Colombo, P., and Neilson, R. M., "Properties of Radiooctive Wastes and Waste Containers" BNL-NUREG-50774 (Progress Report 6), Janvary, 1978.

22. Godbee, H.W., and J. P. Nichols, "Sources of Transuranium Solid Waste and Their Influence on the Proposed National Radiactive Wostie Repasitory," ORNL-TM-3277, January 1971.

23. U. S. Atomic Energy Commission, Draft Environmental Stotement--Management of Commercial High-Level and Transuranium Contaminated Radioactive Woste, WASH-1539, September 1974.

24. Braithwaite, J. W. and Molecke, M. A., "High-Level Waste Conister Corrosion Studies Pertinent to Geologic Isolction" NUREG-CP-005, Proceedings of the Conference on High-Level Radioactive Solid Waste Forms, December 19-21, 1978, Denver, Colorado.

25. U. S. Nuclear Regulatory Commission, "A System for Clossifying Radianctive Waste Disposal-What Woste Goes Where?" NUREG-0456, June 1978.

26. Handbook of Chemistry and Physics, Chemical Rubber Company, Cleveland, Ohio, 1969. 
27. Rankin, W. N., "Compotibility Testing of Vitrified Waste Forms," Paper presented at Corrosion 78, NACE, Houston, Texas, March 6-10, 1978.

28. Lawrence Livermore Laboratory, "A Review of Methods for the Detection of $10 \mathrm{nCi} / \mathrm{g}$ of Transuronic Isotopes in Solid Waste," UCRL-52200, January $7,1977$.

29. Personal Communications with D. J. Kuom, Lowrence Livermore Luboratory, Memorondum of September 21, 1978 (TRU Woste Inventory).

30. Allied-General Nuclear Services, 1977: "Solid Waste Assay Facility Boseline Description" NMS-8, prepared for Sandia Laboratory.

31. Romanoff, M., Underground Corrosion, NBS Circular 579, 1957.

32. Soil Survey Monud, U. S. Department of Agriculture Handbook, No. 18, 1951.

33. Corrosion Data Survey, NACE Publication 257, 1974.

34. Booth, G. H., A. W. Cooper, and P. M. Cooper, Br. Corros. J., 2, 109, 1967.

35. Booth, G. H., A. W. Cooper, and A. K. Tiller, Br. Corros. J., 2, 115, 1967.

36. Schwerdtfeger, W. J., J. Res. Nat, Bur. Stand, 69C, 71, 1965.

37. Colombo, P., et al: "Properties of Radiooctive Wastes and Waste Contoiners," (Progress Report No. 8) BNWL-NUREG-50921, September, 1978.

38. Sandia Laboratories: "TRU Waste Form and Package Criteric Meeting," SAND 77-1178, August, 1977.

39. U. S. Department of Energ"; 1979: "Drcft Environmental Impact Statement Waste Isolation Pilot Plant," DOE/EIS-00260, Volumes I arid 2, April, 1979.

40. U.S. Department of Energy, 1979: "Environmental and Other Evaluations of Alternatives for Long-Term Management of Stored INEL Transuranic Waste," DOE/ET-0081, February, 1979.

41. U. S. Nuclear Regulatory Commission, 1977: "Final Environmental Statement on the Transportation of Rodioactive Material by Air and Other Modes," NUREG-0170, Volumes I and 2, December, 1977.

42. Western Interstate Nuclear Board, 1974: Transportation of Radioactive Materials in the Western States, March, 974.

43. Hammond, J. E.: "Design Criteria - Transuranic Dry Wast a Burial Containers (Steel and Reinforced Concrete)," ARH-CD-353, Rev, 3, September 1, 1976. 
44. Codbee, H.W.: "Spontaneous Combustion, Oxidation and Pyrolysis of Combustible solid Hoste Containing Transuranium Elements in Combustible and Nun-Combustible Containers," ORNL-4768, May, 1972.

45. Edling, D. A.: "Certification of Packagings: Compliance with DOT Specificotion 7A Packaging Requirements," NLLM-2324, October \&, 1976.

46. Card, D. H.., and Wang, D.K.: "Initial Drum Retrieval - Interim Report July, 1974, to September, 1976," TREE-1079, Moy, 1977.

47. Card, D. H.: "Early Woste Retrieval Interim Report," TREE-1047, February, 1977.

48. Metzner, J. C., and Sriyder, A. M.: "Transport, Handing and Iriterim Storage of Intermediote-Level Transuranic Wiaste at the INEL," TREE-1172, September, 1977.

49. Peterson, J. B.: "An Alternative to Stop the Proliferation of Low-Level TRU "Waste Containers," EPA 520/3-79-002, pp. 116́-120, Niay, 1979.

50. Hammond, J.E.: "Design Criteria - Burial Containers for Non-Transuranic Solid Radioactive Waste," ARH-CD-767, August II, 1976.

51. Madding, R. D., et al: "Documentation of DOT-SP-5915 for 55/30 and 83/55 Drum Combination Packaging," MLM-1911, April 28, 1972.

52. Edling, D. A., et al: "Certification of ERDA Controctors' Packaging with Respect to Compliance with DOT Specification 7A Performance Requirements. Phase II, Summary Report," MLM-2228, June, 1975.

53. Science Applications, Inc.: "Technical Support for GEIS: Radioactive Waste Isulation in Geologic Formations. Volume 2: Commercial Waste Forms, Pockoging and Projections for Preconceptuol Depository Design Studies," Y/OWI/TM-36/2, April, 1978.

54. U. 5. Atamic Energy Comınission: "Directory of Packagings for Transportotion of Radioactive Moterials," WASH-1279, October, 1973.

55. Kniazewycz, B. G., and J. E. Ash: "Is the Steel Drum the Answer?" Monogement of Low-Level Rodionctive Waste, Moy 23-27, 1977, Atlanto, Ga.

56. U. S. Nuclear Regulatory Commission: "A Radioactive Woste Disposal Classificotion System." NUREG/CR-1005, September, 1979.

57. TERA Advanced Services Corporotion: "Transuranic Contaminated Waste Form Charocterization and Data Base," prepared for Lowrence Livermore Laborotory, November, 1979.

58. U.S. Department of Commerce: Technical Support for GEIS: Rodiooctive Wasie Isolation in Ceologic Formations, Volume 2: Commercinl Woste Forms, Packaging and Projectians for Preconceptual Repository Design Studies", Science Applications, Incorporoted, Ook Ridge, Tennessee, April, 1978. 
APPENDIX A

GLOSSARY OF

TERMS AND DEFINITIONS

yes 
Actinide Series: The series of elements beginning with actinium, element No. 89 , and continuing through lowrencium, element No. 103, which together oscupy one position in the periodic toble. The series includes uranium, element $\mathrm{No} .92$, and all the mon-made transuranium elements. The group is also referred to as the "octinides."

Actlvotion: The process of moking a material radiooc rive by bombardment with neutrons, protons, or other nuclear porticles. Also colled radio-activation, The resultant radioactive materials are commonly called activation products.

Activity: A measure of the rate at which a material is emitting nuclear rodiations; usually given in terms of the number of nuclear disintegrations occurring in a given quantity of moterial over a unit of time; the stondard unit of activity is the curie (Ci).

AlphaPorticle (a): A positively charged particle emitted by certain radiooctive materials. It is made up of two neutrons and two protons; hence it is identical with the nucleus of a helium atom.

Alpho Waste: Waste material that is contaminated by radionuclides that emit alpho particles, porticularly (in this text) the transuranium elements.

Anion: A negatively charged ion.

Aquecous Phase: The liquid phase in solvent extroction which consists of dilute of nitric ocid.

Back End of the Fuel Cycle: Includes reactors, spent fuel storage, fuel reprocessing, mixed-oxide fuel fabrication, and waste management.

Befaflarticle ( $\beta$ ): An elementary particle emitted from a nucleus during radioactive decay. It has a single electrical charge and a moss equal to $1 / 1837$ that of a proton. A negotively chorged beto porticle is physically identical to the electron. If the beto particle is positively charged, it is called a positron ( $\beta+$ ).

Burial Grounds: Areas designated for storage of containers of radiooctive wastes by near-surfoce burial in geologic media.

Colcination: A process of solidifying high level liquid waste by evaporating to dryness on a granule and converting from the nitrate form to the oxide form.

Colcine: Moierial heated to a temperature below its melting point to bring obout loss of moisture and oxidation to a chemically stable form.

Cask: A container that provides shielding and contoirment for transportation of retrievable storage of solid waste. The shielding is normally steel or concrete, and the waste is contained in a canister within the cask. 
Cation: A positively charged ion.

Cermet: Ceramic-metal systems suitable for use at high temperotures. They have some of the desirable properties of both ceramics and metals, e.g., high melting point, high oxidation resistance, high thermal conductivity, and shock resistance.

Cladding Waste (hulls): Fuel rods in most nuclear reactors today are made up of fissionable materiols clad in a protective alloy sheathing that is relatively resistant to radiation and the physical and chemical conditions that prevoil in a reactor core. The spent fuel rods, ofter removal from the reactor and storage to permit radiogctive decoy of the short-lived fission products, are removed and in certain fuel cycle processing systems are chopped Up, and the residues of the fissionable materials are leached out chemically. The remaining residues, principally the new radioactivated cladding material (zirconium alloys, stainiess steel, etc.) and insoluble residues of nuclear fuel, fission products, activation products and transuranium nuclides, are left behind as cladding waste, which is a speciol category of tronsuranium radioactive woste.

Combustible: A "materiol copoble of being burned, except that if the only combustible content of a package is plastic lining or wropping used for contamination control purposes around incombustible objects or materiols, the conteris of the package as a whole may be considered noncombustible." (DOE Manual 0511--Radioac tive Waste Monagement)

A precise definition of the term "combustible" is difficult, if not impossible, to prepare. This difficulty arises becouse the combustible noture of a given moterial is dependent not only upon the form of the material but also on the conditions of ignition which must be considered. It is the intent of this definition that emphosis be placed on combustion. However, one should not ignore the long-term phenomeno of pyrolysis and thermal decompositien.

This definition of "combustibie" is applied to a material unciar the conditions existing (or possibly foreseen) in the disposal facility. Thus, extreme conditions and the method of packoging need not be included os factors in the jetermination of combustibility of the pockoge. Further, the production of flammoble gases need not be a consideration in determining combustibility of the waste material if the control of such gases can be accomplished by seporate meons. The overall intent of the definition is to consider those materials that may burn in the common sense of the word and that could lead to or add to a fire if not properly protected. The principal type of material considered as combustible should be the organics, which are composed mostly of hydrogen, carbon and oxygen. Those materiols clossed as fire-retardant, either by nature of the composition or becouse of treatment, should also be included since they will release heat and flammable gases if exposed to fire from other sources and con, therefore, add to the overall intensity of a fire.

Combustion: The rapid and self-propagoting oxidation of materials in air, with the evolution of significant quantities of heat. 
Concrete Motrix: A process to fix calcine in a monolithic form by mixing with o concrete slurry.

Contamination: The deposition of radioacivive moterial on a surfoce or the presence of fission products in a process stream

Contamination-Free: "A condition of the outer surfoces of stored containers, as determined by appropriate swipe surveys or direct radiation instrument surveys, sufficiently free of contomination so that under standard rodiotion work procedures for the site in question respiratory protection will not be required during container handling." (ERDAM 05/1-Rodioactive Woste Manogement)

Countercurrent: The apposed flow of the aqueous phose and organic phase in on extraction column.

Crib: A back-filled burial trench into which intermediate-level liquid waste is distributed through a perforated pipe.

Critical: The condition in which a material is undergoing nuclear fission at a self-sustaining rote; the critical mass of a material is the amount that will self-sustain nuclear fission when placed in an optimum arrangement in its present form.

Curie (Ci): $A$ unit of radioactivity defined of the amount of a radioactive material that has on acjivity of $3.7 \times 10^{0}$ disintegrations per second $(\mathrm{d} / \mathrm{s})$; millicurie $(\mathrm{mCi})=10^{-3}$ curie; microcuria $(\mu \mathrm{Ci})=10^{-6}$ curie; nanocurjo $(\mathrm{nCi})=19^{-9}$ curie; picocurie $(\mathrm{pCi})=10^{-12}$ curie; femtocurie $(\mathrm{fCi})=10^{-15}$ curie.

Decay: The spontaneous radioactive transformation of one nuclide into a different nuclide or into a different energy state of the same nuclide. Every decay process has a definite half-life.

Decommissioxing: The process of removing a focility or orea from operation ard decontaminating and/or disposing of it or placing it in a condition of standby with appropriate administrative and physical controls and sofeguards.

Decontamination: The selective removal of rodiooctive moterial from a surfoce or from within another material.

Deep Geolugic Formations: Geologic media beneath the continents and isolated from biologic species and phenomenc. Distinguished from ice sheets and seo floor geologic media.

Defense Waste: Nuclear waste generated from government defense programs as opposed to cormerciol woste which is generoted from civilion reoctor programs.

Denitration: The chemical process of converting uranyl nitrotes $\mathrm{NO}_{2}\left(\mathrm{NO}_{3}\right)_{2}$ $\left.6 \mathrm{H}_{2} \mathrm{O}\right)$ to uranium trioxide $\left(\mathrm{UO}_{3}\right)$. 
Diluent: An organic compound used to dilute the solvent in a solvent extraction process. It is usually nonreacting.

Disposalf The planned releose or plocement of waste in o manner that precludes recovery,

Dose: The energy imported to matter by ionizing rodiation per unit mass or irrodiated material at a specific location. The unit of absorbed dose is the rad.

Engineered Storoge: The storage of rodioactive wastes, usually in suitable sealed containers, into any of a variety of structures especially designed to protect them from woter and weather and to help keep them from leaking to the biosphere by accident or sabotoge.

Enriched Uranium: Uranium in which the percentoge of the fissionable isotope uranium-235 hos been increased above the $0.7 \%$ contained in natural uronium.

Extraction Column: A piece of process equipment which intimately mixes the organic phase and the oqueous phose in the solvent extraction process. Moterial is transported befween the phases.

Extraction Cycle: The use of several extraction columns to separate a wanted product by solvent extraction from other constituents of the feed stream.

Federal Repository: A DOE-controlled facility to be used for the disposol of nuclear waste.

Fertile Material: A material, not itself fissionable by thermal neutrons, that can be converted into a fissile moterial by irradiation in a reoctor. There are two basic fertile materials, uronium-23B and thorium-232. When these fertile materials capture neutrons, they ore partiolly converted into fissile plutonium-239 and uranium-233, respectively.

Finest Calcine dust having the consistency and flow properties of talcum powder.

Fissile Materials: While sometimes used as a synonym for fissionable moterial, this term has also acquired a more restricted meaning, nomely, any material fissionable by reutrons of oll energies, including (and especiolly) thermal (slow) neutrons as well as fust neutrons; for exomple, uranium-235 and plutonium-23\%.

Fission: The splitting of o heovy nucleus into two opproximately equal parts (which are nuclei of lighter elements), accomponied by the releose of a relotively large amount of energy and generally one or more neutrons. Fission con occur spontaneously, but usuolly is coused by nuclear absorption of gummo rays, nautrons, or other particles. 
Fissionable Material: Commonly used as a synonym for fissile moterial. The meaning of this term also has been extended to include moterial that can be fissioned by fast neutrons only, such as uranium-238. Used in reactor operations to mean fuel.

Fission Products (F.P.): The nuclei (fission frogments) formed by the fission of heavy elements, plus the nuclides formed by the fission frogments' radiooc tive decay.

Fluidized Bed: A bed of granular material exponded and agitated by on upflow of gas.

Fuel (muclear, reactor): Fissionable material used as the source of power when placed in a critical arrongement in a nuclear recctor.

Fuel Assembly: An assenibly of fuel elements.

Fuel Cycle: The complete series of steps involved in supplying fuel for nuclear power reactors. It includes mining, refining, the original fabrication of fuel elements, their use in a reactor, chemical processing to recover the fissionable material remaining in the spent fuel, reenrichment of the fuel material, refabrication into new fuel elements, and manogement of radioactive waste.

Fuel Element: A fube, rod, or other form into which fissionable moterial is fabricated for use in a reactor.

Fuel Separation (fuel reprocessing): Processing of irrodiated (spent) nucleor reoctor fuel to recover useful materials as separate products, usually separation into plutonium, uranium, and fission products.

Carnma Rays $(\gamma$ ) High-energy, short-wavelength electromagnetic radiotion emitted by a nucleus. Gamma radiation usually occompanies alpho and beto emissions and always accompanies fission.

Glass-ceramic: A fine-groined, crystalline moterial created by the controlled heating of a gloss.

Holf-life (Th): The time in which half the otoms of a particular radioactive substance disintegratc to another nuclear form. Meosured half-iives vary from millionths of a second to billions or years.

Holf-life, Biological: The time required ior a living organism to eliminate, by natural processes, half the amount of substance that has entered it.

Health Physics: The science concerned with recognition, evaluation, and control of health hazards from ionizing and nucleor radiations.

HEPA: High efficiency particulate air filter. A type of filter designed to remove $99.9 \%$ of particles down to $0.3 \mu \mathrm{m}$ in diameter from a flowing air stream. 
High-Level Liquid Waste O-LLW: The aqueous waste resulting from the operation of the first-cycle extraction system (Purex Process), equivolent concentrated wastes from subsequent extroction cycles, or equivalent wastes from a process not using solvent extraction, in a facility for processing irrudiated reactor fuels.

High-level Waste: (a) high-level liquid waste, or (b) the products from solidificotion of high-level liquid woste, or (c) irrodioted fuel elements, if discarded without processing.

Immobilizution: Treatment and/or emplacement of the wastes so as to impede their movement.

Interim Storage: The storage of wostes in a protected orea while owaiting transfer to a deep geologic reposifory for extended storage or for disposal.

Ion Exchange: A chemical process involving the reversible interchange of various ions between o solution and a solid material, usualiy a resin. It is used to seporate and purify chemicals, such as fission products, rare earths, in solution.

Ionizing Radiotion: Any radiation displocing electrons from atoms or molecules, thereby producing ions. Examples: alpho, beto, and gommo radiation.

Isolation: A term encompossing both final storage and/or disposal in geologic formations.

Isotope: One of two or more otoms with the same otomic number (the same chemical element) but with different otomic weights. An ecuivalent stotement is that the nuclei of isotopes hove the some number of protons but different numbers of neutrons. Isotopes usually have very nearly the some chemicol properties, but somewhat different physical properties.

Licensed Materiol: Source material, special nuclear material, or by-producf material received, possessed, used, or transferred under a generol or special license issued by the U.S. Nuclear Regulatory Commission or an Agreement Stote.

Long-lived isotope: A radioactive nuclide that decays at such a slow rote that a quantity of it will exist for an extended period.

Long-lived Nuclides: Rodioactive isotopes with half-lives greoter than about 30 years. Most long-lived nuclides of interest to woste management have half-lives on the order of thousands to millions of years (Pv-239 $=24,400$ years; Tc-99- $2.1 \times 10^{5}$ years; $\left(-12-1.6 \times 10^{7}\right.$ years).

Man-rem: $A$ unit in health physics to compore the effacts of different amounts of radiation on groups of people. It is obtcined by multiplying the average dose equivalent to a given organ or tissue (measured in rems) by the number of persons in that population. 
Metal-Matrix: A process to fix calcine $i$. u monolithic form by filling the void spoces with molten metal (either u'? binury, or iecd).

Monolith: A dense, solid material incorporating nuclear waste.

Notural (Normal) Uranium: Uranium as found in nature. It is a mixture of the fertile uranium-238 isotope $(99.3 \%)$, the fissionable uronium-235 isotope $(0.7 \%)$, and a minute percentage of uronium-234.

Nonretrievale Solid Transuranic Waste: Any solid transuranic waste that con: toins, or is judged to contain, less thon a specified quantity or concentration of transuranic elements (currently $10 \mathrm{nCi} / \mathrm{g}$ ) and thet may be disposed of in a nonretrievoble manner, but still under conditions that will permit control in a disposal area and minimization of any migration of the transuranic elements. Included in this categary are wastes contaminated with high beta-gammo emitters.

Normal Retrievble Waste: Wastes containing more than $10 \mathrm{nCi} / \mathrm{g}$ of transuranic isotopes and less than the recovery limit for that type of material as determined by the site.

Nuclide: A species of atom having a specific moss, atomic number, and nuclear energy state. These factors determine the other properties of the element, including its radioactivity.

Off-gas: Gas released by any process in fuel reprocessing or nuclear waste monogement.

Organic-Phase: The liquid phase in solvent extroction which consists of the organic solvent and the organic dilvent.

Overpack: Secondary (or additional) external containment for pockaged nucleor woste.

Partition: The chemical separation of actinides from other fission products.

$\mathrm{pH}$ : A meosure of the hydrogen ion concentration in oqueous solutions. Acidic solutions have o $\mathrm{pH}$ from zero to 7 . Bosic solutions have a $\mathrm{pH}$ from 7 to 14 .

Pits An excavation for the disposol of miscellaneous oqueays and organic wastes, some of which may be contominated with tritium, fission products, ar activation products.

Plutonium (Pu): A heavy, radioactive, man-made, metollic element with atamic number 94. Its most important isotope is fissionuble plutonium-239, produced by neutron irradiation of uranium-238. It is used for reactor fiel and in weopons.

Primary Wastest As-generated forms ond quantities of wastes.

Production Reactor: A nuclear reactor designed primarily for large-scale production of plutonium, tritium, and other radionuclides by neutron irradiotion. 
Process-Gsiar nted Wastes: Those wastes that ore generated by, or are the result of, process operations in ihe enclosure defining the process lines and related equipment. In general, the TRU contaminotion levels will be significant.

Purexe A solvent extraction process in which uranium and plutanium are selectively separated from each other and from fission products by extraction from nitric acid solutions with tributylphosphate in a hydrocorbon diluent.

Rod (ocronym for radiotion absorbed dose): The basic unit of absorbed dose of ionizing rodiation.

Rodiation: The emission and propogation of energy through matter or space by mesns of electromagnetic disturbances, which disploy both wove-like and porticle-like behavior; in this context the "porticles" are known os photons. Also, the energy so propagated. The term hos been extended to include streans of fast-moving porticles (alpho and beto particles, neutrons, cosmic radiation, etc.). Nuclear radiation is that emitted from atomic nuclei in vorious nuclear reactions, including alpho, beta, and gammo rodiotion and neutrons.

Radioactive Contamination: Deposition of radioactive material in any place where it may harm persons, spoil experiments, or make products or equipment unsuitoble or unsufe for some specific use. The presence of unwanted radioactive motter. Also rodiooctive material found on the walls of vessels in used-fuel processing plonts, or rodioactive moterial that hos leoked into a reactor coolant. Often referred to only os contamination.

Radiooctive Waste: Materials of no value consisting of, including, or contaminated with rodionctive material in excess of the levels or consentrations permit ted for unconditional release of such moterials.

Radioactivity (often shortened to "activity"): The spantaneous decay or disintegration of an unstable atomic nucleus, usually accomponied by the emission of ionizing radiation. The word rodicastivity is often used to refer to radiooctive materials or radioactive nunlides, but this usage is not, strictly speaking, correct. Rodiocctivity is a process, not a substance.

Rodioisotope: A radioactive isotope. An unstoble isotope of an element that decoys or disintegrotes spontoneousl/, emitting rodiation. More than !,300 notural and artifical radioisotopes have been identified.

Rodionuclide: An unstable nuclide of on element that decoys or disintegrates spontaneously, emitting radiation.

Rodwaste: See Radioactive Woste abova.

Roffinate: The woste stream containing fission produ:ts from an extroction column. 
Reoctor: $A$ device by means of which a fissibil choin reoction con be iniliated, maintained, and conirolled.

Recovery: The reprocessing of TRU contaminated materials for the purpose of reclaiming and reusing the transuronic elements which they contain.

Rem: A unit of meosure for the dose of ionizing radiation that gives the same biological effect as I roentgen of $x$ roys; 1 rem equals approximately 1 rad for $X$, gamma, or beta rodiation.

Repository: A federally owned and operored focility for storage or disposcl of specific types of rodiooctive woste from DOE sites ond/or NRC licensees.

Resin: A synthetic organir polymer that con act as an ion exchanger.

Retrievoble Solid Tronsurnic Woste: Any solid tronsuranic waste that contains, or is judged to contain, $m$ ire than a specified quantity or concentration of ironsuranic elements (curranily $10 \mathrm{nCi} / \mathrm{g}$ ) and must, as a result, be ploced into interim storoge for eventual disposition.

Retrievable Storoce: "Solid waste generated at DOE sites and containing significant U-233 on transuranium nuclide contamination sholl be stered of DOE sites, segregated from other radiooctively contaminated solid waste and with combustible and noncombustible tronsuranis'm-contaminated waste pockoged separately. The packoging and storage carditions shall be such that the packoges can be readily retrieved in on intact, contamination-free condition for $a$ years. The packages shall be suitably labeled so the waste they contain can be identified by cross reference to permanent records." (DOE Manual 0511--Radiacctive Waste Management)

Roentgen (abbraviation r): A unit of exposure to ionizing radiation. It is that amount of gammo or $X$ roys required to prodice ions carrying one (I) electrostatic unit of electrical charge (either positive ar negativis) in one (1) cubic centimeter of dry oir under standard conditions. Named ofter Wilheirn Roentgen, Germon scientist who discovered $X$ rnys in 1895.

Room-Generated Wostes: Those wastes that are generated by, or are the result of, suppori operations in the room or area containing the transuroric processing facilities. These materials are usually of considerably lower contamination level than wastes generajed in process lines.

Salt Cake: The remaining product of high-level liquid woste when evaporoted to dryress without agitation.

Scrop: The feed materials for a TRU recovery precess, that is, the transuraniccontaminated materials which ore discarded from a process bu if which contain sufficient transuranic elements to warront recovery.

Secondary Wostes: Forms and quantities of all wastes that result from opplying woste treatment technologies to primary wostes. 
Separations: Chemical prosesses used to seporate nucle.tr products from byproducts and from each other.

Short-lived botope: A radiooctive nuclide that decays so ropidly that a given quantity is tronsformed into its doughter prosucts within a short period (usually those with o holf-life of doys or less).

Short-lived Nuclides: Radiooctive isotopes with holf-lives no greater than obout 30 yeors, $e_{-3}, 1, \mathrm{Cs}-137$ and $5 r-90$.

Solidification: Conversion of radiooctive waste to o dry, stable solid.

Solid Rodiooctive Waste: Radiooctive waste moterial that is essentially dry but may contain sorbed rodiooctive fluid in sufficiently small amants to be immobile when buried in dry soil.

Solvent Extroction: A process in which materials are selectively removed from an oqueous solution by contact with an immiscible organic soivent.

Speciol Nuclear Material (SNM): Plutonium, uranium-233, uranium-235, or uranium enriched to a higher percentage than normal of the -233 or -235 isotopes.

Storoge: Retention of rodiocetive waste in some type of man-mode engineered device (e. $g$, tonk) in o manner permitting retrievol.

Storage Area The oreo in which the storage fociity is locoted (i.e., the site of the storoge facility).

Storoge Focility The octual place of stornge of wostes. This may be on engineered strucfure such as o building or vouit or o protected area in any other type of focility.

Tank: A large metal container locaied above ground or underground for storage of liquid wostes.

Tonk Form: An installation of interconnected underground containers (tanks) for storage of high-level woste.

Tronsmutotion: Conversion of o radiaactive nucleus to another isotope by hombarding it with rodiation or nuclear porticles.

Tronsportation: Movernent of materials between sites. Intrcsite movement is not considered. Includes olternotive methods for pockoging, hondling, and transport of waste materials. Concapts include oll conventional methods of land and water transport required by the waste management system.

Tronsuranic Waste: Any waste material measured or assumed to contain more than a specified concentration (e.g., presently 10 nonccuries of transuranium activity per gram of wastej of transuranic elements. 
Trassuraniume Nuslides having on atomic number greater than thot of uranium (i.e., greater than 9?). The principal transuranic radionuclides of concern in radioactive waste management are tabulated below with their half-lives:

\begin{tabular}{|c|c|c|}
\hline Nuclide & $\begin{array}{l}\text { Holf-Life } \\
\text { (Years) }\end{array}$ & Principal Decoy Modes \\
\hline neptunium-237 & $2,140,000$ & olpho \\
\hline piutonium-238 & 86 & alpha, spentoneous fission \\
\hline plutonium-239 & 24,390 & olpha, spontaneous fission \\
\hline plutonium-240 & 6,580 & olpho, spontaneous fission \\
\hline plutonium-242 & 379,000 & alpho \\
\hline omericium-241 & 458 & olpho \\
\hline omericium-243 & 7,950 & olpha \\
\hline curium-245 & 9,300 & alpho \\
\hline curium-246 & 5,500 & olphe, spontaneous fission \\
\hline
\end{tabular}

The transuranium nuclide produced in lorgest amounts is plutoniurn-239; omericium-241 is also produced in significant amounts, One system of classification used of Ook Ridge includes U-235 (I62,000 yeor half-life, olpho decay) among the tronsuranium isotopes, although strictly speaking this is not accurate. For further discussion see Appendix 8 .

Treatment: Operations intended 's benefit sofety or economy by chonging the waste choracteristics. Four bosic treatment concepts are defined:

- Volume reduction

- Immobilization of radiooctivity

- Change of composition

- Removal of rodicoctivity from the waste

Trench: A long and narrow excovation in the ground for solid waste. Unless qualifying descriptions are given, o trench is unlined, and its walls are unsupported. After, the solid wostes are ploced in position, the trench is filled to grade level with some of the removed soil.

Uranium: A rodioactive element with the otomic number 92 and, as found in notural ores, on averoge otomic weight of approximately 238 . The two principal naturai isotopes are U-235 (0.7 percent of notural uranium), which is fissionable, and U-238 (99.3 percent of natural uranium), which is fertile. Natural uranium olso includes a minute amount of U-234.

Vitrification: The process of forming an amorphous os opposed to crystalline structure-a olossing process. 
Woste Contoiner: The device or devices, including liners and closuses, used in the pockoging of wostes.

Waste Pockoge: The firol configuration of the woste in its contoiner os it is ready to be ploced into interim storoge or finol geologic disposal. 
ABBREVIATIONS

AEC United States Atomic Energy Commission

ALARA As low as reasonably achievable

DOE United States Deportment of Energy

DF Decontamination factor

ERDA United States Energy Research and Development Administration

HLLW High level liquid waste

ICPP idaho Chemical Processing Plant

ICRP International Commission of Radiological Protection

ILLW Intermediate level! liquid waste

NEL Idaho National Engineering Laboratory

MTU Metric ton uranium

NRC United States Nuclear Regulatory Commission

TEP Tributyl phosphate

WCF Waste Calcining Facility

A-13 


\section{SYMBOLS OF THE ELEMENTS}

\begin{tabular}{|c|c|c|}
\hline octinium & $A c$ & godolinium \\
\hline aluminium & Al & gollium \\
\hline omericium & $\mathrm{Am}$ & germanium \\
\hline ontimony & Sb & gold \\
\hline argon & $A r$ & hafrium \\
\hline arsenic & As & helium \\
\hline astotine & At & holmium \\
\hline borium & Bo & hydrogen \\
\hline berkelium & $\mathrm{Bk}$ & indium \\
\hline beryllium & $\mathrm{Be}$ & iodine \\
\hline bismuth & $B i$ & iridium \\
\hline boron & $\mathrm{B}$ & iron \\
\hline bromine & $\mathrm{Br}$ & krypton \\
\hline codmium & Cd & lanthorum \\
\hline coesium & $C_{s}$ & lead \\
\hline colcium & Co & lithium \\
\hline colifornium & $\mathrm{Cf}$ & lutetium \\
\hline carbon & $C$ & mognesium \\
\hline cerium & $\mathrm{Ce}$ & monganese \\
\hline chlorine & $\mathrm{Cl}$ & mendelevium \\
\hline chromium & $\mathrm{Cr}$ & mercury \\
\hline cobolt & Co & malybdenum \\
\hline copper & $\mathrm{Cu}$ & neodymium \\
\hline curium & $\mathrm{Cm}$ & reon \\
\hline dysprosium & Dy & nepfunium \\
\hline eirsteinium & Es & nickel \\
\hline erbium & $\mathrm{Er}$ & niobium \\
\hline europium & EU & nitrogen \\
\hline fermium & $F_{m}$ & nobelium \\
\hline fluorine & $F$ & osmium \\
\hline \multirow[t]{2}{*}{ francium. } & $\mathrm{Ft}$ & oxygen \\
\hline & & polladium \\
\hline
\end{tabular}

A-14 


\section{SYMBOLS OF THE ELEMENTS}

(CONT.)

\begin{tabular}{|c|c|c|}
\hline phosphorus & $P$ & fungsten \\
\hline platinum & $P_{4}$ & uronium \\
\hline plutonium & $\mathrm{Pu}$ & vonadium \\
\hline polonium & Po & $x$ xenon \\
\hline potassium & $k$ & ytterbium \\
\hline proseodymium & $\operatorname{Pr}$ & yttrium \\
\hline promethium & $\mathrm{Pm}$ & zinc \\
\hline protoctinium & Po & zirconium \\
\hline radium & Ro & \\
\hline radon & $\mathrm{Rn}$ & \\
\hline rhenium & $\operatorname{Re}^{\prime}$ & \\
\hline rhodium & Rh & \\
\hline rubidium & $\mathrm{Rb}$ & \\
\hline ruthenium & Ru & \\
\hline somarium & Sm & \\
\hline scandium & Se & \\
\hline seleniurr. & $\mathrm{Se}$ & \\
\hline silicon & Si & \\
\hline silver & $\mathrm{Ag}$ & \\
\hline sodium & No & \\
\hline strontium & Sr & \\
\hline sulphur & 5 & \\
\hline tontolum & To & \\
\hline technetium & Tc & \\
\hline tellurium & $\mathrm{Te}$ & \\
\hline terbium & $\mathrm{Tb}$ & \\
\hline thallium & $\mathrm{TI}$ & \\
\hline thorium & Th & \\
\hline thulium & Tm & \\
\hline $\operatorname{tin}$ & in & \\
\hline titonium & $\mathrm{Ti}$ & \\
\hline
\end{tabular}

A. 15 


\section{FACTORS FOR CONYERTING UNTS TO SI SYSTEM EQUIVALENTS}

SI bose units ore the meter (m), kilogrom (kg), second (s), ompere (A), kelvin (K), candelo (cd) and mole (mol). (For further information, see International Standards 1501000 (1973), and 150 31/0 (1974) and its severol parts.)

Multiply by to obtoin

Moss

paund mass (ovoirdupois) ton (short) $(=2000 \mathrm{lbm})$

tonne ( = metric ton)

$$
\begin{array}{ll}
\text { I lbm } & =4.536 \times 10^{-1} \\
\text { istort ton } & =9.072 \times 10^{2} \\
\text { it } & =1.00 \times 10^{3}
\end{array}
$$

$\mathrm{kg}$

$\mathrm{kg}$

Length

$\begin{array}{llll}\text { stotute mile } & \text { I mile } & =1.609 \times 10^{0} & \mathrm{~km} \\ \text { yord } & 1 \mathrm{rd} & =9.144 \times 10^{-1} & \mathrm{~m} \\ \text { foot } & \text { I } & =3.048 \times 10^{-1} & \mathrm{~m} \\ \text { inch } & \text { I in } & =2.54 \times 10^{-2} & \mathrm{~m} \\ \text { mil }\left(=10^{-3} \mathrm{in}\right) & \text { I mil } & =2.54 \times 10^{-2} & \mathrm{~mm}\end{array}$

Areo

foot $^{2}$

$\begin{array}{ll}\text { lacre } & =4.047 \times 10^{3} \\ 1 \mathrm{ft}^{2} & =9.290 \times 10^{-2}\end{array}$

$m^{2}$

Volume

yord
foot $_{3}^{3}$
inch
gallon (US liquid)
litre

$\begin{array}{ll}\mid \mathrm{yos}_{3}^{3} & =7.646 \times 10^{-1} \\ 1 \mathrm{ft}^{3} & =2.832 \times 10^{-2} \\ 1 \text { in } & =1.639 \times 10^{4} \\ \text { lgol(US) } & =3.785 \times 10^{-3} \\ 11 & =1.00 \times 10^{-3}\end{array}$

$m_{3}^{3} m^{3}$

Force

$\begin{array}{llll}\text { dyne } & \text { I dyn } & =1.00 \times 10^{-5} & \mathrm{~N} \\ \text { kilogram force } & \text { I kgf } & =9.807 \times 10^{0} & \mathrm{~N} \\ \text { pound force (ovoirdupois) } & \text { I lbf } & =4.448 \times 10^{0} & \mathrm{~N}\end{array}$




\section{FACTORS FOR CONVERTING UNIS TO SI SYSTEM EQUIVALENTS \\ (CONT.)}

\begin{tabular}{lll}
\hline Multiply & by & to obtain \\
\hline
\end{tabular}

Density

$\begin{array}{llll}\text { pound mass/inch } & 3 & 1 \mathrm{lbm} / \mathrm{in}_{3}^{3}=2.768 \times 10^{4} & \mathrm{~kg} / \mathrm{m}_{3}^{3} \\ \text { pound moss } / \mathrm{foot}^{3} & 1 \mathrm{lbm} / \mathrm{ft}^{3}=1.602 \times 10^{1} & \mathrm{~kg} / \mathrm{m}^{3}\end{array}$

\section{Energy}

$\begin{array}{llll}\text { British thermal unit } & \text { I Bty } & =1.054 \times 10^{3} & \mathrm{~J} \\ \text { colorie } & \text { cal } & =4.184 \times 10^{-7} & \mathrm{~J} \\ \text { erg } & \text { lerg } & =1.00 \times 10^{-7} & \mathrm{~J} \\ \text { kilowatt-hour } & \text { l kW.h } & =3.60 \times 10^{6} & \mathrm{~J}\end{array}$

\section{Pressure}

\begin{tabular}{|c|c|c|}
\hline $\begin{array}{l}\text { newtons/meter }{ }^{2} \\
\text { atmosphere } \\
\text { dyne/centimetre } 2 \\
\text { kilogrom force/centimetre } \\
\text { pound force/foo: }\end{array}$ & $\begin{array}{l}1 \mathrm{~N} / \mathrm{m}^{2} \\
1 \mathrm{otm} \\
1 \mathrm{dyn} / \mathrm{cm}^{2} \\
1 \mathrm{kgf} / \mathrm{cm}^{2} \\
1 \mathrm{lti} / \mathrm{ft}^{2}\end{array}$ & $\begin{array}{l}=1.00 \\
=1.013 \times 10^{5} \\
=1.00 \times 10^{-1} \\
=9.807 \times 10^{4} \\
=4.788 \times 10^{1}\end{array}$ \\
\hline
\end{tabular}

Temperature, thermol conductivity, energy/areo. time

\begin{tabular}{|c|c|c|}
\hline 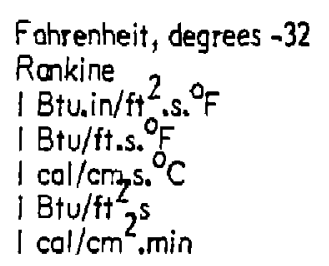 & $\begin{array}{l}{ }^{O} F-32 \\
{ }^{0} F\end{array}$ & $\begin{aligned} & \frac{5}{9} \\
= & 5.189 \times 10^{2} \\
= & 6.226 \times 10^{1} \\
= & 4.184 \times 10^{2} \\
= & 1.135 \times 10^{4} \\
= & 6.937 \times 10^{2}\end{aligned}$ \\
\hline
\end{tabular}

Miscellaneous

foot $3 /$ second
foot $/$ minute
rad
soentgen
curie

$$
\begin{array}{ll}
1 \mathrm{ft}^{3} / \mathrm{s} & =2.832 \times 10^{-2} \\
1 \mathrm{ft}^{3} / \mathrm{min} & =4.719 \times 10^{-4} \\
\mathrm{rad} & =1.00 \times 10^{-2} \\
\mathrm{R} & =2.580 \times 10^{-4} \\
\mathrm{Ci} & =3.70 \times 10^{10}
\end{array}
$$

$\mathrm{m}_{3}^{3} / \mathrm{s}$
$\mathrm{J} / \mathrm{sg}$
$\mathrm{C} / \mathrm{kg}$
disintegration $/ \mathrm{s}$ 
APPENDIX $B$

TRANSURANIUM RADIONUCLIDES

AN OVERVIEW OF CHEMICAL, PHYSICAL

AND RADIOLOGICAL PROPERTIES 


\section{INTRODUCTION}

The transuronium radionuclides are those nuclides with atomic numbers 93 to 103, inclusive. Table $B-1$ gives the otomic numbers, names and chemical symbols of this group of elements. Table B-2 presents various physical characteristics of olpha-emitting TRU isotopes with half-lives greater than 100 doys.

No known nuclides of the transuronium elements are srable. In general, the higher the ctomic number of the element, the shorter the half-life.

Plutonium is the best known of the transuranium radionuclides and it is common to compore the properties of this group of radionuclides to plutonium. This group of radionuclides is highly radioactive and hos a high specific activity, i.e. there are many curies, $\mathrm{Ci}$, of radioactivity for each gram of nuclide.

The relatively high energy releose per nuclear decay and the general tendency of these nuclides to concentrate in bone tissue leads to a highly toxic effect when these nuclides are present within the human body. On a Ci or rodioactivity basis, the transuranium rodionuclides are not greatly different from plutonium in their toxicity. On a mass or gram basis, however, some of these radionuclides are a factor of $10^{4}$ times more toxic than plutonium. Their extremeiy high toxicity per unit mass requires that extraordinory precoutions and care need to be token when working with these materials. These radionuclides require a skill and a specially designed complement of equipment for handling that far exceeds that required for the more common fission product radionuclides. It is necessory to plan diligently with expert knowledge to design and operate safe transuranium processing and hondling facilities.

Experience in working with fission products or uronium is helpful in planning transuranium radionuclide work and activities, but such experience cannot be translated to working with these high specific activity materials. The contaminotion control requirements are $10^{3}$ to $10^{6}$ times more rigid for the transuranium radionuclides than for the typical fission product radionuclides. 


\section{TABLE B-I}

TRANSURANIUM ELEMENTS

\begin{tabular}{|c|c|c|}
\hline $\begin{array}{l}\text { Atomic } \\
\text { Number }\end{array}$ & Element Nome & $\begin{array}{l}\text { Chemica } \\
\text { Symbol } \\
\end{array}$ \\
\hline 93 & Neptunium & $N p$ \\
\hline 94 & Plutonium & Pu \\
\hline 95 & Americium & Am \\
\hline 96 & Curium & $\mathrm{Cm}$ \\
\hline 97 & Berkelium & $B k$ \\
\hline 98 & Colifornium & $\mathrm{CF}$ \\
\hline 99 & Einsteinium & Es \\
\hline 100 & Fermium & $\mathrm{Fm}$ \\
\hline 101 & Mendelevium & Md \\
\hline 102 & Nobelium & No \\
\hline 103 & Lowrencium & $L w$ \\
\hline
\end{tabular}


TABLE B-2

ALPHA-EMITTING TRU ISOTOPES

WITH HALF-LIFE GREATER THAN 100 DAYS 28

\begin{tabular}{|c|c|c|c|c|c|c|c|c|}
\hline Isotope & $\begin{array}{l}T_{1 / 2} \\
(y t)\end{array}$ & $\begin{array}{c}T(S F) \\
H / 2 \\
(y r)\end{array}$ & $\begin{array}{l}\text { Therral Neutron } \\
\text { Cross Sections } \\
\text { (batn) }\end{array}$ & $\begin{array}{l}\text { Specific } \\
\text { Activity } \\
\text { (g/ch) }\end{array}$ & $\begin{array}{l}\text { (SF) Aetivity } \\
\text { (fIssion/ } \\
\text { sec-g) }\end{array}$ & $\begin{array}{c}V \\
(S F)\end{array}$ & Parent & Daughet \\
\hline & $1.62 \times 10^{5}$ & & $\begin{array}{l}=49 \\
7 \cdot 524\end{array}$ & $1,05 \times 10^{2}$ & 20 & & $\begin{array}{l}233_{\mathrm{Pa}} \\
233_{\mathrm{YP}}\end{array}$ & ${ }^{229} \mathrm{mh}$ \\
\hline$-37^{3}, y_{p}$ & $2.16 \times 10^{5}$ & $20^{18}$ & $\begin{array}{l}z_{1}=170 \\
\therefore=0.019\end{array}$ & $1.22 \times 10^{3}$ & $.5 .6 \times 10^{-5}$ & & $\begin{array}{l}237 \\
261 \\
237\end{array}$ & $23 \mathrm{PP}_{\mathrm{Pa}}$ \\
\hline${ }_{96}^{236} \mathrm{P}_{4}$ & $2.85 \cdot 10^{0}$ & $3.5 \cdot 10^{9}$ & $z_{i} \cdot 170$ & $1.88 \times 10^{-3}$ & $1.6 \cdot 10^{4}$ & & 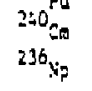 & 232 \\
\hline 2389 & $8.54 \cdot 10^{2}$ & $4.9 \cdot 10^{10}$ & $\begin{array}{l}\because=500 \\
\because=16.8\end{array}$ & $5.75 \times 10^{-2}$ & $1.13 \cdot 10^{3}$ & 2.26 & 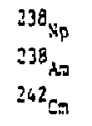 & ${ }^{234} \mathrm{v}$ \\
\hline$-39 p_{4}^{-39}$ & $\therefore: 4: 0^{\circ}$ & $3.5 \cdot 10^{25}$ & $\begin{array}{l}z_{c}=274 \\
z_{i}=741\end{array}$ & $1.63 \times 10^{1}$ & $1.00 \cdot 10^{-2}$ & 2.2 & $\begin{array}{r}239 \mathrm{yp} \\
293 \mathrm{Cm} \\
=2399_{\mathrm{Am}}\end{array}$ & $235=$ \\
\hline 200 & $0.50 \cdot 10^{3}$ & $1.14 \times 10^{11}$ & $\begin{array}{l}z=296 \\
z_{f}=0.08\end{array}$ & $4.4 \cdot 10^{0}$ & $4.1 \cdot 10^{2}$ & 2.17 & $\begin{array}{l}246 \mathrm{~cm} \\
340 \mathrm{ch} \\
240 \mathrm{im}\end{array}$ & ${ }^{236} \mathrm{U}$ \\
\hline$\because: a_{9} \mathrm{Pu}$ & $3.79 \times 10^{5}$ & $\therefore 1 \times 10^{10}$ & $\begin{array}{l}c_{c}=19 \\
z_{E}=0.2\end{array}$ & $2.57 \times 10^{2}$ & $7,7 \cdot 10^{2}$ & 2.16 & $\begin{array}{l}246_{\mathrm{Cm}} \\
2422_{\mathrm{AM}}\end{array}$ & $238_{\mathrm{Q}}$ \\
\hline $\begin{array}{l}344 \\
94\end{array}$ & $7.7 .6 \times 10^{7}$ & $2.5 \cdot 10^{10}$ & $\therefore=2,8$ & $.5 .2 \times 10^{4}$ & $2.7 \cdot 10^{3}$ & & ${ }^{248} \mathrm{C}_{\mathrm{F}}$ & $\begin{array}{l}200 ! ! \\
F . P .\end{array}$ \\
\hline $2: 1_{\text {Am }}$ & $4.53 \times 10^{2}$ & $2 \cdot 10^{12}$ & 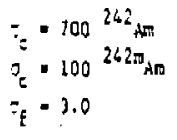 & $3.08 \times 10^{-3}$ & $\therefore \therefore+10^{-1}$ & 2.3 & $\begin{array}{l}241_{P \mathrm{~V}} \\
24 j_{\mathrm{Bk}} \\
241_{\mathrm{Cm}}\end{array}$ & 237 \\
\hline $2: 2 \frac{3 \pi}{95^{2}}$ & $2.52 \cdot 10^{2}$ & & $\begin{array}{l}z_{c} \cdot 2000 \\
J_{y} \cdot 6000\end{array}$ & $1.03 \cdot 10^{-1}$ & & & -2 & $\begin{array}{l}\therefore: 2 \mathrm{Am} \\
\therefore 33_{\mathrm{Xg}}\end{array}$ \\
\hline 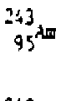 & $7.95 \times 10^{3}$ & & $\begin{array}{l}J_{c}=74 \\
c_{f}=<0.07\end{array}$ & $5.20 \cdot 10^{0}$ & & & $\begin{array}{l}343 \mathrm{Pu} \\
247 \mathrm{Bk}\end{array}$ & 294 \\
\hline${ }_{96}^{142} \mathrm{Cos}$ & $4.45 \times 10^{-1}$ & $7.2 \times 10^{6}$ & $\begin{array}{l}0_{5}=20 \\
0_{f}<5\end{array}$ & $3.01 \cdot 10^{-4}$ & $7.58 \times 10^{6}$ & & $\begin{array}{l}2: 2 \mathrm{dr} \\
3: 4 \mathrm{Cf}\end{array}$ & $\begin{array}{l}{ }^{238} \mathrm{Pu}_{\mathrm{u}} \\
\text { F.P. }\end{array}$ \\
\hline${ }_{96}^{263}$ & $3.2 \times 10^{1}$ & & $\begin{array}{l}J_{c}=250 \\
c_{t}=662\end{array}$ & $2.2 \cdot 10^{-2}$ & & & $34]_{B K}$ & 239 \\
\hline
\end{tabular}




\section{TABLE B-2}

(CONT.)

\begin{tabular}{|c|c|c|c|c|c|c|c|c|}
\hline Leotope & $\begin{array}{l}T_{1 / 2} \\
(r)\end{array}$ & $\begin{array}{c}T(S F)_{1 / 2} \\
(y r)\end{array}$ & $\begin{array}{l}\text { Thireal Neutron } \\
\text { Croun Sustione } \\
\text { (burs) }\end{array}$ & $\begin{array}{c}\text { Specific } \\
\text { Activity } \\
\text { (z/LI) }\end{array}$ & $\begin{array}{c}\text { (SF) Aetivity } \\
\text { (flation/ } \\
\text { uec-t) }\end{array}$ & $\underset{\text { (SF) }}{v}$ & Paront & Doutheer \\
\hline${ }_{95}^{246}$ & $1,76 \times 10^{1}$ & $1.31 \times 10^{7}$ & $g_{c} \cdot 15$ & $1.2 \times 10^{-2}$ & $4.24 \times 10^{6}$ & & $\begin{array}{l}268 \mathrm{Cr} \\
264 \mathrm{Am} \\
266 \mathrm{mb}\end{array}$ & $\begin{array}{l}240_{\mathrm{PL}} \\
7.8 .\end{array}$ \\
\hline${ }_{96}^{245} \mathrm{Cx}$ & $9.3 \times 10^{3}$ & & $\begin{array}{l}\theta_{L}=200 \\
\sigma_{f}=1900\end{array}$ & $6.4 \times 10^{0}$ & & & $\begin{array}{l}249 \mathrm{ct} \\
245_{\mathrm{NE}} \\
245_{\mathrm{Bk}}\end{array}$ & $241 \mathrm{pu}$ \\
\hline $\begin{array}{l}246 \\
96\end{array}$ & $5.5 \times 10^{3}$ & $1.7 \times 10^{7}$ & $0_{5}=15$ & $3.8 \times 10^{0}$ & $3.2 \times 10^{6}$ & & $\begin{array}{l}{ }^{250} \mathrm{Cr} \\
246 \mathrm{AB} \\
246 \mathrm{BK}\end{array}$ & 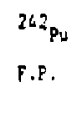 \\
\hline $96^{\mathrm{Cs}^{267}}$ & $2.6 \times 10^{7}$ & & $o_{c}=180$ & $1.1 \times 10^{4}$ & & & 267 & ${ }^{24} 3_{\mathrm{Pu}}$ \\
\hline $96^{\mathrm{Cs}^{248}}$ & $4.7 \times 10^{5}$ & $4.6 \times 10^{6}$ & $\sigma_{c}=6$ & $3.27 \times 10^{2}$ & $1.26 \times 10^{7}$ & & $\begin{array}{l}25 ? \mathrm{Cl} \\
248 \mathrm{gk}\end{array}$ & $\begin{array}{l}{ }^{246} \mathrm{Pu} \\
\text { F.P. }\end{array}$ \\
\hline $9 t^{\mathrm{Ce}} 250$ & & $1.1 \times 10^{4}$ & & & $3.1 \times 10^{9}$ & & $24 \overline{S G}$ & F.? \\
\hline $\begin{array}{r}247 \\
97\end{array}$ & $1.4 \times 10^{3}$ & & & $9.66 \times 10^{-1}$ & & & ${ }^{2+1} \mathrm{CE}$ & $243 \mathrm{Az}$ \\
\hline${ }_{9 B}^{248}$ & $9.59 \times 10^{-1}$ & $21.5 \times 10^{4}$ & & $0.64 \times 10^{-6}$ & $23.6 \cdot 10^{9}$ & & $\begin{array}{l}25 i_{\mathrm{FE}} \\
268_{\mathrm{ph}}\end{array}$ & $\begin{array}{ll}24 . \\
F\end{array}$ \\
\hline${ }_{98}^{249}$ & $3.60 \times 10^{2}$ & $2.5 \times 10^{9}$ & $\begin{array}{l}\sigma_{c}=270 \\
a_{f}=1735\end{array}$ & $2.51 \times 10^{-2}$ & $2.5 \times 10^{6}$ & & $\begin{array}{l}249 \mathrm{gk} \\
24 \mathrm{gk}_{\mathrm{Es}}\end{array}$ & $\begin{array}{l}346 \mathrm{cos} \\
\text { F.?. }\end{array}$ \\
\hline${ }^{250} \mathrm{CE}$ & $2.32 \times 10^{2}$ & $1.7 \times 10^{4}$ & $\begin{array}{l}o_{c}=2500 \\
o_{f}=<350\end{array}$ & $9.24 \times 10^{-3}$ & $3 . \therefore \times 10^{9}$ & & $\begin{array}{l}{ }^{254} \mathrm{fb} \\
250 \mathrm{gk} \\
250 \mathrm{Es}\end{array}$ & $\begin{array}{l}{ }^{246} \mathrm{CDO} \\
\text { t.P. }\end{array}$ \\
\hline${ }_{98}^{251} \mathrm{Cf}$ & $4 \times 10^{2}$ & & $\begin{array}{l}\sigma_{c}=3000 \\
\sigma_{f}=3000\end{array}$ & $26 \times 10^{-1}$ & & & $\begin{array}{l}25 S_{\mathrm{FIS}} \\
25 \mathrm{i} \mathrm{ESS}\end{array}$ & $24{ }^{\circ} \mathrm{cos}$ \\
\hline${ }_{98}^{252}$ & $2.65 \times 10^{0}$ & $8.5 \times 10^{2}$ & $0_{c}=30$ & $1.86 \times 10^{-3}$ & $6.2 \cdot 10^{11}$ & 3.8 & $2^{56} \mathrm{Fm}$ & $\begin{array}{l}248.7 \\
8.7 .\end{array}$ \\
\hline${ }_{99}^{252}$ & $43.86 \times 10^{-1}$ & & & $2.7 \times 10^{-4}$ & & & ${ }^{256} \mathrm{Kd}$ & $249 \mathrm{k}$ \\
\hline${ }_{99}^{234}$ & $7.56 \times 10^{-1}$ & $7 \times 10^{3}$ & $\theta_{e}<40$ & $3.4 \cdot 10^{-6}$ & $7.4 \times 10^{7}$ & & -1 & $\begin{array}{l}250_{\mathrm{Bk}} \\
\text { E.P. }\end{array}$ \\
\hline
\end{tabular}

chas os parent 1sotope but to produced by $a(n, y)$ reaction. 
The transuranium elements ore normally produced by neutron irradiation of uranium or higher atomic number elements in a nuclear reactor. The transuranium radionuslides are also preduced in thermcnuclear explosions and by accelerators. Reactor irradiation is usually the preferred method of production when more than trace quantities of a nuclide are desired.

The major differences between the :ransuranium radionuclides and uranium are the greater spesific activity, shorter spontaneous fission half-lives, and the larger riumber of $X$-roy and gammo-ray photons emitted per disintegration of the transuranium radionuclides. In handling or processing these nuclides one is confronted not only with dose rates that may require extensive shielding, but also with the problem of ensuring that radionuclides do not escape into the work environment and enter the body by inhalation, ingestion or other methods. Table B-3 presents maximum permissible cancentration (MPC) values for the major TRU isotopes.

The high specific activities require an exceptional degree of diligence in all manipuiotions to assure contra, and absolute containment. The lass of control over even the slightest amo:jnt, by ony narmal stardards of measuremint, of a transururium redionuclide con lead to serious hazards and timely and costly decontamination requirements. The futentia! for difficulties in handling and working with transuranium radionuclides depends upon the type of operation to be performed as well as the physical properties of the particular nuclide being used.

\section{PHYSICAL PROPERTIES}

\section{Modes of Decay}

Most transuranium radionuclides emit alpha paiticles. Many also emit neutrons and some emit beta particles. Most particle emissions are accompanied by $X$-roy or gamma-ray emissions of relatively low energy, usually a few tens of kilovolts. 
TABLE B-3

MAXIMUM PERMISSIBLE

CONCENTRATIONS IN AIR AND WATER ABOVE NATURAL BACKGROUND

\begin{tabular}{|c|c|c|c|c|c|c|}
\hline \multirow[b]{2}{*}{ TRU ELEMENT } & \multirow{2}{*}{\multicolumn{2}{|c|}{ ISOTOPEI }} & \multicolumn{2}{|c|}{ RESTRICTED AREA ${ }^{2}$} & \multicolumn{2}{|c|}{ UNRESTRICTED AREAS ${ }^{3}$} \\
\hline & & & $\begin{array}{c}\text { AIR } \\
(\mu \mathrm{Ci} / \mathrm{ml}) \\
\end{array}$ & $\begin{array}{c}\text { WATER } \\
(\text { LCi/ml) }\end{array}$ & $\begin{array}{c}\text { AIR } \\
(. \mathrm{Ci} / \mathrm{m} \mid)\end{array}$ & $\begin{array}{l}\text { WATER } \\
(\text { (. Cilminl) }\end{array}$ \\
\hline \multirow[t]{10}{*}{ Americium } & $\operatorname{Am} 241$ & $S$ & $6 \times 10^{-12}$ & $1 \times 10^{-4}$ & $2 \times 10^{-13}$ & $4 \times 10^{-6}$ \\
\hline & & । & $1 \times 10^{-10}$ & $8 \times 10^{-4}$ & $4 \times 10^{-12}$ & $3 \times 10^{-5}$ \\
\hline & $A m 242 m$ & 5 & $6 \times 10^{-12}$ & $1 \times 10^{-4}$ & $2 \times 10^{-13}$ & $4 \times 10^{-6}$ \\
\hline & & 1 & $3 \times 10^{-10}$ & $3 \times 10^{-3}$ & $9 \times 10^{-12}$ & $9 \times 10^{-5}$ \\
\hline & Am 242 & $S$ & $4 \times 10^{-8}$ & $4 \times 10^{-3}$ & $1 \times 10^{-9}$ & $1 \times 10^{-4}$ \\
\hline & & 1 & $5 \times 10^{-8}$ & $4 \times 10^{-3}$ & $1 \times 10^{-9}$ & $1 \times 10^{-4}$ \\
\hline & Am 243 & 5 & $6 \times 10^{-12}$ & $1 \times 10^{-4}$ & $2 \times 10^{-13}$ & $4 \times 10^{-6}$ \\
\hline & & 1 & $1 \times 10^{-10}$ & $8 \times 10^{-4}$ & $4 \times 10^{-12}$ & $3 \times 10^{-5}$ \\
\hline & Am 244 & $s$ & $4 \times 10^{-6}$ & $1 \times 10^{-1}$ & $1 \times 10^{-7}$ & $5 \times 10^{-3}$ \\
\hline & & 1 & $2 \times 10^{-5}$ & $1 \times 10^{-1}$ & $8 \times 10^{-7}$ & $5 \times 10^{-3}$ \\
\hline
\end{tabular}

Berkelium Bk $249 \quad S \quad 9 \times 10^{-10} \quad 2 \times 10^{-2} \quad 3 \times 10^{-11} \quad 6 \times 10^{-4}$

\begin{tabular}{|c|c|c|c|c|c|}
\hline \multirow{3}{*}{$B k 250$} & 1 & $1 \times 10^{-7}$ & $2 \times 10^{-2}$ & $4 \times 10^{-9}$ & $6 \times 10^{-4}$ \\
\hline & $S$ & $1 \times 10^{-7}$ & $6 \times 10^{-3}$ & $5 \times 10^{-9}$ & $2 \times 10^{-4}$ \\
\hline & ! & $1 \times 10^{-6}$ & $6 \times 10^{-3}$ & $4 \times 10^{-8}$ & $2 \times 10^{-4}$ \\
\hline
\end{tabular}

\begin{tabular}{|c|c|c|c|c|c|c|}
\hline \multirow[t]{6}{*}{ Californium } & \multirow[t]{2}{*}{ Cf 249} & $S$ & $2 \times 10^{-12}$ & $1 \times 10^{-4}$ & $5 \times 10^{-14}$ & $4 \times 10^{-3 i}$ \\
\hline & & 1 & $1 \times 10^{-10}$ & $7 \times 10^{-4}$ & $3 \times 10^{-12}$ & $2 \times 10^{-5}$ \\
\hline & \multirow[t]{2}{*}{ Cf 250} & $S$ & $5 \times 10^{-12}$ & $4 \times 10^{-4}$ & $2 \times 10^{-13}$ & $1 \times 10^{-5}$ \\
\hline & & 1 & $1 \times 10^{-10}$ & $7 \times 10^{-4}$ & $3 \times 10^{-12}$ & $3 \times 10^{-5}$ \\
\hline & \multirow[t]{2}{*}{ Cf 251} & $S$ & $2 \times 10^{-12}$ & $1 \times 10^{-4}$ & $6 \times 10^{-14}$ & $4 \times 10^{-6}$ \\
\hline & & 1 & $1 \times 10^{-10}$ & $8 \times 10^{-4}$ & $3 \times 10^{-12}$ & $3 \times 10^{-5}$ \\
\hline
\end{tabular}




\section{TABLE B-3}

\section{(CONT.)}

\section{RESTRICTED AREAS ${ }^{2}$}

AIR

IRU ELEMENT ISOTOPE ${ }^{\prime} \quad(\mu \mathrm{Ci} / \mathrm{m})$

Cf 252

$$
13 \times 10^{-11}
$$

Cf $25358 \times 10^{-10}$

$$
8 \times 10^{-10}
$$

Cf 25

.

Curium

$$
\mathrm{Cm} 242
$$

$1 \times 10^{-10}$

WATER

$\frac{(\mu \mathrm{Ci} / \mathrm{mi})}{2 \times 10^{-4}}$

AIR

( $\mu \mathrm{Ci} / \mathrm{mi})$

WATER

$2 \times 10^{-13}$

$(\mu \mathrm{Ci} / \mathrm{m})$

$2 \times 10^{-4}$

$1 \times 10^{-12}$

$7 \times 10^{-6}$

$4 \times 10^{-3}$

$4 \times 10^{-3}$

$3 \times 10^{-11}$

$7 \times 10^{-6}$

$5 \times 10^{-12}$

$4 \times 10^{-6}$

$3 \times 10^{-1}$

$1 \times 10^{-4}$

$$
5 \times 10^{-12}
$$

$4 \times 10^{-6}$

$2 \times 10^{-13}$

$2 \times 10^{-13}$

$1 \times 10^{-4}$

$2 \times 10^{-10}$

$7 \times 10^{-4}$

$7 \times 10^{-4}$

Cm 243

(

$6 \times 10^{-12}$

$1 \times 10^{-4}$

$1 \times 10^{-10}$

$7 \times 10^{-4}$

Cm 244

$9 \times 10^{-12}$

$2 \times 10^{-4}$

$$
1 \times 10^{-10}
$$

$8 \times 10^{-4}$

$\operatorname{Cm} 245 \quad 5 \quad 5 \times 10^{-12} \quad 1 \times 10^{-4}$

$$
1 \times 10^{-10}
$$

$8 \times 10^{-4}$

$\operatorname{Cm} 246 \mathrm{~S} \quad 5 \times 10^{-12}$

$1 \times 10^{-4}$

$$
1 \times 10^{-10}
$$

$8 \times 10^{-4}$

$\operatorname{Cm} 247 \quad 5 \quad 5 \times 10^{-12}$

$1 \times 10^{-4}$

$$
1 \times 10^{-10}
$$

$6 \times 10^{-4}$

$\operatorname{Cm} 248 \mathrm{~S} \quad 6 \times 10^{-13}$

$1 \times 10^{-5}$

$|x| 0^{-11}$

$4 \times 10^{-5}$

Cm $249 \quad 5 \quad 1 \times 10^{-5}$

$6 \times 10^{-2}$

$1 \times 10^{-5}$

$6 \times 10^{-2}$
$4 \times 10^{-12}$

$6 \times 10^{-12} \quad 2 \times 10^{-5}$

$2 \times 10^{-13} \quad 5 \times 10^{-6}$

$3 \times 10^{-13} \quad 7 \times 10^{-6}$

$3 \times 10^{-12} \quad 3 \times 10^{-5}$

$2 \times 10^{-13} \quad 4 \times 10^{-6}$

$4 \times 10^{-12} \quad 3 \times 10^{-5}$

$2 \times 10^{-13} \quad 4 \times 10^{-6}$

$4 \times 10^{-12} \quad 3 \times 10^{-5}$

$2 \times 10^{-13} \quad 4 \times 10^{-6}$

$4 \times 10^{-12} \quad 2 \times 10^{-5}$

$2 \times 10^{-14} \quad 4 \times 10^{-7}$

$4 \times 10^{-13} \quad 1 \times 10^{-6}$

$4 \times 10^{-7} \quad 2 \times 10^{-3}$

$4 \times 10^{-7} \quad 2 \times 10^{-3}$
$3 \times 10^{-12} \quad 2 \times 10^{-5}$ 


\section{TABLE B-3}

\section{(CONT.)}

\section{RESTRICTED AREAS ${ }^{2}$ UNRESTRICTED AREAS ${ }^{3}$}

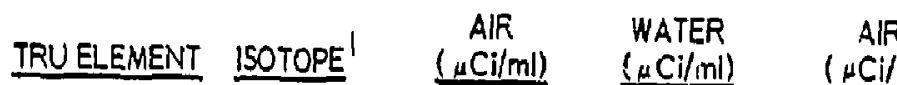

Einsteinium

Es $253 \quad s \quad 8 \times 10^{-10}$

$7 \times 10^{-4}$

WATER

$16 \times 10^{-10} \quad 7 \times 10^{-4}$

$3 \times 10^{-11} \quad 2 \times 10^{-5}$

$\begin{array}{llllll} & 1 & 6 \times 10^{-10} & 7 \times 10^{-4} & 2 \times 10^{-11} & 2 \times 10^{-5} \\ \text { Es } 254 m & 5 & 5 \times 10^{-9} & 5 \times 10^{-4} & 2 \times 10^{-10} & 2 \times 10^{-5} \\ & 1 & 6 \times 10^{-9} & 5 \times 10^{-4} & 2 \times 10^{-10} & 2 \times 10^{-5} \\ \text { Es } 254 & 5 & 2 \times 10^{-11} & 4 \times 10^{-4} & 6 \times 10^{-13} & 1 \times 10^{-5} \\ & 1 & 1 \times 10^{-10} & 4 \times 10^{-4} & 4 \times 10^{-12} & 1 \times 10^{-5} \\ \text { Es } 255 & s & 5 \times 10^{-10} & 8 \times 10^{-4} & 2 \times 10^{-11} & 3 \times 10^{-5} \\ & 1 & 4 \times 10^{-10} & 8 \times 10^{-4} & 1 \times 10^{-11} & 3 \times 10^{-5}\end{array}$

Fermium

$\begin{array}{llllll}F m 254 & s & 6 \times 10^{-8} & 4 \times 10^{-3} & 2 \times 10^{-9} & 1 \times 10^{-4} \\ & 1 & 7 \times 10^{-8} & 4 \times 10^{-3} & 2 \times 10^{-9} & 1 \times 10^{-4} \\ F m 255 & s & 2 \times 10^{-8} & 1 \times 10^{-3} & 6 \times 10^{-10} & 3 \times 10^{-5} \\ & \text { Fm 256 S } & 3 \times 10^{-8} & 1 \times 10^{-3} & 4 \times 10^{-10} & 3 \times 10^{-5} \\ & \text { s } & 3 \times 10^{-9} & 3 \times 10^{-5} & 1 \times 10^{-10} & 9 \times 10^{-7} \\ & 1 & 2 \times 10^{-9} & 3 \times 10^{-5} & 6 \times 10^{-11} & 9 \times 10^{-7}\end{array}$

Neptunium

Np 237 S $4 \times 10^{-12} \quad 9 \times 10^{-5}$

$\begin{array}{ll}1 \times 10^{-13} & 3 \times 10^{-6} \\ 4 \times 10^{-12} & 3 \times 10^{-5}\end{array}$

Np $23958 \times 10^{-7}$

$9 \times 10^{-4}$

$3 \times 10^{-8}$

$1 \times 10^{-4}$

$7 \times 10^{-7}$

$4 \times 10^{-3}$

$2 \times 10^{-8}$

$1 \times 10^{-4}$ 


\section{TABLE B-3}

\section{(CONT.)}

RESTRICTED AREAS ${ }^{2}$ UNRESTRICTED AREAS ${ }^{3}$

AIR WATER AIR WATER

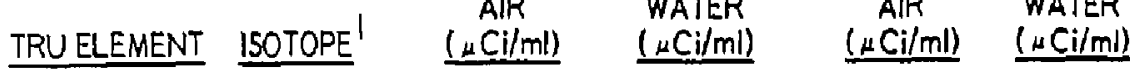

\begin{tabular}{|c|c|c|c|c|c|c|}
\hline \multirow[t]{14}{*}{ Plutoniun } & \multirow[t]{2}{*}{ Pu 238} & $S$ & $2 \times 10^{-12}$ & $1 \times 10^{-4}$ & $7 \times 10^{-14}$ & $5 \times 10^{-6}$ \\
\hline & & 1 & $3 \times 10^{-11}$ & $8 \times 10^{-4}$ & $1 \times 10^{-12}$ & $3 \times 10^{-5}$ \\
\hline & \multirow[t]{2}{*}{ Pu 239} & $S$ & $2 \times 10^{-12}$ & $1 \times 10^{-4}$ & $6 \times 10^{-14}$ & $5 \times 10^{-6}$ \\
\hline & & 1 & $4 \times 10^{-11}$ & $8 \times 10^{-4}$ & $1 \times 10^{-12}$ & $3 \times 10^{-5}$ \\
\hline & \multirow[t]{2}{*}{ Pu 240} & 5 & $2 \times 10^{-12}$ & $1 \times 10^{-4}$ & $6 \times 10^{-14}$ & $5 \times 10^{-5}$ \\
\hline & & 1 & $4 \times 10^{-11}$ & $8 \times 10^{-4}$ & $\mid \times 10^{-12}$ & $3 \times 10^{-5}$ \\
\hline & \multirow[t]{2}{*}{ Pu 241} & 5 & $9 \times 10^{-11}$ & $7 \times 10^{-3}$ & $3 \times 10^{-12}$ & $2 \times 10^{-4}$ \\
\hline & & 1 & $4 \times 10^{-8}$ & $4 \times 10^{-2}$ & $1 \times 10^{-9}$ & $1 \times 10^{-3}$ \\
\hline & \multirow[t]{2}{*}{ Pu 242} & $S$ & $2 \times 10^{-12}$ & $1 \times 10^{-4}$ & $6 \times 10^{-14}$ & $5 \times 10^{-6}$ \\
\hline & & 1 & $4 \times 10^{-11}$ & $9 \times 10^{-4}$ & $1 \times 10^{-12}$ & $3 \times 10^{-5}$ \\
\hline & \multirow[t]{2}{*}{$P \cup 243$} & 5 & $2 \times 10^{-6}$ & $1 \times 10^{-2}$ & $6 \times 10^{-8}$ & $3 \times 10^{-4}$ \\
\hline & & 1 & $2 \times 10^{-6}$ & $1 \times 10^{-2}$ & $8 \times 10^{-8}$ & $3 \times 10^{-4}$ \\
\hline & \multirow[t]{2}{*}{ Pu 244} & 5 & $2 \times 10^{-12}$ & $1 \times 10^{-4}$ & $6 \times 10^{-14}$ & $4 \times 10^{-6}$ \\
\hline & & 1 & $3 \times 10^{-11}$ & $3 \times 10^{-4}$ & $1 \times 10^{-12}$ & $1 \times 10^{-5}$ \\
\hline
\end{tabular}

$S=$ Soluble; $\quad I=$ insoluble

2 Restricted or eo is discussed in 10CFR Port 20.103

3 Unrestricted areo is discussed in IOCFR Part 20.105 
Of the 46 known isotopes of elements 93 (Np) through 99 (Es) with half-lives greoter than one doy, 30 ore alpha emitters, nine decoy by beto emission, five capture orbital electrons, and two undergo spontaneous fission as the primary modes of decoy. Several of these rodionuclides, however, ore parents of decay chains whose various decoy products have half-lives which cause o complicated pottern of growth and decoy of daughter products after the initiol preparation of an isolated and essentially pure radionuclide. The precursors from irradiation miay also exist in a given sample, as a result of incomplete separation, and add to the complex decoy chain.

If the half-life of the "parent" tronsuranic radionuclide is much longer then that of the "doughter" (e.g. Am-243-Np-239, Cm-245-Pu-241, or Es-254-Bk-250), the octivity of the material handled will opproach the state of secular equilibrium in which the number of daughter otoms formed per unit time is equal to the number which decoy. The rote of opproach to this steady stote is governed by the holflife of the daughter os $\left(1-\mathrm{e}^{-} \lambda^{\dagger}\right)$, No equilibrium exists if the doughter is longer lived than the porent (e.g. Am-241-No-237, Cm-244-Pu-240 or C $-252-\mathrm{Cm}-248$ ). These two conditions--secular and no equilibrium--prevail; transient equilibrium, which requires the parent and doughter to hove approximately equal half-lives, seldom occurs in the transuranium decay schemes.

\section{jpecific Activity}

The relatively short half-lives of many of these radionuclides leads to a high specific activity, i.e. o large number of curies per gram of nuclide. The halflife, specific octivity and an activity cumparison normalized to Pu-239 are shown in Table B-4.

When one recalls that Pu-239 hos o specific octivity some $10^{5}$ times that of nctural uranium, the rapid decay rates for the tronsuranium radionuclides are clear. The radius of spherical particles of the mere common transuranium rodionuclides that would decay at the rote of $1000 \mathrm{~d} / \mathrm{m}-\mathrm{a}$ contarnination level at which it is necessary to consider the need for decontamination, ranges from obout $10^{-4}$ to about $10^{-5} \mathrm{~cm}$. It is necessary to consider the degree of control 


\section{TABLE B-5}

\section{RADIOACTIVE DECAY \\ AND SPONTANEOUS FISSION HALF-LIVES \\ OF SELECTED NUCLIDES}

\begin{tabular}{|c|c|c|c|c|c|}
\hline Isotope & $\begin{array}{c}\text { Rodioactive } \\
\text { half-life } \\
\text { (vr) } \\
\end{array}$ & $\begin{array}{l}\text { Specific } \\
\text { octivity } \\
\text { (Ci/o) }\end{array}$ & $\begin{array}{l}\text { Normalized } \\
\text { to Pu-239 }\end{array}$ & $\begin{array}{c}\text { Spontoneous } \\
\text { fission } \\
\text { half-life } \\
(y r) \\
\end{array}$ & $\begin{array}{c}\text { Calculated } \\
\text { neutron emission } \\
\text { rate } \\
\text { (n/secla) } \\
\end{array}$ \\
\hline $\mathrm{Pu}-239$ & 24,400 & 0.062 & 1 & $5.5 \times 10^{15}$ & 0.03 \\
\hline Am-243 & 7,950 & 0.185 & 3 & .. & -- \\
\hline Am-24I & 458 & 3.24 & 52 & $2 \times 10^{14}$ & 0.06 \\
\hline Pu-238 & 86.4 & 17.6 & 280 & $4.9 \times 10^{10}$ & $3.4 \times 10^{3}$ \\
\hline $\mathrm{Cm}-244$ & 17.6 & 83.3 & 1,300 & $1.3 \times 10^{7}$ & $1.2 \times 10^{7}$ \\
\hline $\mathrm{Pu}-241^{*}$ & 13.2 & 113 & 1,800 & -- & -- \\
\hline $\mathrm{Cl}-252$ & 2.646 & $\$ 36$ & 8,600 & 85 & $2.3 \times 10^{12}$ \\
\hline$B k-249^{*}$ & 0.86 & 1,680 & 27,000 & $6 \times 10^{8}$ & $2.7 \times 10^{5}$ \\
\hline Es-254 & 0.756 & 1,870 & 30,000 & $7 \times 10^{5}$ & $2.9 \times 10^{8}$ \\
\hline
\end{tabular}


required to avoid the loss of control of even one porticle of these small sizes and the contoinment problems for hondling these radiontclides.

The high specific activities also lead to higher dose rates for small quantities of moterials if one is meosuring quantity in units of weight. For all of these nuclides it is necessary to be olert to the potential for X-roy and gamma-ray rodiations as well os neutron ond beta rodiotions, even though the primary mode of decay may be by alpho particle emission.

\section{Spontaneous Fission}

Spontaneous fiswon of transuranium radionuclides results in the emission of many neutrons in addition to the build-up of fissian products that emit both beto and gamma rays. Some of the transuranium radionuclides have relatively short spontoneous fission half-lives corresponding to high spontaneous fission decoy rotes. In fact, the very high spontaneous fission rate of $\mathrm{Cf}-252$ hos provided a most useful application of this radionuclide as a neutron source. It has unique potentials becouse it provides a small source of on intense neutron flux. Table B-2 summarizes the spontaneous fission half-lives ond neutron emission rotes for some of these rodionuclides.

\section{CHEMICAL PROPERTIES}

The chemical reactions of the transuranium radionuclides are similar to and may be expected to generally porallel the reactions of plutonium: there are, of course, many specific exceptions to their plutonium-like chemical behovior. The chemical reactions of plutonium have been extensively studied ard several good reviews and handbooks summarizing these properties are readily available. For example, the two volume Plutonium Handbook edited by Wick details the chemical as well as physical properties of plutonium.

The transuranium radionuclides are metals, although with the exception of plutonium, americium and neptunium, they are seldom ovoilable in quantities sufficient for visual recognition as metals. These radionuclides, as finely divided 
metals, are pyrophoric--reocting ropidly with oxygen to form oxides. They are best stored and handled in inert atmospheres until reacted to form some stable compound. In many of their chemical compounds they may be in a powder form and ecsily dispersed. The minute porticles thot may breok or be rubbed off of even large crystal forms lead to challenging handling and contoinment programs if rigid control over these materials is to be established and maintained.

The high specific activity of the transuranium rodionuclides leads to handling difficulites other than contamination contral. Self-heating, adiolytic decomposition actions in aqueous solution, and spontaneous ignition when exposed to air (oxygen) constitute the bulk of these problems. A kilogram of plutonium metal is warm to the touch, emitting $\sim 2$ watts of thermal energy, while $\mathrm{Cm}-244$ and $\mathrm{Cm}-242$, potential thermoelectric power sources, emit approximately 3 and 120 wattsig of thermal energy, respectively, In most applications only Pu-238, Cm242, $\mathrm{Cm}-244$ and $\mathrm{Cf}-252$ produce sufficient heat to be of concern. Table B-5 summarizes the decay heat production of some transuranium radionuclides.

The chemical form of a transuranium radionuclide can change 'the magnitude and nature of the radiation hazards encountered. The high energy alpho emissions con result in an alpho particle nuclear reaction which can result in significant neutron emissions (e.g, beryllium, oxygen, chlorine, fluorine and nitrogen chemical reactions involving transuranium radionuclides may tronsform a sofely shielded facility designed for alpho and low-energy photon rodiations into a poorly shielded facility where neutron rodiation becomes of primary concern).

\section{CRITICALITY CONSIDERATIONS}

The potential for a self-sustaining nuclear chain reaction of criticality accident is currently not as significant for the transplutonium elements as for Pu-239 or U-235 becouse of the limited (generolly less than $100 \mathrm{~g}$ ) amounts of these materials ovailuble at any given facility. If quantities of any transuranium radionuclide greater than 300 grams are ovailable, a careful and detailed review of criticality control provision is mandatory. Only a few transplutonic nuclides appear to be capable of supporting a chain reaction with thermol ncitrons; the 
TABLE B-5

DECAY HEAT PRODUCTION

Nuclide

Decoy Heot,

Nuclide

Watts/g

Pu-238

0.57

Pu-239

0.0019

Pu-240

0.014

Pu-241

0.00011

$A m-241$

0.11

Am-243

0.0061

Cm-242

120

Cm-244

2.8

$8 k-249$

0.4

Cf-252

39

B- 14 
remainder are fissioncble by fast neutrons only (os metals or alloys). The fissile nuclides in salution present the most seriaus criticality control problems since the amount of material in solution is difficult to inventory and the critical mass is usually lower for solutions than for metals.

Table B-6 compares the neutron cross-sections and the number of neutrons emitted per fission event of severol tronsplutonic nuclides with those of the more familiar fissile materials, U-233, U-235, and Pu-239. 


\section{TABLE B-6}

NEUTRON CRITICALITY PARAMETERS

\begin{tabular}{lcccc} 
Nuclide & $q^{\text {(born) }}$ & $\underline{q^{\text {(barn) }}}$ & $\begin{array}{c}\text { neutrons/ } \\
\text { fission }\end{array}$ & $\begin{array}{c}\text { Minimum } \\
\text { criticol } \\
\text { moss* } \\
\text { (g) }\end{array}$ \\
\cline { 2 - 3 } & 49 & 524 & 2.50 & 590 \\
U-235 & 99 & 579 & 2.43 & 820 \\
Pu-239 & 254 & 754 & 2.89 & 510 \\
Am-242m & 5500 & 6390 & $\sim 3.0$ & 1000 \\
Cm-243 & 250 & 590 & $\sim 3.2$ & $500-1000$ \\
Cm-245 & 335 & 1900 & $\sim 3.2$ & 500 \\
Cm-247 & 180 & 1026 & $\sim 3.3$ & 500 \\
Cf-249 & 270 & 630 & $\sim 3.7$ & $500-1000$ \\
Cf-251 & 1100 & 3000 & $\sim 3.7$ & $500-1000$ \\
Es-254 & 40 & 2000 & $\sim 3.9$ & 500
\end{tabular}

*Minimum critical mass for fully reflected solutions. 


\section{APPENDIX C}

WIPP ACCEPTANCE CRITERIA FOR

DEFENSE LOW-LEVEL TRU WASTE ${ }^{38,39,40}$ 


\section{Appendix $C$}

WIPP ACCEPTANCE CRITERIA FOR

DEFENSE LOW-LEVEL TRU WASTE $38,39,40$

\subsection{INTRODUCTION}

The following is the verbatim text of the "WIPP Acceptance Criteria for Defense Low-Level TRU Wasie, July 1, 1977." These are draft criteria for waste acceptance at the Waste Isolation Pilot Plant (WIPP), a proposed Federal repository. Although the criteria are subject to change, they are presented here as background material to amplify the processing discussions in the present report, Indeed, in the recent Draft EIS on the WIPP facility ${ }^{39}$ modifications were made and are included herein.

\subsection{WIPP ACCEPTANCE CRITERIA}

FOR

DEFENSE LOW-LEVEL TRU WASTE

$$
\text { (July 1, 1977) }
$$

This document delineates the acceptance criteria proposed for defense low-level TRU waste received for storage at the Waste Isolation Pilot Plant (WIPP). By intent-and by ERDA directive--these criteria are conservative; it is likely that future changes in the criteria will be in the direction of less restrictive specifications. Changes will be made only when they can be justified on the basis of more complete knowledge of the behavior of the sait storage medium and of the waste material itself. "Final" pre-ope:ational criteria will probably not be available before July, 1979.

In this document, "TRU waste" refers specifically to the solid radioactive waste described in ERDA Manual Appendix 0511, Part I, paragraphs 8-i8, 22, and 23 (interpreted here to include Pu-238, but not Pu-241, among the transuranic isotopes). "Low-level" refers to waste packages which exhibit surface dose rates no greater than $500 \mathrm{mrem} /$ hour, as defined in Chopter 20 of ERDA-76-43 (TAD).

The present criteria have evolved from eariier drafts through numerous reviews by most of the agencies involved in the management of ERDA-generated radioactive wastes; the contribution of these agencies is gratefully acknowledged. 


\section{DEFINITIONS}

Low-Level TRU Waste: Any solid waste material, other than highlevel waste, which is contaninated with long-lived alpha enitters to the extent that, under the provisions of ERDA Manual Chapter 0511, it is not suitable for surface burial, but which exhibits sufficiently low radiation leveis (surface dose rate levels $\leq 500 \mathrm{mrem} / \mathrm{hr}$ ) that it is amenable to handling by "contact" (as opposed to "remote") methods.

Haste Containar: The box or drum, including any associated liner and/or shielding material, which inmediately surrounds (and is considered to be an integral, oisposatle part of) the waste material.

Waste Package: The final configuration of the waste in its container, ready for emplacement in a suitably prepared storage site.

Overpack: A second layer of containment whith may be required (and applied) by the WIPP operator because of the mechanica) condition or level of surface contamination of the waste container.

Combustible Materials: Materials which will sustain combustion when exposed to a temperature of $1300^{\circ} \mathrm{F}\left(700^{\circ} \mathrm{C}\right)$ for a period of 15 liinutes or less, in atmosphere air. (Examples of combustible matertals are paper, most piastics, eloth, and wood.)

fas-Producing Materials: Materfais which prosuce gas during thetr decomposition by radiolysis, pyrolysis, chemical reaction, or bacter Ia) decay. (Gas-producing materials include virtually all combustibles and such non-combustibles as concrete, stee?, and certain process sludges.) 


\section{ACCEPTANCE CRITERIA}

It is axiomatic that no acceptance eriteria document can adequately address all the special cases which may arise in the management of defense low-level TRU waste. The WIPP operator will cooperata with waste generating agencius in formulating waste treatment and packaging procedures which bring special waste forms into compliance with the spirit, if not the letter, of these criteria.

A. WASTE FORM

1. Combustible Materials: The shipment of low level TRU waste to the WIPP will be coordinated on an ERDA-wide basis so that the total amount of combustible material in a single storage room does not exceed 20 percent by volume (but Section Ii.A.2 also applies). In the content of this criterion, the materials used in the fabrication of DOT-7A and similar non-metal containers is considered to be combustible.

When necessary to meet this specification, combustible waste will be incinerated or digested, using technology current at the time of processing, to convert the combustibles to a chemically stable form.

In order to control the radiolytic production of flamable gases, the TRU nuclide content of unprocessed combustible waste is $1 \mathrm{im-}$ ited to $2 \mathrm{Ci} / \mathrm{ft}^{3}\left(70 \mathrm{ci} / \mathrm{m}^{3}\right)$ of alpha emitters.

2. Gas-Producing Material: The shipment of low-level TRU waste to the WIPP will be coordinated on an ERDA-wide bas is so that the total amount of combustible and gas-producing materials in a single storage room does not exceed 10 percent by weight. In the context of this criterion, the materials used in the fabrication of all present containers and liners are considered to be gas-producing. 
3. Explosive and Pyrophoric Materials: Waste containing explosive or pyrophoric materials will not be accepted for stordge at the HiPP.

4. Toxic Materials: Packages containing waste whose constituents are known to produce toxic fumes (e.g., by thermal decomposition or chemical reaction with other materials in the same container) when exposed to fire temperatures up to $1300^{\circ} \mathrm{F}$ $\left(700^{\circ} \mathrm{C}\right)$ will be prominently labeled in a manner prescribed by the WIPp operator. The term "toxic fumes" refers to gases and vapors of moderate and severe toxicity, as defined in Section 9 of "Dangerous Properties of Industrial Materials, "Library of Congress Catalog Card Number 74-17275.

5. Liquids: Waste containing free liquids will not be accepted for storage at the WIPP. Process sludges must either be dried by heating or mixed homogeneously with an appropriate drying agent; in either case, the liquid content of the product should be controlled to minimize dispersal of the waste in a handling accident.

6. Stabilization: Finely divided waste forms such as incinerator residues will be stabilized in concrete or glass (or such other matrices as may be approved by the WIPP operator), or pelletized, in such a manner as to minimize the production of respirable fines in a handling accident.

7. Thermal Power Density: Individual low-level TRU waste packages in which the average thermal power density exceeds 0.1 watt $/ \mathrm{ft}^{3}\left(3.5\right.$ watts $\left./ \mathrm{m}^{3}\right)$ will be prominently labeled in a manner prescribed by the WIPP operator.

8. Nuclear Criticality: The fissile isotope content of low-level TRU waste is 1 imited to the values specified in DOT Exemption Ho. 5948: $200 \mathrm{~g}$ of fissile isotope per 55-gallon (210-1iter) or larger drum, $100 \mathrm{~g}$ per 30-gallon (115-1iter) drum, 
and $6 \mathrm{~g} / \mathrm{ft}^{3}\left(200 \mathrm{~g} / \mathrm{m}^{3}\right)$ in boxes. (Hote that Section II.A.7 Iimits the concentration of heat source plutonium to about $1 \mathrm{~g}$ per 55-galion drum, $0.5 \mathrm{~g}$ per 30 -gailon drum, and $0.2{\mathrm{~g} / \mathrm{ft}^{3}}^{3}$ $\left(6 \mathrm{~g} / \mathrm{m}^{3}\right)$ in boxes.)

\section{B. WASTE CONTAINER}

1. Dimensions: The largest waste container which can be accomodated inside the WIPP low-level hoist cage ie 8 feet $x$ 12 feet $\times 9$ feet high $(2.4 \mathrm{~m} \times 3.7 \mathrm{~m} \times 2.7 \mathrm{~m}$ high $)$, including handling appurtenances. The use of waste containers smaller than the DOT 17C 55-gallon (210-1iter) drum is discouraged but not prohibited.

2. Handling Appurtenances: All low-level TRU waste containers must be provided with cleats, offsets or chines which permit handling by means of fork trucks. Lifting rings and similar handling devices are permissible provided they are recessed or hinged in a manner wich permits stacking in a close array.

3. Materials of Construction: iletal containers are preferred; wooden and plastic containers are permitted. In all cases, the materials used in the fabrication of waste containers are subject to the limitations for combustible and gas-producing materials defined in Sections II,A.I and II.A.2.

4. Structural Design: The structural design of all lowlevel TRU waste containers must meet the requirements for Type $A$ packages as outlined in 49CFR $173.398 \mathrm{~b}$ and, in addition, must permit the stacking of fully loaded containers on an empty container of the same type, to an overall height of $12 \mathrm{ft}(3.7 \mathrm{~m})$.

5. Liners: The use of drum or box liners is permitted when required because of the physicai or chemical properties of the contained waste material. When used, the liners should be made 
of materials wich mininize the rate and total quantity of gas produced is a result of radiolytic, pyrolyt is and bacterial decomposition; Sections II,A,I and II,A.2, Miniting the use of combustible and gas-producing materials, upply to liner materials. The use of halogenated plastics such as PVC is discouraged but not prohtbited.

\section{WASTE PACKAGE.}

1. Neight: The weight of a single low-level TRU waste package is limited to 25,000 pounds $(11400 \mathrm{~kg})$, the capacity of the WIPP low-level noist.

2. Surface Contamination: The maximum permissible levels of loose plus fixed surface contanination (above which the waste package will be decontaminated or overpacked at the expense of the shipper) are as specified in 49CFR 173.397:

\section{Contaninant}

Matural or depleted uranium and natural thorium:

$\begin{array}{lll}B-Y & 10^{-3} & 2200 \\ a & 10^{-4} & 220\end{array}$

All other $B-Y$ enitting radionuclides

$10^{-4}$

220

All other a enitting radionuclides
Maximum Permissible Loose Plus Fixed Contamination Level

$$
\underline{\mu C i / c m^{2}} \quad \text { dis/min-cme }
$$


An additional limit applies to agencles wich generate more than $5000 \mathrm{ft}^{3}\left(140 \mathrm{~m}^{3}\right)$ of low-level TRU waste per year: averaged over the kaste packages shipped in a given quarter, the surface dose rate may not exceed $10 \mathrm{mrem} / \mathrm{hour}$.

4. Labeling: Each waste package will be uniquely identified by means of a label which is permanently attached to the container in conspicuous location. Information obtainable from the label itself and from the records pertinent to the waste package will include the following:

Label

- Package identification number (to be standardized)

- Haste generating agency

- Date of packaging

- Radiation levels: mrem/hour of neutrons and gammas, at the surface and at a point 1 in from the surface

- Weight (in pounds and $\mathrm{kg}$ )

\section{APPENDIX: RATIONALE FOR ACCEPTANCE CRITERIA}

A. NASTE FORH

1. Combustible Materials: The permiss ible volume percent of combustible is derived as follows:

Assumptions

a. A a ft $\times 4 \mathrm{ft} \times 7 \mathrm{ft}$ plywood box contains $350 \mathrm{~g}$ (148 Ci) of plutonium. 
b. The fractional airborne release due to burning contaminated waste is $0.05 \%$ (PNWL-B-27L).

c. The airflow through repository room is $17 \mathrm{~m}^{3} / \mathrm{sec}$.

d. A fire is initiated by the detonator of explosive gases, with rupture of the associated boxes.

e. The burning time of a single box is 30 minutes. This corresponds to a fire propagation rate of $0.07 \mathrm{~cm} / \mathrm{sec}$, a value which is consistent with experimentaliy determined rates.

f. The maximum permissible body burden for plutonium is between $0.04 \times 10^{-6}$ and $0.1 \times 10^{-6} \mathrm{C}$, depending on the date of publication.

g. The human breathing rate is $3.47 \times 10^{-4} \mathrm{~m}^{3} / \mathrm{sec}$.

(a) and (b) imply that a box releases $0.074 \mathrm{Ci}$ (at a rate of $4 x$ $10^{-5} \mathrm{Ci} / \mathrm{sec}$ in a 30 -minute fire).

From (c), the air activity is $2.4 \times 10^{-6} \mathrm{ci} / \mathrm{m}^{3}$.

From $(g)$, the exposure rate is $8.3 \times 10^{-10}=10^{-9} \mathrm{Ci} / \mathrm{sec}$.

From ( $f)$, the time to reach maximum permissible body burden is from 40 to 100 seconds (about 1 to 2 minutes, a reasonable time for an individual downstrean from the fire to isolate himse if from the hazardous environment).

In order to contain the fire and reduce its impact on associated boxes, the combustible boxes are stacked among non-combustible boxes in an array which isolates the combust tbles (storage rooms are designed for a 3-high stacking): 


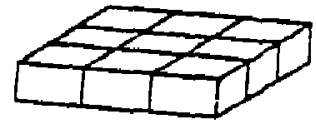

Top Layer

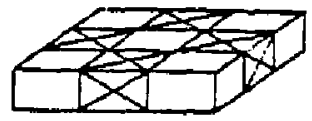

Middle Layer

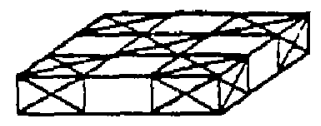

Bottom Layer $x$ denotes combustible hoxes

In this array, $9 / 27=33 \%$ of the boxes can be combustible

Corner contact allowed, no combustibles in top laver

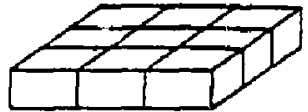

Top Layer $x$ denotes combustible hoxes 
Middle Laver

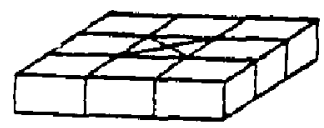

Bottom Layer

For conservatism, the corner-contact array is chosen; the oermis sinle percent of combustibles is $220 \%$.

The allowable fraction of combust ibles is exoressed as a volume percent, rather than as a weicht percent, to emphasize the importance of trash compaction; this reduces the fire h.jzard and at the same time saves storage volume.

LASL experiments have shown that furing the 20-50 years of active WiPP operation, hydregen generation from the radiolys is of combustibles can be helo to a non-hazardous level by limiting the alpha activity of conthustible TRU waste to ? Ci/ft ${ }^{3}$.

2. Gas-Producing Materiais: This criterion is predicated on the desire to control pressurization of the (decomissioned) repository due to long-term gas build-up. The undergrnund openings are expected to close by salt creep in a oeriod from 200-2000 years, a time which is shart comparon with the time during which gas wil? he produced in radiolytic, ovrolytic, chemical, and bacterial processes. The gas permeability of the salt formation is presently unknown, but is estimated to be small 
enough to allow significant accumulation of gas. Gas pressure may cause some rewinflation of the underground workings. The amount of re-inflation which can occur before gas fracture of the geologic formation results is an open question. It is not clear that this essentially hydrostatic environment would not allow sufficient plastic flow to accommodate whatever gas is produced. Current thinking, however, is that less than 10 percent reinflation may cause gas fracture of the waste storage horizon.

If total gas generation can be shown experimentally to be low enough and/or if the gas permeability of the salt medium is found to be high enough, then the permissible amount of gas-generating materials can be revised upward from the present conservative value.

Estimation of gas leakage, using the calculations of Cheverton, Claiborne and Evans (ORNL-TM-4569), suggest that the salt has a permeability coefficient which is sufficiently low that a substantial anount of gas will be retained. Laboratory and in situ measurement of salt permeability is a first-priority requirement; this has been initiated at Sandia Laboratories.

\section{Assumptions}

a. Volume of storage room plus associated tunnel $=2 x$ $(356,400) \mathrm{ft}^{3}$.

b. Volume of orums in storage room $=92,400 \mathrm{ft}^{3}$.

c. Volume of void space to be backfilled with crushed salt $=264,000 \mathrm{ft}^{3}$.

d. Volume of tunnel to be backfilled with crushed salt = $356,400 \mathrm{ft}^{3}$. 
e. Total initial vold volume - void space in backfilled salt in storage room and tunnel + one-half volume of drums.

f. Nitrogen in nine contributes $2 \times 10^{5}$ roles of $\mathrm{N}_{2}$.

g. Gas production (other than $\mathrm{H}_{2}$ produced by corrosion of steel)--i.e., the capacity of the trash to produce gas--is $450 \mathrm{~m}^{3}$ (STP)/ $1000 \mathrm{~kg} / 02 \%$ $10^{4}$ moles $/ 1000 \mathrm{~kg}$ ).

h. $P V=\sum n_{i} R \bar{T}$

i. Gas temperature $=40^{\circ} \mathrm{C}$.

The number of metric tons of gas-producing waste required to fill the available void space with gas at hydrostatic pressure (82 bar') and lithostatic pressure (152 bars) a $a^{x}$ e tabulated below for backfill densities of $50 \%$ and $80 \%$.

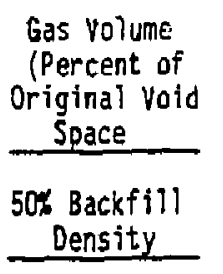

100

50

25

10

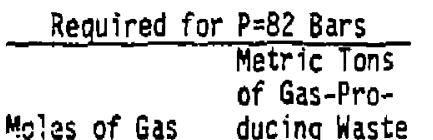

Molas of Gas $\frac{\text { Required for } P=152 \text { Bars }}{\text { Metric Tons }}$

Moles of Gas ducing Waste

80\% Backfill

Density

$\begin{array}{rrrrr}100 & 1.53 \times 10^{7} & 765 & 2.8 \times 197 & 1420 \\ 50 & 7.6 \times 10^{6} & 382 & 1.4 \times 10^{7} & 710 \\ 25 & 3.8 \times 10^{6} & 197 & 7 \times 10^{6} & 355 \\ 10 & 1.5 \times 10^{6} & 76.5 & 2.8 \times 10^{6} & 142\end{array}$


For re-infiation of the mine to 10 percent of the original void volume, the amount of gas-producing waste required to produce a gas pressure of 152 bars (with a backfill density of 50 percent) is 150 metric tons. This is equivalent to about 100055 -gallon drums ( $150 \mathrm{~kg}$ per drum)--or $8(=10)$ percent by weight of the total room capacity.

3. Explosive and Pyrophoric Materials: A recent survey by Mouno Laboratory indicates that no ERDA agency contemplates shipping explosive or pyrophoric wastes for storage at the WIPp. Therefore, the categorical exclusion of such materials causes no immediate inconvenience for the waste generators, and it assures proper planning to avoid possible future conflitts with this eriterion.

4. Toxic Materials: This criterion does not bar material having a potential for producing toxic fumes in a fire environment; it merely assures that the WIPP operator will be ak'are of the presence of such materials, so that he can take extra precautions against exposure of that waste to high temperature.

5. Liquids: The intention here is to allow a waste generator to exercise his judgement as to how much liquid to leave in the final waste form. From the standpoint of the long-term safety of the WIPP, it is clearly desirable to leave as little liquid as possible in the waste: the liquid can serve as both a leaching agent and a transport medium. On the other hand, a crmpletely dewatered and otherwise unstabilized sludge would release an unacceptably and unnecessarily large anount of fines in a handling accident. As a guideline, it is observed that the new Waste Treatment facility at Rocky Flats will reduce sludges to a pelletized form containing 5 to 10 percent sorbed water. 
6. Stabilization: This specification has both short-and long-term safety implications. The short-term concern is, again, the release of fines in a handling accident. The long-term concern is the leachability of the waste form; this is taking on a greater and greater importance in Sandia's risk assessment activities. Unfortunately, present technology will not support a meaningful specification for leachability, but it should not be dismissed as an abjective. By way of providing reassurance to waste generators, it is pointed out that, from the standpoint of leachability, ordinary concrete is probably adequate as a stabilizing matrix; glass is better, and recent work at Rocky Flats indicates that "glassification" of incinerator residues is feasible both technologically and economically.

7. Thermal Power Density: This criterion is based on the power density corresponding to 200 grams of weapons-grade plutonium (or 1 gram of heat source plutonium) in a 55-gal drum containing $6 \mathrm{ft}^{3}$ of waste. The interest is in identifying especially "hot" waste packages so that they can be stored among packages which contain relatively little combustible and gasproducing material. Thermal considerations in the WIPP do not impose a readily identifiable limit on power density; in a practical sense, the upper limit is determined by shipping regulations and the economics of plutonium recovery.

8. Nuclear Criticality: Shipping regulations (specifically, DOT Exemption No. 5948) alone are sufficient to prevent criticality incidents in the HIPP.-unless there is dissolution and reconcentration of the fissile species. This is a highly improbable scenario, but one whose importance cannot be evaluated until more sophisticated nuclide transport codes are availabie. 


\section{B. WASTE CONTAINER}

1. Dimensions: Except for a few very large items of decomimissioning waste, container sizes will never approach the $8 \mathrm{ft} x$ $12 \mathrm{ft} \times 9 \mathrm{ft}$ limit imposed by the size of the HIPP low-level TRU waste hoist cage. As a rare perturbation of normal operating procedures, it may be posstble to rig very large items below the hoist cage.

2. Handling Appurtenancf:: The justification for this specification is self-evident.

3. Materials of Construction: All container materials of practical interest are potential gas producers; metal is the least objectionabie from this standpoint. Rocky Flats is not considering the use of an all-Fiberglass box; LASL suggests that the Fiberglass (actually, Fiberglass-reinforced polyester) should be treated with antimony oxide as a fire retardant, Any container material is acceptable, as long as the conditions of Sections II.A.I and II.A.2 are satisfied.

4. Structural Design: At a June 2, 1977, meeting at Mound Laboratory, representatives of Mound, LASL ARHCO (for OWI) and Sandia concluded that there is no need for the structural design of TRU waste containers to exceed the requirements of $49 \mathrm{CFR}$.

5. Liners: The position taken in these criteria is that ihe decision to use or not to use a liner should rest with the vaste generator. There is no requirement for container integrity beyond the time of emplacement in tue storage rooms, but survival of packages containing unneutralized acids or bases for even that long might well depend on the use of a liner. Alternatively, the waste generator might choose to neutralize the acid or base before drying or sorbing it, and omit the liner. 


\section{WASTE PACKAGE}

1. Weight: The capacity of the WIPP low-level TRU waste hoist is 25,000 pounds--a value uetermined on the bas is of Sandia's best engineering judgement. Surface and underground handling equipment is designed to handle single 25,000-pound waste pac. dge.

2. Surface Contamination: The WIPP plan to inspect incoming waste packages by automated direct alpha counting makes it impossible to distinguish between fixed and removable surface contamination. Admittedly, if all waste packages arrived with maximum perrisssible contamination levels, and if all the surface contamination were removable, there could be a serious airborne contamination problem throughout the WIPP low-level TRU waste facility. Historically, this has not happened, and the fact that the WIPP is prepared to accomodate occasional (relatively) nighly contaminated waste packages will not provide an incentive for waste generators to aiter their present practices.

3. Penetrating Radiation: The major producers of defense TRU waste have indicated that there is a very real advantage, in terms of processing and packaging requirements, in treating packages with surface dose rates up to $500 \mathrm{mrem} / \mathrm{hr}$ as "low-level" waste. Records shows that there will be relatively few such packages, and that a great majority of the packages will exhibit surface dose rates less than the $10 \mathrm{mrem} / \mathrm{hr}$ value used as the basis for the WIPP design. Automated inspection equipment will divert "hot" packages for special handling, so that no serious perturbation of routing operation is anticipated.

4. Labeling: Labeling requirements witl be more fully developed in consultation with the waste generators. There is no intention to place an unnecessary burden on shippers, but it is 
considered important to be able to distinguish power reactor fuel reprocessing waste, for example, from weapons program waste. It is likely that a coding system similar (or identical) to that in use at INEL will be adoped.

5. Color Coding: Again, further development work is necessary. As noted in the criterion itself, the color-coding system will be compatible with systems already in use, and should not pose a serious problem for waste shippers. 


\subsection{INTERIM WIPP ACCEPTANCE CRITERIA ${ }^{39}$}

This section describes the interim criteria for accepting the wastes that will be stored of the WIPP reference repository.

\subsection{WASTE-ACCEPTANCE CRITERIA}

In 1977, the U.S. Deportment of Energy (DOE) formed the Woste Acceptance Criteria Steering Committee (WACSC). The Committee initially consisted of technical personnel from DOE headquarters, DOE field offices controlling defense wastes, the Office of Waste Isolation, and the WIPP staff from Sandia Laborotories. The Committee has since been expanded to include representotives from the Rocky Flats Plant, the Office of Nuclear Waste Isolation, and the Westinghouse Electric Corporation (the WIPP technical-support contractor). 39,38

The WACSC reconciles the interests of various agencies involved with the production, treatment, and disposal of defense TRU wastes. Its ultimate goal is to formulate workable, practical criteria for the acceptance of these wostes. Data for quantifying the criteria are being developed in research and development progroms at various DOE laboratories. The criterio are constantly evolving and, as described below, reflect only interim proposals. ${ }^{39}$

\subsubsection{DEFINITIONS}

Discussions of waste-acceptance criterio frequently use several terms thot need to be clearly defined: container, package, overpack, combustible material, gosproducing material, and immobilized material. Eoch is defined below occording to its accepted meaning in this section. These are not official definitions, rather, they are abstracted versicis of the officiol definitions; they convey concepts and avoid specific detail.

Container: A drum, box, or canister that immediately surrounds the waste is the waste container. Any associated hardware such as liner moterial or spiders for spacing is considered port of the container. 
Package: Once woste is ploced inside the container, the container becomes an integral port of the waste. The waste and its container are colled the woste pockoge. It is the pockoge that is emplaces in the repository.

Overpack: If required by the physical condition of the container or by the surface-contamination levels, a supplementary loyer of contoinment is placed over the originol container and is then considered to be part of the woste package. The supplementory containment is the overpack.

Combustible material: Any moterial that will sustain combustion in air at a temperature of $802{ }^{\circ} \mathrm{C}$ for a period of 5 minutes is combustible.

Gas-producing moterial: Any ---terial that praduces gos during its decomposition is gos-producing. Many .. nterials, porticularly organic materials, produce hydrogen, methane, corbon monoxide and carbon dioxide by radiolytic decomposition, pyrolysis, chemical reaction (corrosion), and/or bacterial decamposition. The salt formation at the reference site has a very low permeability for these gases, and the potential moy exist for producing gos pressures high enough to disrupt the rock formations immediately surrounding the repository. The rotes of gas production by the various mechonisms and the permeability of the salt formation are now being studied.

Immobilized material: Any material, excluding liquids, that contains less than I percent (by weight) of powder (less than or equal to 10 microns in size) is considered immobilized. The intent of immobilization is to minimize the amount of respirable material in the waste packages.

\subsubsection{TRANSURANIC WASTE}

Transuranic waste is cotegorized in two closses: contact-handled $(\mathrm{CH})$ and remotely-handled (RH). A qualitative distinction between contact-hondled and remotely-handled "RU woste is made in this document: contact-handled woste emits so little rodiation that workers can handle it without extensive shielding; remotely-handled waste requires shielding and/or remote hondling to protect operating personnel. The criterion designates waste packages with surface-dase rates no higher than 200 millirem per hour (mrem/hr) as contact-handled TRU waste and those with surface-dose rates higher than $200 \mathrm{mrem} / \mathrm{hr}$ as remotely handled TRU waste. 
About 98 percent (by volume) of the TRU waste produced in the DOE complex is classified as CH TRU waste.

Contact-handled TRU woste exists in a wide voriety of physicol forms, ranging from unprocessed general trash and concrete-stabilized sludge to decommissioned machine tools and glove baxes. Most of the pre-1970 (buried) waste is in 208-liter drums. Although drums are still widely used, the present trend is toward large plywood and metal boxes, which not only cost less than drums but also make more efficient use of storage volume. At present, about 70 percent of all CH TRU waste is put into boxes, most of it in special plywood boxes, obout $1.2 \mathrm{~m} \times 1.2 \mathrm{~m} \times 2.1 \mathrm{~m}$ in outside dimensions, that ore covered with o $3-\mathrm{mm}$ loyer of fiberglass-reinforced polyester and lined with polyvinyl chloride and fiberboard. These boxes are approved by the U.S. Department of Tronsportation (DOT-7A contuiners).

\section{REMOTELY-HANOLED TRU WASTE}

A small froction (about 2 percent by volume) of the TRU waste generated by the DOE complex exceeds the 200-mrem/hr limit on the surface-dose rate of $\mathrm{CH}$ TRU waste. The surface-dose rates of ulmost all packoged RH TRU waste ronge from a few hundred millirem per hour up to perhaps $100 \mathrm{rem} / \mathrm{hr}$. This waste will be hondled by shielded equipment designed especially for the purpose.

The criterio for RH TRU woste containers ore generally the some as those for $\mathrm{CH}$ TRU waste: containers are designed to Type A specifications and are desigr.ed to be retrievable for at least 10 yeors. The only differences are the dimensional characteristics of the containers themselves. The shipping casks in which the containers will be transported restrict the size of the container, as does the remote-handling equipment being designed for the reference repository.

The package criterio are presented in Table $\mathrm{C}-\mathrm{I}$ for both $\mathrm{CH}$ and $\mathrm{RH}$ TRU woste. 


\section{HASTE FORM}

\section{Combustiblity}

Gas generation

Immobli 1 zation

\section{Explosi ves}

Pyrophor ics

Hazardous materlals

Design 1 ife

structure
No $11 \mathrm{mit}$, must be packaged in steel containers or overpack

Gas-generating mazerials in any single storage room may not exceed 108 by weight

powders, ashes, etc.., must be bound in glass, concrete, ceramic, or other approved matri $x$; double contatnment allowed for special cases; gludges must contain no free liquid

\section{Not allowed}

Small quantities of radionuclide-metal pyrophorics may be accepted with other waste forms Allowed only with special procedures
and precautions

\section{CONTAINER}

10 years to allow retrievabllity

Type A requitrements
No cr ltertiony quantities are insigniflcant, and processing will probably not be avallable

No criterion for above reasons

Same as for CH TRU wogte

Same as for CH Thu waste

Same as for Cll TRU waste

Same as for CH TRU waste

Same as for CH TRU waste

Same as for CII ThU waste

TABLE C-1

INTERIM WASTF-ACCHPIANCE CRITERIA FOH CH TRU AND RRH TRUU WASTE 
Criterion

Contact-handled TRU waste

\section{PACKAGE}

\section{structure}

Handiling

weight

Dimensians

\section{Radlation}

Surface-dose rate

Surface contamination Criticality
Type A; any damaged container must be c. arpacked

Devicee to allow handling by means of a forkift

Lese than 12,000 pounds

Not larger than 8 by 12 by 9 feet

Not exceeding $200 \mathrm{mrem} / \mathrm{hr}$; sources producing more than 5000 ft $3 / y r$ must produce waste with a 3-month average of lesg than $10 \mathrm{mrem} / \mathrm{hr}$

49 CFR 173. 398

49 CFR 173, Subpart H
Remotely handled TRU waste

Axial lifting pintle

Less than 10,000 pounds

24-inch diameter, 15-foot length

Less than 100 rem/hr

49 CFR 73.398

30-galion drum, 100 grans fisstle, 55-galion drun, 200 grans Elssile; DOT-7A, 500 grams Elsslle

\section{TABLE C-1}

(CONTINUED) 


\subsection{ACCEPTANCE CRITERIA ASSUMED FOR ANALYSES REPORTED IN THE DRAFT EIS}

As discussed above, the acceptance criterio for TRU woste are still being developed by the Waste Acceptance Criteria Steering Committee. For this reoson, two different versions of potential waste-occeptonce criterio wer? used in the Droft EIS. These two versions were used in ways that yield maximum environmental-impnct predictions; while it is ossumed that the waste-acceptance cri,erio finally selected will produce smaller impacts than the impocts calculated from the the two sets of ossumed criter io. 


\subsection{TECHNICAL SUPPORT FOR GEIS - VOLUAAE 2: COMMERCIAL WASTE FARMS, PACKAGING AND PROJECTION \\ FOR PRECONCEPTUAL REPOSITORY DESIGN STUDIES ${ }^{58}$}

In support of the GEIS for rodioactive waste isolation in geologic formations DOE's Uffice of Waste Isolation provides the following information,

Prior to shipment, non-high level TRU wastes are packaged in disposable contciners. The woste containers are transported in Type 8 overpacks which may be unshielded or shielded depending on the radiation level of the surface of o disposable container.

Disposable containers are assumed to include DOT specification $17 \mathrm{C} 55$-gallon (208-liter) steel drums and DOT specification 7A steel boxes having dimensions

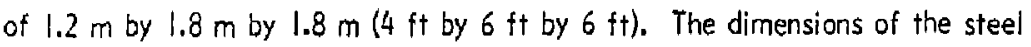
boxes have been chosen to conform to the space which is avoilable in the elevator cage postulated for the low level waste shaft at the Federal repostory. This box volume is approximately the same as that occupied by a palletized orray of 55-gollon drums (two drums by three drums) on iwo levels for a total of 12 drums per poliet.

Other disposable containers may also be used. For example, because of shielding requirements, some shipments of Ti2U-contaminated equipment and metal scrap are assumed to be packaged in the canister described for containment of fuel bundle residues. Shipment would be maue in a fuel bundle residue cask. HEPA filters which are too lorge to be occommodated in 55-gollon drums are assumed to be packaged in 80-gallon (300-liter) drums.

To satisfy the retrievability requirement, if shipments are made to interim storage rather than to a permanent disposal facility, it may be necessary to provide eitiner a liner or a disposable overpack for drums and boxes. 
All TRU waste packoged in disposoble containers will be shipped in overpacks which meet Type 8 package requirements. The mode of shipment will depend on the radiation level at the surfoce of the disposable container. Regulations permit disposable containers with surface dose rates less than $200 \mathrm{mR} / \mathrm{hr}$ to be shipped without shielding. Most 55-gallon drums in this cotegory will octually have surface cose rates less than $1 \mathrm{mR} / \mathrm{hr}$. Lead liners can be added to 55 -gallon drums to reduce surfoce dose rotes to acceptable limits if required for the protection of personnel during the handling of the drums.

For plannirig purposes, four shipment modes have been defined for TRU wastes pockaged in 55-gollon drums. These shipment modes ore described in Table C-2.

Reusable transport shields constructed to Type B package standards are available both for shipments which do not require shielding and for those which do require shielding. Shielded Type B averpocks are typically smaller than unshieided units. The container volume in reusable transport shield must be limited so that shielded weight does not cause overall package weights to exceed truck weight limits.

Drums and boxes which do not require shielding are assumed to be transported in o Super Tiger. The Super Tiger is a double-walled steel box with a fire resistant polyurethane foom filler for shock and thermal insulation. Interior dimensions ore $1.93 \mathrm{~m}$ by $1.93 \mathrm{~m}$ by $4.36 \mathrm{~m}$ (76 in by $76 \mathrm{in}$ by $17.2 \mathrm{in}$ ). The empty weight is $6,800 \mathrm{~kg}(15,000 \mathrm{lb})$, and the maximum payload is $13,600 \mathrm{~kg}(30,000 \mathrm{lb})$. Three pallets containing twelve 55-gallon drums per pallet (total of 36 crums), or three steel boxes could be transported in a Super Tiger. The overpack is loaded from one end in o horizontal position.

Shielded vans licensed for Type B shipments are not available commercially although shielded vans for LSA shipments of drummed waste are in commercial use. It is anticipated that o shielded van which meets Type B pockage standards or a Super Tiger-type overpack which incorporates some shielding could be constructed to tronsport drummed TRU waste with surface dose rotes in the I R/hr ronge. 


\section{TABLE C-2}

\section{SHIPMENT MOOES FOR 55-GALLON DRUMS}

OF NON-HIGH LEVEL TRU WASTE ${ }^{58}$

\section{Drum Surface \\ Dose Rate}

$<200 \mathrm{mR} / \mathrm{hr}$

$200 \mathrm{mR} / \mathrm{hr}-\mid \mathrm{R} / \mathrm{hr}$

$1 R / h r-10 R / h r$

$>10 \mathrm{R} / \mathrm{hr}$
Shipment Mode ${ }^{(a)}$

Unshielded scle-use van

Shielded sole-use van

Cosk with equivalent shieid thickness of 2 in. $(5.1 \mathrm{~cm})$ leod $+3 / 4$ in. $(1.9 \mathrm{~cm})$ steel

Cosk with equivalent shield thickness of $4 \mathrm{in} .(10.2 \mathrm{~cm})$ lead +1 in. $(2.5 \mathrm{~cm})$ steel

${ }^{a}$ All overpocks meet Type B pockcge requirements 
For planning purposes it is assurned that o Type $B$ transport shield incorporating approximotely $2 \mathrm{I} / 2 \mathrm{in.}(6.3 \mathrm{~cm})$ of lead equivalent shielding woulo transport 14 drums and that a shield incorporc ing approximately $4 / 12 \mathrm{in}$. $(11.4 \mathrm{~cm})$ of lead equivalent sinielding would transport six drums of TRU woste. Table C-3 and C-4 provide additional information relating waste type and appropriate container type. 
TABLE C-3

WASTE CONTAINERS FOR VARIOUS TRU WASTE SOURCES ${ }^{\text {5B }}$

\section{WASTE TYPE}

Clodding Woste

Low Level Wioste-FRP'

Noncombustible Trash

Noncombustible Trosh from $\mathrm{PuO}_{2}$ facility

Cemented Incinerator Ash

Foiled Equipment - General

Failed Equipment - $\mathrm{PuO}_{2}$ Conversion

Low Leyel Waste-MOX ${ }^{2}$

Noncombustible Trosh

Cemented Wet Woste

Filter Media

Cemented incinerotor Ash

Foiled Equipment

Intermediate Level Woste-FRP!

Noncombustible Trash

Noncombustible Trosh - $\mathrm{PuO}_{2}$ Conversion

Foiled Equipment

Foiled Equipment

Noncumbustible Trash

Foiled Equipment

Foiled Equipment

Cemented Incinerator Ash

Cemented Wet Woste

HEPA Filter Medio

\section{CONTAIINER TYPE *}

$30 "$ conisters

55 gallon drums

55 ạllon drums

55 gallon drums

4'X6'Xá' boxes

$4^{\prime} \times 6^{\prime} \times 6^{\prime}$ boxes

55 gallon drums $55 \mathrm{gr}$ :"on drums 55 guirion drums 55 gallon drums $4^{\prime} \times 6^{\prime} \times 6^{\prime}$ boxes

55 gallon drums 55 gallon drums 55 gollon drums $30 "$ conisters 55 gallon drums 55 gallon drums 30 " canisters 55 gallon drums 55 gallon drums 55 gallon drums

1 Wostes from "Fuel Reprocessing Plant".

2 Wostes from "ivixed Oxide Fuel Fabrication Plant".

* See Table C-4 
TABLE C-4

WASTE CONTAINER CHARACTERISTICS 58

\begin{tabular}{|c|c|c|c|c|}
\hline Container & Dime isions & Construction & Application & Closure \\
\hline \multirow[t]{4}{*}{ Canisters } & $\begin{array}{l}12^{\prime \prime} \text { dia. } \times 10^{\circ} \text { long } \\
(30.5 \mathrm{~cm} \text { dia. } \times 3 \mathrm{~m})\end{array}$ & $\begin{array}{l}\text { Sch. } 40 \text { SS pipe } \\
0.4 i "(1 \mathrm{~cm}) \text { wall thickness }\end{array}$ & $H L W$ & welded head \\
\hline & $\begin{array}{l}30^{44} \text { dia. } \times 10^{\prime} \text { long } \\
(76.2 \mathrm{~cm} \text { dia. } \times 3 \mathrm{~m})\end{array}$ & $\begin{array}{l}\text { Sen. } 20 \text { SS pipe } \\
0.5 "(1.2 \mathrm{~cm}) \text { wall thickness }\end{array}$ & $\begin{array}{l}\mathrm{FRW}^{(a)} \text { and } \\
\text { failed equipment }\end{array}$ & weilsed head \\
\hline & $\begin{array}{l}6.51 \mathrm{sq} . \times 16^{\prime} \text { long } \\
(16.5 \mathrm{~cm} \text { sq. } \times 4.9 \mathrm{~m})\end{array}$ & $\begin{array}{l}\text { SS or carbon steel } \\
\text { plate } 0.25 "(0.6 \mathrm{~cm}) \text { thick }\end{array}$ & BWR elements & welcled head \\
\hline & $\begin{array}{l}9.5 " s .7 . \times 16^{\prime} \text { long } \\
(24.1 \mathrm{~cm} \text { sq. } \times 49 . \mathrm{m})\end{array}$ & $\begin{array}{l}\text { SS of corbon steel } \\
\text { plate } 0.25^{\prime \prime}(0.6 \mathrm{~cm}) \text { thick }\end{array}$ & PWR elements & welded head \\
\hline Drums & $\begin{array}{l}55 \text { gallon } 22.5 " \text { dia. } \\
\times 34.8 \text { " long } \\
(57.2 \mathrm{~cm} \text { dia. } \times 88.4 \mathrm{~cm})\end{array}$ & $\begin{array}{l}\text { carbon steel } \\
\text { DOT spec. I7C }\end{array}$ & ILW and LLW & $\begin{array}{l}\text { ring clamps } \\
\text { and gosket }\end{array}$ \\
\hline Boxes & $\begin{array}{l}4^{1} \times 6^{1} \times 6^{\prime} \\
(1.2 \mathrm{~m} \times 1.8 \mathrm{~m} \times 1.8 \mathrm{~m})\end{array}$ & $\begin{array}{l}\text { carbon steel } \\
\text { DOT spec. } 7 \mathrm{~A}\end{array}$ & LLW failed equipment & $\begin{array}{l}\text { gasket or } \\
\text { welded head }\end{array}$ \\
\hline
\end{tabular}

$\overline{a_{\text {FRW }}}$ = Fuel Residue Waste (fuel hulls and hardware) 


\section{APPENDIXD}

TRU WASTE CONTAINER/GEOLOGIC MEDIA CORROSION STUDIES AND DATA BASE 


\subsection{INTRODUCTION}

Disposal of TRU wostes in deep geologic media is presently considered the most viable method for ensuring the isolation of radionuclides contained in Class $A$ waste.* Although the TRU waste canister is only one of several physical/geochemical borriers which minimize the dispersal of radionuclides fowords the biosphere, it may play a significant role during the first several hundred years af ter emplarment during which time the fission products will decay oway. The compatibility of candidate waste contuiner materials with deep geologic mediu environments is bsing investigated by DOE in a series of interrelated laboratory, bench-scale, and in situ experiments. While this work has been primarily oriented toward high-level waste and spent fuel conisters, much of it is applicable to TRU waste containers. Results presented are portially applicable to bedded and domed solt, subseabed sediment, and various types of hard rock geologic waste repository or test facilities.

Condidate canister and overpack materials (generally applicable to TRU waste containers) which satisfy appropriate requirements for barrier lifetime, costs, and mechanical properties have been identified and reviewed. Design life requirements generally range from 0.5 years for transportation and handling requirements, to 5-50 years for waste retrievability constraints, and opproximately 1,000 years for retardation of near-field, thermally driven interoctions such as waste form leaching, followed by radionuclide migration.

Important geologic medio environmental parameters which impact or potentially impact TRU waste containers include the following:

- Temperature

- Pressure

Class $A$ wastes are defined as those wastes which by their nature require isolati in deep geologic medio or similar disposal schemes. See Reference 7 for alscussion of TRU waste. 
- Media solution chemistry

- Lithostatic and hydrostatic induced stresses

- Sensitization of contained welds

- Radiolysis

- Water intrusion

Objectives of metallurgicol testing include: defining interaction kinetics and synergistic mechanisms under expected environmental conditions; providing dato necessary for woste repository design and overall repository safety analysis studies; and evaluating predictive analytical models based on such data. Corrosion data from the Project Solt Voult waste isolation test in bedded solt, dato from geothermal brine testing, and other existing data are incorporated where opplicable. The bulk of dato emphasizes corrosion studies in progress at Sandio Loboratories. Severol series of laborotory tests were conducted to evaluate the effects of expected environmental parameters on resultant corrosion rotes, The parameters represent both optimized emplacement conditions and credible, worst-case (e g., water intrusion) boundary conditions. Voriables tested include: temperature $\left(25-250^{\circ} \mathrm{C}\right)$, pressure, solution composition, oxygen concentrations, solution volume/surfoce areo ratios, welding and crevice efferts, and dry and moist solt effects. 24 
[AUL:E [ ]. |

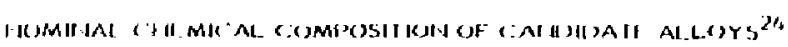

\begin{tabular}{|c|}
\hline Alloy \\
\hline IOlu mird Steal \\
\hline 4130 Corbar Steal \\
\hline Corlen A steete \\
\hline $21 / 4(1,-1) \mathrm{Mo}$ \\
\hline Mavedl thross \\
\hline $90-10$ Cupronickel \\
\hline $55-304$ \\
\hline $55-316$ \\
\hline SS-Mitronic $5 u^{9}$ \\
\hline $5 S-20-C b 3^{\mathrm{t}}$ \\
\hline SS-Ebrite 26-1 \\
\hline Manet 4000 \\
\hline Incolay $825^{a}$ \\
\hline Inconel $600^{\circ}$ \\
\hline Irucanei $625^{\circ}$ \\
\hline I lustellor $C-276^{C}$ \\
\hline Zirtulor 2 \\
\hline litunium, C.P. \\
\hline ricode $12^{t}$ \\
\hline MI.3514 \\
\hline
\end{tabular}

$$
\therefore-\quad \text { Min. }
$$$$
\text { si }
$$$$
\operatorname{lin} \quad-1 \cdot 1
$$$$
\text { M }
$$$$
0.18 \text { o. } 0
$$$$
\text { a.25 }
$$$$
\text { U. } 3
$$$$
-
$$$$
\text { -. }
$$$$
\text { 1.. } 20.8
$$$$
\text { (3. } 5
$$$$
1.0
$$$$
\text { -- -. }
$$$$
\text { (o. })
$$$$
2.2
$$$$
\text { -- -- }
$$$$
\cdots
$$$$
\text { 0.0EM 2.0M }
$$$$
\text { 1).06m } 5
$$

$0.0 \mathrm{~m} 2.0 \mathrm{~m}$

$$
\begin{aligned}
& -.0 \mathrm{M} \\
& \mathrm{I} . \mathrm{OM}
\end{aligned}
$$$$
-
$$

$0.4 \mathrm{M}$

$-2$

0.2

1.0

0.030 .5

$0.04 \quad 0.20$

o.us

0.2

$0.4 \mathrm{M}$

0.2
0.2

0.2
0.20

$0.20 \quad 15.5$

$$
\text { U. } 2
$$

0.12

$--$

$\begin{array}{lll}-- & - & - \\ 0.012 & -- & --\end{array}$

-- -. -.

Mo.
-
0.2
$\cdots$
1
$\cdots$
$\cdots$
--
2.5
2.25
2.5
1
--
3.0
--
9.0
.7
--
.-
0.34
10

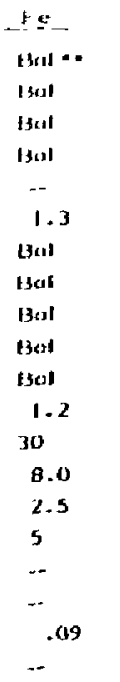

$-\because 1$
.-
--
.-
--
60
ab.
--
--
--
3.5
$10.2 M$
31.5
2.2
.-
--
--
-
--
--
--

Qtikers

--

$.021 \mathrm{i}$

$--$

$39<1$, isn

--

$0.2 \mathrm{Nb}, .2 \mathrm{~V}$

--

$-$

$0.9 \mathrm{Ti}$

Nb; 0.211

aw

1.5Sin, 9H.221

$99.51 \mathrm{i}$

$98.91 \mathrm{i}$

$35 \mathrm{Co}$

- in verutes muximurn

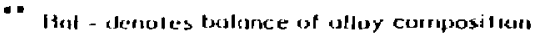

roschernutks:

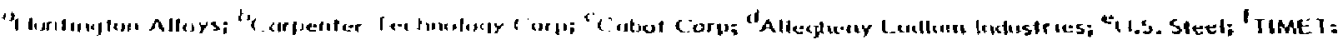

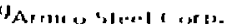


TABLE D-2

CORROSION RATES OF CANDIDATE ALLOYS IN DEOXYGENATED SOLUTIONS $\left(250^{\circ} \mathrm{C}, \mathrm{P}=5 \mathrm{MPa}\right)^{24}$

\begin{tabular}{|c|c|c|c|}
\hline Alloy & $\begin{array}{l}\text { Brine A } \\
(\mathrm{mm} / \mathrm{yr}) \\
\end{array}$ & $\begin{array}{l}\text { Brine B } \\
\text { (mm/yr) }\end{array}$ & $\begin{array}{l}\text { Seowoter } \\
(\mathrm{mm} / \mathrm{yr}) \\
\end{array}$ \\
\hline 1018 Mild Steel & 1.7 & 0.07 & 0.4 \\
\hline Corten A Steel & 0.9 & 0.05 & 0.2 \\
\hline $21 / 4 \mathrm{Cr}-1$ No Steel & $1.0 * *$ & $0.1 * *$ & 0.2 \\
\hline Lead & 0.5 & 0.3 & 0.3 \\
\hline Copper & 0.07 & 0.05 & 0.05 \\
\hline Naval Bross & 1.0 & - & 1.0 \\
\hline 90-10 Cupronickel & 0.14 & - & 0.07 \\
\hline SS-304L & 0.018 & 0.01 & 0.006 \\
\hline$\$ 5-316 \mathrm{~L}$ & 0.015 & -- & 0.005 \\
\hline S5-Nitronic 50 & 0.008 & -- & 0.003 \\
\hline SS-20Cb3 & 0.007 & -- & 0.005 \\
\hline SS-Ebrite 26-I & 0.016 & $\cdots$ & 0.005 \\
\hline Monel 400 & 0.03 & -- & 0.1 \\
\hline Incoloy 825 & 0.006 & - & 0.004 \\
\hline Inconel ó00 & 0.009 & 0.007 & 0.005 \\
\hline Inconel 625 & 0.005 & 0.001 & $0.012^{*}$ \\
\hline Hastelloy C-276 & 0.007 & - & 0.0015 \\
\hline Zircaloy-2 & 0.001 & - & -- \\
\hline Titonium C.P. & 0.003 & - & 0.006 \\
\hline Ticode 12 & 0.0006 & - & 0.005 \\
\hline
\end{tabular}


TABLE D-3

REPRESENTATIVE SOLUTION COMPOSITIONS ${ }^{24}$

(mojor ions)

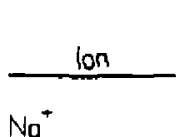

No

$k^{*}$

$\mathrm{Mg}^{+2}$

$\mathrm{Co}^{-2}$

$\mathrm{Sr}_{\mathrm{r}}+2$

$\mathrm{Cl}^{-}$

$\mathrm{So}_{4}^{-2}$

1

$\mathrm{HCO}_{3}{ }^{-}$

$\mathrm{Br}^{-}$

$\mathrm{BO}_{3}$

pH

Total Dissolved

Solids:

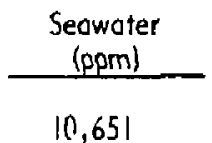

380

1,272

400

13

18,980

884

0.05

146

65

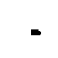

8.1

$35 g / 1$

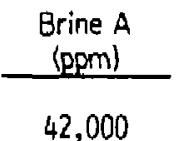

30,000

35,000

600

5

190,000

3,500

10

700

400

1200

6.5

6.5

175,000

3,500

10

10

400

10

\section{5}

10

900

15

5




\section{CURRENT DOE CANISTER CORROSION PROGRAMS AND RESULTS}

Several DOE funded corrosion studies related to $\mathrm{HLW}$ isolation canisters are now in progress and are appropriate for expected TRU waste containers. Such studies include corrosion related to woste solidificotion processes (internal canister corrosion), and (impatibility of the condidate alloy with both the waste and expected geologic medio environments. $16-20$

A long-term (50,000-hour) compatibility study of condidate HLW gloss-metalrack salt interactions is being conducted at the Sovannah River Laboratory. 18,27 This study includes internal canister corrosion measurements (from in-can melting of glass) as well as long-term, dry salt interaction evoluations. Very few results from the long-term interactions segment are presently available. This information will be useful especially for the container/solt interaction.

The compotibility of seven metals and eigint alloys (Ta, $\mathrm{Hf}, \mathrm{Au}, \mathrm{Ag}, \mathrm{Pb}, \mathrm{Ti}, \mathrm{Cu}$, 1018 mild sieel, 316 stainless steel, Everdur bronze, Monel, Coronze, Hastelloy $\mathrm{C}$, Zircaloy-2, and alpho-bross) with $250^{\circ} \mathrm{C}$ concentroted brine is being studied at Pennsylvanio State University to determine relative corrosion resistances. ${ }^{19}$ The only result to date is that no catastrophic breakdown has been observed with ony of the metals tested.

The Swedish Nuclear Fuel Safety Project task group has recommended the following canisters for disposal of spent fuel placed in hard rock formotions: 20

- Reprocessed waste will be packaged in a ómm-thick titonium conister with o $100 \mathrm{mrn}$-thick lead lining.

- Spent unreprocessed fuel will be encapsulated with a 200mm-thick copper conister.

- Spent fuel assemblies might also be enclosed in ceramic alumino conisters produced by sintering under hot isostotic pressure. 


\subsection{SANDIA LABORATORY RESULTS}

The corrosion program at Sandia consists of both laborotory and field testing phases. The $70^{\circ} \mathrm{C}$ data presented below on crushed salt and weld effects are also opplicable to the case of TRU container disposal in bedded sait, and to long-term corrosion of the alloys after the thermal output of other types of waste (spent fuel and high-(evel) hos diminished.

A wide range of metals representing many different alloy groups has been considered as condidate commerciol HLW containment materials for this progrom and it is appropriate that they be included in the TRU contoiner dato bose. The alloy selection was based on published corrosion results in chloride medio at both low and elevoted temperatures. Some of the alloys, particularly copper, lead, and cupronickel, must be considered only as potential container overpack materials becouse of their very low mechanical strength. A list of candidate metals and their chemical compositions is given in Table D-I.

The principal objective of the Sandia Laboratory studies hos been to provide preliminary scoping dota and to select six to eight metals for comprehensive study from the Table D-I list of over 20 candidate metals.

\section{I.1 EFFECT OF SOLUTION COMPOSITION}

The effect of two near-saturated brines, olong with seawoter plus seo sediments, on the corrosion rates of many alloys in $250^{\circ} \mathrm{C}$ deoxygenoted solutions, is shown in Table D-2. The composition of the two brines and seawoter is given in Table $\mathrm{D}-3$. Brine $\mathrm{A}$ is a high $\mathrm{Mg} / \mathrm{K} / \mathrm{Na}$ chloride brine and is representotive of water which might intrude into the proposed Waste Isolation Pilat Plant (WIPP) site by percolation through on overlying potosh zone; it is also considered tentatively representative of minute brine inclusions fourid in bedded-solt formations. Brine $B$ is o near-soturated, predominantly $\mathrm{NoCl}$ brine representative of dissolved, bedded solt of the $800 \mathrm{~m}$ horizon of the proposed WIPP site. ${ }^{24}$ 
The interesting observotion from these data is that the solution corrosiveness increases in the order: brine $B<5$ eowater < brine $A$. This result is due to the differences in $\mathrm{pH}$ of the hot solutions, as shown in Table 0 -4. These reported $\mathrm{pH}$ volues were meosured of $25^{\circ} \mathrm{C}$ after heating the solutions to the indicated temperature and quenching, and although they are not to be taken as the actual volues at temperature, they are indicative of an irreversible acid producing reaction which occurs in brine $A$ and seawoter. This reaction is the hydrolysis of $\mathrm{MgCl}_{2}:$

$$
\mathrm{MgCl}_{2}+2 \mathrm{H}_{2} \mathrm{O} \rightarrow \mathrm{Mg}(\mathrm{OH})_{2}+2 \mathrm{HCl}
$$

The actual $\mathrm{pH}$ will be somewhat higher thon the volues in the table due to bisulfate and bicarbonate equilibria. Localized attock on mirror polished coupon jurfoces was minimal for most of the condidate alloys studied in the three solutions.

\subsubsection{EFFECT OF OXYGEN}

The effect of a substantial quantity of dissolved oxygen on the corrosion rates of selected alloys in brine A and seawater is shown in Table D-4. A constant partiol pressure of 1 MPa oxygen was used during the course of the experiment to maintain a high level of dissolved oxygen; this should represent an overtest of the worst-case effects of oxidizing radiolysis products on corrosion. The effect of oxygen was greater in the case of seawater than brine A because of greater oxygen solubility in seowater thon brine A. It is interesting to note that the oxygenated corrosion rates of alloys studied increosed over their corresponding deoxygenated rates in Toble D-2. Many of these metals have been shown not to support on oxygen current at $25^{\circ} \mathrm{C}^{16}$; this apparently is not the case at $250^{\circ} \mathrm{C}$. This effect and the unexpected discovery that Hastelloy C-276 pitted in these solutions will be investigated further by Sandia. 24 
TABLE D-4

CORROSION RATES OF CANDIDATE ALLOYS

IN OXYGENATED SOLUTIONS ${ }^{24}$

(250 ${ }^{\circ} \mathrm{C}$ and $\mathrm{P}=7 \mathrm{MPa}$ )

$\left(\mathrm{O}_{2}\right)=600 \mathrm{ppm}$ in Brine $\mathrm{A}$ and $1750 \mathrm{ppm}$ in Seawoter)

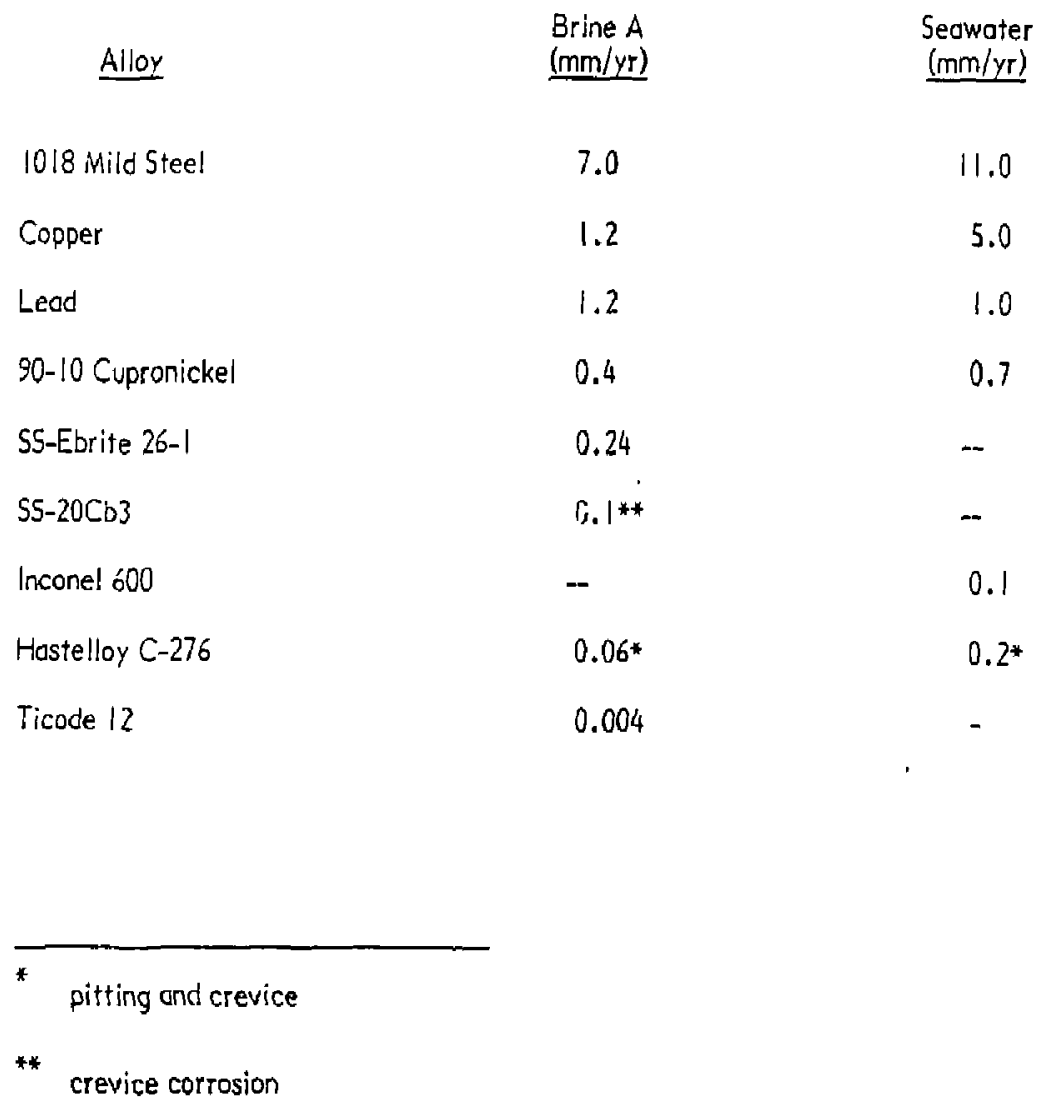




\subsubsection{EFFECT OF TEMPERATURE}

The effect of temperature (see Table D-5) on the initiol corrosion rate of 1018 mild steel in deoxygenated seawater and brine $B$ was determined over a temperature range of 25 to $200^{\circ} \mathrm{C}$. These calculated rates were on order of mognitude higher than meosured, similar, long-term, weight loss results shown in Table D-2. This difference resulted because the electrochemicol derived value represents an instantaneous initial rote. However, useful quantities are the apporent activation energies which were calculoted using these initiol results. These volues equaled $5 \mathrm{kcal} /$ mole for brine $B$ and $4 \mathrm{kcal} / \mathrm{mole}$ for seowater. A more extensive study of temperature effects on the corrosion of selected candidate metals is presently in progress. 24

\subsubsection{EFFECT OF MOISTURE CONTENT (ORY, MOIST)}

An experiment was conducted in which coupons were placed in crushed solt at $200^{\circ} \mathrm{C}$ with 100 percent relative humidity present. The following corrosion rates $(\mathrm{mm} / \mathrm{yr})$ were measured at the conclusion of this test: 1018 mild steel $=0.15$; SS-304 $=0.004 ; 55-20 \mathrm{Cb} 3=0.004$; Inconel $600=0.004$; and Ticode $12=0.004$. As expected, all of these rates were less than those under inundated brine $B$ conditions shown in Table D-2. The corrosion rates of 1018 mild steel and 55$304 \mathrm{~L}$ in dry crushed bedded salt with $1 / 2$ percent water added were not measurable of $25^{\circ} \mathrm{C}, 70^{\circ} \mathrm{C}$, or $200^{\circ} \mathrm{C}$ after five months of exposure. At $70^{\circ} \mathrm{C}$ and $200^{\circ} \mathrm{C}$ the steel samples showed only slight surface corrosion. The SS-304L samples were marked with a few small pits. These experiments confirm well known observations that relatively dry solt mines are not corrosive to even susceptible alloys like 1018 mild steel.

\subsubsection{EFFECT OF WELDING AND CREVICES}

Welded coupons with clomped crevices made from 1018 mild steel, SS-304L, and Hastelloy $\mathrm{C}-276$ were exposed to deaeroted brine $\mathrm{B}$ of $70^{\circ} \mathrm{C}$, and $200^{\circ} \mathrm{C}$. Crevice corrosion problems were nonexistent in these deoerated solutions. The 1018 


\section{TABLE D-5}

EFFECT OF TEMPERATURE ON QUENCHED SOLUTION PH

\begin{tabular}{|c|c|c|c|}
\hline $\begin{array}{l}\text { Temperature } \\
\text { (c) }\end{array}$ & $\begin{array}{l}\text { Seawater } \\
25^{\circ} \mathrm{C} \mathrm{pH} \\
\end{array}$ & $\begin{array}{r}\text { Brine A } \\
25^{\circ} \mathrm{C} \mathrm{PH} \\
\end{array}$ & $\begin{array}{r}\text { Brine } \mathrm{B} \\
25^{\circ} \mathrm{C} \mathrm{pH} \\
\end{array}$ \\
\hline 25 & 8.1 & 6.5 & 7.2 \\
\hline 100 & 8.6 & 7.0 & 7.6 \\
\hline 200 & 5.5 & - & 6.6 \\
\hline 250 & 3.9 & 3.4 & - \\
\hline 270 & 3.3 & - & 6.3 \\
\hline
\end{tabular}


steel samples exhibited general corrosion but no weld attack. The SS-30itL specimens showed numerous pits around the welded areas at $70^{\circ} \mathrm{C}$ only, whereas the Hastelloy C-276 samples were virtually immune from ottack. Corrosion rates were again unmeasurable at $70^{\circ} \mathrm{C}$. Measured corrosion rates at $200^{\circ} \mathrm{C}$ are os follows: $1018=0.1 \mathrm{~mm} / \mathrm{yr} ; 55-304 \mathrm{~L}=0.005 \mathrm{~mm} /$ year; and Hostelloy C-276 = $0.0001 \mathrm{~mm} / \mathrm{yr}$. The lack of pitting of $\$ S-304 \mathrm{~L}$ at $200^{\circ} \mathrm{C}$ was postulated to be due to a significant separation between the rest and pitting potentials in deoxygenated high temperature brine. 24

\subsubsection{EFFECT OF SOLUTION VOLUME AND HYDROSTATIC PRESSURE}

Most of the Sandio coupon experiments were conducted with a solution valume/ alloy surface area ratio $c^{+} 2-3 \mathrm{ml} / \mathrm{cm}^{2}$ and a pressure of $5 \mathrm{MPa}$. Lowering the solution volume/surface area ratio by a factor of 10 doubled the corrosion rate of 1018 mild steel. This result was postulated to be due to the lower observed $\mathrm{pH}$ of the small volume experiments (3.2 versus 4). While this effect on the more corrosion resistant alloys is unknown, it was not expected to be os great. 24 The effect of increasing the hydrostatic pressure on a wide ronge of alloys under deoxygenated conditions was to increase slightly the corrosion rate but within experimental error and has resulted in further investigation. 


\section{APPENDIXE}

MILD STEEL TRU WASTE CONTAINER CORROSION

DUE TO INTERACTION WITH DISPOSAL ENVIRONMENT AND TRU WASTE FORM 


\subsection{INTRODUCTION}

The TRU contominated wastes from nuclear facilities ore often pockoged in 208liter carbon steel drums or large (1.4-5.7 cubic meter) carbon steel boxes. While no credit is generally given to the container for containing the activity in a shallow land burial site, the integrity of the contoiner material in retoining radioactivity is being ccnsiderct for specially designed waste containers and is being evaluated for the present TRU and high-ievel waste (including spent fuel) management programs. The TRU waste container failure can result from either mechanical failure or corrosion attack due to interactions with the disposal environment or the TRU woste form. The following is part of the TRU waste container data base. 


\subsection{TRU WASTE CONTAINER CORROSION IN SOIL $\mathrm{S}^{21}$}

Soil as a corrosive environment is probably of greater complexity than any other environment. Therefore, it is difficult to make absolute predictions of the rote of corrosion of metals in soils. Only some generalizations regarding soil types and corrosion can be made. The following sections discuss the charocteristic features of the soil as a corrosive environment, however, it must be remembered that the absolute carrosion rate will depend on the interaction of the climate, rainfall and the various soil reactions.

It has been found that the measured corrasion rate in soils is dependent on whether moteriol wos buried in undisturbed soil, such as immersion of pilings, or in disturbed soils, such as trenches or excovations which are dug and refilled. In general, the corrosion in undisturbed soil is lower than in disturbed soils. This difference is mainly attributed to the aeration of the soil. The disturbed soils hove a higher oxygen content which generally leads to higher corrosion rates. The results presented herein hove been obtained from disturbed soils and thus closely simulate the conditions in radioactive waste burial sites.

Corrosion rate is generally expressed as the overage uniform corrosion rate in $\mathrm{mg} / \mathrm{dm}^{2} /$ day (mdd), which expresses the loss of weight of the material, or mils per year (mpy), which given overage rate of penetration of the metal by the corrosion process. (Conversion of mdd to mpy: $m p y=m d d x \quad 1.44 /$ density $\left(\mathrm{g} / \mathrm{cm}^{3}\right)$ of the riaterial.) In the cose of pitting, the maximum penetration of the metal by pitting in mils for the total exposure period is given.

A review of the work that follows implicitly supports the concept that corrosion of metals in soil environments is electrochemical in noture, therefore the principles of electrochemical corrosion $n$ be used to study corrosion attock in soil and estimate the rate of metal deyradation. In the case of ferrous alloys, minor compasition and structure changes in the steels ore not importont for corrosion resistance. Similorly, cold working and different heat treotments do not have a significant effect on the rate of corrosion in soils. However, as the 
steel is made more resistant to uniform corrosion, i.e., possivoted, it becomes more susceptible to pitting corrosion.

The corrosion behavior of steels in soils is generally dependent on the soil type. Both the physical and chemical characteristics of the soil affect the type and rate of corrosion. It must be remembered, however, that the absolute corrosion rate will depend on the effect of the climate foctors, such as the amount of roinfall, temperature, air movement and sunlight on the soil.

The criteria could ue used to predict the corrosion behovior of mild steel drums used for containment of solidified TRU wostes.

\subsection{MATERIAL CONSIDERATIONS}

In a mojor investigotion, by the Notional Bureau of Standards, 31 to determine the corrosion of metals in soils, a large number of samples of wrought steels, low alloy steels and high alloy steels were exposed for over 12 years in vorious $t / p$ pes of soils in the United States. It was concluded that the differences in the soils was so great that the overage rate of corrosion of a given steel for all soils would have little value. In the cose of various wrought steels exposed to the same soil the corrosion rate was similor with respect to the weight loss and the pit depth distribution. However, the some steel exposed to different soils was attocked differently. Therefore, the soil type was judged as a better criterion to determine the corrosion rate of steels. Generally, the rate of uniform corrosion of alloyed steels is less than ordinary steels, but the olloy steels are more susceptible to pitting corrosion. 21

\subsection{CHARACTERIZATION OF SOILS ${ }^{21}$}

Soils are commonly classified according to the general size range of their inorganic perticulcte motter; sand $(0.07$ to $2 \mathrm{~mm})$, silt $(0.005$ to $0.07 \mathrm{~mm})$, and clay $(0.005 \mathrm{~mm})$. The proportionate coittent from these three groups determines the soil type. Figure E-I represents the commonly used terminology for the various . sportions of sand, silt and clay. 32 


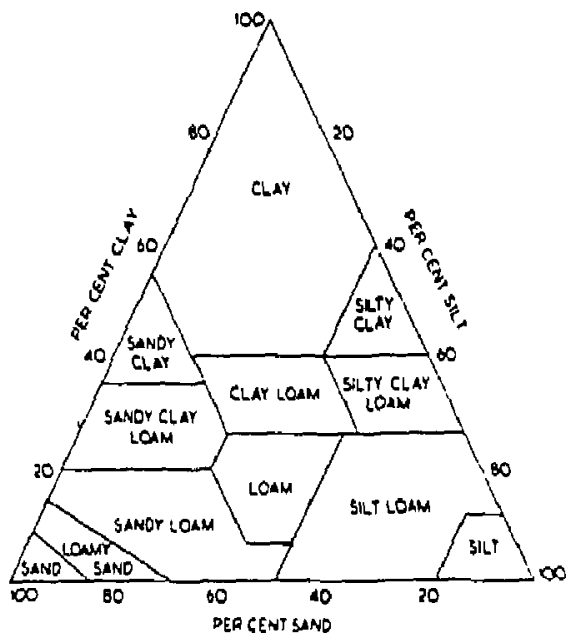

FIGURE E-1

PRIOPORTIONS OF SAND, SILT AND CLAY MAKING UP THE VARIOUS GROUPS OF SOILS CLASSIFIED ON THE BASIS OF PARTICLE SIZE 
Since soils contain organic matter, moisture, gases, and living organisms as well as mineral porticles, it is apparent that the relative size range does not determine the whole nature of the soil structure. In fact, most soils contain an aggregate of particles within a matrix of organic and inorganic colloidal matter. This aggregate determines the physical and chemical properties of soil such os the moisture content, aeration, biological activity and alkali accumulation. The soil characteristics at a given site may also vary as a function of the depth below the surface. Corrosion surveys bosed on surface observotion give little informofion as to the actual environment of the buried material, since the various strato of the soil above the buried material are also important. The strota determine the accessibility of the air and moisture to the soil surrounding the buried material.

The clay content of a soil is the most important inorganic constituent of the soil. The sand and the silt in the soil generally remain inert; but the wedthering of the clay can cause vorious changes in the physical and chemical properties of the soil. These changes can hove significant effect on the corrosion of buried metals.

\subsubsection{PHYSICAL PROPERTIES}

The physical properties of soils that affect corrosion are chiefly those that determine the permeability of the soil to air and water. The particle size distribution is the most important factor, influencing both the aerotion and the moisture content of the soil. In generd, sondy soils hove a free circulation of air and a low water-holding capacity. Therefore, the corrosian rate in these soils is low and opprooches the otmospheric type. Cloy and silty soils are choracterized by a fine texture, high water holding capacity, poor aeration and poor drainage. These soils give higher corrosion rotes and represent conventional aqueous corrosion. Cloy particles are highly plastic and become sticky and impervious when saturated with water. Such soils shrink and crack on drying and swell on rewetting. This process of shrinkoce and crocking on drying, and swelling on rewetting, gives o greater rate of corrosion. 


\subsubsection{AERATION}

Aeration, or the ovailability of oxygen of the burial site, plays a direct role on the type and rate of corrosion of the metal. The effect of oxygen is, however, depeident on other properties of the soil, such as the ocidity and the moisture contert. Generally, poor aeration and high volues of acidity and salt content increase the corrosion rate. Well aerated alkaline soils are typicaily not corrosive. ${ }^{21}$

In well aerated soils a protective oxide film may form on the metal, which would prevent further degradation of the metal. However, the protective film may be punctured due to local chemical changes in the soil and lead to pitting of the metal. The rate of pit growth is also dependent on the aeration of the soil. In well oeroted soil the rate of pitting, al though initiolly high, falls off ropidly with time. On the other hand, in poorly aeroted soils, the rate of pitting decreases slowly, if at all, with time. In addition, it appears probable thot aeration of soils may affect corrosion not only by the direct action of oxygen in forming protective films, but olso indirectly through the influence of oxygen reacting with and decreasing the concentration of the organic complexing agents or depolarizers naturally present in some soils which greatly stimulate local-action cells. In th . regard, the beneficial effect of aeration extends to sails that harbor sulfate-reducing bacterio, because these bocteria become dormant in the presence of dissolved oxygen.

Local differences in the packing of the soil and its moisture content may develop oxygen concentration cells. The oreo of the metal which is not accessible to oxygen is anodic, i.e., it corrodes, to the oreas which ore readily accessible to oxygen. The rate of corrosion is dependent on the relative size of the anode and the cothode. A small size ratio gives rise to ropid pitting. The presence of oxygen concentrotion cells has been cited as one of the major reasons for local corrosion of pipelines. ${ }^{21}$ 


\section{2. .2 MOISTURE CONTENT}

The principle function of the soil moisture is to furnish the electrolyte for carrying the current and promate the electrochemical corrosion process. The moisture content controls the amount of dissolved salts, which determines the soil resistivity of the electrolyte, os well as the acidity or alkalinity and the development of the chemical reactions between the primary products of metallic corrosion and the electrolyte.

The resistivity of soil is extensively used as the main single parameter to predict the corrosiveness of a soil. ${ }^{31}$ Combined with resistivity, absolute moisture content volues have also been used to determine the aggressiveness in soils. Water content is regarded as one of the most important factors controlling the rate of corrosion of metols in soils.

The moisture content and the oxygen content of the soil are interrelated and behave synergistically. A porous soil may retain moisture over a long period of time or may allow optimum aeration and both these factors tend to increase the initial rate of corrosion. The wet-dry alteration, either temporal or spatial, leads to higher corrosion rates than would be obtained with a constant environment. This same fluctuation also leads to greater variation in biological activity in soils.

\subsubsection{CHEMICAL PROPERTIES 21}

A lorge number of chemical elements exist in soils, but most ore combined in insoluble compounds which exert little direct chemical influence on corrosion. These inert compounds of soils are chiefly oxides of silicon, oluminum and iron. Chernical onalyses of soils, for corrosion studjes, are usually limited to determinations of constituents that are soluble in water.

The development of acidity in soils is a result of the natural process of weathering under humid conditions. The acidity is expressed os the $\mathrm{pH}$ value. Most soils hove a pH of from 4.5 to 10 . It should be emphasized that the $\mathrm{pH}$ value is a measure of the existing hydrogen ion concentration and not the tatal 
quantity of ionizoble hydrogen in the soil, which is teferred to as the lotol soit acidity. Becouse the pH and total acidity depend on the type of clay, amount of organic matter, exchongeable bases, and salts, the relationship between pH and total acidity is not constant for all soils at all times. Generally, soils rich in organic matter are wel! buffered and retain greater omounts of ocidity or alkalinity than sandy soils. Such buffered soils resist changes in soil pHt and prevent development of low pHit and very corrosive conditions. The chemical properties of soils may also vory with time, due to bacterial action.

\subsubsection{INORGANIC MATTER}

The main inorganic ions in soils are positively charged cotions, such os $\mathrm{Co}^{++}$, $\mathrm{Mg}^{++}, \mathrm{No}^{+}$and $\mathrm{K}^{+}$, and negatively charged anions such as $\mathrm{Cl}^{-}, \mathrm{SO}_{4}^{--}, \mathrm{CO}_{3}^{--}$, and $\mathrm{HCO}_{3}^{-}$. As a result of disintegration of rocks and micro-organic reaction, some metasilic acid $\left(\mathrm{H}_{2} \mathrm{SiO}_{3}\right)_{n}$ may be present. Depending on the suriounding geological structure, traces of iron, copper, lead and zinc may also be found in the soil.

The effect of soluble solts on corrosion is shown in Table E-I. It is observed that, in general, the corrosive soils have large solubie salt contents. However, the absolute concentration of the various constituents connot be used to determine the corrosiveness of the soil becouse of the inconsistencies shown in the rate of corrosion at locations where the chemicol composition is not markedly different. ${ }^{31}$ It should be remembered that only the salts that are soluble in the oil at a given time play a, ole in the corrosion process and the amount of dissolved salts is controlled by the moisture content of the soil. Since the soluble ions contribute to the conductivity of the soil, the relation between the conductivity and the corrosion rate of the soil does give an indirect indication of the effect of inorganic matter on the corrosiveness of soils.

\subsubsection{ORGANIC MATTER}

There are two types of organic motter found in soil: (i) non-living matter derived from decay of vegetable matter from drainage and in waters from marshy land, and (ii) living, microscopic organisms such os bacterio and algoe. The non-living 


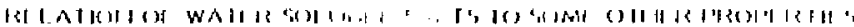

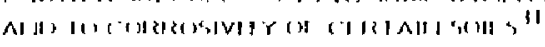

Ax IIITY

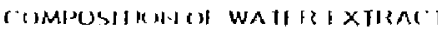
(inge-en per lith y of soil)

SOIL TYPE

Unidentified silt toam

Keyport logm

Rustom sandy Joum

Merrimoc grovelly sondy loam

Miomi silt loom

Everelt gravelly sondy ion

Nor folk fine sand

Mork $\mathrm{Co} \quad \mathrm{Mg} \quad \mathrm{CO}_{3} \mathrm{HCO}_{3} \mathrm{rI} \quad \mathrm{SOr}_{4}$

LEAST CORTOSIVH

\begin{tabular}{|c|c|c|}
\hline 0.67 & 0.72 & 0.39 \\
\hline & $\cdots$ & $\cdots$ \\
\hline-- & $\cdots$ & --- \\
\hline$\cdots-$ & $\cdots$ & $\cdots$ \\
\hline 0.27 & 0.50 & 0.31 \\
\hline & -- & --- \\
\hline
\end{tabular}

\subsection{6}

-..-

$--$

0.48

0.70

0.03

$\cdots$

$--\cdot$

$---$

0.12

$---$

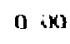$$
\text { O }
$$$$
\text { --- }
$$$$
0.00
$$$$
\text { -... }
$$

MOST CORROSIN

\section{Forgo cloy loom}

Unidentified olkoli soil

Muck

Peot

Montezuma clay adolye

Merced silt foam

$\begin{array}{lllllll}1.42 & 1.72 & 2.55 & 0.00 & 0.71 & 0.01 & 4.43 \\ 8.15 & 3.70 & 0.70 & 0.00 & 0.24 & 0.18 & 11.96 \\ 2.15 & 1.92 & 1.55 & 0.00 & 0.016 & 1.69 & 2.30 \\ 1.52 & 1.30 & 4.06 & 0.00 & -2 . & 2.27 & 2.17 \\ 1.50 & 0.06 & 0.18 & 0.00 & 0.12 & 0.99 & 0.49 \\ 8.38 & 0.38 & 0.22 & 0.02 & 1.87 & 1.12 & 5.57\end{array}$

CorkTOSIVITY

Maximumn

pill (ropth

in thessciner

II yeurs

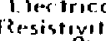

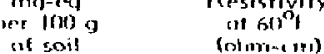

(imils)

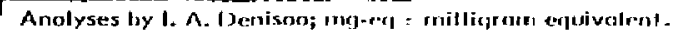

2 Alkoline. 
organic matter do not directly interact in the corrosion process; they generally just change the chemical composition of the soil. The living organism con offect the corrosion behovior in the following woys:

- Influence the anodic and cathodic reactions

- influence the protective films

- Influence the environment

Microorganisms are classified according to their ability to grow in the presence or absence of oxygen - aerobic-organisms that require oxygen in their metabolic process, and onoerobic-orgonisms that grow most fovorably in environments containing little or no oxygen.

The most important anaerobic bacterio which influence the corrosion behavior of buried steels are sulfate reducing. These reduce the sulfate to sulfide by reacting with the hydrogen in the soil. The presence of sulfide ions markedly increases the anodic reaction. The corrosion product in this reaction is iron sulfide which deposits on the steel.

Aerobic bacterio react with sulfur to produce sulfuric acid. These bacterio thrive in low $\mathrm{pH}$ environments and con sometimes produce localized sulfuric acid concentrotion of up to five percent by weight. Thus, these bocterio can produce locolly very corrosive environments.

Sulfate-reducing and sulfur-oxidizing bacteria can operate in a cyclic fashion when soil conditions change. Sulfate-reducing bacterio grow rapidly auring rainy seasons when the soil is wet and air is excluded, and sulfur-oxidizing bacterio grow ropidly during dry seosons when oir permeates the soil. In certrin areos, this cyclic effect has caused extersive corrosion damage of buried steel pipelines. Also, it is evident that the presence of micro-organisms can accentuate conditions of differential aeration in soils. 
Other organisms, such as iron bocteria, assimilate ferrous iron from the solution and precipitate it as ferrous or ferric hydroxide in sheets surrounding their cell walls. ${ }^{7}$ The growth of iron bacterio frequently iesults in tubercles on steel surfoces that tend to promote crevice attack. Certain bacteria are capoble of oxidizing ammonio to nitric acid. Diluted nitric acid corrodes iron and most other metols. In most soils, the amount of avoilable ammonio is not high enough to cause an appreciable accumulation of nitric acid; however, these bacteria moy be important where ext:nsive use of synthetic ammonio fertilizers has been employed on cultivated fields above buried materials. Finally, most bocteria also produce carbon dioxide, which can cantribute to the formation of carbonic acid and increase corrosivity. Some of the more important micraorganisms and their characteristics are listed in Table E-2.

No detailed study of the effect of organic matter on the life of steel structures has been made. The most important aspect of this form of corrosion is that it is locolized and, thus, can have a sigrificant effect on the integrity of a containment vessel.

\subsubsection{INFLUENCE OF PH}

The influence of $\mathrm{pH}$ on the corrosion behovior of iron is very characteristic, as shown in Figure E-2. In an acid solution iron dissolves freely and evenly with the evolution of hydrogen. With the increose in $\mathrm{pH}$, i.e., decrease in acidity and hydrogen ion concentration, the corrosion rote decreases regularly until a pH value of about 4.0 is reached. When the influence of owyen seduction at the cothode begins to be appreciable, in the $\mathrm{pH}$ range $4.0-9.5$, the rote of attack is almest constant and is generally controlled by the supply of oxygen. With an increose in the $\mathrm{pH}$ value, the corrosion rate decreoses more sharply to a minimum of about $\mathrm{pH} 12.0$, and on further increase in the $\mathrm{pH}$ volue, the corrosion rate starts to increase again with the formation of ferrates.

Since the $\mathrm{pH}$ of most soils is within 4.0 to 9.0 , the corrosion rate is expected to be similar. Although the overall attack may be reduced by increasing the $\mathrm{pH}$ volue, there is o real danger thot the attack will be concentrated at o localized 
1 ABH IF F-2

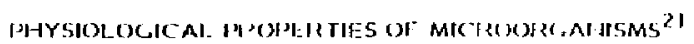

Group and Type

I. Sulfate reducing, (Desulfovibrio
sulf fur icans)

11. Sulfur oxidizing (Thiotsoniling

3il. Thiosult ate oxidizing frhiobocillus Thiosulfates,
sulfur

ulf ates, thiosul fates, sulfites, sulfur, hyp
sulfides

sulfur, sulfides,

Sulfuric ocid

Aerobic thioporus)

IV. Iron bactería (Crenothrix ond
Acrobic:

Ferrous corbonole, ferrous bic orbonote, manyou
Produrts sulf fole and sulfur
Approximedt:

recichion (pal t)

Major L.red

H. Hoshilant

1 lyatrangen sultide

Water, muds, sewrign.

oil wells, soils,

concrele

Soil composts, "vitur and rock phosphates.

solls confoining insulfur coinpouiuls

Oplimen: 2,0-4t.0

Limits: 0.5-6.0

Uptimunu: 6.-7.5

limits: 5.-9.0

Optimman: 2s-30

Maxitume 55-65

Optimum: 20-30

Widety distr ibuted, sea and river woter,

Sulfur to sulfate

inud, sewnge, soil

Optinum: Close

to neutro

Limits: $7.0-9.0$

Optirnurn: 30

Stagnant ond rumning water containing iron salts and

Optimum: 24

Limits: 5-40 


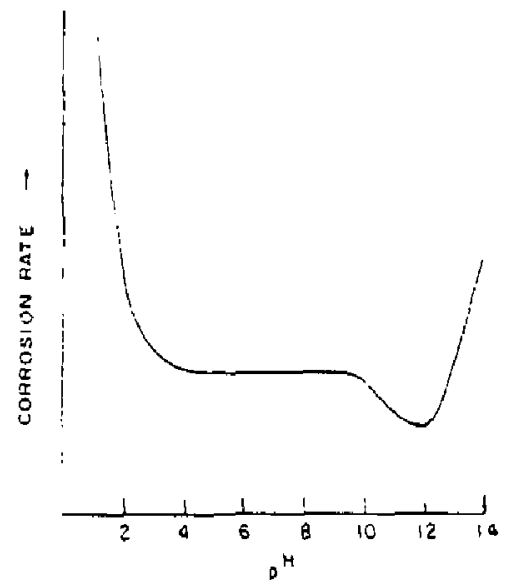

Figure 4. Variacion of corrosion race with the pH value.

\section{FIGURE E-2}

VARIATION OF CORROSION RATE WITH THE PH VALUE

1

$E-13$ 
changes as the corrosion reaction r.oceeds. Probobly the total soil acidity may be a better gouge. It has been found that, for a fixed amount of oxygen present in the soil, the rate of corrosion is proportional to the total acidity rather than to the $\mathrm{pH}$.

\subsection{TESTS AND CRITERIA FOR SOIL AGGRESSIVENESS}

Experience indicates that corrosion of metals in soils depends on a large number of interrelated parameters. The heteragenity of the soil and the complex nature of the corrosion process suggests that a single parameter would not give a good predictive value of the oggressiveness of the soil. However, on the basis of laboratory tests and field experience, many investigators in various countries hove attempted to formulate lestr that would measure a single or combination of par ameters to predict the corrosiveness of soils.

It wos found by preliminary tests and experience with buried metals, that in the case of ferrous metals, the corrosion rate did not depend significantly on the composition or heot treatment of the ferrous alloy. The corrosion rote was mainly dependent on the soil characteristics. Early investigations had also determined that, although the chemical properties played a major role in the corrosion process, they could not be used as a reliable measure of the soil corrosivity. Generally, the tests and criteria should be simple, relotively rapid, and capable of field use, and should give results predicting relative corrosion rates.

Some of the major criterio developed are listed below.

\subsubsection{RESISTIVITY}

Romanoff stated that the most reliable parameter for estimating the corrosivity of soils is its resistivity. ${ }^{31}$ The resistonce depends on the temperature, moisture content, dissolved salts, compactness of the soil and presence of inert moterial, l.e., all the major elements controlling the rate of corrosion. The resistance of the electrolyte is one of the main factors affecting the flow current associoted 
with corrosion. It is also a parameter that can be easily measured. Based on an extensive study in the United Stotes, of various metols buried all over the country, soil oggressiveness has been chorocterized by seporote resistivity ranges. This has been graphically shown for ferrous metals in Figure E-3.

The resistivity of the soil gives a rapid qualitative indication of the aggressiveness of the soil. A weokness of the resistivity procedure is that it indicotes neither the variations in aeration and $\mathrm{pH}$, nor the biological activity in the soil.

\subsubsection{RESISTIVITY AND pH}

The test method to estimate relative corrosiveness of the soil by combining the relative influences of the hydrogen-ion concentration $(\mathrm{pH})$ and the "minimum" resistivity of the soil establishes the relotive soil corrosivity by plotting these combined values on a chart, as shown in Figure E-4. It will be noted that the corrosion rote in alkaline soils $(\mathrm{pH}>7.0)$ is influenced much more by the resistivity than by $\mathrm{pH}$. In acidic soils the sorrosion is controlled by the combined effect of $\mathrm{pH}$ and resistivity of the soil. In the discussion of this figure the resistivity of the soil is dependent on the moisture content, and the resistivity will decreose to a minimum value as the moisture content iricreases and then increases again as more moisture is added. The resistivity would, therefore, be the minimum resistivity. It is expected that the total acidity would be a more dependable indicator than $\mathrm{pH}$. However, the feasibility of using the total acidity instead of $\mathrm{pH}$ hos not been established.

\subsubsection{RESISTIVITY AND REDOX POTENTIAL}

G. H. Booth and co-workers, ${ }^{34-36}$ on an extensive study of soil systerns in the Urited Kingdom recommended a criterion for the aggresiveness of soils: 


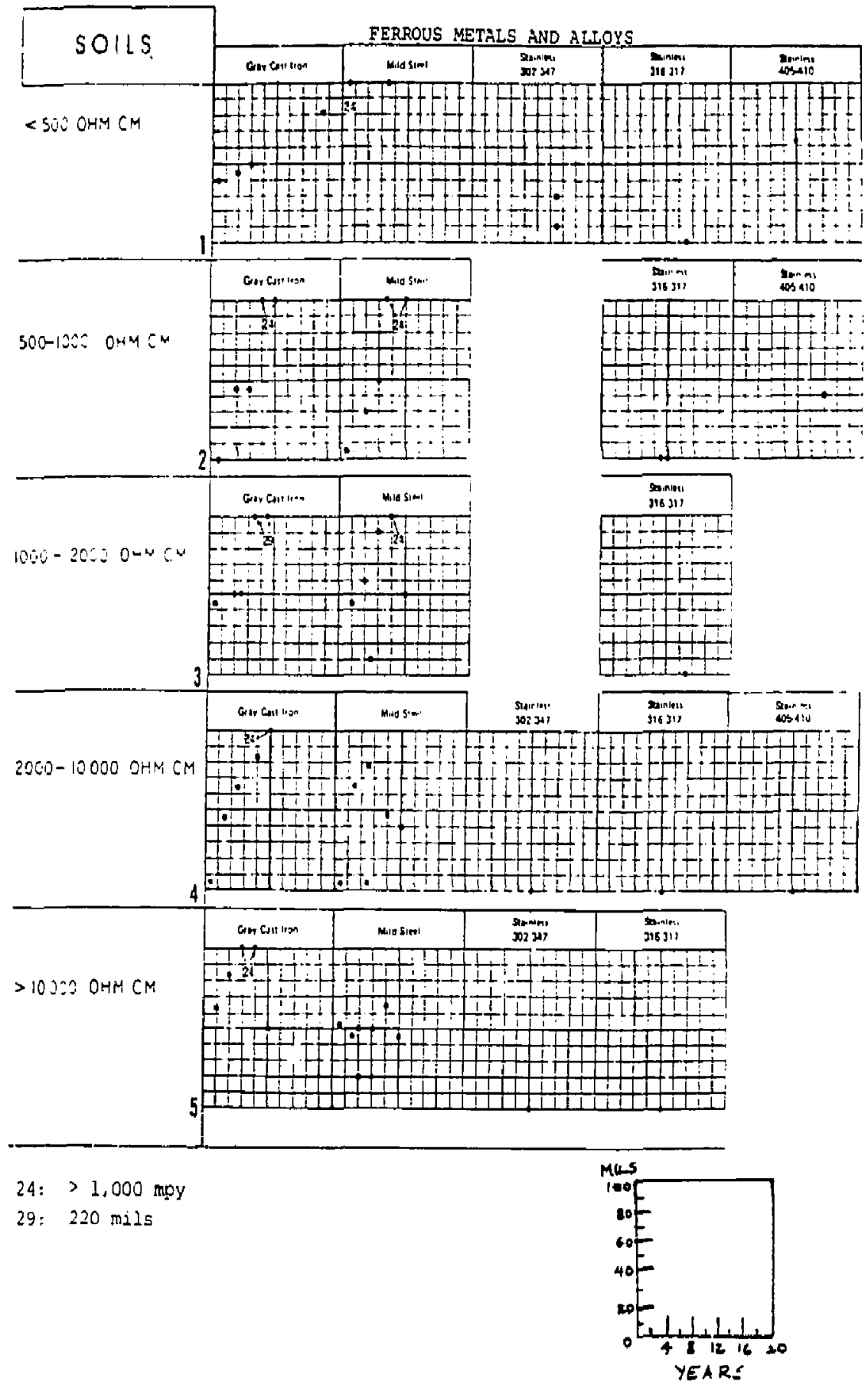

FIGURE E-3

MATRIX OF PIT DEPTH VERSUS YEARS OF EXPOSURE DEPICTING THE 5OIL CORROSION OF FERROUS ALLOYS FOR DIFFERENT RESISTIVITY SOILS ${ }^{17}$ 


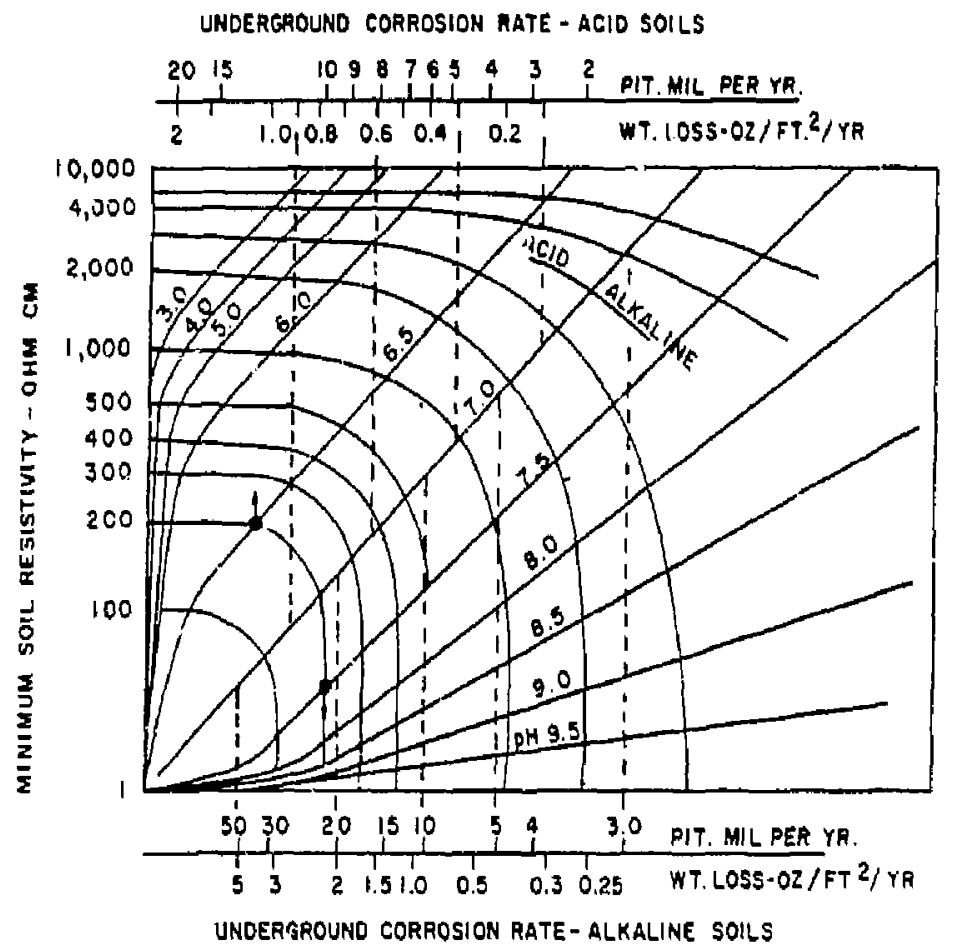

FIGURE E- 4

CHART FOR ESTIMATING CORROSION RATE OF STEEL PIPE ${ }^{2 !}$ 
Aggressive

Resistivity, $\mathrm{\Omega}-\mathrm{cm}$

and/or

Redox-potential at $\mathrm{pH}=7,(\mathrm{~V}(\mathrm{~N} . \mathrm{H}, \mathrm{E})$,

Borderline cases to

be resolved by:

Woter content $\% / \mathrm{w} / \mathrm{w}$
$<2,000$

$<0.400$

$<0.430$ if eloy or

$>0,430$ if cloy

The resistivity would generally give an indization of the uniform corrosion of metal while the redox potential would be indicative of the risk of bacterial corrosion. A summary of the results to support their criteria is given in Table E-3. It should be noted that the limiting value of $2,000 \Omega \mathrm{s}-\mathrm{cm}$ for the resistivity is in very close agreement with value suggested by Schwerdtfeger, ${ }^{36}$ and the value of $0.430 \mathrm{~V}$ as a critical volue of the redox potential approximates closely to the minimum value for non-aggressiveness put forword by Storkey and Wight, ${ }^{36}$ Table E-4, for ancerobic corrosion of iron in soils. In the borderline case the soil is considered aggressive if the water content is greater than 20 percent (the value at which 100 percent of the buried metal surfoce becomes electrochemicolly active.)

\subsubsection{POLARIZATION OF THE METAL ${ }^{21}$}

Since it was recognized that corrosion in soils is electrochemical in nature, many investigators attempted to measure the octual corrosion eurrents. The currents that are ossociated with corrosion depend not only on the resistivity of the soil, but also on the potential of the metal with respect to the adjocent electrolyte. The currents may also be suppressed by polarization films and corrosion products. Table E-5 gives a scole of the corrosiveness of soils based on electrical measurements and loss in weight of the anode material (metal to be tested). 
TALBLE E-3

PROPERTIES OF SOME SOHL IN THE UNIIED KINGDOM, THEIR MREDIC:TED ACGIRESSIVENESS, AIND IIHE MEASIJREO CORROSION RA IE OF MILD STEEL 34,35

\section{Description of Soll}

Fine loom, stones and chalk Fine sundy lonin

Brown clay

Fine lonm with fine grave

Fine loam

Heteragenous clay

in Light brown clay and ballost

$\frac{1}{0}$ Mixed clay and loam

Clay-sond mixture

Brown clay

1-lomogenous brawn cloy

Cluy

\begin{tabular}{|c|c|c|c|c|c|}
\hline No. & Site & $\begin{array}{l}\text { Resistivily, } \\
\text { (ohm-cm) }\end{array}$ & $\begin{array}{c}\text { Redox- } \\
\text { Potentiol, } \\
\text { Vot pl-1 = } 7 \\
\text { (1.J.t.E_. ? } \\
\end{array}$ & p+1 & $\begin{array}{c}\text { Water } \\
\text { Content } \\
(\%) \\
\end{array}$ \\
\hline $\mathbf{I}$ & Turville & 21,800 & 0.512 & 7.8 & 19.0 \\
\hline 2 & Ripley & 21,450 & 0.500 & 7.5 & 11.7 \\
\hline 3 & Brixton & 3,900 & 0.527 & 7.6 & 19.9 \\
\hline 4 & Teddington & 33,4000 & 0.460 & 4.0 & 80.3 \\
\hline 5 & Eversler & 17,100 & 0.528 & 6.7 & 14.5 \\
\hline 6 & Cricklewoor! & 2,100 & 0.543 & 7.5 & 23.5 \\
\hline 7 & Botony Bay & 19,200 & 0.527 & 5.6 & 15.6 \\
\hline 8 & Greenform & 1,500 & 0.490 & 7.5 & 25.5 \\
\hline 9 & Basildon & 2,800 & 0.365 & 7.5 & 26.5 \\
\hline 10 & Royleigh & 740 & 0.380 & $7+6$ & 25.3 \\
\hline 11 & Canvey Istond & 1,700 & 0.520 & 8.6 & 22.6 \\
\hline 12 & Broughtorn & 2,000 & 0.468 & 7.6 & 26.0 \\
\hline
\end{tabular}

Rate of

Corrosion

of Mild

Steel Afre

g/ $\left.\mathrm{dm}^{2} / \mathrm{dny}\right)$

Ferrous

Ferrous
Moterial

Non-aggressive

Non-oggressive

Non-aggressive

Non-oggressive

Mon-aggressive

No: iggressive

Non-aggressive

Aggressive

Aggressive

Aggressive

Aggressive

Aggressive \begin{tabular}{c}
1.7 \\
2.7 \\
3.1 \\
3.3 \\
3.5 \\
4.7 \\
11.8 \\
\hline 4.7 \\
6.3 \\
8.1 \\
16.9
\end{tabular} 
TABLE E-4

CLASSIFICATION OF CORROSIVENESS OF SOILS

BASED ON REDOX POTENTIAL MEASUREMENTS

TO DETERMINE THE ANAEROBIC CORROSION OF IRON ${ }^{36}$

Range of Soil Redox Potential

Below $100 \mathrm{mv}$

100 to $200 \mathrm{mv}$

200 to $400 \mathrm{mv}$

Above $400 \mathrm{mv}$
Classification of Corrosiveness

Severe

Moderote

Slight

Noncorrosive 


\begin{tabular}{|c|c|c|c|c|c|c|c|}
\hline \multicolumn{2}{|r|}{ Soil } & \multirow{2}{*}{$\begin{array}{l}\text { Resis- } \\
\text { tivity } \\
\text { at } \\
600 \mathrm{~g}\end{array}$} & \multirow{2}{*}{$\begin{array}{l}\text { Maxi- } \\
\text { mum } \\
\text { open } \\
\text { circuit } \\
\text { volt- } \\
\text { age }\end{array}$} & \multirow{2}{*}{$\begin{array}{c}\text { corzo- } \\
\text { sion } \\
\text { poten: } \\
\text { tialb }\end{array}$} & \multirow{2}{*}{$\begin{array}{c}\text { cutzent } \\
\text { at } \\
\text { cor- } \\
\text { rosion } \\
\text { po- } \\
\text { tentzal }\end{array}$} & \multirow{2}{*}{$\begin{array}{l}\text { Maxi- } \\
\text { mun } \\
\text { short- } \\
\text { circuit } \\
\text { cur- } \\
\text { rent }\end{array}$} & \multirow{2}{*}{$\begin{array}{l}\text { Loss of } \\
\text { weighte }\end{array}$} \\
\hline No. & Type & & & & & & \\
\hline & & $\begin{array}{l}\text { ohm- } \\
\mathrm{cm}\end{array}$ & $v$ & $v$ & ma & mid & $\left\{\begin{array}{c}\left(m g / c m^{2}\right) / \\
y r\end{array}\right.$ \\
\hline 1 & Docas clay & 62 & 0.31 & 0.34 & 2.72 & 2.19 & 1.475 \\
\hline$=$ & $B_{1} 12$ ings sile loammon.m.n.m. & 81 & .30 & .32 & 3.96 & 2.95 & 1,230 \\
\hline 3 & Unidentifled alkali soil-n-- & 263 & .38 & .29 & 2.55 & 2.20 & 1,230 \\
\hline 4 & 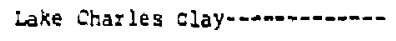 & 406 & .37 & .29 & 2.92 & 1.64 & 1,150 \\
\hline 5 & 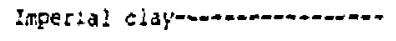 & 102 & .38 & .32 & 2.90 & 2.70 & 1,130 \\
\hline 6 & 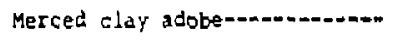 & 1,28 & .30 & .35 & 2.00 & 1.70 & 1,340 \\
\hline 7 & 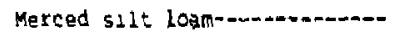 & 278 & .34 & .22 & 1.88 & 1.05 & 722 \\
\hline$E$ & 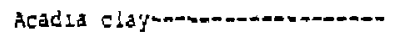 & 190 & .12 & .31 & 1.20 & .80 & 708 \\
\hline 9 & Fargo elay loammment......... & 350 & .12 & .37 & .78 & .55 & $59 \mathrm{C}$ \\
\hline 10 & Eresno fine sandy loam=..n... & 51 & .16 & $.2 \downarrow$ & 1.20 & .60 & 534 \\
\hline 11 & 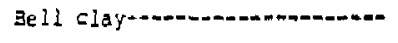 & 684 & .24 & .33 & .90 & .54 & 504 \\
\hline 12 & Unidentified soil-ne-n & 2,120 & .14 & .24 & .50 & .42 & 370 \\
\hline 13 & Allis silt loan-n- & 2,215 & .14 & .22 & .60 & .23 & $24 i$ \\
\hline 14 & Sunmit silt loamon. & 1,320 & .07 & .26 & .40 & .20 & 214 \\
\hline 15 & 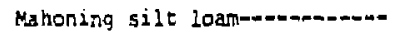 & 2,870 & .20 & .36 & .67 & .32 & 202 \\
\hline 16 & 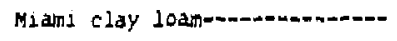 & 1,780 & .01 & .32 & .005 & .003 & 26 \\
\hline
\end{tabular}

- Potential (H scalẹ) between anode and cathode of corrosion cell on open circust.

b potentiol (H scale) at intersection of current-density-potential curves.

c calculated srom results in a 2-week run.

TABLE E-5

CORROSIVENESS OF SOILS AS̃ INDICATED BY ELECTRICAL MEASUREMENTS AND LOSS IN WEICHT OF ANOOES ${ }^{21}$ 


\subsection{MILD STEEL CONTAINER CORROSION DUE TO TRU WASTE FORM INTERACTIONS ${ }^{37}$}

TRU solid wastes are often solidified in 208-liter mild carbon steel drums or large carbon steel baxes. Container failure con result from either mechanical foilure or corrosion attack due to interoctions with the disposal environment or the waste. The previous section gave o review of the corrosion of mild steel in buriol environments. This section considers the corrosion of mild steel due to interactions with the waste form.

Three zones of contact occur between the waste form and metol container--the woste form in direct contact with the metal container; the free liquid and the container; and the container in contact with the vapor phase of the waste. These different zones could give different rates and types of corrosive attock. Cenerally there are two types of corrosian that can occur: uniform corrosion, that is the general thinning of the metal over the entire exposed area; and pitting, where the corrosion occurs of localized regions, while the rest of the metal is not attacked. Both types of corrosive attack hove been considered; however, pitting corrosion would generally be of greater importance since it leads to more rapid penetrotion of the container matericl.

In this investigation both mild steel samples and coupons obtgined from o 208-liter drum have been exposed to urea formaldehyde (UF) and cement solidified woste forms, two of the possible TRU waste forms and the form for which the most dato is ovailable. UF is generally found to have certain undesirable features, but was being proposed for hardling low-level woste from the ACNS reprocessing waste.

The fnllowing data have been taken from low-level radwoste studies ${ }^{37}$ and adopied and ore applicoble to the TRU waste defined previously. ${ }^{5}$ 
Toble E-6 presents a list of the waste formulations. These have been screened to be adaptable to TRU waste generated in the fuel cycle. These wastes were solidified and subject to leachants of salt water, groundwoter (Toble E-7) and distilled water. The mild steel canister composition is given in Table E- 8 (which is typical of a wide range of the mild steel TRU waste containers). Tobles E-9 through E-II present woste formulation and codes to interpret the extensive dato provided.

\subsection{TOTAL IMMERSION TESTS AND DATA 37}

Table E-12 summarizes the results of corrosion tests on mild steel samples exposed to the wastes (without any additions). The corrosion of mild steel in the powdered resin waste and the chemical regenerative waste is low (less than one mils per year). In all cases the type of corrosion was uniform with no localized pitting.

The result of exposure of mild steel and octual drum samples in the waste containing UF polymerization catalyst is summarized in Tables E-13 and E-14. With the addition of the solidification agent catalyst decreoses the $\mathrm{pH}$ of the waste solution and hence gives a much higher rate of corrosion of mild steel in all the waste solutions. In the case of the drum samples, initially there is a relativaly uniform removal of the zinc cooting and then corrosion of the mild steel. The corrosion of mild steel samples in the wastes plus cotalyst wos studied to determine the corrosiveness of aggressive electrolytes in solidified UF waste pockoges, since the liquid entropped in pores of the polymer matrix of solidified UF consists of this low pH solution. The addition of the catalyst (25 wt \% sadium bisulphate) the wastes lowers the $\mathrm{pH}$ of oll three waste solutions (to $\mathrm{pH}$ $\sim 2$ ) and in this acidic solution the mild steel is heavily ottuched (5-15 mils per yeor). Although the corrosion in all three wastes is high initially, in the powdered resin the corrosion rate decreoses to $\sim 3$ mils per year, while in the chemical regenerative waste the corrosion rote continues to be high over long exposure times. 
TABLE E-6

(CONT.)

\section{Decontamination Waste of A Forced Recirculation Evaporotor}

Material

Weight Percent

in Evaporator Bottoms, \%

Water

Nutek NT-700 d

80.0

EDTA

9.4

Citris Acid

5.0

Crud

5.0

Hydroulic Oil No. 2

0.2

Lubricating Oil No. 20

Temperoture

$\mathrm{pH}$

0.2

0,2

$77^{\circ} \mathrm{C}$

5

\section{Decontaringtion Woste of a Thin Film Evaporator}

Material

Water

Nutek NT-700

EDTA

Citric Acid

Crud

Hydraulic Oil No. 2

Lubricaling Oil No. 20

Temperature

$\mathrm{pH}$
Weight Percent

\section{in Evaporator Bottoms, \%}

The temperature and $\mathrm{pH}$ reported are typical yalues prior to solidification.

a Rohm and Haas Co., Philadelphia, PA 19105

b Ecodyne Corp., Union, NJ 07083

c Fine air cleaner test dust no. 1543094, AC Spark Plug Division, Generol Motors Corp., Flint, Ml 48556

d Nuclear Technolngy Corp., Amston, CT 06231 
TABLE E-7

\section{GROUND WATER LEACHANT COMPOSITION}

pH

conductivity, whe

6.2

130

Constituent

dissolved oxygen

chloride

totol phosphorus

total nitrogen

disşolved solids

copper

silver

lead

zinc

codmium

chromium

iron
Content, pom

9.4

18.1

$<0.05$

1.1

92

0.12

$<0.005$

0.004

0.045

$<0.009$

$<0.008$

0.061 
TABLE E-8

CHEMICAL COMPOSITION OF MILD STEEL

\begin{tabular}{lccc} 
Carbon Steel & & Als! 1010\% & Measured \% \\
\cline { 3 - 4 } Carbon & $0.10 \mathrm{max}$ & 0.06 \\
Manganese & $0.30-0.60$ & 0.32 \\
Phosphorus & $0.035 \mathrm{max}$ & 0.010 \\
Sulphur & $0.045 \mathrm{max}$ & 0.021 \\
Silicon & $0.10 \mathrm{max}$ & $<0.01$ \\
Nickel & - & $<0.01$ \\
Chromium & -- & $<0.01$ \\
Molybdenum & - & $<0.01$
\end{tabular}


I ABLË E-9

WASTE SOLIDIFICATION WITH UREA-FORMALDEHYDE

Type of
Waste
$-\begin{gathered}\text { Weight } \\ \text { Ratio } \\ \text { Waste to } \\ \text { U.F. }\end{gathered}$

Volume \%

of Sodium

Approximate Solidification

Time (min)
Pit of UF + Waste
defore Addition
of $\mathrm{NaHSO}_{4}$ SOLN.

8.0

5

2

8.0
$\mathrm{pH}$ of UF + Waste

After Addition of $\mathrm{NaHSO}_{4} \mathrm{SOLN}$.

3.1

2.0
1.7

2.4 
TABLE E-10

WASTE SOLIDIFICATION WITH PORTLAND TYPE II CEMENT

\begin{tabular}{|c|c|c|}
\hline Type of Waste & $\begin{array}{l}\text { Weight Ratio } \\
\text { Wuste to Cement }\end{array}$ & $\begin{array}{c}\text { Approximate } \\
\text { Solidificotion Time } \\
\text { (days) }\end{array}$ \\
\hline $\begin{array}{l}\text { Powdered } \\
\text { Resin }\end{array}$ & 1.8 & 4 \\
\hline $\begin{array}{l}\text { Chemical } \\
\text { Regenerative }\end{array}$ & 1.7 & 3 \\
\hline
\end{tabular}

$E-28$ 


\section{TABLEE-11}

NOMENCLATURE FOR THE VARIOUS TEST SOLUTIONS AND WASTE FORMS

$$
\text { ADDITION }
$$

\begin{tabular}{|c|c|c|c|c|}
\hline Iype of Waste & None ${ }^{(0)}$ & $\begin{array}{c}\text { Catalyst } \\
\text { (Sodium Bisulphate) } \text { (b) }^{(\text {b }} \\
\end{array}$ & $\begin{array}{c}\text { UREA- } \\
\text { Formoldehyde } \\
\text { with Catalyst (c) }\end{array}$ & $\begin{array}{l}\text { Portland } \\
\text { Type II } \\
\text { Cement (c) }\end{array}$ \\
\hline $\begin{array}{l}\text { Powdered } \\
\text { Resin }\end{array}$ & $A$ & D & $G$ & J \\
\hline $\begin{array}{c}\text { Chemical } \\
\text { Regenerotive }\end{array}$ & 3 & $E$ & $\mathrm{H}$ & $k$ \\
\hline
\end{tabular}
(a) Refers to waste solution as prepared
(b) Indicative of free standing water in UF waste porkages
(c) Solidified woste forms 


\begin{tabular}{|c|c|c|c|c|c|c|c|c|c|}
\hline soin & SNMPLE & $\begin{array}{l}\text { Trme } \\
\text { line }\end{array}$ & $\begin{array}{c}\text { WEtcius loss } \\
\text {-ge }\end{array}$ & 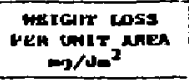 & $\begin{array}{l}\operatorname{mante} \\
\text { mey }\end{array}$ & $\begin{array}{l}\text { conunsion } \\
\text { ploptet }\end{array}$ & $\begin{array}{l}\text { colung } \\
\text { Pat } \\
\text { cast. }\end{array}$ & $\begin{array}{l}\text { sino } \\
\text { Pat }\end{array}$ & IDIARES \\
\hline \multirow[t]{3}{*}{ n } & 20 & $\begin{array}{r}24 \\
114 \\
192 \\
10\end{array}$ & $\begin{array}{l}7.0 \\
3.4 \\
9.9 \\
0.2\end{array}$ & $\begin{array}{r}7.35 \\
29.40 \\
0.79 \\
0.39\end{array}$ & $\begin{array}{l}3.45 \\
0.78 \\
0.91 \\
0.71\end{array}$ & 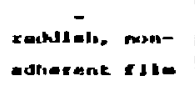 & $\begin{array}{l}x \\
x \\
x \\
x\end{array}$ & & \\
\hline & 2 & i11 & 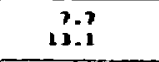 & $\begin{array}{l}20.55 \\
32.04\end{array}$ & $\begin{array}{l}0.93 \\
0.56\end{array}$ & 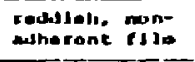 & $x$ & & \\
\hline & $\mathbf{J}$ & 360 & 16.3 & 64.73 & 0.79 & $=$ & $x$ & & \\
\hline \multirow[t]{3}{*}{$"$} & 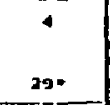 & $\begin{array}{r}24 \\
214 \\
192 \\
10 \\
\end{array}$ & $\begin{array}{l}0.3 \\
3.3 \\
1.0 \\
1.2\end{array}$ & $\begin{array}{l}3.50 \\
11.11 \\
19.07 \\
4.77\end{array}$ & $\begin{array}{l}0.65 \\
0.35 \\
0.34 \\
0.54 \\
0.44\end{array}$ & 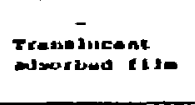 & $\begin{array}{l}x \\
x \\
x \\
x\end{array}$ & & \\
\hline & 5 & $\begin{array}{l}148 \\
312\end{array}$ & $\begin{array}{l}7.6 \\
1.6\end{array}$ & $\begin{array}{l}10.31 \\
18.27\end{array}$ & $\begin{array}{l}\text { a. } 31 \\
\text { o. } 21\end{array}$ & 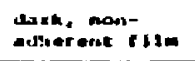 & $\mathbf{x}$ & & \\
\hline & . & $36 n$ & 9.5 & 37.74 & 4.46 & Pouk. mon- & $\pi$ & & \\
\hline \multirow[t]{3}{*}{ c } & 3v: & $\begin{array}{c}24 \\
114 \\
1,2 \\
140\end{array}$ & $\begin{array}{r}0.7 \\
10.4 \\
41.0 \\
10.3 \\
\end{array}$ & $\begin{array}{r}14.36 \\
160.49 \\
194.65 \\
40.92 \\
\end{array}$ & $\begin{array}{l}6.11 \\
1.60 \\
3.12 \\
3.14\end{array}$ & 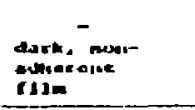 & 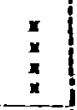 & & \\
\hline & II & $\begin{array}{l}111 \\
312\end{array}$ & $\begin{array}{l}14.7 \\
73.2\end{array}$ & $\begin{array}{l}177.53 \\
296.02\end{array}$ & $\begin{array}{l}5.40 \\
2.45\end{array}$ & 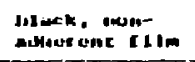 & 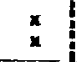 & & \\
\hline & * & 360 & 40. 6 & 320.10 & 3.90 & & " & & \\
\hline
\end{tabular}

TABLE E-12

CORROSION OF MILD STEEL SAMPLES IN THE THREE TYPES OF WASTES"

* Disregard waste solution $C$ (boric acid) since these types of waste are not expected to be TRU contarninated. 


\begin{tabular}{|c|c|c|c|c|c|c|c|c|}
\hline sors & SAnrt.: & $\begin{array}{l}\text { TIME } \\
\text { lie }\end{array}$ & wh:leirr towis & 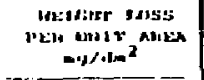 & $\operatorname{lonht}_{-1-x}$ & 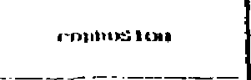 & 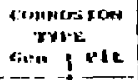 & пËASTKS \\
\hline \multirow[t]{3}{*}{ J" } & 31 & $\begin{array}{l}21 \\
111 \\
192 \\
111\end{array}$ & $\begin{array}{r}11.4 \\
+7.9 \\
56.1 \\
0.6\end{array}$ & $\begin{array}{l}13.25 \\
190.28 \\
113.24 \\
11.14\end{array}$ & $\begin{array}{l}4.27 \\
\text { s. 3u } \\
1.10 \\
1.12\end{array}$ & 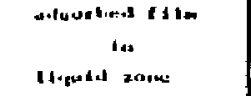 & 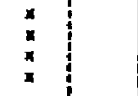 & 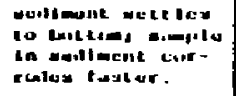 \\
\hline & 11 & 14 & $\begin{array}{l}47.1 \\
\% .3\end{array}$ & 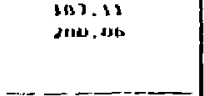 & $\begin{array}{l}5 .(-\infty) \\
3-11\end{array}$ & 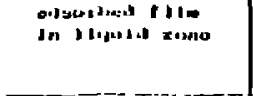 & $x$ & 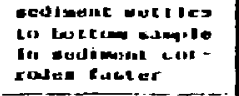 \\
\hline & 12 & $14+11$ & u2. 1 & 324.51 & 4.1.tk & 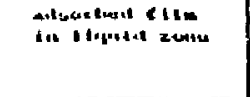 & k & 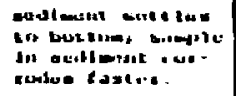 \\
\hline \multirow[t]{3}{*}{ :: } & 13. & $\begin{array}{r}34 \\
114 \\
192 \\
14\end{array}$ & $\begin{array}{r}26.9 \\
166.9 \\
204.0 \\
79.2\end{array}$ & 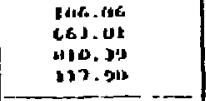 & $\begin{array}{l}19.3) \\
20.32 \\
13.16 \\
10-76 \\
\end{array}$ & 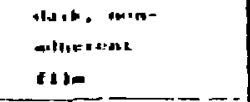 & 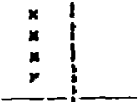 & \\
\hline & 14 & 114 & $\begin{array}{r}130.1 \\
274.1 \\
\end{array}$ & $\begin{array}{r}506.87 \\
2,4010.07\end{array}$ & $\begin{array}{l}10.15 \\
12.84\end{array}$ & dut: oper- & $x$ & 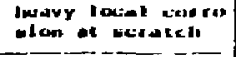 \\
\hline & 15 & 14ill & 112.4 & 4122.05 & 16.1 & 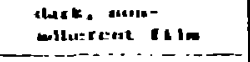 & $x$ & $\rightarrow$ \\
\hline \multirow[t]{3}{*}{ •" } & $\begin{array}{l}11, \\
11 \\
-\ldots .\end{array}$ & $\begin{array}{r}24 \\
114 \\
192 \\
14\end{array}$ & $\begin{array}{r}31.6 \\
31.2 \\
701.2 \\
111.4\end{array}$ & 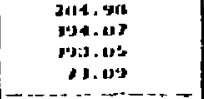 & $\begin{array}{c}17.45 \\
0.23 \\
11.31 \\
6.64\end{array}$ & 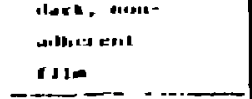 & $\begin{array}{l}x \\
x \\
x\end{array}$ & \\
\hline & $\because$ & $\begin{array}{l}1.14 \\
112\end{array}$ & $\begin{array}{l}2+1.4 \\
121.13\end{array}$ & 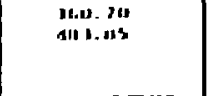 & IU. 91 & 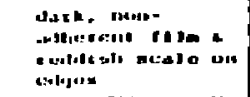 & x & \\
\hline & III & ル" & 1111 & 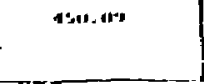 & S. AnI & 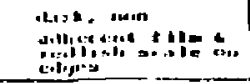 & x & . \\
\hline
\end{tabular}




\begin{tabular}{|c|c|c|c|c|c|c|c|c|}
\hline SOI.N & SAMP1.E & $\begin{array}{l}\text { TIHF: } \\
\text { hra }\end{array}$ & $\underset{\substack{\text { WEIS } \\
\text { mgIT IOSS }}}{ }$ & $\begin{array}{l}\text { WEI I GIT LNSS } \\
\text { PEH INIT ANEN } \\
\text { ny, } / \mathrm{dm}^{2}\end{array}$ & $\begin{array}{l}\text { mite: } \\
\text { nquY }\end{array}$ & $\begin{array}{l}\text { connosision } \\
\text { rinciouct }\end{array}$ & $\begin{array}{c}\text { CORROSICw } \\
\text { arpe } \\
\text { Gein : IT }\end{array}$ & nements: \\
\hline (s) & $\begin{array}{l}313 \\
230 \\
1913\end{array}$ & $\begin{array}{l}193 \\
359 \\
360 \\
690\end{array}$ & $\begin{array}{l}34.0 \\
59.1 \\
55.7 \\
29.3\end{array}$ & $\begin{array}{l}269.20 \\
150.03 \\
431.60 \\
614.51\end{array}$ & $\begin{array}{c}- \\
2.07 \\
2.70 \\
1.90\end{array}$ & $\begin{array}{l}\text { yel low rast in } \\
\text { sesme regions. } \\
\text { uniform yel low } \\
\text { isl, film. } \\
\text { yel lowisl. real } \\
\text { filin }\end{array}$ & $\begin{array}{l}x \\
x \\
x\end{array}$ & 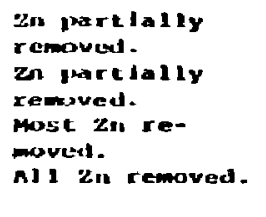 \\
\hline $\mathbf{E}$ & $\begin{array}{l}\text { 18 } \\
20 \\
913\end{array}$ & $\begin{array}{l}193 \\
359 \\
360 \\
690\end{array}$ & $\begin{array}{r}43.4 \\
64.2 \\
72.6 \\
106.2\end{array}$ & $\begin{array}{l}136.15 \\
197.55 \\
562.65 \\
1123.05\end{array}$ & $\begin{array}{l}- \\
3.12 \\
3.51 \\
2.65\end{array}$ & $\begin{array}{l}- \\
\text { redull glu film: } \\
\text { dark film. } \\
\text { dark film. }\end{array}$ & $\underset{x}{x}$ & 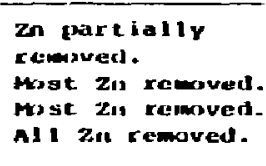 \\
\hline$F$ & $\begin{array}{l}291 \\
1011 \\
1711\end{array}$ & $\begin{array}{l}193 \\
159 \\
1601 \\
600]\end{array}$ & $\begin{array}{l}152.2 \\
175.7 \\
\text { in2.5 } \\
206.1\end{array}$ & $\begin{array}{l}1210.30 \\
1161.60 \\
1214.30 \\
1597.211\end{array}$ & $\begin{array}{l}- \\
11.53 \\
11.113 \\
5.15\end{array}$ & $\begin{array}{l}\text { daxk film. } \\
\text { dark film. } \\
\text { black film. } \\
\text { lojack film. }\end{array}$ & \begin{tabular}{l|l}
$x$ \\
$x$ \\
$x$ & $x$ \\
non-unterm \\
corrosion.
\end{tabular} & 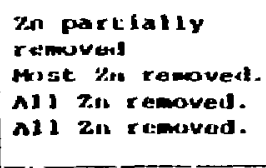 \\
\hline
\end{tabular}

CORROSION OF DRUM SAMPLES IN THE THRFE TYPES OF WASTES

$$
\text { WITH CATALYST* }
$$

(25 WT. \% SODIUM B!SULPHATE) 
Tables E-15 and E-16 give the results for exposure to the solidified UF waste forms for mild steel and drum somples respectively, In solidified UF woste nackages, the corrosion rate of mild steel ( $1-3$ mils per year) lies between that measured in the waste solution and in the waste plus catalyst. This low corrosion rate is attributed to the solid electrolyte, which consists of a porous polymer motrix with the waste liquid entrapped in the pores. Although the entropped woste liquid is acidic and would generally give rise to o high corrosion rate, the polymer matrix inhibits the removal of corrosion products fram the surface of the metal and the diffusion of corroding species to the metal surface. Thus, the metal reacts with the solution in contact with it and forms a corrosion product film on the surfoces of the metal which decreases the rate of subsequent corrosion.

In drum sample fests, it was found that most of the protective zinc cooting on the inner surfoce is lost after o few days of exposure to the environment ( $\sim 25$ days in the solidified UF waste packoges and $\sim 12$ days in the liquid waste plus catalyst). Therefore, the zinc cooting does not provide any long term protection for the mild steel drum, wnich is consistent with the generol observotion that zinc coatings are not good cathodic protectors in acidic solutions. Also, once the zinc cooting is removed, the rate of corrosion of base steel is similar to the corrosion rote of mild steel samples exposed to the same solutions.

\subsection{EXPOSURE TO VAPOR PHASE}

Tables $E-17$ and $E-18$ summarize the corrosion of mild steel and drum samples respectively for exposure to the vapor phase of the solidified UF waste packages. Experiments on corrosion in the vapor phase of waste package were conducted such that they simulated the conditions in the drum, that is, a closed yessel was used allowing no extra oxygen from the atmosphere to enter the cell. The corrosion in the vapor phase is much higher than in the solid electrolyte ( $\sim$ six mils per year in the vapor phase to one mils per year in the solidified UF waste), and the corrosion is lacal in nature. The corrosion starts at localized points and 


\begin{tabular}{|c|c|c|c|c|c|c|c|c|c|}
\hline Sot.. & SAMIRTEE & $\begin{array}{l}\text { TIME } \\
\text { lirs }\end{array}$ & $\begin{array}{l}\text { WEIGH'l' LOSS } \\
\text { Ins }\end{array}$ & 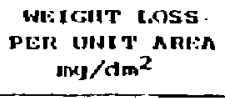 & $\begin{array}{l}\text { rente: } \\
\text { mey }\end{array}$ & $\begin{array}{l}\text { controsion } \\
\text { phomictr }\end{array}$ & 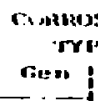 & it & RI:MA FKS \\
\hline G & $\begin{array}{l}19 \\
20 \\
21\end{array}$ & $\begin{array}{l}21 \% \\
6,70 \\
1075\end{array}$ & $\begin{array}{l}13.0 \\
35.7 \\
56.5\end{array}$ & $\begin{array}{r}51.64 \\
141.02 \\
224.45\end{array}$ & $\begin{array}{l}0.99 \\
0.925 \\
0.92\end{array}$ & $\begin{array}{l}\text { - } \\
\text { non-adherent } \\
\text { t1lm } \\
\text { blank nons } \\
\text { aclleercilt f11m }\end{array}$ & $\begin{array}{l}x \\
x \\
x\end{array}$ & & \\
\hline 11 & $\begin{array}{l}22 \\
2.3 \\
24\end{array}$ & $\begin{array}{r}240 \\
670 \\
1075\end{array}$ & $\begin{array}{r}18.6 \\
39.0 \\
110.6\end{array}$ & $\begin{array}{r}73.89 \\
154.93 \\
.439 .36\end{array}$ & $\begin{array}{l}1.35 \\
1.00 \\
1.79\end{array}$ & $\begin{array}{l}\text { black. mon- } \\
\text { balherent t tim } \\
\text { black film }\end{array}$ & $\begin{array}{l}x \\
x \\
x\end{array}$ & & $\begin{array}{l}\text { ptetimy on one } \\
\text { stde of sample. }\end{array}$ \\
\hline $\mathbf{I}$ & $\begin{array}{l}25 \\
26 \\
27\end{array}$ & $\begin{array}{r}240 \\
670 \\
1075\end{array}$ & $\begin{array}{r}71.6 \\
113.6 \\
169.6\end{array}$ & $\begin{array}{l}282.05 \\
530.73 \\
673.74\end{array}$ & $\begin{array}{l}5.15 \\
3.46 \\
2.75\end{array}$ & $\begin{array}{l}\text { red filmon one } \\
\text { side, paliou on } \\
\text { other. } \\
\text { redi, tight film. } \\
\text { spotty red aisr } \\
\text { black filin. }\end{array}$ & $\begin{array}{l}x \\
x\end{array}$ & $x$ & 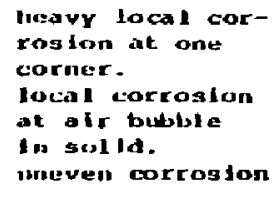 \\
\hline
\end{tabular}

0
0
0
0
0
0

TABLE E-15

CORRDSION OF MILD STEEL SAMPLES IN THE TH-IFEE TYPES OF WASTES IN SOLIDIFIED UREA-FORMALDEHYDE" 


\begin{tabular}{|c|c|c|c|c|c|c|c|c|}
\hline 501.t3 & SAMTLE & $\begin{array}{l}\text { lime } \\
\text { liss }\end{array}$ & $\begin{array}{l}\text { WLI IGII' IOSS } \\
\text { Iniss }\end{array}$ & 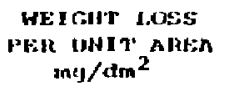 & $\begin{array}{l}\text { Int'E } \\
\text { mry }\end{array}$ & $\begin{array}{l}\text { CORROSI ON } \\
\text { P'RODUC:T }\end{array}$ & $\begin{array}{l}\text { CORPOS ION } \\
\text { IYYEE } \\
\text { hen PIt }\end{array}$ & IuEmRxs \\
\hline$c:$ & $\begin{array}{l}\text { An } \\
5 n \\
615 \\
7 n\end{array}$ & $\begin{array}{l}306 \\
675 \\
1000 \\
1100\end{array}$ & $\begin{array}{r}21.3 \\
42 .: \\
72.7 \\
111.1\end{array}$ & $\begin{array}{l}165.011 \\
320.60 \\
602.11 \\
915.24\end{array}$ & $\begin{array}{l}2.21 \\
2.13 \\
2.64 \\
3.40\end{array}$ & $\begin{array}{l}\text { gray film. } \\
\text { tidin yellow } \\
\text { film. } \\
\text { yellow flith. } \\
\text { yellow flim. }\end{array}$ & $\begin{array}{l}\mathbf{x} \\
\mathbf{x} \\
\mathbf{x} \\
\mathbf{x}\end{array}$ & 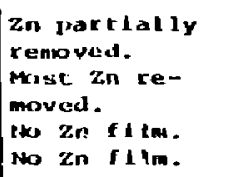 \\
\hline 11 & $\begin{array}{l}1413 \\
1213 \\
2013\end{array}$ & $\begin{array}{r}360 \\
697 \\
1032 \\
12013\end{array}$ & $\begin{array}{l}26.1 \\
51.7 \\
72.6 \\
72.5\end{array}$ & $\begin{array}{l}202.20 \\
400.68 \\
56.2 .65 \\
554.13\end{array}$ & $\begin{array}{l}2.46 \\
2.52 \\
2.39 \\
2.02\end{array}$ & $\begin{array}{l}\text { spotty reddisl, } \\
\text { fim. } \\
\text { spotty redilish } \\
\text { black film. } \\
\text { red filmwitl } \\
\text { black spots } \\
\text { red flyn witl. }\end{array}$ & $\begin{array}{l}x \\
\text { non-unt form } \\
\text { corrosiou- } \\
\text { unon-uniform }\end{array}$ & $\begin{array}{l}\text { partial zn re- } \\
\text { moved. } \\
\text { Most Zn re- } \\
\text { moved. } \\
\text { No Zn fllm. } \\
\text { no zn film. }\end{array}$ \\
\hline I & $\begin{array}{l}220 \\
100 \\
1 \mathrm{in} \\
3 \mathrm{~min}\end{array}$ & $\begin{array}{r}356 \\
697 \\
1032 \\
1200\end{array}$ & $\begin{array}{l}55.5 \\
75.2 \\
96.1 \\
112.1\end{array}$ & $\begin{array}{l}430.13 \\
5112.00 \\
744.70 \\
06.19 .70\end{array}$ & $\begin{array}{l}5.30 \\
1.66 \\
1.16 \\
1.17\end{array}$ & $\begin{array}{l}\text { yel low film. } \\
\text { yellow and } \\
\text { black film. } \\
\text { yellow and } \\
\text { black film. } \\
\text { liark yel low } \\
\text { amt black } \\
\text { fllin }\end{array}$ & $\begin{array}{l}x \\
x \\
\text { mon-uniform } \\
\text { corrosian } \\
\text { non-woiform } \\
\text { corrosion } \\
\end{array}$ & $\begin{array}{l}\text { Host Zu re- } \\
\text { moved. } \\
\text { No fin film. } \\
\text { Ho Zn film } \\
\text { Now zin film. }\end{array}$ \\
\hline
\end{tabular}




\begin{tabular}{|c|c|c|c|c|c|c|c|c|c|}
\hline & Solst & SNMPLE & $\begin{array}{l}\text { TIME } \\
\text { hXS }\end{array}$ & $\begin{array}{l}\text { HEIcirt IOSS } \\
\text { mus }\end{array}$ & $\begin{array}{l}\text { HEIGIT LOSS } \\
\text { PES UHST AREA } \\
\text { mg/dme }\end{array}$ & $\begin{array}{l}\text { RNTE } \\
\text { myYy }\end{array}$ & 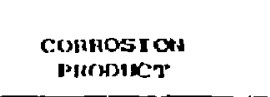 & $\begin{array}{l}\text { COHROS ION } \\
\text { IYPE } \\
\text { cen PIt }\end{array}$ & RET:ZAK:3 \\
\hline & 6 & $\begin{array}{l}A T-1 \\
M r-2 \\
n r-3\end{array}$ & $\begin{array}{l}166 \\
405 \\
744\end{array}$ & $\begin{array}{r}90.3 \\
120.6 \\
143.1\end{array}$ & $\begin{array}{r}761.00 \\
1021.73 \\
1136.93\end{array}$ & $\begin{array}{r}20.53 \\
11.01 \\
5.67\end{array}$ & $\begin{array}{l}\text { spotty black } \\
\text { scale } \\
\text { gpotty, brittla } \\
\text { adherent. rusty } \\
\text { black film. } \\
\text { black (partiajly } \\
\text { rust color) } \\
\text { spotty scale. }\end{array}$ & $\begin{array}{l}x \\
x\end{array}$ & $\begin{array}{l}\text { E: } \\
\text { E }\end{array}$ \\
\hline$\prod_{1}$ & nt & $\begin{array}{l}A T-4 \\
A T-5 \\
A T-6\end{array}$ & $\begin{array}{l}160 \\
407 \\
796\end{array}$ & $\begin{array}{r}54.0 \\
133.0 \\
179.1\end{array}$ & $\begin{array}{r}429.03 \\
1063.04 \\
1422.95\end{array}$ & $\begin{array}{r}11.15 \\
4.53 \\
8.27\end{array}$ & $\begin{array}{l}\text { spotty black } \\
\text { rist spots. } \\
\text { black scale } \\
\text { oll over. } \\
\text { black scale } \\
\text { all over. }\end{array}$ & $\begin{array}{l}x \\
x \\
x\end{array}$ & $\begin{array}{l}E \\
E \\
E\end{array}$ \\
\hline & 1 & $\begin{array}{l}A \mathrm{~d}-7 \\
A r-B\end{array}$ & $\begin{array}{l}160 \\
407\end{array}$ & $\begin{array}{l}61.6 \\
04.2 \\
77.0\end{array}$ & $\begin{array}{l}489.41 \\
6611.97 \\
611.77\end{array}$ & $\begin{array}{r}12.71 \\
6.66 \\
3.48\end{array}$ & 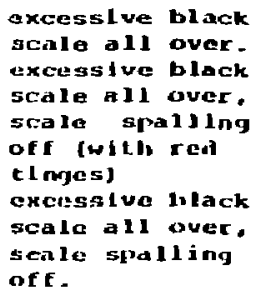 & $\begin{array}{l}x \\
x\end{array}$ & $\mathbf{E}$ \\
\hline
\end{tabular}

CORROSION OF MILD STEEL SAMPLES IN TH IE VAPOR PHASE OF THE THREE TYPES OF IVASTES IN SOLIDIFIEO UHEA-FORMALDEHYDE 


\begin{tabular}{|c|c|c|c|c|c|c|c|c|c|}
\hline SOIN & SAMPLE & $\begin{array}{l}\text { TIStE } \\
\text { lirs }\end{array}$ & $\begin{array}{c}\text { WEIGIT } \\
\text { mujs }\end{array}$ & 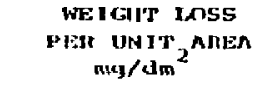 & $\begin{array}{l}\text { jente: } \\
\text { migy }\end{array}$ & $\begin{array}{l}\text { Cornosion } \\
\text { Phomsire? }\end{array}$ & Cor & $\begin{array}{l}\text { ION } \\
\text { PIt }\end{array}$ & ITLAMRKS \\
\hline G & $\begin{array}{l}330 \\
3210 \\
310\end{array}$ & $\begin{array}{r}355 \\
697 \\
1032\end{array}$ & $\begin{array}{l}39.04 \\
63.84 \\
99.92\end{array}$ & $\begin{array}{r}57.66 \\
941.93 \\
1461.64\end{array}$ & $\begin{array}{l}7.46 \\
6.22 \\
6.50\end{array}$ & $\begin{array}{l}\text { red flaky fllm. } \\
\text { red scale with } \\
\text { blick spokg. } \\
\text { red f black } \\
\text { spotty adlierent } \\
\text { film. }\end{array}$ & $x$ & $\begin{array}{l}x \\
x \\
x\end{array}$ & \\
\hline 11 & $\begin{array}{l}34 B \\
35 n \\
36 n\end{array}$ & $\begin{array}{r}335 \\
673\end{array}$ & $\begin{array}{l}32.84 \\
53 \cdot 41 \\
59.22\end{array}$ & $\begin{array}{l}479.34 \\
207.46 \\
869.04\end{array}$ & $\begin{array}{r}12.74 \\
5.40 \\
3.19\end{array}$ & $\begin{array}{l}\text { rust color } \\
\text { flaky film. } \\
\text { rust color } \\
\text { fliky film } \\
\text { wtti adherent } \\
\text { black spots. } \\
\text { red and black } \\
\text { adtie rent film. }\end{array}$ & & $\begin{array}{l}x \\
x\end{array}$ & \\
\hline $\mathbf{I}$ & $\begin{array}{r}390 \\
378 \\
3 n n\end{array}$ & $\begin{array}{l}340 \\
677 \\
1012\end{array}$ & $\begin{array}{l}25.62 \\
26.90\end{array}$ & $\begin{array}{l}377.79 \\
433.32\end{array}$ & $\begin{array}{l}5.16 \\
2.90\end{array}$ & $\begin{array}{l}\text { ligbt rust } \\
\text { color flaky } \\
\text { film. } \\
\text { ruet color } \\
\text { flaky cilm with } \\
\text { acilierent black } \\
\text { sints. }\end{array}$ & & $x$ & $\begin{array}{l}\text { Samile foll Into } \\
\text { clectralyte. }\end{array}$ \\
\hline
\end{tabular}

㲾

TABLE E- 18

CORROSION OF DRUM SAMPLES IN THE VAPOR PHASE OF THE THHREE TYPES OF WASTES IN SOLIDIFIFD UREA-FORMALDEHYDE* 
the number of locol zones increase until they cover the complete surface of the metal. The corrosion is caused by the condensation of aggressive moisture in the upper zone of the corrosion cell. The condensotion took place as a result of doily temperature fluctuation in the laboratory. As the temperature falls, the relative humidity increases and when the relative humidity is 100 percent the moisture condenses on the metal surface. It has been shown that temperature fluctuations of two to five degrees con cause condensation in a closed chamber. Fluctuations like these are not inconsistent, and perhaps larger fluctuations would be experienced in the field.

The condensed liquid forms o thin electrolyte film on the metal surface and since this thin film is only a weok inhibitor to diffusion of oygen from the air to the surface, it gives rise to high corrosion rotes, similar to otmospheric corrosion. Atmospheric corrosion proceeds moinly by oxygen depolarization and since the thin electralyte gives easy access for the axygen to the metol surface, it increases the rote of corrosion. On the other hand, these electrolyte films ore more easily saturated with corrosion products which retard the anodie process. These two competing factors control the rate of corrosion. Although condensation begins on a smooth and clean metol surface only at 100 percent relative humidity, on a surfoce covered with corrosion products the condensation con take place in the pores of the corrosion at much lower relative humidity and this again increases the rate of vopor phose corrosion.

The local noture of the corrosion in the vapur phase is due to two factors. The condensation tokes place as droplets on the surface and, therefore, the corrosion is initioted of these sites. Secondly, the inclusions of impurities such as chlorides and sulphides in the vapor promote non-uniform corrosion. 


\subsection{PARTIAL IMMERSION TESTS}

The results of mild steel and drum samples portially immersed in the solidified UF waste form are given in Tables $E-19$ and E-20, respectively. These tests simulate the corrosion conditions in the barrel, that is the metal is in contact with the solidified UF waste form, the free liquid above the waste form and the vapor phase. In the immersed region of the sample, there is no adherent film, only general corrosion of the moterial. The upper region of the sample, which is exposed to the vapor phase, hos a dark spotty scale and, as seen in the cleaned somple, this corresponds to locolized pitting of the metal. At the interface where the metal is exposed to the free liguid, a loose red corrosion product is formed and one observes the deepest penetration of the metal in this zone. A loose corrosion product forms of the free liquid-vopor interface and as it accumulates, free liquid seeps upward by capillory action exposing more metal to this aggressive environment. In this region, the moteriat loss is non-uniform; general thinning of the sample with some local pitting occurs. Corrosion is most ropid in the free liquid region.

The partially immersed tests qualitotively show every type of corrosion that can be encountered in the woste pockage. The corrosive attack on the portion of the metal exposed to the solidified UF and on that exposed in the vapor phase is similar to the tests performed for these environments alone. The maximum corrosion, however, takes place ot the interface where the metal is exposed to the free liquid from UF waste forms. The corrosion in the free liquid probobly approoches that experienced in the waste plus cotalyst since both these solutions hove a low $\mathrm{pH}$.

Partial immersion tests were also performed with mild steel in cement waste forms as listed in Table E-2l. Solidified cement is a poor electrolyte and, therefore, one would expect low corrosion rotes in the solidified cemert waste package. It is observed that generally the corrosion in cement is indeed 


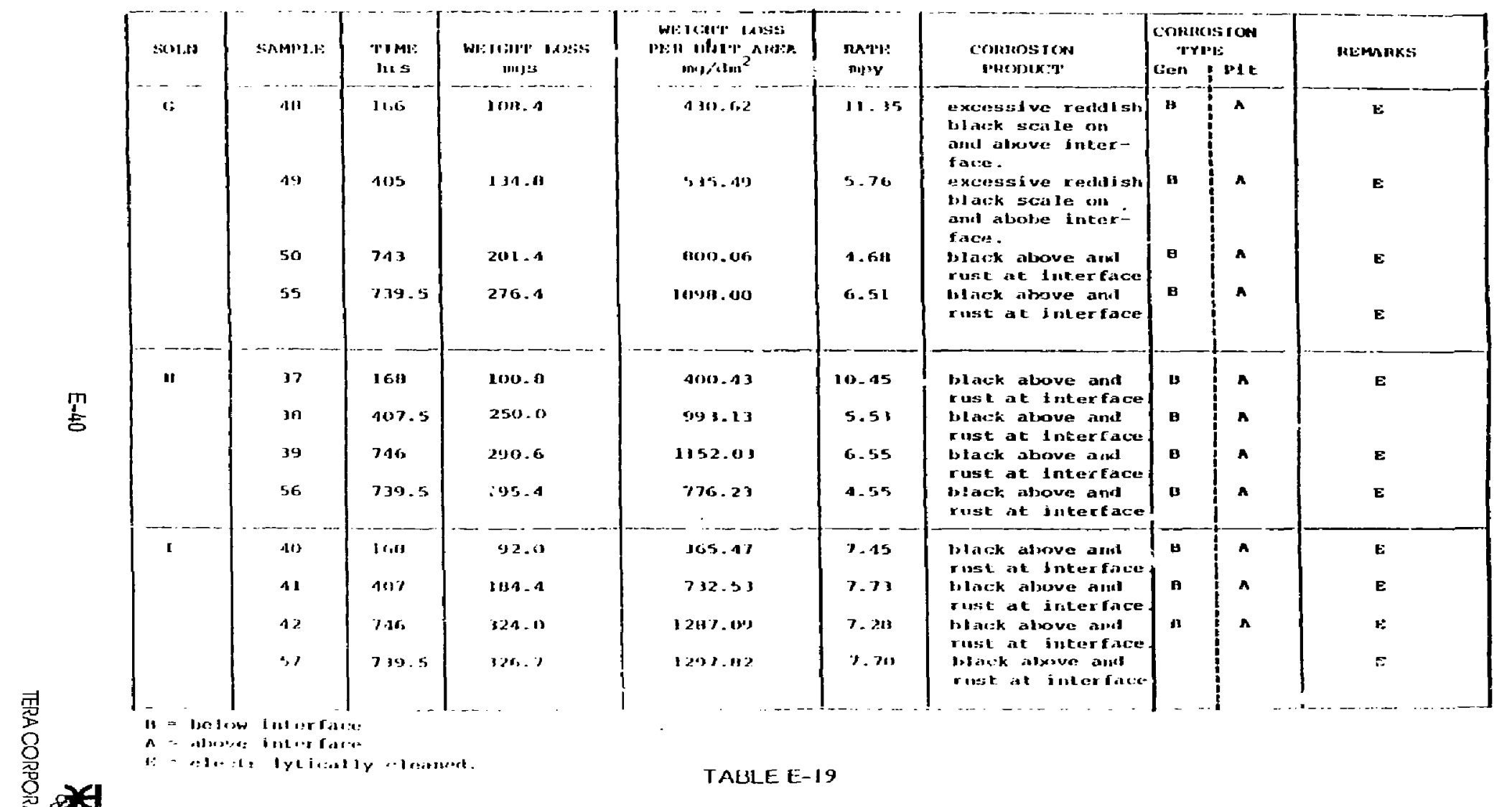

CORROSION OF MILO STEEL SAMPLES PARTIALLY IMMERSED IN THE THR'TE TYPES OF WASTES IN SOLIDIFIED UIEA-FORMALDEHYDE* 


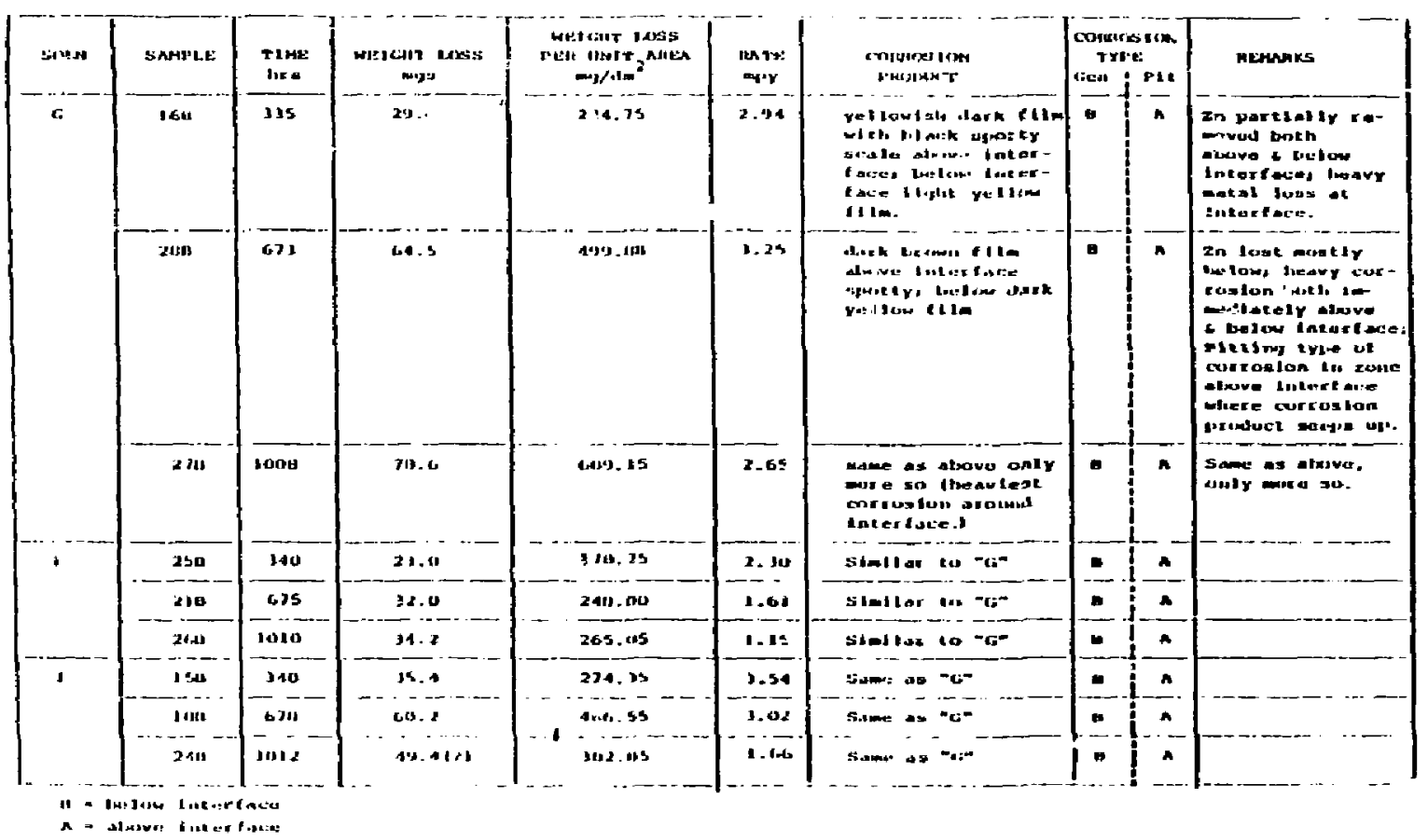

TABLE E-20

CORROSION OF DRUM SAMPLES PARTIALLY IMMERSED IN THE TI-HREE TYPES OF WASTES IN SOL IDIFIED UREA-FORMALDEHYDE* 


\begin{tabular}{|c|c|c|c|c|c|c|c|c|}
\hline $\begin{array}{l}\text { sold } \\
\text { solat }\end{array}$ & $\begin{array}{l}\text { SAMPIIE: } \\
\text { SAAM1IJ: }\end{array}$ & $\begin{array}{l}\text { Pent: } \\
\text { TIME: } \\
\text { ine }\end{array}$ & WI:Msur Mess & 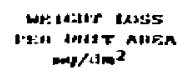 & MnTw & 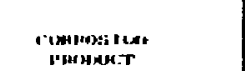 & 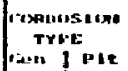 & REMARS \\
\hline J & 41 & 202 & $\begin{array}{l}\text { G2.01 } \\
\text { 1.40.3 } \\
1.11 .4\end{array}$ & $\begin{array}{c}245.41 \\
3589.31 \\
3,46.11 \\
?\end{array}$ & $\begin{array}{l}0.16 \\
x .70\end{array}$ & 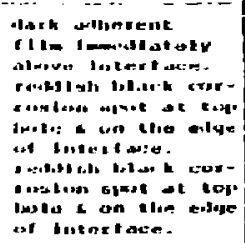 & & 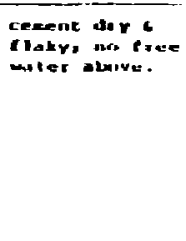 \\
\hline$\kappa$ & 51 & 1079 & 21.0 & $\begin{array}{l}\text { 94.5S } \\
\text { SH. Wu }\end{array}$ & $\begin{array}{l}\text { D. nos } \\
\text { D. }\end{array}$ & 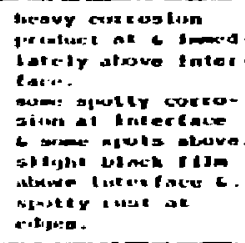 & & 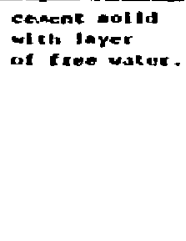 \\
\hline I. & 32 & 1416 & sit. It & 201. & o. 14 & 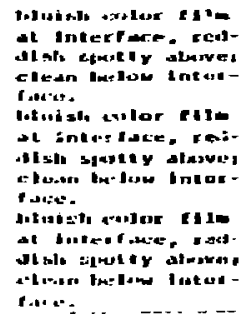 & & 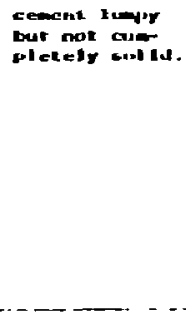 \\
\hline
\end{tabular}

TABLE E-2I

CORRCSION OF MILD STEEL SAMPLES PAIRTIALLY IMMERSED IN THE THREE TYPES OF WASTES IN SOLIDIF IED CEMENT ${ }^{*}$ 
negligible. There are only localized spots on the metal which are attacked, such os the edge of the sample or at some defect on thample. In this cose, the solidification process has a tremendous effect on the attack of the metal. In the powdered resin waste form which solidifies quickly and forms a dry flaky monolith, the corrosion is restricted to the edges of the sample. In the chemical regenerative waste form, which had a loyer of free liquid on the top of the solidified cement, the corrosion is restricted to the section of metal exposed to the free liquid. However, this free liquid is not aggressive (since it has a neutral $\mathrm{pH}$ ) and does not give rise to much corrosion in the vapor phose. 
APPENDIX F

PROPOSED REGULATORY CHANGES:

REQUIREMENTS FOR TRANSPORTATION

OF RADIOACTIVE MATERIALS 


\subsection{NTERNATIONAL REGULATORY ASPECTS}

The mojor regulolory motter concerning radiooctive waste transportation which remoins pending in the U.S. is odoption of amendments based on the 1973 IAEA standards in Safety Series No.6, "Regulations for the Safe Transport of P wiooctive Materials," 1973. The U.S. and Canodo ore the last remaining mijjor countries who hove not yet finalized and implemented their adoption of the 1973 standords. All of the mojor international tronsport organizotions and conventions, such os IMCO, IATA, RID, ADR, and ICAO, by now have completed such adoption.

The reosons for the deloy in the U. 5. are many, voried, and complex, but the principal ones include:

- The need and logic of coordinated, joint regulatory actions by NRC and DOT to amend 49 CFR and 10 CFR pt the same time (presently under way os discussed I Section 4.0); and

- The need to hoid off publication until after the DOT's recent consolidotion of its surfoce, air, and woter regulotions for hazardous materials into a single volume.

The following discussion wili review a few of the noteworthy differences which can be expected in the DOT proposol os compared to the IAEA regulations per se. As a point of clarification, the "1973" revised IAEA regulations ore now octually comprised of the text of the 1973 Sofety Series No. 6 as it was issued in 1974, plus a list of "minor drofting changes" issued in 1975, and onother list of so-called "90-day amendments," issued by the IAEA in December 1977. The IAEA hos republished a "1973 Revised Sofety Series No. 6, 1978 Printing," incorporating these changes. These also hove been taken into occount in the expected NRC and DOT proposals.

\subsection{LOW SPECIFIC ACTIVITY (LSA) AND LOW-LEVEL SOLID (LLS) MATERIALS}

In the DOT picposal to adopt 1973 IAEA standards, there are expected to be certain differences between those proposals and the IAEA requirements. These 
differences will deal moinly with requiring Type A packagings for both LSA and LLS, in lieu of "strong industrial packagings" in the cose of LSA or pockogings meeting the United Notions performonce requirements in the cose of LLS moterials. Needless to say, however, interpretive questions on the current LSA requirements hove been voluminous, and adoption of the IAEA requirements in their existing form could serve to heighten the confusion on such matters.

\subsection{DISCONTINUANCE OF SPECIFICATION 55 PACKAGINGS}

Also to be contoined in the DOT Notice will be o proposal to discontinue the use of DOT Spec. 55 pockogings, os Spec. 55s, one year after the effective date of an adopted omendment. This action is consistent with DOT's earlier amendment in Docket HM-111, 2,3 which terminote the use of new Spec. 55 pockogings after March 31. 1975. The Spec. 55 is a lead or uronium steel-encased shielded packaging which has been in the regulations for many years, octually pre-doting the odoption by the U.S. of the 1967 IAEA standards.

Its use has been limited since 1968 to domestic shipments only of limited Type $B$ quontities (up to 300 curies) of special form moterials, even though many Spec. 55 designs do not necessarily quality as Type 8 . Continued usoge of ony particular Spec. 55 ofter the effective date of any amendments would be contingent upon their being requalified as a Type $B$ packoge and certified by INRC. During the post severol yeors, many manufacturers of new Spec. 55 s. particulorly gammo radiography devices, hove been toking steps to quolify such designs os Type $B$.

\section{I.3 OXIDIZING OR PYROPHORIC RADIOACTIVE MATERIALS}

The DOT proposol will olso contain provisions for pockoging of specific lowlevel, non-fissile rodioactive moteriols which olso exhibit on added hazard characteristic af being an oxidizer or a pyrophoric material. 


\subsection{NEW LAEEL FORMAT}

Bosed on O U.S. recommendation, one of the "90-day amendments" recently adopted by IAEA is a revised lebel format for the three categories of "RADIOACTIVE" labels. The principol effect of these omended labeis is to ollow for more spoce for the written entries on the "contents" and "act i.ity" lines as well as less "clutter" in the transport index box by shifting of the verticol red strips over the right of the word "RADIOACTIVE."

\subsection{TYPE A PACKAGING FOR LIQUIDS}

In onother very significont "90-doy amendment," olso bosed on o U. S. proposal, the IAEA hos adopted revised requirements for Type A packaging for liquids. It is essentiolly the some os the current U.S. requirements odopted in Docket HiM-1II on December $31,1974 .^{3}$ This colled for a packoging system which must meet o 30-foot drop test and include obsorbent materiais or a double conlainment system. The IAEA version differs somewhat in that an option for Jouble contoinment or use of absorbents is provided for packoges in which the liquid volume exceeds 50 cubic centimeters. This is especially oppropriate to the present SMivi proctice.

\subsection{ALLEVIATION OF INCOMPATIBLE U. S.IINTERNATIONAL REQUIREMENTS}

Obviously, the existing situation wherein current U.S. regulations ore bosed on 1967 IAEA stondards, with the rest of the world's bosed on 1973 stondards, is not the mast desirable. It is olso obvious that this only presents real problerns in the cose of internationol shipments and not domestically. Recognizing that completion of the expected rulemoking may take some time yet, two actions were recently token to alleviate problems of incompotible U.S. regulations with the other internotional regulations. In a recent rulemaking in Docket HNi-150, a provision was inserted into the DOT regulations permitting foreign Type $A$ and LSA packages to be imported into the U. S. when such pockoges have been limited in accordance with the content limitotions found in 1973 IAEA stondards. 
With respect to certificates of competent authority for Type $B$ and fissile materials, the DOT and NRC staffs hove recently effected o working agreement whereby the NRC staff will evaluate selected packoge designs on a case-by-cose basis ogoinst the equivolent IAEA criterio which ore expscted to be odopted into IO CFR 71. With such svoluations, DOT will then be able to reissue IAEA certificotes ogainst the 1573 IAEA stondords.

\subsection{FORMAT}

The majority of the proposed changes to appear in the DOT Notice ore editoriol in nature. From the standpoint of format, however, a substantial change is contemploted. The Notice will propose to incornornte, in part, o new plan of the hazardous materials regulations, adopting o new "Part 127" which will centrolize oll of the shipper requirements presently locoted in 49 CFR Ports 173.389 to 173.399. Eoch subport of Port 127 will be "roughly" equivolent in content 10 the eight sections of IAEA Sofety Series No. 6. 


\section{U. 5. REGULATORY ASPECTS}

\subsection{CONSOLIDATION OF THE HAZARDOUS MATERIALS RECULATIONS}

In 1976, the Moferials Transportotion Bureov of the Deportment of Tronsportotion pubished what may be the most extensive and significant amendments to the Hozordous Materials Regulotions in probably the last half-ceitury. These onendments, referted to as Docket HM- 112,5 involve o consolidotion of the regulations for the oir, woter, roil, and highwor modes into o single volume, Title 49 of the Code of Federal Fegulations. Prior to this time, and throughout history, the regulotions had been codified in three separote volumes of the Codes. This raconsolidation has been a tremendous aid and simplificotion to both shippers and carriers in facilitoting their understanding, use of, and complionce with the hoz ordous materials regulations.

Included in the HM-112 amendments me many other motters of significance, such os the creation of four new elossifications for hazardous moteriols io reduce special problems reloted to air ond water tronsport; new uniform multin modal vehicle placarding requirements; a standardization of the format for shipping poper descriptions; and the listing of many moteriols by specifie nome, rethr thon generic clossificotion. Although the chonges in HWi-l/z reloting to radionctive materials are few in number, it is important to point those few out. They include:

- A revision to the rodiotion dose rate criterio for the use of the Rodioactive Yellow II gack oge latel. Whereos the previous limits were $0.5 \mathrm{mrem} / \mathrm{hr}$ ot 3 (transport index) and a surface dose rate of $10 \mathrm{mrem} / \mathrm{hr}$, those limits hove been roised to $1,0 \mathrm{mrem} / \mathrm{hr}$ of $3^{\prime}$ and $50 \mathrm{mrem} / \mathrm{hr}$ of the pockoge surfoce.

- An exponsion of the elements of information required for inclusion on the shipping pape: destription for rodiouctive materials shipments.

- A revision of the proper shipping name listings for the generic (i.e., "n.0.5. or not otherwise specified") listings for podicoctive moterials. 
- New separate listirigs by nome for enriched and nonenriched uronium hexafluoride, acknowledging its dual hazard properties of being both o radicoctive and corrosive moterial.

- A revision of the vehicie plocords for rodiooctive moteriols, odopting the railrood-oriented diamond shape for oll modes, utilizing for the first time the standard radiation symbol on the placard.

\subsection{MISCELLANEOUS CHANGES RELATING TO RADIOACTIVE MATERIAL, DOCKET NO. HM-III}

A major regulatory docket concerning radicoctive materials was issued by the Deportment as a Notice of Propased Rulemoking in Docket HM- $111^{2}$ on October 25, 1973, under the caption, "Miscellaneous Proposals Reloting to Rodioactive Moterials." In this proposed Notice, o number of omenoments, based on experience since the mojor regulatory revision of Januory 1969 (HM-2), were proposed. These proposols were published as final amendments on December 31 , $1974 .^{3}$

\subsection{MONITORING OF RADIOACTIVE PACKAGES BY AIR CARRIERS}

A Notice was issued by the Department on December 11, 1975, under Docket $H N_{1}-131,6$ proposing to require oircraft operators to periorm certain inspections and monitoring of radiooctive materiais shipments. This proposol essentially replaced on earlier provision which hod been finolized by the FAA on February 4, 1975, which was to have become effective on January 1, 1976. Both the eorlier provision, which was revoked on December $11,1975,{ }^{7}$ and the $H N_{i}-|3|$ proposal would hove involved the imposition of specific requirements for oir corriers to perform radiation surveys on all pockoges of radioactive moterials tendered to them by shippers. On July 21, 1977, the DOT withdrew its Notice in Docket $\mathrm{HM}-131$, eiting its reosons in the preomble to the withdrowol not ice. 


\subsection{REQUIREMENTS FOR CARRIAGE OF RADIOACTIVE MATERIAL BY AIRCRAFT}

On July 21, 1977, DOT issued a proposal ${ }^{9}$ to odopt certain changes to the requirements for aircraft carrioge of rodioactive material (Docket HM-152). These proposols were bosed essentially on recommendations made previously by the AEC (now NRC) to the Federal Aviotion Administrotion. Among the possible proposed changes which would be bosed on those recommendations are:

- Establishment of separate limits for amounts of radiooctive moteriol ollowed to be carried on cargo-only gircroft.

- A reduction in the moximum ollowable tronsport index from 10.0 to 3.0 for a pockage on possenger-corrying aircroft.

- A revision in the separation distance tables for stowage of pockoges on oircraft.

- Other revisions in the stowoge rules for radiooctive packoges.

- Provisions for combinations of rodiooctive pockoges in shipping unit overpocks.

A substantiol number of public comments have been received on $\mathrm{HN}_{1}-152$. These are presently under stoff considerotion prior to odoption of ony finol amendments.

\subsection{FUTURE REGULATORY PROPOSAL ON TRANSPORT WORKERS}

In caoperation with NRC and several states, o number of studies heve been carried out over the past several years to obtain dato an radiation exposure to fransport workers; i.e., camiers, during the routine hondling of rodicactive packoges. Generally, these studies have indicated that in the majority of cases radiotion exposures to tronsport workers are at levels well below those which are considered to be permissible to members of the general public. In o few cases, however, such os speciolized corriers or freight forworders, the levels of exposure hove been estimated to approoch or slightly exceed those values. In 
order to oddress this motter, the DOT plons to issue o Notice of Proposed Rulemoking which will be intended to impose "rodiotion-worker" iype requirements for rodiotion protection on those speciolized carriers or freight iorwarders handling substantial volumes of radiooctive materiols pockoges.

\subsection{RELATIONSHIP OF DOT REGULATIONS TO OTHER LANS}

As a result of Section $112^{10}$ of the Public Low $93-633^{7}$ the Secretary of Transportation was provided with statutory authority to expressly preempt any requirement of o state or political subdivision which is "inconsistent with" ony requirement of the fat or any regulations issued under the Act. However, the Act also provides a mechanism by which a state or political subdivision may obtain outhority from the Secretary to mointain requirements which are inconsistent.

The DOT subsequently reissued "Its Hazardaus Moteriols Regulations in $49 \mathrm{CFR}$ to be under the Act, and published procedures to implement Section $112{ }^{12}$ Both omendments became effective on Januory 3, 1977, and together rendered Section!!2 effective os to 49 CFR Ports 171 to 179.

One major inconsistency ruling hos now been issued by DOT on April 4, 1978. ${ }^{13}$ In this, the DOT ruled that Section 175.111 of the New York City Health Code, os amended Jonuary 15, 1976, prohibiting tronsportation of certain rodioactive moterjals in and through New York City, is not inconsistent with requi"ements of the Act or with regulotions issued to date unde- the Act. A request for on inconsistency ruling on the New York City Health Code hod been submitted to DOT on Morch 1, 1977, by Associated Universities, Inc., Upton, Long Island, New York. In issuing its ruling on that request, the DOT onnounced its intent to commence rulemoking to consider the need for routing requirements under the Act for highway corricge of hazardous materiols. The DOT also expressed its concern over several aspects of the New York City requirement. 


\subsection{NRC ENVIRONMENTAL STATEMENT}

A significant oction hos been token recentiy by $N R C^{14}$ in the issuance of o "Final Environmental Stotement on Transportation of Rodiocctive Material by Air and Other Modes." The formal document is designoted as NUREG-0170, bearing the same title. This action is part of o current NRC rulemoking proceeding announced by NRC on June 2, 1975. Although the stotement was directed of oir tronsportation, other tronsport mades were consiciered in light of the Notional Environmental Policy Act of 1969. The stotement is intended to be generic in nature, ossessing the impact from all tronsportation, not just that associoted with o particulor rule chonge. The results of this proceeding and NUREG-0170 ore expected to comprise o bosic resource document which is relevant to both, NFC and DOT regulations for the safe transport of radionctive moteriois. 


\subsection{OTHER ISSUES AND PROBLEMS}

\subsection{RAIL TRANSPORT OF SPENT NUCLEAR FUEL AND WASTES}

During the past two years, there hove been two separate proceedings before the Internstote Commerce Commission (ICC) involving "flogouts" from turiff provisions on the handling of rail shipments of spent fuel and wastes. Aiter lengthy proceedings and hearings, the ICC has ruled, in eoch of the coses, ordering concellotion of the "flogouts" from the tariffs. In a third and related proceeding, the nuclear industry and the Department of Energy filed formal complaints with the ICC against certain eastern railroads who had held thernselves out not to be cormmon corriers of irrodiated spent fuel, In this case also, the ICC issued a suling against the roilroods' position.

\subsection{RADIOLOGICAL EMERGENCY RESPONSE PLANNING FOR TRANSPORT INCIDENTS}

The NRC and DOT undertook earlier this year a joint study of the odequocy of existing requirements for transportation of low-level radiooctive materials. This study follows o highway accident in September 1977 in eostern Colnrado in which a large quantity of uranium concentrate (yellow coke) wos spilled, necessitating on extended clean-up involving state, locol, corrier and shipper resources.

The subject of emergency response flanning for nuclear transport incidents has evolved as an important issue in the public forum. Pecent incideris, such os the Colorado "yellow cake" spill and the derailment of a freight troin corrying several uranium hexafluoride cylinders near Rockingham, North Corolina, in March 1977 hove served to heighten the issue and raise questions on the need for coordinated emergency response plonning. On December 24, 1975, ${ }^{16}$ the Federal Preparedness Agenc\%, General Services Administration, published a Notice entitled, MRodiological Incident Emergency Response Planning; Fixed Focilities and Transportation, Interagency Responsibilities." The purpose of this Notice wos to provide public information concerning the general course and method by which certain radiological incident emergency response plonning activities ore

$\mathrm{F} \cdot 10$ 
carried ow by the concerned federol ogencies. This Notice reploced on earlier Notice of Jenuary 24, 1973, which dealf with interagency planning for rodiological emergencies of fixed focilities. The new Notice extends such plonning activities to include tronsportation, os well as fixed focilities and stotes that the Department of Transportation is responsible for:

- Providing guidelines in cooperation with NRC ond other Federal ogencies; and consistent with NRC guidance, for the development of that portion of state and local emergency plans pertaining to transportation involving rodicoctive materiols as described in the purpose portion of this stotement.

- Assistance to stote and local governments in emergency planning for such transportation incic'snts.

Thus for, the interogency octivities under the Notice hove brought obout several noteworthy accomplishments, including the issuonce of a guidance monual on development of state emergency response plans for tronsportation relofed incidents, as weil os development and implementotion of programs of operational training in radiological emergency response plonning. The DOT's plans for this year include the develop ant of a proctical guidance manual on hondling tro usport accidents and the initiation of the development of a training course for errergency services personnel dealing specifically with handling nuclear transport accidents. This will serve as a supplement to a 20 -hour course which hos been already developed on handling of all iypes of hazardous moterials iransport accidents. 


\subsection{PRESENT STATUS OF DOTNRC RULEMAKING ACTIVITIES}

Both the NRC and DOT have substantially increased their activities in the area of rodioactive moterial transportation in 1979. These include the issuance of IE Bulletin 79-19 on August 10,1979 and the proposed ruismoking, relating to changes in NRC and DOT rules for radioactive woste packaging and tronsportotion, of August 16, 1979 and August 17, 1979 (Federal Register, Vol. 44, No. I50, p. 47966 and Vol. 44, No. 161, p. 48234-48257, respectively).

The IE Bulletin addressed problems with radwoste solidification, packoging and transportation and noted 53 problems in an audit of 43 recent waste shipments. The bullet in required that licensees audit their current rodwaste tronsportation practice, develop new p. ocedisres for waste manogement and transportation, initiote an auditable troining program in the area of waste packaging and tronsportation and provide informotion relotive to plont rodwaste generation rates and waste dispssal. In addition the entire practice of shipping bulk water is severely impocted by the questions of whether or not liquid radwaste is generated and how it is soliufied.

The proposed rulemaking dealing with NRC and DOT requirements for transportation of radioactive waste was discussed in Appendix $E$. 


\section{REERENCES}

1. IMCO - Inter-Governmental Moritime Consultative Organizotion

IATA - International Air Tronsport Organizotion

RID - European Agreement for Corrioge of Dangerous Goods by Roil

ADR - European Agreement for Corriage of Dongerous Goods by Rood

ICAO - Internotional Civil Aviotion Orgonizotion

2. Federal Register, Vol. 38, No. 205, p. 29483, October 25, 1973, Docket HM-lll, "Miscellaneous Proposols Reloting to Rodiogetive Materiols."

3. Federal Register, Yol. 39, No. 252, 0. 45238, December 31, 1974, Docket HM-III, "Radiooctive Moterials, Miscellaneous Amendments,"

4. Federal Register, Vol. 43, No. 52, p. 10917, March 16, 1978, Docket Hf.1-150, "Radiooctive Moterial Imported into the United Stotes."

5. Federal Recister, April 15, 1976, Part III "Consolidation of Title 14, Port 103, and Title 46, Port 146, in Title 49, 4IFR 15792, Dockets $H M-103 / 112$.

6. Federal Register, Docket HM-131, Notice No.75-10, 40FR57688, December 11, 1975. "Proposed Inspection and Monitoring Requirements for Radiooctive Materiols."

7. Federal Register, Docket No. 13668, Amendment No. 10j-26, 40FR57667, December 11, 1975, "Carriage of Rodiooctive Material," 14 CFR Part 103.

8. Federgl Register: Vol. 42, No. 140, p. 37426, July 21, 1977, Docket $H|M-| 3 \mid$.

9. Federal Register, Vol. 42, No. 140, D. 37427. July 21, 1977, Docket HM-152, Notice No. 77-6, "Corrioge by Aircruft - Requirements for Rodiooctive Moterials."

10. Public Law 93-633, 49U5C 1811 .

11. Federol Register, Docket HM-134, March 3, 1976, Notice No. 76-2, 4IFR9188, 14 CFR Part 103, 46 CFR Fatts 64 to 146, 49 CFR Ports $|7|-179$.

12. Federal Rosister, Vol. 41, No. 176, p. 38167, September 9, 1976, Docket HM-138, "Preemption and Enforcement Procedures."

13. Inconsistency Ruling IR-1, April 4, 1978, issued by DOT, Rejearch and Special Progroms Directorote, Moteriols Tronsportation Bureou. 
14. Federol Register, Vol. 43, No. 17, p. 3368, Jonuary 25, 1978, Nuclear Regulotory Commission, "Radionctive Moterial- Pockoging and Transportation by Air, Environmentol Stotement."

15. Public Low 94-79, August 9, 1975, and Public Low 94-187, December 31, 1975.

16. Federal Register, December 24, 1975, 40FR59494, General Services Administration, Federal Preporedness Administration, "Radiological Incident Emergency Response Planning; Fixed Facility and Tronsportotion, Interogency Responsibilities." 


\section{APPENDIX G}

DEPARTMENT OF TRANSPORTATION REGULATIONS (EXCERPTS)

PERTAINING TO

TYPE A WASTE CONTAINERS 


\subsection{CRITERIA}

The Specification 7A requirements (CFR49 178.350). This specification is given below:

\section{Subpart $k$ - Specifications for Ceneral Pockaging}

178.350 Specification 7A; General Pockaging, Type A. (Amd. 178-1, 33 F.R. 14935, Oct. 4, 1968)

178.350-1 Generol Requirements

d) Eoch packaoing must meet all applicable requirements of 173.24 of this chapter.

$176.350-2$

a) Each packaging must be so designed and constructed that it meets the standards for Type A packaging (see 173.389(j) and 173.398(b) of this chopter.) (Amd. 178-I, 33 F.R. 14935, Oct. 4, 1968)

\subsection{0-3 Marking}

a) Marking on the outside of each packoging as follows: "USA DOT 7A type A" and "Radioactive iVaterial."

b) Morking to conform with 173.24 of this chapter (And. 178-1, 33 F.R. 14935, Oct. 4, 1968).

Sections 173.24, 173.38\%(j), 173.393 and 173.398(b) are given below. 


\subsection{3 .24 STANDARD REGUIREMENTS FOR AL PACKAGES}

(a) Each package used for shipping hazardous materials under this subchapter shall be so designed and constructed and its contents so limited, that under conditions normally incident to transportation -.

(1) There will be no significait release of the hazoroous materials to the enviranment;

(2) The effectiveness of the packaging will not be subsizntially reduced; and

(3) There will be no mixture of goses or vopors in the pockage which could, through any credible spontaneous increase uf heat or pressure, or through on explosion, significa:tly reduce the effectiveness of the pockaging.

(b) Viaterials for which detailed specifications for pockoging ore not set forth in this part must be securely packaged in strong, tight packages meeting the requirements of this section.

(c) Packaging used for the shipment of hozardous materials under this subchapter shall, unless otherwise specified or exempted therein, meet all of the following design und construction criterio:

(I) Each specification contoiner must be marked as follows:

(i) In on unobstructed area with letters and numerals identifying the container specificotion (e.g., DOT-IA, DOT-17E-304HT, DOT.23G40). See $178.0-2$ of this subchapter.

(ii) The nome and address or symbol of person making the mark specified in porogroph $(c)(1)(\mathrm{i})$ of this section. Symbol letters, if used, must be registered with the MTB-TSC. Duplicote symbols are not author ized.

(iii) The markings must be stampeu, embossed, burned, printed, or otherwise marked on the pockaging to provide adequate occessibility, permanency, and controst so os to be readily apporent and understood. 
(iv) Unless otherwise specified, letters and numerols must be of least "s inch high.

(v) Packoging which does not comply with the applicable specification listed in Parts 178 and 179 of this subchapter must not be marked to indicate such compliance (see 178.0.2 and 179.1 of this subchopter).

(2) Steel used shall be low-carbon, commercial quality steel. Stainless, open hearth, electric, bosic oxygen, or other similar quality steels ore acceptoble. Steel sheets of specified gouges sholl comply with the following:

\begin{tabular}{|c|c|c|}
\hline $\begin{array}{c}\text { Gouge } \\
\text { No. }\end{array}$ & $\begin{array}{l}\text { Nominal } \\
\text { thickness } \\
\text { (inches) }\end{array}$ & $\begin{array}{l}\text { Minimum } \\
\text { thickness } \\
\text { (inches) }\end{array}$ \\
\hline $\begin{array}{l}12 \\
13 \\
14 \\
15 \\
16\end{array}$ & $\begin{array}{l}0.1046 \\
0.0897 \\
0.0747 \\
0.0673 \\
0.0598\end{array}$ & $\begin{array}{l}0.0946 \\
0.0817 \\
0.0677 \\
0.0603 \\
0.0533\end{array}$ \\
\hline $\begin{array}{l}17 \\
18 \\
19 \\
20 \\
22\end{array}$ & $\begin{array}{l}0.0538 \\
0.0478 \\
0.0418 \\
0.0359 \\
0.0299\end{array}$ & $\begin{array}{l}0.0478 \\
0.0428 \\
0.0378 \\
0.0324 \\
0.0269\end{array}$ \\
\hline $\begin{array}{l}23 \\
24 \\
26 \\
28 \\
30\end{array}$ & $\begin{array}{l}0.0269 \\
0.0239 \\
0.0179 \\
0.0149 \\
0.0120\end{array}$ & $\begin{array}{l}0.0239 \\
0.0209 \\
0.0159 \\
0.0129 \\
0.0110\end{array}$ \\
\hline
\end{tabular}

(3) Lumber used shall be well seosoned, comr. arcially dry, and free from decoy, loose knots, knots that would interfere with nailing, and other defects that would materially lessen the strength.

(4) Welding and brozing shall be performed in a workmanlike manner using suitable and appiopriate techniq'es, materials and equipment.

(5) Packoging materials and cantents shall be such that there will be no significant chemical or galvanic reaction amang any of the materials in the package.

(6) Closures shall be adequate to prevent inadvertent leakage of the rontents under normal conditions incident to transportation. Casketed closures shall be fitted with goskets of efficient material which will not be deteriorofed by the contents of the contoiner. 
(7) Nails, staples, and other metallic devices shall not protrude into the interior of the outer prockaging in such a manner as to be likely to cause fuilurez.

(8) The noture and thickness of the packaging shall be such that friction during ranspart does not generate any heoting likely to decreose the chemical stability of the contents.

(9) Polyethylene used must be of a type compatible with the lading and must not be permeable to an extent that a hazardous condition could be coused during transportotion and handling.

(d) For specificotion containers, compliunce with the applicable specifications in Parts 178 and 179 of this subchapter shall be required in all details, except as otherwise provided in this subchopter.

(Amct. 173-3, 33 FR 14921, Oct. 4, 1968, as amended by Amdt. 173-11, 34 FP 12589, Aug. 1, 1969; Andt. 173-20, 35 FR 5550, Apr. 3, 1970; Andt. 173-94, 4 I FR 16063, Apr. 15, 1976; Amdt. 173-100, 41 FR 38180, Sept. 9, 1976; Amdt. 173-119, 43 FR 36446, Aug. 17, 1978)

\section{$2.1 \quad$ 178.0-2 APPLICABILITY}

(a) Any person who performs a function prescribed in this fart, shall perform that function in accordance with this part.

(b) When this part requires (either expressly or by reference to 173.24 of this subchapter) a packaging or container to be marked with a DOT specification (for example, DOT-IA, DOT-I7E-304HT, DOT-23C40), compliance with that requirement is the responsibility of the packoging or container monufacturer. Marking the packoging or container with the DOT specification shall be understood to certify complionce by the monufocturer, that the functions performed by the manufacturer, as prescribed in this part, hove been performed in compliance with this part. (See giso 173.28 "Reuse of containers." That section envisions the marking of containers to be performed by a persnn other thon the original manufacturer.) 
(c) Except os specifically provided in 178.337-18 and 178.340-10, the manufacturer of a packoging or container should inform ench person to whom that packoging or container is transferred of any specificotion requirements which have not been met ot time of transfer.

(49 U.S.C. 1803, 1204, 1808 and 49 CFR 1.53(e))

(Amdt. 178-40, 42 FR 2689, Jan. 13, 1977)

\subsection{9 .1 GENERAL}

(a) This Part prescribes the specifications for tanks that are to be mounted on or form part of a tank car and which are used for the tronsportation of hazardus materials in commerce.

(b) Except as provided in paragraph (c) of this section, tanks to w' ich this part is applicable, must be built to the specifications prescribed in this Part.

(c) Tanks built to specifications predating those in this part may continue in use as provided in 173,31 of this subchapter.

(d) Any person who performs o function prescribed in this part, sholl perform that function in accordance with this Part.

(e) When this Port requires a tonk to be marked with a DOT specification (for example, DOT-105A (00W), compliance with that requirement is the responsibility of the tank builder. Marking the tank with the DOT specification shall be understood to certify compliance by the builder that the functions performed by the builder, as prescribed in this Port, have been performed in compliance with this Port.

(f) The tank builder should inform each person to whom that tank is tronsferred of any specification requirements which have not been met at time of transfer.

(Amdt. 179-17, 4I FR 38183, Sept. 9, 1976) 


\section{$3.0 \quad(73.389(j)$}

"Type A pacl-aging" means packaging which is designed in accordance with the general packoging requirements of 173.24 and 173.393, and which is adequate to prevent the ass or dispersal of the radioactive contents and to retain the efficiency of its rodiotion shielding properties if the package is subject to the tests prescribed in 173.398(b). 


\subsection{393 GENERAL PACKAGING AND SHIPMENT REQUIREMENTS}

(a) Untess otherwise specified, all shipments of radionctive materiols must meet all require, ints of this section, and must be packaged as prescribed in 173.391 through 173.396 .

(b) The outside of each packoge must incorporate a feature such os a seal, which is not readily breakable and which, while intact, will be evidence that the packoge hos not been illicitly apened.

(c) The smallest outside dimension of any package must be 4 inches or greater.

(d) Each rodioactive material must be packaged in a packoging which has been designed to mointoin shisiding efficiency and leak tightness, so that, under conditions normally incident to tronsportation, there will be no release of radioactive material. If necessory, additional suitable inside pockaging must be used. Each package must be capable of meeting the standards in 173.398(b) and 173.24.

(1) Internal brocing or cushioning, where used, must be adequate to assure that, under the conditions normally incident to transportation, the distance from the inner container or radioactive material to the outside wall of the packoge remains within the limits for which the package design was bosed, and the radiation dose rate external to the package does not exceed the transport index number shown on the label. Inner shield closures must be positively secured to prevent loss of the contents.

(e) The packaging must be designed, constructed, and looded so that during transport:

(1) The heat generated within the package because of the radioactive moterials present will not, at any time during transportation, affect the efficiency of the package under the conditions normally incident to transportation, and 
(2) The temperoture of the accessible external surfaces of the pockage will not exceed $122^{\circ} \mathrm{F}$. in the shade when fully looded, assuming still air at ambient temperoture. If the pockage is transported in a transport vehicle consigned for the sole use of the consignor, the maximum accessible external surface temperature shall be $180^{\circ} \mathrm{F}$.

(f) Pyrophoric moterials, in addition to the pockaging prescribed in this subpart, must also meet the packaging requirements of 173.134 or 173.154. Pyrophoric radioactive liquids may not be shipped by air.

(g) Liquid radioactive material in Type A quantities must be packaged in or within a leak-resistant and corrosion-resistant inner containment vessel. In addition:

(1) The pockoging must be adequate to prevent loss or dispersol of the rodioactive contents from the inner containment vessel if the packoge were subjected to the 9 meter (30-foot) drop test prescribed in $173.398(\mathrm{c})(2)(\mathrm{i})$; and either

(2) Enough absorbent material must be provided to absorb at least twice the volume of radioactive liquid contents. The absorbent material moy be located outside the radiotion shield only if it can be shown that if the radiooctive liquid contents were token up by the obsorbent material the resultant dose rate at the surface of the pockage would not exceed 1,000 millirem per hour; or

(3) A secondary leak-resistant and corrosion-resistant contoinment vessel must be provided to retain the rodioactive contents under the normal conditions of transport as prescribed in 173.398(b), assuming the foilure of the inner primary containment vessel.

(h) There must be no significont removable radioactive surface contamination on the exterior of the package (see 173.397).

(i) Except for shipments described in paragraph (j) of this section, oll radjoactive materiols must be packaged in suitable packaging (shielded, if necessary) so that at ony time during the normal conditions incident to transportation the radiation dose rote does not exceed 200 millirem per hour of any point on the external surface of the package, and the transport index does not exceed 10. 
(j) Pockages for which the radiotion dose rote exceeds the limits specified in paragraph (i) of this section, but does not exceed ot any time during transportation any of the limits specified in paragraphs (j)(1) through (4) of this section may be transported in a transport vehicle which has been consigned os exclusive use (except aircroft). Specific instructions for maintenance of the exclusive use (sole use) shipment controls must be provided by the shipper to the corrier. Such instructions must be included with the shipping paper information:

(1) 1,000 millirem per hour at 3 feet from the externol surface of the package (closed tronsport vehicle only);

(2) 200 millirem per hour at any point on the external surface of the car or vehicle (closed tronsport vehicle only);

(3) Ten millirem per hour of any point 2 meters (six feet) from the vertical planes projected by the outer laterol surfoce of the car or vehicle; or if the load is transported in an open transport vehicle, at any point 2 meters (six feet) from the vertical planes projected from the outer edges of the vehicle.

(4) 2 millirem per hour in any normally occupied position in the car or vehicle, except that this provision does not apply to private motor carriers.

(k) (Reserved)

(I) Packoges consigned for export are also subject to the regulations of the foreign governments involved in the shipment. See 173.8, 173.9, and 173.393b. (The regulations of the internotional Atomic Energy Agency (IAEA) are used by most foreign governments.)

(m) Prior to the first shupment of ony package, the shipper shall determine by examination or appropriate test that:

(I) The packoging meets the specified quality of design and construction; and

(2) The effectiveness of the shielding and containm. where necessary, the heat transfer charouteristics of the pockage ore within the limits applicable to or specified for the packoge design. 
(n) Prior to each shipment of any package, the shipper sinall insure by examination or oppropriate test that:

(1) The packoge ic proper for the contents to be shipped;

(?) The pockaging is in unimpaired physical condition except for superficial marks;

(3) Eoch closure device of the packoging, including any required gasket, is properly installed and secured and free of defects;

(4) For o fissile material, any moderator and neutron absorber, if required, is present in proper condition;

15) Any special instructions for filling, closing, ond preparotion of the package for shipment have been followed;

(6) Each closure, volve, and any other opening of the containment system through which the rodioactive content might escape is properly closed and seoled;

(7) Eoch package containing liquid in excess of a Type $A$ quantity and destined for air shipment is tested to demonstrate that it is leak tight under an ambient atmospheric pressure differential of at legst 0.5 atmiosphere (absolute)(7.3 p.s.i.a. or $0.5 \mathrm{~kg} . / \mathrm{cm} .{ }^{2}$ ); the test may be conducted on the entire containm ant system or on any receptacle or vessel within the containment system, as appropricte, to determine compliance with the requirement;

(8) If the maximum normal operating pressure of a pockoge is likely to exceed $0.35 \mathrm{~kg} . / \mathrm{cm}^{2}$. (gage), the internol pressure of the containment system will not exceed the design pressure during transportation; and

(9) External rodiation and contamination levels are within the allowable limits.

(o) No ner ion may offer for transportation a package of radioactive materials until the temperature of the packaging system hos reached equilibrium isee also paragraph (e) of this section) unless, for the specific contents, he has ascertained that the maximum applicable surface temperature limits connot be exceeded. 
(p) No person may offer for transportation aboord o passerger carrying aircraft any radioactive material unless that material is intended for use in, or incident to, research, or medical diognosis or treatment, or is excepted under the provisions of 175.10 of this subchapter.

(Amdt. 173-3, 33 FR 14926, Oct. 4, 1968, as amended by Amdt. 173-ó, 34 FR 7162, Moy 1, 1969; Amdt. 173-66, FR 17970, Sept. 21, 1972; Andt. 173-90, 39 FR 45241, Dec. 31, 1974; Amdt. 173-94A, 4I FR 40684, Sept. 20, 1976) 


\section{$5.0 \quad 173.398(b)$}

Stendards for Type A packaging:

(1) Type A pockoging must be so designed and constructed that, if it were subject to the environmental and test conditions prescribed in this paragraph:

(i) There would be no releose of radioactive material from the pockoge;

(ii) The effectiveness of the packaging would not be substontially reduced; and

(iii) There would be no mixture of gases or vopors in the package which could, through ony credible increase of pressure or on explosion, significantly reduce the efrectiveness of the package.

(2) Environmental conditions:

(i) Heat. Direct sunlight at an ambient temperature of $\sqrt{30} \mathrm{~F}$. in still air.

(ii) Cold. An ambient temperature of $-40^{\circ} \mathrm{F}$. in still air and shade.

(iii) Reduced pressure. Ambient atmospheric pressure of 0.5 otmosphere (absolute)(7.3 p.s.i.a.).

(iv) Vibration. Vibration normally incident to transportation.

(3) Test anditions: The packaging shall be subject to all of the following tests unless specificolly exempted therefrom, and also to the consecutive application of at least two of the following tests from which it is not specifically exempted:

(i) Water spray. A water spray heovy enough to keep the entire exposed surfoce of the package except the bottom continuously wet during a period of 30 minutes. Packages for which the outer layer consists entirely of metal, wood, ceramic, or plastic, or combinations thereof, are exempt from the woter sproy test. 
(ii) Free drop. Between $1 / 2$ to $2 t_{2}$ he drs ofter the conclusion of the water sproy test, o free drop through o distance of 4 feet onto a flot essentially unyielding horizontal surface, striking the surfoce in o position for which moximum domage is expected.

(iii) Corner drop. A free drop onto each corner of the pockoge in succession, or in the cose of a cylindrical packoge onto each quarter of each rim, from a height of I foot onto a flat essentially unyielding horizontal surfoce. This test opplies only to packoges which ore constructed primarily of wood or fiberboard, and do not exceed 110 pounds gross weight, and to all Fissile Class II pockagings.

(iv) Penetration. Impact of the hemispherical end of o verticol steel cylinder $1 / 4$ inches in diameter and weighing 13 pounds, dropped from o height of 40 inches onto the exposed surface of the package which is expected to be most wulnercble to puncture. The long axis of the cylinder shall be perpendicular to the pockage surface.

(v) Compression. For packoges not more then 10,000 pounds in weight, $c_{2}$ compressive lood equal to either five times the weight of the pockage or 2 pounds per square inch multiplied by the moximum horizontal cross section of the pockoge, whichever is greoter. The lood shall be applied during a period of 24 hours, uniformly against the top and bottom of the package in the position in which the pockage would normally be tronsported. 